\title{
LIDIANE SOARES RODRIGUES
}

\section{ENTRE A ACADEMIA E O PARTIDO:}

\section{A OBRA DE FLORESTAN FERNANDES (1969/1983)}

Dissertação apresentada ao Departamento de História da Faculdade de Filosofia, Letras e Ciências Humanas da Universidade de São Paulo, sob orientação do Prof. Dr. Ulysses Telles Guariba Netto, para obtenção do título de Mestre em História Social.

São Paulo 


\section{Universidade de São Paulo}

Faculdade de Filosofia, Letras e Ciências Humanas

Departamento de História

Programa de Pós-Graduação em História Social

\section{ENTRE A ACADEMIA E O PARTIDO: \\ A OBRA DE FLORESTAN FERNANDES (1969/1983)}

Lidiane Soares Rodrigues

São Paulo

2006 


\section{Resumo}

Este trabalho consiste na investigação da proposta de intelectual elaborada por Florestan Fernandes, entre os anos de 1969 e 1983 - que marcam, respectivamente, sua aposentadoria compulsória e uma adesão ao diálogo periódico com o grande público, através de sua coluna na grande imprensa escrita. No período, esteve desvinculado tanto da instituição universitária quanto da partidária. Parcela considerável da obra então produzida nasce sob o signo da auto-reflexão - são balanços de sua trajetória intelectual, da Sociologia e dos impasses da formação das ciências sociais no Brasil - e da liberação da coerção discursiva que os campos institucionais promovem. O exame desse conjunto de textos aborda a problemática que é centro gravitacional dos críticos do sociólogo: o equacionamento de sua atuação acadêmica e política. 


\begin{abstract}
This work consists on the study of the intellectual proposition developed by Florestan Fernandes from 1969 to 1983 , which respectively seal his compulsory retirement and is adherence to a periodical dialogue with the public throughout his collum on written press. During this time, he had been out of the universitary institution and the Party aswell. An important parcel of his work ever since produced borns under the sign of a self reflection - it consists on balances about his own intelectual path, Sociology and the difficulties concerning the social sciences formation in Brazil - and the discursive coercion liberation which the institutional fields promote. The examination of this group of texts broaches the set of problems which is the sociologist's main subject studied by his reviewers: the balance between his political and academic performance.
\end{abstract}


Para meus pais 
Há homens que lutam um dia, e são bons; Há outros que lutam um ano, e são melhores; Há aqueles que lutam muitos anos, e são muito bons; Porém há os que lutam toda a vida, Estes são os imprescindiveis. Bertolt Brecht 


\section{$\underline{\text { Agradecimentos }}$}

A pesquisa que originou essa dissertação contou com colaborações inestimáveis. Impossível não manifestar minha gratidão àqueles que me incentivaram ao longo dela. Agradeço inicialmente a Ulysses Telles Guariba Netto, pela orientação segura combinada à ampla liberdade com a qual me permitiu realizar o trabalho, não sem as devidas críticas e o tão necessário estímulo. As sugestões dos professores Gabriel Cohn e Fernando Novais quando da realização do meu exame de qualificação foram valiosas - a eles minha profunda gratidão e admiração.

Para o pesquisador que, jovem demais para compreender as trincheiras das lutas que animaram Florestan Fernandes, não pode se nutrir de sua palavra ainda em vida, debruçar-se sobre sua trajetória é tarefa desafiadora e emocionante. Nos olhos, no sorriso e na memória daqueles que me deram uma palavra sobre o autor, pude sentir as esperanças e apostas de que nossos tempos nos faz órfãos, e às quais sua figura parece dar corpo e alma.

Seria, contudo, impalatável enumerar todos aqueles com os quais estabeleci um construtivo diálogo ao longo da concepção desse trabalho. Alguns, pela presença constante, pela disposição e entusiasmo com o qual me acolheram, e pelas contribuições que me deram, devem ser, entretanto, mencionados. Refiro-me, especialmente, a Lincoln Secco e a Paulo Henrique Martinez - fiéis escudeiros de uma memória dos intelectuais que não anule, mas pressuponha a crítica - que me trouxeram algo daquela expectativa política sob a qual não se formou minha geração. Sou grata a Heloísa Fernandes, Sylvia Gemignani Garcia, Brasílio Sallum pelo auxílio tão bem vindo que conversas informais trouxeram ao trabalho. Gildo Marçal Brandão e Eduardo Kugelmas - desde que cursei famosa disciplina de ambos tornaram-se importantes interlocutores. Agradeço ainda a Sedi Hirano, que na qualidade de diretor da Faculdade de Filosofia, Letras e Ciências Humanas, autorizou minha consulta a documentos da instituição.

Nos múltiplos caminhos percorridos na realização dessa pesquisa tive o privilégio de participar de grupos de estudos que me auxiliaram a aventar novos sentidos a decantadas questões. Sou grata à acolhida do professor Jaime Ginzburg em seu grupo "Literatura, autoritarismo e melancolia"; bem como ao convite dos aguerridos estudantes reunidos para estudar "Fascismo e ditadura" no Departamento de História, para participar de suas leituras. A celebração de uma década do falecimento de Florestan Fernandes promoveu, entre outras coisas, o encontro de pesquisadores de sua obra nos eventos em sua homenagem. As 
acaloradas discussões com esse grupo - especialmente Diogo Valença, Gilcilene de Oliveira Damasceno Barão, Haroldo Ceravolo Sereza - deram fôlego ao último ano dessa pesquisa. Wagner de Melo Romão é especialista com o qual dialogo desde minhas primeiras investigações e a quem manifesto equivalente gratidão.

Afinidades eletivas entre minhas inquietações intelectuais $\mathrm{e}$ as de outros desassossegados estabeleceram vínculos indeléveis entre nós. Distanciamentos promovidos pela necessária solidão do pesquisador não os dissiparam, mas paradoxalmente os intensificaram. Assim, tão distante e tão perto, pude compartilhar meu desassossego com Cristiano Augusto da Silva Jutgla, Jair Diniz Miguel e Jorge Miklos. Assim, os amigos com os quais dividi e multipliquei uma graduação cheia de utopias, como são os tempos carregados do sombrio, também estiveram presentes a cada passo que dei. As cenas da dor e da alegria dos últimos anos se completa com o carinho das amigas Ruth Ladeira e Camila Rodrigues.

Aos de casa, devo algo similar à famosa dedicatória de $A$ integração do negro na sociedade de classes. As palavras são poucas, pois a gratidão nos cala. Espero que vocês encontrem nas páginas que seguem algum motivo para perdoar minhas incontornáveis faltas e falhas.

Por fim, agradeço à Fundação de Amparo à Pesquisa do Estado de São Paulo, pela bolsa de mestrado que a mim foi concedida para a realização desse trabalho. 


\section{ENTRE A ACADEMIA E O PARTIDO: \\ A OBRA DE FLORESTAN FERNANDES (1969/1983)}

Introdução

Capítulo I. Crise: Constructo teórico em fissura (1969-1972)

1. Sociologia e modernidade: o projeto acadêmico político de Florestan Fernandes

2. Golpe militar na Universidade de São Paulo: a aposentadoria compulsória

3. The latin american in residence lectures: primeiras fissuras no scholar

Capítulo II. Perda: Entre o não ainda e o já não mais (1973-1978)

1. A revolução burguesa no Brasil no pensamento de Florestan Fernandes

2. O passado revisitado: entre o não ser mais e o vir a ser

3. Militância solitária e nova esquerda

Capítulo III. Redefinição: Ciência e revolução (1979-1983)

1. Desobediência civil: violação da lei institucional de autonomia

2. Da "gaiola de ouro" à vida pública: aproximação da conjuntura política 


\section{Introducão}

O intelectual ao qual se dedica este estudo é figura das mais diletas de nossa comunidade científica e política. Especialmente entre aqueles que compartilharam das lutas nas quais se envolveu o autor, há sempre uma lembrança saudosa, uma história emblemática a ser contada, algo que sua figura represente fidedignamente. Dentre os que não puderam privar de sua convivência, a deferência não é menor. O carisma de Florestan Fernandes atravessa tempos e espaços. E, se é certo que a dimensão simbólica de seu nome se sobrepõe, por vezes, ao conhecimento de suas reflexões, na base desse fenômeno encontra-se uma impressionante capacidade que parece ter seu nome para "dar voz a um sem número de aspirações de mudança da sociedade brasileira, essa que ele costumava batizar de capitalista selvagem". ${ }^{1} \mathrm{~A}$ compreensão de sua obra não deixa de estar atravessada pelo conteúdo simbólico que se cristalizou em torno de sua figura e, ademais, a excepcionalidade de sua trajetória fomenta essa imagem já sedimentada socialmente.

Voltar o olhar para seu percurso é elucidativo. Não por acaso o cultivo de sua memória se relaciona a vibrantes aspirações sociais. Florestan Fernandes foi artífice da institucionalização da Sociologia em São Paulo, e professor dessa disciplina na Faculdade de Filosofia, Ciências e Letras (FFCL) da Universidade de São Paulo (USP) por quase três décadas. Em 1969, quando a aposentadoria compulsória lhe retirou da Cadeira de Sociologia I, também o tornou, contraditoriamente, órfão de um nicho, do qual foi, a seu modo, o pater. Em sua trajetória ficaria a marca indelével dessa obra, que mescla seu percurso formativo ao da formação da própria instituição. ${ }^{2}$ Posteriormente, lecionou na Universidade de Toronto, até 1972; retomando o papel de docente apenas em 1977, como visitante na Yale University, e como professor titular em cursos de pós-graduação na Pontifícia Universidade Católica de São Paulo (PUC-SP).

Sua trajetória espelha um perfil multifacetado. Esteve junto a diversos ramos da produção cultural, através dos quais estabeleceu um espectro de interlocutores cuja diversidade saliente - intelectuais, estudantes, homens de partido, militantes de diversas causas, adversários e líderes políticos - apreende-se através de relações travadas com o universo menos afeito ao da instituição universitária. Ainda quando este era o eixo de seu circuito intelectual, engajou-se em histórica Campanha pela Escola Pública, bem como na

\footnotetext{
${ }^{1}$ Heloísa Fernandes. "Florestan Fernandes, Universidade e MST”. In.: Caros Amigos, n. 96. São Paulo: Casa Amarela, março, 2005.

${ }^{2}$ Maria Arminda do Nascimento Arruda. Metrópole e cultura. São Paulo no meio do século XX. Bauru: Edusc, 2001.
} 
reforma universitária, já em fins dos anos sessenta. Nos setenta, suas atividades ligaram-se a editoras, entre as quais, destaca-se a coordenação da coleção Grandes Cientistas Sociais, junto à Editora Ática; bem como a direção da coleção Pensamento Socialista, junto à Editora Hucitec. Idealizou ainda as revistas Debate e Crítica e Contexto. Nesses anos, retornaria ao tipo atividade desenvolvida brevemente nos anos quarenta junto aos trotskistas, preterida pelo trabalho no interior da Universidade, de oposicionismo ao regime autoritário, dando contribuições a diversos periódicos - oficiais e "alternativos" - como Leia Livros, Voz da Unidade, Nova Escrita Ensaio, Opinião, Movimento, Senhor, Senzala, Folhetim. A partir de 1983, escreve periodicamente na Folha de S. Paulo. Foi eleito duas vezes como deputado federal, pelo Partido dos Trabalhadores (PT) - ao qual se filiou em 1986, com o intuito precípuo de participar da elaboração da Constituinte. Sua trajetória está marcada, ainda, por notáveis recusas, de empregos no exterior e de dotações de capital estrangeiro, que figuram no mínimo, como significantes do mesmo valor que suas adesões - traço que será motivo de longa reflexão nesse trabalho.

Ademais, o sentido extraordinário desse destino ímpar não fica evidenciado sem que se faça devida menção à sua origem social extremamente humilde e às peripécias através das quais subverteu o destino comum de seus iguais. ${ }^{3}$ Nos extremos de sua vida deve se ligar o engraxate a um dos brasileiros de maior prestígio no interior da plêiade de nossa inteligência. Se considerarmos a complexidade em jogo nos valores socialmente compartilhados diante de trajetórias de ascensão social, que a sua tenha se dado sob o signo da integridade não terá sido de menor relevância - é indubitável que tal traço também responda pelo carisma de sua figura pública.

Aspecto privilegiado para se observar seu prestígio intelectual e seu carisma social é a diversidade de homenagens que tem recebido. Quando a Faculdade de Filosofia, Educação, Ciências Sociais e de Documentação da Universidade Estadual Paulista (UNESP), em 1986, reuniu, sob a coordenação de Maria Ângela D'Incao, inúmeros leitores, amigos, ex-alunos de Florestan Fernandes para comentar sua vida e obra, ficou delimitado um terreno de debates que a decantação pelo tempo não retira a atualidade. ${ }^{4} \mathrm{~A}$ iniciativa se tornou a primeira de inúmeras outras. Quando do término de seu segundo mandato como deputado federal, a homenagem a ele reuniu no antigo edifício da Rua Maria Antonia, a USP, a PUC-SP, o

\footnotetext{
${ }^{3}$ Essa excepcionalidade é tratada por Sylvia Gemignani Garcia, Destino Ímpar. Sobre a formação de Florestan Fernandes. São Paulo: Editora 34, 2002.

${ }^{4}$ Registrado em Maria A. D’Incao (org.). O saber militante. Ensaios sobre Florestan Fernandes. São Paulo: Unesp, 1987.
} 
Parlamento, o Movimento Negro, inúmeros Centros Acadêmicos. Naquele mesmo espaço, tão mágico para os que viveram as experiências históricas heróicas ligadas aos tempos da "Maria Antonia", contribuições valiosas à discussão de sua obra seriam dadas, por ocasião da homenagem prestada em função de seu falecimento. ${ }^{5}$ Muitos eventos lembrariam uma década sem Florestan Fernandes, em 2005. Dentre os quais, ganhou destaque, pelas controvérsias provocadas, a fundação da Escola Nacional Florestan Fernandes, pelo Movimento dos Trabalhadores Sem Terra (MST); e pelo valor simbólico, o batismo da Biblioteca Central da Faculdade de Filosofia, Ciências e Letras (FFLCH) da USP, recém reformada, com seu nome. ${ }^{6}$

Entretanto, a unanimidade desse reconhecimento oculta divergências. No quadro composto pelos temas suscitados por tal percurso, a concordância quanto à incontestável relevância de sua figura está na base da divergência no que se refere ao perfil intelectual que ela representa - o tema consiste mesmo no ponto centrípeto da discussão travada entre seus comentadores. Atravessados pela problemática da inserção institucional e do modelo intelectual promovido por tal vínculo; pela dramática experiência de aposentadoria compulsória, e seus desdobramentos; pelas áreas de estudo com as quais contribuiu; pelas diversas tradições de pensamento com as quais dialogou - os epítetos recebidos por Florestan Fernandes parecem não se esgotar: é um "um mestre perturbador", para Paulo Henrique Martinez, "um educador engajado", para Afrânio Mendes Catani, um "publicista revolucionário", para Paulo Silveira "um militante incansável”, para Antonio Candido, que, com Carlos Guilherme Mota, Miriam Limoeiro Cardoso, e outros, não titubeiam em denominá-lo: de "marxista" - convicção ainda mais inequívoca nas palavras de Aziz Ab'Saber, ao assegurar que "Florestan foi mais intelectual orgânico que o próprio Gramsci." 7 Se essa multiplicidade está marcada por ênfases em aspectos diversos, por enquadramentos distintos e compreensões diferenciadas da trajetória de Florestan Fernandes, também é certo que ela possa ser tributada ao próprio percurso do sociólogo. Trata-se de uma pluralidade de identificações possíveis, no âmbito dos pares no interior da Academia, vínculo inquestionável - e fora dela, vínculo igualmente indubitável. Trânsito de delicada equação, essas duas pertenças não raro se colocam em inescapáveis epítetos binários, de que dá testemunho, as

\footnotetext{
${ }^{5}$ Ver os livros organizados por Paulo H. Martinez, Florestan ou o Sentido das Coisas. São Paulo: Boitempo Editorial, 1998; e por Maria Cecília L. Santos, Maria Antonia: uma rua na contramão. São Paulo: Nobel, 1988.

${ }^{6}$ Antonio Candido, Heloísa Fernandes e José de Souza Martins se manifestaram sobre o nome escolhido pelo MST. Os dois últimos travaram caloroso debate acerca do tema nas páginas da revista Caros Amigos.

7 Sentença feita na mencionada homenagem, prestada por ocasião do término de seu segundo mandato. Os mencionados epítetos encontram-se nas publicações organizadas por Paulo H. Martinez e Maria A. D’Incao, Ver também Antonio Candido, Lembrando Florestan Fernandes. São Paulo: [s.n.], 1996.
} 
denominações de Bárbara Freitag, às quais a fortuna retornaria insistentemente: "acadêmicoreformista" na universidade e "político-revolucionário" fora dela. ${ }^{8}$ Em linhas gerais, a não concordância acerca de como a equação entre esses dois âmbitos se elaborou nessa trajetória está na origem da polêmica instaurada pela autora.

Um estudo que se debruçasse sobre a fração da obra do próprio Florestan Fernandes que pensa esse equacionamento nos pareceu interessante. Além de apreender a teorização própria do autor para o tema que mais mobiliza sua fortuna, esse estudo poderia vislumbrar a historicidade dos diversos perfis a ele atribuídos. E assim, não se proporia a decisão acerca de qual deles teria Florestan Fernandes representado, mas a compreensão do processo pelo qual diversos perfis de intelectual gravitam no eixo de suas elaborações e de seus enfrentamentos das vicissitudes históricas. O fecundo terreno no qual nascem as diversas representações de intelectual conforma, por isso, a problemática que aqui desenvolvemos.

Tendo em vista o eixo institucional que mormente estabelece a linha divisória no percurso do autor, um trabalho que se coloque semelhante tarefa, deve se indagar: qual o potencial heurístico de uma abordagem que se debruce sobre um periodo em que não atuasse organicamente em nenhuma esfera institucional? Uma vez que o sociólogo é primordialmente associado aos anos da institucionalização da Sociologia na FFCL-USP e ao Partido dos Trabalhadores (PT), a lacuna entre esses dois áureos períodos de expressividade pública vulcânica, com centralidade em comprometimentos institucionais, torna-se incômoda. Entre tais anos, 1969 e 1986, Florestan Fernandes vive tempos nebulosos, em tudo distintos daqueles nos quais as mencionadas instituições eram centrais em sua vida pública. Não seria exagero denominá-los de anos de esquecimento. E, bem se sabe, memória e esquecimento são temas da dileção historiográfica.

Como também o são períodos de crise sem precedentes - marcados geralmente por redefinições difíceis, nos âmbitos da vida social ou individual, atingidos pelo desassossego da contingência histórica. Redefinições, não raramente, são embaladas pela dissonante dimensão autoreflexiva dos produtos culturais. Com relação a tal dimensão, já foi afirmado que consiste em elemento intrínseco e necessário à dinâmica do pensamento de Florestan Fernandes. ${ }^{9}$ Decerto, e ela não é aleatória, pois parece intimamente marcada pelo percurso institucional e político do autor. A intensificação dessa reflexão, expressa no pulular de textos cuja problemática central é a condição do intelectual, concentra-se no período imediatamente

\footnotetext{
${ }^{8}$ Ver a publicação organizada por Maria A. D’Incao.

9 Octavio Ianni. “Introdução". In.: Florestan Fernandes: Sociologia. São Paulo: Ática, 1986, p. 30.
} 
posterior à sua aposentadoria compulsória - com fôlego que não se esgota até, pelo menos, sua adesão declarada a um perfil de atuação, o de publicista, que se dá simultaneamente à publicação da "Introdução a Marx/Engels", na seção de História, da coleção Grandes Cientistas Sociais, em 1983. ${ }^{10}$ Indubitavelmente, a concentração do exercício autoreflexivo nesses anos não parece dissociada de uma saída dramática de um circuito institucional, o universitário, e da futura adesão crítica a outro, o partidário.

É possível, assim, adotar a perspectiva de que exista em Florestan Fernandes uma relação constante entre pensamento e ação ${ }^{11}$, que sofre reelaboração diante dos enfrentamentos impostos pela história; e propor a apreensão da historicidade dessa tensão constante, através das formulações do próprio autor, nos anos especialmente desafiantes de seu trajeto. Evidentemente, nesta proposta, há uma mescla dos planos que compõem o pensamento do autor e sua relação com a história: inevitável ao tratar da questão da identidade intelectual, no período assinalado e num autor como Florestan Fernandes - cuja trajetória é ela mesma de uma policronia evidente: a história da Universidade, da Sociologia, a história política, a história intelectual, a história do marxismo no Brasil. No trato de sua reflexão sobre a condição intelectual, o eixo adotado para que a movediça areia não absorva a intenção do estudo, está na relação entre a obra produzida e as condições institucionais de sua produção - âncora na qual as imbricações daqueles diversos planos se manifestam.

Este trabalho concentra-se então entre os anos 1969 e 1983. O primeiro marca a saída traumática de Florestan Fernandes da instituição universitária, promotora de uma crise sem precedentes, através da qual reelabora sua relação com a Sociologia e se vê diante de uma crescente desilusão com relação às promessas que outrora a ela e à sua prática atribuía. Já o segundo, a adoção da prática publicista através do jornal Folha de S. Paulo - núcleo de aglutinação que o levaria ao PT - e a publicação da mencionada Introdução, que sedimentam, num perfil coerente de intelectual, as reflexões gestadas ao longo dos anos a que nos dedicamos.

Há três momentos básicos dos equacionamentos investigados nesse período. Assunto do capítulo inicial, o período imediatamente posterior à aposentadoria é marcado pela recusa de alguns elementos constitutivos de seu constructo acadêmico e pela afirmação de sua identidade política socialista - sem que daí resulte uma proposta de conduta intelectual em

\footnotetext{
10 “Introdução a Marx/Engels". In.: K. Marx - F. Engels: História. São Paulo: Ática, 1983.

${ }^{11}$ Gabriel Cohn. "Padrões e dilemas: o pensamento de Florestan Fernandes". In.: Ricardo Antunes; Reginaldo Moares; Vera Ferrante (orgs.). Inteligência brasileira. São Paulo: Brasiliense, 1986, p. 126.
} 
novos alicerces, mas sinalizando tensões na origem de futuros equacionamentos. A reflexão sobre o tema se manifesta através de comunicações acadêmicas e da avaliação elogiosa da trajetória de Lênin.

Se estas fissuras apontam a falência de alguns suportes anteriores, eles não seriam abandonados por ocasião delas. O rompimento global com esses referenciais seria encetado pelo duplo movimento, por um lado, de ressignificação e instauração de uma memória crítica acerca do passado, no plano da experiência pessoal - e, por outro, o equacionamento sociológico da negação socialista da ordem, que também pressupõe uma visita ao passado, no plano de sua compreensão acerca da modernidade brasileira. Movimento este que se dá com a retomada e conclusão do livro $A$ revolução burguesa no Brasil $^{12}$ e das diversas declarações e entrevistas de teor autobiográfico entre os anos de 1973 e 1978 - objeto de apresentação do segundo capítulo.

Um último momento é marcado pelo desdobramento dos impactos da publicação da mencionada obra, com um retorno à atividade pública constante e a participação em torno dos debates da conjuntura política, através, dentre outras atividades, da docência na PUC-SP, encarada como "desobediência civil"13. A temática em questão se abre para além dos pares usuais, emergindo em entrevistas a jornais alternativos, Compactos $\mathrm{Crí}^{1} \cos ^{14}$, anotações para aulas de curso - adotando a pluralidade dessa interlocução na formulação acerca da identidade intelectual. As conclusões a que chega em A revolução burguesa no Brasil desdobram-se no enquadramento da condição intelectual, cabalmente cristalizada na interpretação da trajetória de Marx e Engels, e em alguma medida incorporada no perfil publicista adotado então - com o que encerramos nosso trabalho.

Um sentido percorre essas etapas. O projeto acadêmico político, elaborado ao longo dos anos de seu circuito institucional universitário, passa por um processo de crise, em que alguns aspectos são modificados, sem configurar uma reestruturação de conjunto; perda, em que referenciais teóricos e institucionais são desarranjados em conjunto, mas ainda não se equacionam em novo edifício teórico; e redefinição, quando então a identidade intelectual é concebida, pelo rearranjo do projeto acadêmico político, numa nova proposta de autonomia, coesa com as nuanças de suas interpretações gerais, em relação à modernidade nacional e ao

\footnotetext{
${ }^{12}$ A revolução burguesa no Brasil. Ensaio de interpretação sociológica. Rio de Janeiro: Zahar, 2a ed. 1976.

${ }^{13}$ Apontamentos sobre a "teoria do autoritarismo". São Paulo: Hucitec, 1979, p. XIX.

${ }^{14}$ Espécie diferenciada de entrevistas, analisadas oportunamente. In.: Brasil: em compasso de espera. Pequenos escritos políticos. São Paulo: Hucitec, 1980.
} 
capitalismo monopolista. A apresentação tem por fim ressaltar a historicidade desse percurso, interna e externamente à obra.

Hodiernamente, os avanços e ramificações da História Cultural, somados à retomada da História Política e ao aval com o qual hoje conta a História Intelectual - impedem que se coloque em dúvida o valor exploratório de uma história que tome como seu, um novo objeto, no qual aqueles eixos da história estejam imbricados. Seria mesmo dispensável, se não fosse tão pródigo, o exemplo da obra de Michel Winock, que o faz com maestria, O século dos intelectuais. ${ }^{15}$

Um olhar de sobrevôo em reflexões relevantes acerca da condição intelectual sinaliza que os que a ela se dedicaram viviam tempos sombrios - sempre particularmente convocativos, daquele traço metacognitivo definidor do intelectual moderno. A tirar pelo século XX tão somente, a delimitação de todo um campo reflexivo origina-se, não raro de derrotas políticas ou culturais, propícias ao (auto) questionamento do sentido da atividade intelectual. Exemplos cabais: Max Weber, diante da modernidade alemã; Karl Mannheim, no entre guerras; Antonio Gramsci e a ascensão do fascismo; Jean-Paul Sartre, Theodor W. Adorno e a Segunda Guerra Mundial. Reflexões desse quilate nem sempre são abrigadas por instituições destinadas à produção do pensamento crítico, que, por vezes no exílio, por vezes nos cárceres, parece questionar a validade de uma crítica que germinasse no amparo de uma inserção institucional cômoda e prestigiada socialmente. Também não parece casual a coincidência entre a intensificação da reflexão acerca dos dilemas últimos da identidade intelectual e a natureza sombria dos momentos assinalados - ao contrário, indica mesmo que a indagação aflita acerca do sentido de sua existência social, política e econômica é parte constituinte da própria identidade intelectual nesses momentos.

Dessa maneira, a proposta aqui lançada pretende colocar em evidência um desses momentos especialmente dramáticos. O enquadramento da questão da identidade intelectual, no período determinado e no autor em questão propicia a apreensão do dilaceramento de todo um espectro cultural - para o qual as expectativas de desenvolvimento democrático e autonomia nacional foram derrubadas por uma modernização acelerada e autoritária, cujo legado é uma sociedade modernizada, contudo "incapaz de dar abrigo firme a valores

\footnotetext{
${ }^{15}$ Michel Winock. O século dos intelectuais. Rio de Janeiro: Bertrand Brasil, 2000. Ver, para o que assinalamos: René Rémond (org.). Por uma história política. São Paulo: FGV, $2^{\mathrm{a}}$ ed., 2003; e Roger Chartier. "Por uma sociologia histórica das práticas culturais". In.: A história cultural. Entre práticas e representações. Lisboa/Rio de Janeiro: Difel/Bertrand Brasil, 1990.
} 
universais". ${ }^{16}$ Para isso, autor e período histórico aqui escolhidos são particularmente profícuos. O exame da experiência de crise histórica, em termos políticos e intelectuais, que aí se configura faz emergirem caracteristicamente os problemas mais contundentes a serem enfrentados pelos que se debruçam sobre as práticas intelectuais modernas, e em particular dos que a ela ligam as expectativas de realização das promessas de emancipação humana da própria modernidade originária.

\footnotetext{
${ }^{16}$ João Manuel Cardoso de Mello e Fernando Novais. "Capitalismo tardio e sociabilidade moderna". In:. Lilia Moritz Schwarcz (org.). História da vida privada no Brasil: contrastes da intimidade contemporânea. São Paulo: Companhia das Letras, 1998, p.637.
} 
Capítulo I

Crise: Constructo teórico em fissura (1969-1972) 
Não pense que esteja triste. As reflexões são tão objetivas quanto as anotações de um curso ou livro. A vida é assim mesmo e só as pessoas muito mediocres vêem suas perspectivas realizadas. É que eu gostaria de ser útil e vejo que o esforço está longe do alvo. Florestan Fernandes 


\section{Sociologia e modernidade: o projeto acadêmico político de Florestan Fernandes.}

Quando, em 1969, Florestan Fernandes foi afastado da Cadeira de Sociologia I, partia com ele um projeto acadêmico político que, tal como sua condição institucional, era inviabilizado face à nova configuração política. Numa proposta que pretenda escandir "certas posturas indicativas de clivagens em relação a postulações correntes nos trabalhos escritos nos anos cinqüenta" ${ }^{17}$, especificamente no atinente à reflexão de seu papel como intelectual, é imperativo que se delimite o terreno a partir do qual elas se processam. Esse é o objetivo precípuo desta seção inicial.

A problemática relacionada à identidade do cientista social mobilizou Florestan Fernandes pelo menos desde os anos iniciais de sua carreira acadêmica. Nesse período, o tema estava atravessado especialmente por questões de ordem metodológica e teórica, tratando da relação do pesquisador com o objeto de estudo, de um ângulo que ressaltava as implicações dessa relação para o âmbito da própria pesquisa - empenho que se liga ao projeto de que ele é figura exemplar, o de organização institucional da atividade científica sociológica. ${ }^{18}$ No interior deste esforço, não se pode dizer que Florestan Fernandes não tenha enfrentado polêmicas. A querela com os folcloristas e o caloroso debate com Guerreiro Ramos ilustram de forma lapidar seus propósitos centrais. Na primeira, ao furtar o tema de autores que o precederam, o sociólogo demarca fronteiras disciplinares e no mesmo passo divide passado e presente, como que dizendo: "a partir deste momento, é impossível escrevermos sobre o Brasil sem levarmos em consideração as formas específicas do conhecimento científico". ${ }^{19}$ Na segunda - em que duelam "concepções opostas" acerca do papel do cientista social, tendo por questão de fundo a "dimensão política da atividade acadêmica" 20 - a defesa da legitimidade de sua concepção universal e racionalista de ciência dá o mesmo recado à tradição, que ainda vicejava no perfil de trabalho impressionista ou muito pouco profissional,

\footnotetext{
${ }^{17}$ Idem, p. 265.

${ }^{18}$ Maria Arminda do Nascimento, Metrópole e cultura, p. 318. São publicações exemplares desse empenho: Ensaios de Sociologia Geral e Aplicada, em 1960; A Etnologia e a sociedade no Brasil. Ensaio sobre aspectos da formação e desenvolvimento das ciências no Brasil, em 1958. Fundamentos empíricos da explicação sociológica, em 1967.

${ }^{19}$ Renato Ortiz. "Notas sobre as ciências sociais no Brasil". Novos Estudos, n.27. São Paulo, julho, 1990, p. 165167.

${ }^{20}$ Gabriel Cohn. "Apresentação". "Florestan Fernandes, história e histórias”. Depoimento a Alfredo Bosi, Carlos Guilherme Mota e Gabriel Cohn. Novos Estudos, n. 42. São Paulo, julho, 1995 (entrevista de 1981), p. 4. Também em: Maria Arminda do Nascimento, Metrópole e cultura, p. 240 e Sylvia Gemignani Garcia, Destino impar, p. 159.
} 
com relação aos parâmetros que tinha por meta instaurar. ${ }^{21}$ Eventos como estes delineiam traços inconfundíveis de sua fisionomia como scholar, e são representativos de seu empenho pela institucionalização da linguagem científica sociológica.

Talvez não se deva afirmar que o debate com Guerreiro Ramos promova um deslocamento na reflexão acerca do papel do cientista social no pensamento de Florestan Fernandes. Contudo, é também em meados dos anos cinqüenta, que o sociólogo paulista passa a tratar mais sistematicamente o tema da identidade dos cientistas sociais do ângulo de suas relações com o conjunto da sociedade. Decerto, é nesse momento que o requisito mínimo para que tal angulação seja possível está preenchido: a conquista do reconhecimento da competência entre os pares e o prestígio social através do domínio de campo do conhecimento, então em vias de rotinização. Adotando como marco de uma segunda fase na carreira acadêmica, com Sylvia Gemignani Garcia, tanto o ano de 1951, quando se iniciam os estudos das relações raciais, quanto 1955, quando se torna regente da Cadeira de Sociologia I e organiza sua equipe de pesquisa, é indubitável: o autor alçava a maturidade como sociólogo - que, no plano institucional se manifesta na conquista de posições na hierarquia acadêmica, com uma orientação para atuação científica em pesquisa e docência, e que, no plano da produção teórica inicia-se com a pesquisa sobre as relações raciais e se dirige à "análise dos padrões de desenvolvimento social e obstáculos à modernização na sociedade brasileira e, metodologicamente a técnicas de pesquisa participante". ${ }^{22}$ As preocupações que ganham saliência orientam o programa de investigação da "escola paulista de sociologia", cuja atenção primeira dirige-se à "explicação sociológica dos dilemas da modernização na sociedade brasileira." Esse empenho por criar uma sociologia do Brasil, desdobra-se do já empreendido, que mirava estabelecer as bases da sociologia no Brasil. ${ }^{23}$

Assim, a questão no centro das ponderações acerca do papel do cientista social se desloca para a delimitação dos contornos de um intelectual moderno, nas condições próprias de uma sociedade cuja modernidade é apreendida segundo sua singular configuração. O perfil moderno de intelectual - aquele que intervém a partir de sua esfera de competência e não apenas defende "seu campo autônomo, regido por valores próprios, mas passa a propor a

\footnotetext{
${ }^{21}$ Ver: Maria Laura Viveiros de Castro Cavalcanti e Luis Rodolfo da Paixão. "Traçando fronteiras: Florestan Fernandes e a marginalização do folclore”. Estudos Históricos. Rio de Janeiro, 1990; Lucia Lippi Oliveira. A sociologia do Guerreiro. Rio de Janeiro: Ed. da UFRJ, 1995.

${ }^{22}$ Destino ímpar, p. 132.

${ }^{23}$ Idem, p. 160.
} 
extensão desses valores para orientar a vida social, política e ética da coletividade" ${ }^{24}$ coloca-se diante de suas próprias considerações acerca da modernidade nacional e traça tarefas para si mesmo em função delas.

Dessa maneira, há uma crescente expansão de sua perspectiva científica racionalista, expressa nos estudos sobre Sociologia Aplicada e planejamento social, que serve de base para a elaboração de um projeto como o Centro de Estudos da Indústria e do Trabalho (Cesit), anexo à Cadeira de Sociologia I, e para a delimitação dos contornos da inserção social da responsabilidade intelectual, cuja sistematização lapidar se encontra na publicação $A$ sociologia numa era de revolução social. ${ }^{25} \mathrm{O}$ que aqui denominamos por projeto acadêmico político consiste na convergência entre a formulação de um ramo intervencionista para a Sociologia, a Sociologia Aplicada, a elaboração do Cesit, e a obra mencionada - conformando uma unidade de sentido em torno dos papéis dos cientistas sociais e da Sociologia. Além disso, sem nos imiscuirmos apressadamente na polêmica que "ciência" e "política" originam quando se trata deste percurso intelectual, aqui a substantivação no "acadêmico" e a adjetivação no "político" sinalizam, apenas, a proeminência dos propósitos científicos, com centralidade na instituição universitária e a crescente coloração política de que tais propósitos são revestidos por conta do curso histórico que deve enfrentar.

Aspecto destacado por Maria Arminda do Nascimento Arruda talvez concorra para o tipo de expansão da orientação científica da Florestan Fernandes. Há algum descompasso entre a conquista do prestígio social alçado pelo domínio do métier e a condição de "especialistas deslocados na dinâmica da sociedade, de intelectuais um tanto marginalizados nas decisões sociais importantes" - desacerto que os coloca em busca "de nichos para atuar", favorecendo a concepção do cientista como "ator, capaz de interferir para promover soluções mais abrangentes", condição análoga à do teórico que inspira o conjunto das formulações, Karl Mannheim ${ }^{26}$, através de sua noção de intelectual flutuante e da perspectiva do planejamento social.

A coesão do projeto fica evidente na apreciação dos estudiosos que se dedicaram a cada um dos elementos levantados. No atinente ao planejamento social e à Sociologia Aplicada, Maria Arminda do Nascimento Arruda assevera que "as perspectivas ligadas ao

\footnotetext{
${ }^{24}$ Idem, p. 14-15. Ver Pierre Bourdieu, "The role of intellectuals in the modern world". Telos, n. 81. Nova York, 1989.

${ }^{25}$ A sociologia numa era de revolução social. São Paulo: Companhia Editora Nacional, 1962; $2^{\text {a }}$ edição reorganizada e ampliada, Rio de Janeiro: Zahar Editores, 1976. (Todas as menções a esta obra referem-se à segunda edição, de 1976).

${ }^{26}$ Metrópole e cultura, p. 247.
} 
planejamento social e ao papel dos intelectuais nesse processo vão ganhando força no fim da década de 1950 e início dos anos 1960, tendo como ponto expressivo a obra $A$ sociologia numa era de revolução social." ${ }^{27} \mathrm{O}$ mesmo sentido é assinalado por Sylvia Gemignani Garcia, que o entende como "momento maior de expansão" da diretriz orientada pela concepção racionalista de ciência. ${ }^{28}$ Quanto ao Cesit, assegura Wagner de Melo Romão que o "projeto de uma sociologia que se relaciona mais diretamente com os problemas sociais do país na intenção de, ao mesmo tempo, aprimorar a compreensão científica da realidade e contribuir para sua solução, terá a possibilidade de concretizar-se com o aparecimento do Cesit". ${ }^{29}$ No tocante à obra $A$ sociologia numa era de revolução social, Tatiana Gomes Martins entende que seja nela que o autor sistematize sua concepção de papel intelectual, o que se deve ao "esforço interpretativo sobre as condições e possibilidades de intervenção do sociólogo no processo de mudança social brasileiro." 30

No que tange à dileção por Karl Mannheim, Gabriel Cohn aponta que "em face do tipo de problema com que desde o início Florestan se debateu - o da intervenção racional na realidade, do planejamento e do controle social - era "mais ou menos natural que Mannheim desempenhasse no seu pensamento um papel importante". Essa adesão "forneceu o equipamento conceitual para levar adiante um trabalho" e "ofereceu as condições para certa autonomia" em relação "às condições institucionais de formação". Assim, é a apropriação de Mannheim, no que tange à elaboração de uma Sociologia Aplicada, que permite detectar problemas de uma ordem social, de modo a "formular condições de intervenção que fizessem frente a esses problemas", procurando "resolvê-los dinamicamente" e "solucionar os pontos de estrangulamento" impeditivos do avanço de "certo padrão que seria precisamente o padrão intrínseco àquele tipo de sociedade" em constituição. Como os problemas sobre os quais se debruçava eram os obstáculos à formação de uma ordem social que comportasse a "possibilidade de uma carreira universal aberta ao mérito", essa vertente teórica resultava num ramo sociológico satisfatório para seus propósitos. ${ }^{31}$

Os três elementos - A sociologia numa era de revolução social, o Cesit e a Sociologia Aplicada - formam uma unidade de sentido na qual se encontram o projeto de modernidade

\footnotetext{
${ }^{27}$ Idem, p. 246.

${ }^{28}$ Destino ímpar, p. 160-161.

${ }^{29}$ A experiência do Cesit: sociologia e politica acadêmica nos anos 1960. São Paulo: USP, Departamento de Sociologia, dissertação de mestrado, 2003, p. 14.

${ }^{30}$ Raízes da sociologia brasileira: Florestan Fernandes e a questão do intelectual. Campinas: Unicamp, Departamento de Sociologia, dissertação de mestrado, 2002, p.34.

31 "Padrões e dilemas; o pensamento de Florestan Fernandes", p.133-136.
} 
para o Brasil, o projeto de ciência para a Sociologia e o projeto de inserção do sociólogo na sociedade, enquanto intelectual moderno. Esta unidade, ao plasmar a orientação geral que é ulteriormente reformulada, é referência constante a que retorna sua reflexão nos anos a que nos dedicamos. A apresentação de suas diretrizes se faz imperiosa.

Wagner Romão, ao se propor o estudo da fundamentação teórica e política do projeto do Cesit, adota essa unidade como objeto privilegiado da análise. Como aponta, no cerne da criação do Centro, a aproximação da ciência à política, "se dava, contraditoriamente, no âmbito de uma alternativa 'antipolítica', em que toda perspectiva prática de atuação deveria ser cientificamente fundamentada". ${ }^{32}$ Assim, "o problema da intervenção" é tratado "no próprio campo da tradição sociológica". ${ }^{33}$

A fundamentação científica da intervenção é relevante, porque não se tratava, apenas, da defesa da intervenção pública do intelectual, mas de abrir o flanco para um ramo específico da Sociologia, a Sociologia Aplicada, de modo que se estabelecessem critérios cientificamente justificados para o uso social das ciências sociais, por isso, "não significa o abandono dos compromissos ligados à produção científica, mas "os pressupõe segundo critérios intrínsecos a esse domínio". ${ }^{34}$ Tal ramo era definido por um conjunto de problemas e objetos específicos. Entre seus problemas estariam aqueles relacionados à mudança social provocada e ao controle racional dessa mudança. Tratava-se de incorporar na teoria "um nível de compreensão da realidade que levasse em conta as variações existentes na própria receptividade das mudanças sociais propostas ao complexo social pelos sociólogos e pelos 'homens de ação'."35 Não há dúvidas quanto à sua tarefa: ampliar o "controle humano dos problemas sociais" $" 36$.

Com efeito, quando Florestan Fernandes elabora teoricamente sua concepção de Sociologia Aplicada, assinala que os conhecimentos teóricos puros são insuficientes para: "estabelecer prognóstico" acerca "do comportamento provável dos elementos e fatores operativos, ao longo do processo de intervenção racional" ${ }^{37}$. Isso porque "a mera inserção de elementos pragmáticos na teoria sociológica é insuficiente para atender às exigências da

\footnotetext{
${ }^{32}$ Wagner de Melo Romão, A experiência do Cesit: sociologia e política acadêmica nos anos 1960, p. 22.

${ }^{33}$ Idem, p. 79.

${ }^{34}$ Maria Arminda do Nascimento Arruda, Metrópole e cultura, p. 246.

${ }^{35}$ Wagner de Melo Romão, A experiência do Cesit: sociologia e política acadêmica nos anos 1960, p. 22.

${ }^{36}$ Idem, p. 19.

37 “A Sociologia Aplicada: seu campo, objeto e principais problemas”. In.: Ensaios de Sociologia Geral e Aplicada. São Paulo: Pioneira, $2^{\mathrm{a}}$ ed. 1971.
} 
intervenção racional"38, é preciso que se tenha "o conhecimento específico das condições de alteração do objeto pela prática", o que é "obtido pela investigação empírica sistemática das situações submetidas a controle racional e a interpretação teórica dos problemas sociológicos que elas colocam ao investigador". ${ }^{39}$ Certamente, o sociólogo "era partidário da idéia, defendia por Karl Mannheim, de que os cientistas sociais precisam alargar sua noção de 'teoria', no sentido de estendê-la à investigação de processos deliberados de intervenção na realidade." 40

A convicção quanto "à ampliação do controle humano dos problemas sociais",41 leva a seus objetos: as sociedades de desenvolvimento "não clássico", que padecem dos descompassos entre a modernização em determinadas esferas e a permanência do tradicional em outras. Assim, se entre seus objetivos, estava o controle da própria mudança social, esta viria a ser contribuição específica dos países "atrasados" à Sociologia, uma vez que estes problemas se colocam de forma contundente neles, mas não nos países que originaram os clássicos da Sociologia.

O impasse, no fundo da proposta, consiste na relação inorgânica entre as instituições e a sociedade. Para ele, "o conhecimento sociológico desempenha, nas nações subdesenvolvidas, a função de equivalente do conhecimento de senso comum" com relação às nações que viveram pioneiramente a experiência moderna, pois "os processos de secularização da cultura e de racionalização dos modos de compreender o mundo não progrediram nem operaram de maneira análoga nas sociedades capitalistas subdesenvolvidas." 42 Por isso, afirma Maria Arminda do Nascimento Arruda, o "problema central para Florestan" consiste em "adequar e refinar os métodos inerentes à perspectiva aplicada da Sociologia a contextos menos orgânicos e mais heterogêneos como o Brasil". ${ }^{3}$

O fundamento, a experiência social na origem da compreensão apresentada, e os desdobramentos resultantes dela são conhecidos. Florestan Fernandes respira a atmosfera política de seus contemporâneos, calcada numa precisa relação com o tempo presente - cuja ênfase "resulta na crença em um futuro promissor identificado, neste caso, com a realidade de

\footnotetext{
${ }^{38}$ Idem, p. 117.

${ }^{39}$ Idem, p. 117.

${ }^{40}$ Wagner de Melo Romão, A experiência do Cesit: sociologia e política acadêmica nos anos 1960, p. 21.

${ }^{41}$ Idem, p. 19.

${ }^{42}$ A sociologia numa era de revolução social, p. 76.

${ }^{43}$ Metrópole e cultura, p. 322. O tema da especificidade de nossa floração moderna é, aliás, simultaneamente, problema sociológico e critério explicativo recorrente entre os cientistas sociais, como atenta Luiz Werneck Vianna, "A institucionalização das ciências sociais e a reforma social; do pensamento social à agenda americana de pesquisa". In.: A revolução passiva. Iberismo e americanismo no Brasil. Rio de Janeiro: Revan, 1997, p. 173.
} 
uma sociedade de classes aberta e com um regime de participação democrática" ${ }^{44}$ - que supõe o tempo pretérito passível de superação. A proclamação de Florestan Fernandes, em 1954, no Congresso Internacional dos Americanistas, evento ligado às comemorações do $I V$ Centenário de São Paulo, é signo das expectativas em jogo com relação ao presente, as quais, indubitavelmente transbordavam da "sensibilidade do cidadão comum permeando as análises realizadas sobre a revolução que se operava na cidade" ${ }^{, 45}$ e pode ser tomada como representativa das apostas do autor no momento: "O passado possui pouca significação. O que importa é o presente e, acima de tudo, o futuro". ${ }^{46}$ Daí uma visão segundo a qual as forças do arcaísmo e da modernidade, que se remetiam, respectivamente ao passado e ao futuro, estavam num confronto no interior da nação - que fazia imperativa certa agenda acadêmico política, na qual o atalho privilegiado para alçar o Brasil ao nível de desenvolvimento dos "países adiantados" era a ciência e a tecnologia científica. ${ }^{47}$

Entende-se dessa forma, que os cientistas se diferenciem do conjunto social por pertencerem à esfera da ciência, secular, racional e moderna, por excelência. Desse estatuto diferenciado resultaria uma competência e uma tarefa igualmente diferenciadas, delimitando uma fisionomia própria à intervenção do cientista social no conjunto da sociedade. Ele é investido de protagonismo, concebido como força vetorial privilegiada que aponta no sentido da modernidade. Para Florestan Fernandes, o sociólogo figura como agente principal na luta contra o "horizonte cultural sufocante". ${ }^{48}$ Pela referida distinção e pela competência creditada ao cientista, de elaboração da síntese que os demais grupos sociais, enraizados em seus interesses particulares, são incapazes de elaborar, ele deve "discernir, no cenário histórico, o que convém e o que não convém ao progresso real da ciência e do padrão correspondente de civilização". ${ }^{49}$

A ciência e o cientista estão, nessa concepção, portanto, acima dos interesses "egoísticos". ${ }^{50}$ As aproximações ao universo intelectual e social de Karl Mannheim se fazem salientes, mesclando a questão da modernização, da mudança social e da possibilidade de síntese atribuída ao cientista social. Como se sabe, no interior do denso debate alemão acerca

\footnotetext{
${ }^{44}$ Maria Arminda do Nascimento Arruda, Metrópole e cultura, p.31.

${ }^{45}$ Idem.

46 "Caracteres rurais e urbanos na formação do desenvolvimento da cidade de São Paulo". In.: Mudanças sociais no Brasil. Aspectos do desenvolvimento da sociedade brasileira. São Paulo: Difel, 1974, 2a ed, p. 201.

${ }^{47}$ Wagner de Melo Romão, A experiência do Cesit: sociologia e politica acadêmica nos anos 1960, p. 8.

${ }^{48}$ A sociologia numa era de revolução social, p. 82.

${ }^{49}$ Idem, p. 62.

${ }^{50}$ Idem, p. 63.
} 
da objetividade do conhecimento ${ }^{51}$, Mannheim foi um dos fundadores da sociologia do conhecimento, ao postular que não há "forma de saber que não expresse situação experienciada na realidade". ${ }^{52}$ Uma vez adotada tal perspectiva, foi preciso "encontrar um correlato na realidade social para a capacidade teórica de elevar-se acima das limitações de uma perspectiva isolada". ${ }^{53}$ A mobilidade social lhe pareceu fazer tal correlação: ao passarem de um contexto socioeconômico a outro, os indivíduos sobrepõem novos a antigos pontos de vista, sendo possível elaborar uma síntese que inclua pontos de vista diversos. A essa "síntese relacional" seria a intelligentsia particularmente sensível, uma vez que os intelectuais freqüentemente abandonam seu contexto social originário para se tornarem cientistas - sendo, portanto, favorecidos por suas trajetórias sociais típicas, na elaboração de uma síntese que abarcasse distintas situações sociais. ${ }^{54}$ Nota-se com isso que, a própria trajetória ascendente de Florestan Fernandes, seu interesse pela mudança social e sua aposta nos cientistas sociais como protagonistas da modernização em geral estão imbricados e encontram, guardadas as devidas diferenças, correspondência na problemática de Karl Mannheim.

Contudo, "acima" dos conflitos particularistas é condição favorável à síntese, mas suscetível a outros conflitos. Ora, enquanto a sociedade é dominada por um horizonte cultural não secularizado, o cientista incorpora o padrão racionalizado; enquanto aquela está cindida em grupos particularistas e com interesses "egoísticos", este estrutura seu pensamento na universalidade da razão. Como resolver o impasse? Prescreve Florestan Fernandes que é a própria ciência quem responde pelo uso social que se deva e possa fazer dela. Para ele, "o fato de pensar cientificamente pressupõe critérios específicos de opção e ação", e, "na medida em que se coloquem os problemas práticos de uma perspectiva científica, a sua contribuição deve corresponder, nos limites do possível, aos caracteres intrínsecos do pensamento científico." 55 Assim, podemos afirmar que dentro desse esquema, a própria ciência é a arma que serve de escudo à exposição social e política a que está submetido o cientista que se propuser o empreendimento da intervenção.

Os conflitos a serem enfrentados não se apresentam apenas no conjunto social. Há, afinal, outras concepções acerca do trabalho intelectual, e o autor pretende se opor a duas formas de isolamento intelectual - o "modo estamental de pensar" e o "pensamento liberal

\footnotetext{
${ }^{51}$ Ver Michael Lowy, As aventuras de Karl Marx contra o Barão de Münchhausen: marxismo e positivismo na Sociologia do conhecimento. São Paulo: Cortez, 1994.

${ }^{52}$ Fritz K. Ringer. O declínio dos mandarins alemães. São Paulo: Edusp, 2000, p. 396.

${ }^{53}$ Idem.

${ }^{54}$ Idem, p. 397.

${ }^{55}$ A sociologia numa era de revolução social, p. 82.
} 
clássico”. Na oposição ao primeiro, encontra-se a recusa ao padrão dos intelectuais letrados da elite nacional, pois “nosso padrão de 'vida literária' foi moldado numa sociedade senhorial”, e o escritor brasileiro compreende-se "à luz de uma concepção estamental de mundo", sustentando a "velha atitude de indiferença das camadas senhoriais perante a miséria material e humana da plebe" ${ }^{56}$. Na oposição ao segundo, a preocupação incide na racionalização da própria absorção do conhecimento sociológico, processo que não poderia se dar segundo o chamado "padrão liberal", no qual a seleção e o aproveitamento das ciências sociais fica a cargo do "acaso". Como "Mannheim já demonstrou, semelhante procedimento caracteriza a mentalidade dominante na era liberal. Depois de produzidos, os conhecimentos sociológicos poderiam ser largados a si próprios. E se possuíssem alguma utilidade, esta se evidenciaria através dos mecanismos societários, pelos quais as descobertas cientificas são convertidas em 'forças' sociais." ${ }^{57}$ A racionalização do aproveitamento do conhecimento sociológico é parte desse projeto, por conta da peculiaridade de uma sociedade em vias de modernização, mas não secularizada. Na dupla recusa assinalada, a finalidade precípua não se faz oculta: o estabelecimento das relações sociais segundo um padrão moderno - numa "dupla adesão à investigação racional da sociedade e ao projeto de racionalização do mundo social" ${ }^{, 58}$, aspecto que o aproxima novamente de Karl Mannheim, que, como ele, procurava opor-se às formas de "antiprogressismo" de seu meio e propor a adesão à modernidade tendo por guia a reta razão. $^{59}$

O compromisso do sociólogo com os imperativos da modernidade estabelece entre seu ofício específico e o conjunto social uma área de interseção na qual coincide o sentido histórico de inserção nacional na civilização ocidental moderna. Assim, a autonomia é garantida pela não vinculação a nenhum grupo particular, seja ele dominante ou dominado. De forma tal, que a ciência norteie a mudança social, acima dos interesses de grupos, sejam eles "os burgueses, os trabalhadores, os partidos, o Estado", considerados míopes, pois pela "ação das ideologias ou dos interesses mesquinhos de classe" perdiam "a oportunidade histórica de promover o equilíbrio democrático entre as camadas sociais no Brasil" ${ }^{60}$ - em outros termos, de tornar institucionalizado o conflito de interesses, que caracteriza a democracia moderna. Se pode ficar sugerido um viés positivista nessas asserções, é válido esclarecer que elas distam dessa vertente, e para tanto, de novo, Karl Mannheim contribui.

\footnotetext{
${ }^{56}$ Idem, p. 226.

57 “A Sociologia Aplicada: seu campo, objeto e principais problemas”, p. 128-129.

${ }^{58}$ Sylvia Gemignani Garcia, Destino impar, p. 28.

${ }^{59}$ Fritz K. Ringer, $O$ declínio dos mandarins alemães, p. 392.

${ }^{60}$ Wagner de Melo Romão, A experiência do Cesit: sociologia e politica acadêmica nos anos 1960, p. 32.
} 
Afinal, tendo seu princípio básico da sociologia do conhecimento no horizonte - o condicionamento dos contextos sociais sobre o saber - não se pode supor que os cientistas não sejam atingidos por eles, mas que, simplesmente, estejam mais equipados para "revelar essa circunstância e tirar as conclusões" necessárias para orientar a síntese de perspectivas. ${ }^{61}$

A coerência de conjunto é salutar. A modernidade, enquanto direção histórica a ser atingida pela nação, atende, em alguma medida, aos interesses de todas as classes; e, no entanto, nenhuma delas é representativa, em seus interesses particulares, dessa mesma modernidade - alcance tributado à ciência, por sua conexão com a racionalização, a secularização e conseqüentemente com o futuro em que apostava. Por isso, para que se trabalhe por ela, não é necessário e nem recomendável que o sociólogo estabeleça vínculos com qualquer classe ou grupo social. E ainda, há, no fundo das formulações, a suposição de que, agindo na direção da modernidade, os resquícios de arcaísmo seriam eliminados registro no mais, pertinente às diversas variações de teses dualistas que marcaram os anos 50 e 60. Muito embora, a evidência de que o sociólogo não estava incólume à predominância, até o início dos anos 60, de uma interpretação da sociedade brasileira pautada pela idéia dos "dois Brasis", inspirada no livro homônimo de Jacques Lambert, não deve sugerir um vínculo direto entre essas formulações e tal obra. ${ }^{62}$ Mas é certo que "diversas variações do dualismo" se traduziam numa aposta, "tácita ou aberta" de que "quer pela via de transformismo societal, quer pela via de um transformismo conduzido por um Estado nacional-popular", haveria "um desfecho democrático da oposição entre o moderno e o atraso". ${ }^{63}$

É esse o tom de $A$ sociologia numa era de revolução social, compilação de artigos ensaios nos quais os sociólogos são convocados a protagonizarem um papel social vinculado ao projeto de inserção do Brasil na "marcha da civilização moderna",64 - justamente por estabelecer aquela área de intersecção favorável à sociologia e à sociedade que legitima a intervenção social do sociólogo como esclarecedor e educador do conjunto social. Para usar termos diletos do autor, a "saturação" dos papéis intelectuais aflora nessas reflexões concorrendo para tanto, suas considerações acerca da modernidade nacional, bem como aquele traço definidor do intelectual moderno, como sujeito que transborda sua esfera de competência ao levar para as outras seus critérios de liberdade e racionalidade.

\footnotetext{
${ }^{61}$ Fritz K. Ringer, O declínio dos mandarins alemães, p. 393.

${ }^{62}$ Wagner de Melo Romão, A experiência do Cesit: sociologia e política acadêmica nos anos 1960, p. 7; Jacques Lambert. Os dois Brasis. Rio de Janeiro: CBPE/INEP/MEC, 1959.

${ }^{63}$ Luiz Werneck Vianna, "A institucionalização das ciências sociais e a reforma social; do pensamento social à agenda americana de pesquisa", p. 204.

${ }^{64}$ A sociologia numa era de revolução social, p. 63.
} 
Essa observação é especialmente pertinente no que tange ao protagonismo do cientista no empenho para o desenvolvimento da própria esfera científica, direção da ação que coincide com o propósito de que as forças da modernidade se expandam. Tal convocação demanda dos cientistas tarefas que extrapolam sua esfera de competência. ${ }^{65}$ Uma vez que a "sociologia não pode medrar onde a ciência é repelida, como forma de explicação das coisas, do homem e da vida"; e possa se desenvolver apenas "entre os povos cuja civilização liberte a inteligência e a consciência do jugo do obscurantismo"66 - em face de um contexto no qual "horizonte cultural predominante é sufocante", e, "o grau de secularização das concepções dominantes revela-se incapaz sequer para harmonizar os dois universos", do leigo e do cientista, "cabe aos cientistas sociais sugerir novos pontos de vista". ${ }^{67}$ Dessa maneira, o "essencial, numa certa fase de suas obrigações perante a ciência e a sociedade, vem a ser a conquista e a defesa de condições materiais e morais do trabalho científico. O combate ao atraso cultural inscrevese entre seus papéis", porque "seu ponto de partida exige que atue como agente de inovação institucional, ao mesmo tempo em que proceda como produtor de uma modalidade do saber científico." ${ }^{68}$ É evidente que o autor não ignora que o "planejamento de instituições de ciência aplicada e o envolvimento institucional dos cientistas em programas de reforma educacional, planos de saúde pública, projetos de reconstrução econômica, etc., dependem naturalmente de oportunidades oferecidas pelo meio social ambiente." ${ }^{69}$ No entanto, vive tempos áureos, nos quais a possibilidade de transcender as debilidades do meio subordina a constatação das dificuldades. Daí, a delimitação da responsabilidade dos cientistas, que "precisam estar alertas diante de todas essas ocorrências para porem suas energias intelectuais e morais a serviço da ciência e da civilização que retira dela as forças que promovem o seu aperfeiçoamento contínuo." 70 Ao se tornarem agentes das "condições morais" - secularização e da racionalização - e das "condições institucionais", são agentes estritos de sua competência específica e o são também da sociedade, legitimamente.

O essencial dessa proposta está em estabelecer a aderência da intervenção à especificidade da competência - fundamento de uma declaração definitiva em 1945: "Cada um com suas armas. A nossa é essa: esclarecer o pensamento e pôr em ordem as idéias" ${ }^{71}$. Ou

\footnotetext{
${ }^{65}$ Idem, p.61.

${ }^{66}$ Idem, p. 62.

${ }^{67}$ Idem, p. 60-61.

${ }^{68}$ Idem, p.62.

${ }^{69}$ Idem, p. 61.

${ }^{70}$ Idem.

${ }^{71}$ Antonio Candido. "Plataforma da nova geração". In.: Textos de intervenção. São Paulo: Duas Cidades/Editora 34, 2002. Identificação que não deve ocultar as distintas formas de realização desse entendimento, cuja célebre
} 
seja, dentro da especificidade do métier, encontra-se já a definido o tipo de intervenção. $\mathrm{O}$ registro aqui é o mesmo de Pierre Bourdieu, que considera falsa a dicotomia entre ciência e política, lançando mão do clássico caso Dreyfus-Zola: atua-se como escritor, intelectual que nutre de força a intervenção através de sua autonomia. ${ }^{72} \mathrm{Ou}$ seja, respeitando a autonomia do seu campo e dentro do seu campo, a atuação pode e deve ser política. Pensando no caso de Florestan Fernandes, notamos que os termos da equação nessas proposições estão em franco casamento amistoso. Nem a ciência se isola do extra-científico, nem é violada por este em seu comprometimento; uma vez que ela é ponta de lança da modernidade - área de intersecção entre ambos.

O fechamento das vias democráticas em 1964 faria entrar em crise aquela "crença em um futuro promissor". ${ }^{73}$ Marcaria mesmo o aborto desse projeto, conforme assinala Wagner de Melo Romão, através do destino do Cesit, cuja proposta indiscutivelmente esmerada nesse perfil intelectual, ilustra a inviabilidade de conjunto do projeto. ${ }^{74}$ Segundo o autor, uma dupla justificativa legitimava o centro: "era preciso produzir conhecimento que explicasse as peculiaridades do desenvolvimento capitalista em países subdesenvolvidos" ${ }^{\text {,75 }}$, o que resultava no "ganho 'científico' das investigações"; por outro lado, era imperativa a opção por temas de pesquisa cuja relevância se colocasse no plano do "próprio desenvolvimento econômico"76, com a finalidade de "suprir os 'homens de ação' de conhecimento que pudesse orientar os rumos do desenvolvimento brasileiro", ${ }^{77}$ Com efeito, "essa segunda justificativa demonstrava o desejo da cadeira em ser formuladora de políticas para o desenvolvimento, o que implicaria, em empresários, sindicatos, etc. É essa posição que fica inviabilizada com o golpe de 1964."78 De fato, o processo suposto na base da formulação do projeto acadêmico político - figurado na expectativa de que se vivia um processo irreversível de modernização que colocaria o Brasil em compasso com as nações de modernidade originária - cedia o cenário histórico à modernidade precária, tão dada à interdição dos ideais que a modernidade idealizada supunha em curso de universalização.

\footnotetext{
oposição, quanto à forma de realizá-lo, pela arte ou pela ciência, em Antonio Candido e Florestan Fernandes, é estudada por Carolina Pulici em De como o sociólogo deve praticar o seu ofício: as cátedras de sociologia da USP entre 1954 e 1969. São Paulo: USP, Departamento de Ciência Política, dissertação de mestrado, 2004.

72 "The role of intellectuals in the modern world", p. 101.

${ }^{73}$ Maria Arminda do Nascimento Arruda, Metrópole e cultura, p.31.

${ }^{74}$ A experiência do Cesit: sociologia e política acadêmica nos anos 1960, p. 93.

${ }^{75}$ Idem.

${ }^{76}$ A sociologia numa era de revolução social, p. 318.

${ }^{77}$ A experiência do Cesit: sociologia e política acadêmica nos anos 1960, p.93.

${ }^{78}$ Idem.
} 
Nos anos imediatamente posteriores à sua aposentadoria compulsória, a vertente intervencionista da sociologia de Florestan Fernandes terá proeminência em sua reflexão acerca dos papéis intelectuais. Não é casual. A interdição de sua condição institucional se coloca pari passu à inviabilidade de suas intervenções. Daí, as reflexões atravessadas pela questão da institucionalidade, tomando-as do ângulo das coerções que ela imprime aos agentes, e valorizando a conduta dissidente com relação a ela. Essa dupla interdição, contudo, se é saliente nas formulações cujo grau mínimo de elaboração se desvela justamente na aderência imediata da reflexão à experiência recém vivida; com o passar dos anos e dos reequacionamentos que as interpretações sofrem, daria lugar ao entendimento da inviabilidade do projeto de forma menos vinculada aos eventos políticos de 1964-1969 e mais imbricada com os dilemas de nossa formação sócio-histórica. Os caminhos percorridos daquela a esta concepção serão a matéria-prima desse trabalho. 


\section{Golpe militar na Universidade de São Paulo: a aposentadoria compulsória.}

Para os que viveram os anos cinqüenta, e gravitavam em torno do espectro políticocultural de esquerda, entre a deflagração do golpe militar e o período mais sombrio de censuras e perseguições pós-1968, um relativo espaço para oposição ao regime autorizava que se prosseguisse o florescimento da década anterior, de modo que a radicalização à esquerda foi vivenciada de modo especialmente intenso. O pulular da produção cultural oposicionista fica evidente mesmo para seus próprios protagonistas históricos. Na denominação de um deles, analista coevo aos acontecimentos, o momento se caracterizava pela "hegemonia política de direita e hegemonia cultural de esquerda". ${ }^{79}$ Além disso, não se pensava que a nova configuração política viesse para ficar. Mas veio e ficou. Para compreender como responde Florestan Fernandes a essa conjuntura política, interessa bosquejar, como o golpe e o regime militar adentram a Universidade de São Paulo. A isso se dedica essa seção.

No capítulo referente às relações entre o sociólogo e a conjuntura política de meados dos anos sessenta, é preciso que se assinale a circunstância de que, se prisões e censura se tornariam mais intensos após de dezembro de 1968, uma vez instaurado, o regime militar, cuidou de seus inimigos no campo cultural imediatamente. Porém, talvez já cuidasse deles, mesmo antes de sua vitória política em 1964.

Dentro de uma linha interpretativa que compreenda o golpe militar como um projeto arquitetado ao longo de anos, pode-se supor que os primeiros contatos de Florestan Fernandes com os futuros protagonistas do regime militar não tenham sido casuais. ${ }^{80}$ Por conta de seu envolvimento com a Campanha pela Escola Pública, o sociólogo era figura pública crescentemente identificada com o setor ligado à defesa dos ideais republicanos, liberais e democráticos, que, em nome da escola pública e laica se opunha aos interesses privatistas e confessionais na educação, em especial ao setor católico. É certo que a unidade simbólica condensada em sua atuação referia-se a um espectro de matizes distintos, composto por figuras como Fernando de Azevedo, Laerte Ramos de Carvalho, Roque Spencer Maciel de Barros, Anísio Teixeira, Paulo Duarte, Júlio Mesquita.

\footnotetext{
${ }^{79}$ Roberto Schwarz. "Cultura e política. 1964-1969”. In.: O pai de família e outros estudos. São Paulo: Paz e Terra, 1978, p. 62.

${ }^{80}$ Perspectiva de René A. Dreifuss, 1964: A conquista do Estado. Rio de Janeiro: Vozes, 1987.
} 
Na reta final da Campanha, o sociólogo seria convidado para dar um curso para os oficiais do Estado Maior do II Exército. A insistência do convite faz com que o esquivo inicial do sociólogo seja vão, e, por fim, o curso se realize com a participação de Fernando Henrique Cardoso e Octavio Ianni. Das seis aulas previstas, Florestan Fernandes seria responsável pela primeira e pela última, cujos temas eram, respectivamente, o papel dos militares na sociedade e os problemas da mudança social no Brasil. O sociólogo foi transportado da Faculdade ao local do curso, pelo Marechal Castelo Branco, e teve entre seus "alunos" o General Costa e Silva.

Seus contatos "intelectuais" com os protagonistas do futuro regime não se esgotariam aí. Alguns meses depois, a iniciativa partiria do sociólogo. Recorrer aos militares seria a "derradeira tentativa", na Campanha - que chegava a seus momentos finais, em razão da força política alcançada pela aliança entre os setores privados, representados por Carlos Lacerda na Câmara dos Deputados. Através de uma solução negociada, foi acordada uma conferência, que Florestan Fernandes daria aos militares. Em relato ulterior, o sociólogo registra sua indignação. $\mathrm{O}$ público conservador a que se dirigia estava muito mais informado e pronto a desafiá-lo, que seus congêneres nacionalistas e esquerdistas, para defender a escola pública. ${ }^{81}$

A aproximação a Florestan Fernandes, evidentemente, pode ser tributada ao interesse dos militares com relação às idéias do sociólogo, com relação à instituição universitária a que se vinculava, e mesmo com relação ao espectro de setores de que era arauto na mencionada Campanha. De qualquer maneira, seja a qual dessas instâncias estivesse dirigida a atenção, o episódio ilustra o caráter menos aberto ao "debate" de idéias, e mais interessado em demarcar condutas políticas, aliados e adversários. ${ }^{82}$

Não é de estranhar que em 1964, a USP já estivesse na mira do novo regime, através da investigação cerrada dos seus mais ilustres frutos de então. Além disso, até esse ano, Gama e Silva, reitor de tendência conservadora, lidava com certa oposição do Conselho Universitário, ligado ao antigo reitor, Ulhôa Cintra. Com a anuência do novo regime ao "marcarthismo" no interior da Universidade ${ }^{83}$, Gama e Silva, atuando então, "na Reitoria

\footnotetext{
${ }^{81}$ A questão da USP. São Paulo: Brasiliense, 1984, p. 89-91.

${ }^{82}$ Convém mencionar que os relatórios da Divisão de Informação do Departamento de Ordem Pública e Social (DOPS) dão indícios de que as atividades de Florestan Fernandes eram muito bem monitoradas. $\mathrm{O}$ acompanhamento remonta à década de 40 , intensifica-se nos anos 60 , e conta com relato quase diário na década de setenta - pois o curso dado no campus da USP em 1979, sobre a revolução cubana contou com um pseudoaluno, cujas anotações podem ser encontradas atualmente no Arquivo do Estado de São Paulo, consultando-se o prontuário de Florestan Fernandes.

83 Tomo emprestado o emprego de "marcarthismo" a Haroldo Ceravolo Sereza, Florestan: a inteligência militante. São Paulo: Boitempo, 2005, p. 147.
} 
como porta-voz da revolução" ${ }^{84}$, sigilosamente, nomeia uma comissão de apuração de "atividades subversivas", cujas conclusões serviriam de material aos Inquéritos Policial Militares (IPMs), junto às Faculdades. A primeira intervenção militar na USP feriria sua comunidade acadêmica através de Fernando Henrique Cardoso, Mário Schenberg e Florestan Fernandes, entre outros. É válido se deter nisso. ${ }^{85}$

Uma vez convocado para o IPM, Florestan Fernandes escreve uma carta denominada "Autodefesa" ao tenente-coronel Bernardo Schonmann, responsável por seu interrogatório. Antonio Candido, Antonio da Rocha Barros, Mário Guimarães Ferri, então diretor da Faculdade, e o próprio tenente-coronel teriam lhe advertido quanto aos perigos daquela atitude - o último alertando-o, inclusive, sobre a possível prisão, caso não a retirasse. A carta não foi retirada. Contudo, as advertências talvez não tenham sido vãs. A elas não se pode dizer que Florestan Fernandes tenha passado incólume. Ao contrário, parecem ter adensado a recusa que ali se ensaiava. ${ }^{86}$ Pois, a disposição à resistência não consistia somente na manutenção da carta, assinalando seu desacordo com uma conduta pautada pela sensatez. A elaboração e a manutenção adquirem sentido político, pela expressão pública que ganham, através de estratagema montado pelo próprio autor.

Antes de ser preso, Florestan Fernandes pede licença para um telefonema familiar e, de sua sala, solicita à secretária que distribua cópias da "Autodefesa" aos estudantes que aguardavam o fim da audiência em frente à diretoria da Faculdade. No dia seguinte, o texto seria publicado nos jornais. Sua prisão origina um transtorno e uma comoção, as aulas são suspensas sem convocação de greve. Após ser libertado, no saguão de entrada da Faculdade, alunos se aglutinam ao seu redor e cantam o hino nacional. ${ }^{87} \mathrm{Se}$, indubitavelmente, o inquérito já consistia num fato político, assim o era por obra do regime militar. Entretanto, a prisão - forjada, exposta e explorada - e o rendimento político daí resultante, transformam o sociólogo em autor de seu fato político. Cela esse sentido, a confissão do próprio tenente

\footnotetext{
${ }^{84}$ Eunice Ribeiro Durham (relatora). O livro negro da USP. O controle ideológico na Universidade. São Paulo: ADUSP, 1978, p. 11. Esse livro consiste no relatório da investigação interna empreendida em 1978, e é fonte básica para $\mathrm{o}$ assunto ainda hoje.

${ }^{85}$ Episódio relevante da conjuntura que precede a aposentadoria de Florestan Fernandes diz respeito à intervenção de Júlio de Mesquita Filho, que pediria ao general Orlando Geisel que o retirasse de quaisquer listas. Trata-se de episódio típico da experiência de liberalismo e paternalismo na história de vida do sociólogo - e é tratado por Sylvia Gemignani Garcia, Destino ímpar, p. 67; Haroldo C. Sereza, Florestan: a inteligência militante, p. 143; e Laurez Cerqueira, Florestan Fernandes: Vida e Obra. São Paulo: Expressão Popular, 2005, p. $92-100$.

${ }^{86}$ A questão da USP, p. 100-101.

${ }^{87}$ Haroldo Ceravolo Sereza, Florestan: a inteligência militante, p. 145-148. Também Eliane Veras Soares, acena o sentido político do fato, mas não explora sua significação (Florestan Fernandes: o militante solitário. São Paulo: Cortez, 1997, p. 70).
} 
coronel à imprensa, segundo a qual, a recusa na retirada da carta foi a razão da prisão. Decerto, "a onda de protestos provocada por esta prisão parece ter contribuído para o encerramento dos IPMs". ${ }^{88}$

Não se esgota com isso o sentido político da atitude. Escandir suas nuanças permite focalizar a experiência social na base de inúmeras reflexões ulteriores. É salutar o argumento central da sua Autodefesa: a autonomia do espaço científico e a violação que os IPMs representam diante dela:

“recebi a convocação para ser inquirido 'policial-militarmente' como uma injúria, que afronta a um tempo o espírito de trabalho universitário e a mentalidade científica, afetando-me, portanto, tanto pessoalmente, quanto na minha condição de membro do corpo de docentes e investigadores da Universidade de São Paulo. Foi com melancólica surpresa que vislumbrei a indiferença da alta administração universitária diante dessa inovação, que estabelece nova tutela sobre a nossa atividade intelectual. Possuímos critérios próprios para a seleção e a promoção do pessoal docente e de pesquisas." ${ }^{89}$

Importa atentar para o sentido social e político da mobilização do argumento da autonomia, pois aqui ele revela seu potencial de denúncia e resistência. Ao se opor à sobreposição da autoridade militar à acadêmica, no interior do espaço institucional próprio da ciência, o autor denuncia o caráter autoritário do novo regime. A defesa da autonomia propicia então que se forje uma resistência com base na legitimidade do exercício intelectual, que não admite a intervenção de outra esfera na sua dinâmica.

É evidente que, pari passu a tal formulação, enuncia-se seu próprio limite. Pois, se o argumento recorre à legitimidade da autoridade rente à esfera de seu exercício - "a ética universitária não nos permitiria converter o ensino em fonte de pregação político ideológica" ${ }^{90}$ - ter por centralidade a defesa da autonomia científica com base institucional, não alcança a defesa da cidadania política. Assim, se pelo lado da autonomia científica, a defesa do perseguido é sustentada - pois, uma vez que ele não leva suas idéias políticas para seu trabalho científico, as outras esferas de poder não podem invadir tal espaço - o argumento não sustenta a defesa da liberdade do indivíduo enquanto sujeito político. $\mathrm{O}$ argumento tende a se desdobrar não na defesa da liberdade política do indivíduo, sendo mesmo a perseguição desta, passível de compreensão, como o faz Paulo Duarte: “Compreendo perfeitamente que, num momento destes, possa a polícia política prender um professor universitário, como o Sr. Mário Schenberg. Este cientista nunca escondeu suas idéias, nunca negou suas convicções e as suas

\footnotetext{
${ }^{88}$ Eunice Ribeiro Durham, O livro negro da USP, p. 25.

89 “Autodefesa". In.: A Sociologia no Brasil. Contribuição para o estudo de sua formação e desenvolvimento. Petrópolis: Vozes, 1977, p. 210. Adoto o sublinhado em citações como grifos meus.

${ }^{90}$ Idem, p. 210.
} 
ligações com o Partido Comunista." ${ }^{91}$ Não se pretende com isso esvaziar o argumento de sua coloração política, porém assinalar que não se elaborou uma resposta à arbitrariedade enquanto princípio político. Para tanto, a diferença de Eunice Ribeiro Durham, ao tomar a defesa da autonomia universitária, referindo-se ao mesmo caso, Mário Schenberg, é expressiva: ele "sempre se declarou abertamente comunista, mas do qual nunca se poderia dizer (...) que lecionasse uma Mecânica (...) de inspiração marxista", contudo: "se existisse tal coisa, seria justo que o lecionasse". 92

De qualquer forma, deve-se notar a íntima ligação entre o episódio e o projeto acadêmico político. Tudo se passa como se este o orientasse e os desdobramentos de sua conduta o ratificassem. Pois entram em curso, num só movimento, dois sentidos, que se remetem à instituição universitária e à conduta política: temos Florestan Fernandes simultaneamente opondo-se ao regime militar e afirmando a autonomia universitária amálgama encontrado em suas formulações. Seu projeto acadêmico político orienta o enfrentamento, na medida em que, ao buscar na autonomia do cientista o pilar de sua defesa e o sentido político de sua atitude, através da mesma conduta pela qual se atém à sua esfera, coloca-se politicamente.

Está em jogo nesse evento, outrossim, o que poderia ser traduzido como dilema e síntese das éticas da convicção e da responsabilidade. Sabe-se o sentido básico de ambas: a ética da convicção orienta a ação por princípios, desprendendo-se das conseqüências dos atos, mormente tributadas às circunstâncias em geral, jamais ao próprio sujeito. Em contrapartida, a ética da responsabilidade subordina o princípio às conseqüências da ação, das quais presta contas o sujeito. Em seus extremos, essas duas éticas são inconciliáveis. Mas também "se completam, e em conjunto, formam o homem autêntico, isto é, um homem que pode aspirar à vocação política." ${ }^{93}$ Ainda que não se leve às últimas conseqüências o termo da vocação política, empregado por Max Weber, é possível se ter no horizonte a dinâmica de ambas dirigindo a ação de Florestan Fernandes, na medida em que a convicção determina a manutenção da carta e assegura a fidelidade aos princípios; enquanto a responsabilidade politiza a ação através da estratégia de exploração política da "Autodefesa" e lhe é garantia do mínimo de danos à segurança pessoal, atendo-se às conseqüências. Não por acaso, a

\footnotetext{
${ }^{91}$ Trecho da carta de Paulo Duarte, publicada em O Estado de S. Paulo, em 15 de maio de 1964. Apud. Eunice Ribeiro Durham, O livro negro da USP, p. 12.

${ }^{92}$ Idem, p. 18.

${ }^{93}$ Max Weber. Ciência e política. Duas vocações. São Paulo: Cultrix, 1967, p. 122.
} 
experiência imediatamente anterior à aposentadoria compulsória se fará sentir na reflexão seguinte, ganhando, a questão da ética, destaque salutar.

O golpe de Estado não estancou "o florescimento cultural diversificado que acompanhou o ascenso do movimento de massas a partir do final dos anos 50"94 -passada a onda inicial de repressão, concentrada nos anos de 1964-1966, há certo afrouxamento da perseguição policial-militar, o que alimenta a oposição, especialmente em seu viés cultural. ${ }^{95}$ Nesse momento, em conjunto ela entende que "o autoritarismo não é senão um retrocesso violento" , decerto passageiro e a curto prazo "condenado ao fracasso", devido a "seu previsível isolamento político e a inevitável estagnação que resultaria da recém implantada política econômica", então subordinada aos interesses "mais retrógrados da elite dominante". 96

Florestan Fernandes não fica ileso ao oxigênio intelectual e político do momento. Seu intenso envolvimento com as expectativas desses anos, contudo, não se expressa em sua produção teórica, ainda que date dessa conjuntura a idéia de uma obra sobre a revolução burguesa no Brasil, mas no envolvimento com a mobilização social pela reforma universitária, verificado, mormente, através dos laços com o Movimento Estudantil. Se escrever em jornais e atuar como personagem pública identificado a causas da educação não eram papéis inéditos, a circunstância histórica de acirramento das oposições propiciava a cada convocação da voz do sociólogo, a produção de um novo fato político - a mencionada transformação da "Autodefesa" em seu acontecimento político parece estar na origem de uma série deles.

Com efeito, as tensões produzidas pelo golpe não arrefeceram o sociólogo. É usual, aliás, que a inegável aproximação de Florestan Fernandes com as causas e os debates mais afeitos ao espaço público de atuação seja assinalada pelo termo "radicalização". 97 Ao que tudo indica, é válida essa denominação, se a entendermos como intensificação das relações entre o sociólogo e a sociedade, fruto da exacerbação, convocada pelas condições históricas e colocada em relevo por sua expressão pública, das elaborações que podem ser localizadas em fins dos anos cinqüenta - mas não de uma mudança de diretriz, ou de conteúdo político, em resposta ao golpe militar. Quando confessa, à época, a sua amiga Bárbara Freitag, seu

\footnotetext{
${ }^{94}$ Marcelo Ridenti. O fantasma da revolução brasileira. São Paulo: Unesp, 1993, p. 75.

${ }^{95}$ Maria Hermínia Tavares de Almeida e Luiz Weiz. "Carro-zero e pau-de-arara: o cotidiano da oposição de classe média ao regime militar". In. SCHWARCZ, Lilia Moritz (org.). História da vida privada no Brasil: contrastes da intimidade contemporânea. São Paulo: Companhia das Letras, 1998, p. 329.

${ }^{96}$ Idem, p. 329.

${ }^{97}$ Como, com nuances, nota-se nos trabalhos de Eliane Soares, Laurez Cerqueira e Haroldo C. Sereza.
} 
envolvimento com as reformas de base, exclusivamente no quesito da reforma universitária e afirma que "r.u. quer dizer, para nós, construção de uma sociedade democrática"98, parece revelar também que essa radicalização desdobra-se de seu projeto acadêmico político.

Ajustado o sentido desse termo denso de ambigüidades, cabe ressaltar que o envolvimento com a reforma universitária ficou registrado em $A$ universidade brasileira: reforma ou revolução ${ }^{99}$ - compilação de uma série de exposições feitas no decorrer de 1968. ${ }^{100}$ Em relato de um contemporâneo, que faz vicejar a experiência histórica, entende-se o sentido conferido ao vínculo com os estudantes, enquanto oposição ao regime recém instaurado. Azis Simão sugere que foi "manifestando oposição à ditadura, com os estudantes na vanguarda, que fizemos uma acidentada travessia para o ano culminante de 1968 ". ${ }^{101}$ Destaca-se, como exemplar testemunho da expressão pública, intra e extra institucionalmente, do envolvimento de Florestan Fernandes com os estudantes, bem como das crescentes dificuldades institucionais que o sociólogo enfrenta, um episódio em especial.

A Congregação da FFCL, em reunião no dia 22/03/1968, foi interrompida por uma invasão estudantil. Florestan Fernandes é então responsabilizado por alguns catedráticos pela ação dos estudantes. O sociólogo teria proposto alteração de pauta para discussão acerca do currículo de Ciências Sociais, a fim de absorver o maior número possível dos excedentes iniciativa que, somada ao seu envolvimento com a causa da democratização do ensino, foi interpretada como possível cooperação com a invasão. Por conta disso, o sociólogo pede demissão de seu cargo de professor, mas é dissuadido e não leva seu pedido adiante. Consta ainda que seu recuo se deva ao fato de que colegas da cadeira de Sociologia I e do Cesit tenham ameaçado pedir demissão coletivamente. É válido notar que a publicidade incomum em acontecimentos que dizem respeito à vida da Congregação de uma Faculdade de Filosofia, ganhando espaço no noticiário da Folha de S. Paulo, expressa a relevância da figura pública de Florestan Fernandes a esta altura. ${ }^{102}$

\footnotetext{
98 Bárbara Freitag. "Florestan Fernandes por ele mesmo". Estudos Avançados, n.26, v. 10. São Paulo, janeiro/abril, 1996, p. 144.

${ }^{99}$ A universidade brasileira: reforma ou revolução? São Paulo: Alfa-Omega, 1975 - cujas extensas notas explicativas indicam a diversidade de interlocutores pelos quais o sociólogo era convocado.

${ }^{100}$ Para seu depoimento sobre o "ano que não acabou", "Florestan Fernandes, história e histórias", p. 16.

${ }^{101}$ Azis Simão. "Na faculdade”. Maria Cecília L. Santos (org.) Maria Antônia: uma rua na contramão, p. 17. A expressão pública, sempre mediada pelo envolvimento com os estudantes, também se faria sentir através dos jornais - de que é salutar exemplo seu artigo publicado, em 31 de março de 1968, nos quatro anos do regime, sobre a morte de Edson Luís. (Ver Haroldo C. Sereza, Florestan: a inteligência militante, p. 150).

${ }^{102}$ Haroldo C. Sereza, Florestan: a inteligência militante, p. 150.
} 
Na reunião seguinte, novos atritos com a Congregação. A querela se estabelece por conta de sua insistência em participar da Comissão Julgadora do concurso para a Cadeira de Política, para a qual era candidato Fernando Henrique Cardoso. Após três votações, seu nome não é escolhido. Sua insatisfação e decisão de não mais comparecer às reuniões da Congregação são registradas em ata. O sociólogo só voltaria à Congregação, por ocasião da ocupação do prédio da Faculdade pelos estudantes.

Esses são capítulos da difícil relação de Florestan Fernandes com a instituição universitária, cujas origens remontam pelo menos ao início dos anos 60, quando o sociólogo "tenta impor sua influência, seu estilo de trabalho, e sua concepção sobre o papel social do intelectual para além das fronteiras da cadeira de Sociologia I". ${ }^{103}$ Desestabilizavam as relações de poder no interior da FFCL-USP, indubitavelmente, a firme concepção de trabalho científico, aliada a uma vigorosa política interna de formação e elaboração de um grupo coeso, beneficiada pelas condições galgadas intra e extra institucionalmente pelo grupo que gravitava em torno da Cadeira de Sociologia I, personificado em Florestan Fernandes - sendo particularmente representativos disso, a criação da Fapesp e o projeto do Cesit. ${ }^{104}$ Os eventos mencionados parecem sugerir que, paralelamente ao envolvimento extra-institucional, as já problemáticas relações políticas intra-institucionais tornavam-se mais delicadas para o catedrático, na medida em que os vínculos externos levavam água ao moinho dos conflitos internos. Outrossim, são também indicativos da problemática relação entre Universidade e história política recente: no interior da instituição, amalgamam-se os fatores estritamente políticos aos estritamente acadêmicos, e, por vezes, esses subordinam aqueles.

Esta mescla é decisiva no episódio das aposentadorias compulsórias. A dinâmica que as preside possui dimensão política interna e externa à instituição universitária. Eunice Ribeiro Durham, em sua análise da primeira lista de professores "subversivos", afirma que "fica patente que as acusações não englobam todos os professores considerados, na USP, como sendo 'de esquerda'. Inclui, por outro lado, muitos que nunca o foram." Tendo em vista que a lista "certamente, consegue atingir todos os grupos que poderiam ser considerados como os mais inovadores e aqueles que apoiavam a gestão Ulhôa-Cintra", conclui a autora que, no conjunto, "a denúncia procura destruir a influência intelectual de alguns dos

\footnotetext{
${ }^{103}$ Wagner de Melo Romão, A experiência do Cesit: sociologia e política acadêmica nos anos 1960, p. 87.

${ }^{104}$ Idem, p. 85-89. Ver também Carolina Pulici, De como o sociólogo deve praticar o seu oficio: as cátedras de sociologia da USP entre 1954 e 1969.
} 
professores e cientistas mais brilhantes da Universidade". ${ }^{105}$ Se, por um lado, os professores aposentados apresentavam em conjunto alguma orientação mais à esquerda, ainda que não necessariamente, o certo é que disputavam posições de poder e prestígio no interior da instituição e pertenciam a grupos que alçavam a vitória nessa disputa. Adotando-se essa perspectiva, entende-se que a combinação entre fatores políticos e acadêmicos fez com que os segundos explorassem os primeiros, que se transformaram em mais uma das armas de que se valem, em condições normais, legitimamente, os agentes, na disputa por poder e prestígio no interior da instituição. Entretanto, a disputa que se valeu de tais armas tomaria proporções nunca antes atingidas e resultaria em conseqüências nunca antes aventadas, as aposentadorias compulsórias, em 1969.

Haveria ainda um momento dramático para a comunidade acadêmica da FFCL-USP, que as antecede, a chamada "Guerra da Maria Antonia". Em outubro de 1968, o prédio da Faculdade foi, com conivência das tropas chamadas para conter o conflito entre os estudantes da USP e do Mackenzie, invadido, bombardeado e incendiado. Florestan Fernandes desabafa: "Fiquei furioso. Mas nada pude fazer - nem posso, nem poderei. O remédio não está em responder ódio com ódio. Mas, em corrigir a sociedade brasileira. O que é difícil (...) A luta atual está entre o meio fascismo (o fascismo disfarçado existente) e o fascismo declarado, que a extrema direita que impor ao país."

Seria pueril cobrar precisão conceitual do autor em um texto de natureza epistolar. Contudo, talvez justamente por isso seja factível encontrar na caracterização -“meio fascismo" e "fascismo declarado" 107 - a vivência típica de época, para a qual, o acirramento de posições à esquerda e à direita, fazia com que ambas as partes extremasse a posição da outra. Assim, a mesma disposição que dirige a radicalização parece nutrir a percepção de seus limites. É saliente certo recuo melancólico do confronto aguerrido forjado pelo sociólogo com o regime militar. Recuo este, marcado explicitamente por essa visão de extremos, que seria ratificada pela recepção do AI-5. O regime é então percebido no avesso daquela transitoriedade que marcara seus anos iniciais, o ato instaura um sentimento de permanência do regime autoritário. E marca "o fim de um florescimento cultural correspondente ao

\footnotetext{
${ }^{105}$ Eunice Ribeiro Durham, O livro negro da USP, p. 19. Outros indícios, ligados aos eventos ocorridos na Faculdade de Medicina, confirmam essa interpretação. Idem, p. 27.

${ }^{106}$ Bárbara Freitag, "Florestan Fernandes por ele mesmo", p. 144. A carta data de 04/11/1968.

107 Milton Lahuerta faz interessante apanhado das diversas "reações" ao golpe militar no meio intelectual universitário, em termos de diagnóstico da conjuntura e opções políticas daí resultantes. Intelectuais e transição: entre a política e a profissão. São Paulo: USP, Departamento de Ciência Política, tese de doutorado, 1999, p. 79125.
} 
movimento popular que tivera seu ápice em 1963 e início de 1964, e que ainda se manifestaria esporadicamente até o final da década, especialmente em 1968". ${ }^{108}$

Não se pode dizer que na noite de 27 de abril de 1969, quando as aposentadorias foram anunciadas, houvesse muita surpresa entre aqueles que a sofreram. A intervenção de poder externo à Universidade não era novidade. Atestam-no, por exemplo, os problemas para contratação de professores. Jânio Quadros, Florestan Fernandes e Mário Schenberg, protagonizaram, na qualidade de governador de São Paulo e catedráticos das Cadeiras de Sociologia I e Física, uma controvérsia em torno da contratação de Marialice Foracchi e César Lattes - negadas pelo governador. No caso da Sociologia, Florestan Fernandes redigiu extenso "Relatório sobre a situação do ensino das Ciências Sociais na USP", que seria encaminhado ao governador e publicado em O Estado de S. Paulo. ${ }^{109} \mathrm{O}$ caso de Mário Schenberg anunciava com antecedência o impalatável respaldo que intervenções externas encontrariam internamente na instituição. A Congregação FFCL defendeu seu catedrático, mas o Conselho Universitário da USP concordou em censurar Mário Schenberg pela crítica feita publicamente a Jânio Quadros. ${ }^{110}$ Também a "Comissão sigilosa" de Gama e Silva, já do conhecimento público, dava testemunho de que a intervenção externa à Universidade parecia tornar-se comum. Além disso, o acirramento de posições tornava a instituição particularmente sensível à conjuntura política.

Entretanto, a ditadura militar representava um enfrentamento com o poder externo e uma afronta à autonomia universitária sem precedentes. Em "1964 foi diferente - e o desmoronar do mundo lá fora apanhou a Maria Antônia despreparada para o contato físico com o poder nu". Naquela noite, o esperado mas indesejado não surpreendeu. Porém, não estavam os professores preparados para ela. E, no entanto, ela trazia o apanhar violento do golpe, sentido em sua perversa "plenitude", com o "drama do AI-5", com o "drama de 1969 ". ${ }^{111}$

"Florestan Fernandes", foi um nome que constou em todas as listas que elencaram as atividades "subversivas" na universidade. Acusado pela "Comissão sigilosa", foi apreendido pelo IPM e preso. Esteve no primeiro decreto das aposentadorias - em que o Governo Federal aposentava funcionários estaduais. E por fim, o segundo decreto,

\footnotetext{
${ }^{108}$ Marcelo Ridenti, O fantasma da revolução brasileira, p. 80.

109 Publicado em A Sociologia no Brasil.

${ }^{110}$ Wagner de Melo Romão, A experiência do Cesit: sociologia e politica acadêmica nos anos 1960, p. 58-62.

${ }^{111}$ Oliveiros S. Ferreira. "Maria Antônia começou na praça". In.: Maria Cecília L. Santos (org.) Maria Antônia: uma rua na contramão, p. 25.
} 
"corrigido" e dirigido especificamente à USP, o retirou de sua Cadeira, aposentando-o compulsoriamente junto com o reitor em exercício, Hélio Loureço de Oliveira, e mais vinte e três professores. ${ }^{112}$

Do ponto de vista de sua carreira, a aposentaria compulsória implicaria numa experiência inédita até então: lecionar numa Universidade estrangeira. Se já havia sido um visiting scholar na Columbia University, do último semestre de 1965 a janeiro de 1966, e participado de diversos compromissos acadêmicos no exterior, a docência no estrangeiro, como atividade sistemática, cuja finalidade fosse o suprimento financeiro, era-lhe algo novo. Mas os "resultados nefastos" da aposentadoria - "perda súbita de parte substancial da renda; necessidade de acumular alguns trabalhos remunerados de natureza intelectual; premência de sair do Brasil (pois o artigo 3 do ato institucional n. 10 fecha-nos as portas do ensino, da pesquisa e da tecnologia)" 113 - impuseram o desafio. Assim, no período imediatamente posterior à aposentadoria compulsória, o sociólogo, deixando esposa e filhos na pátria-mãe, parte para o Canadá, como um latin american in residence. Ele se tornaria, em 1970, professor titular da Universidade de Toronto. Entretanto, em fins de 1972, pediria demissão para retornar ao Brasil, deixando as vantagens conquistadas naquela instituição. Voltaria a lecionar apenas em 1976 e 1977, como docente de cursos de extensão cultural no Instituto Sedes Sapientiae e nos cursos de pós-graduação da PUC-SP.

Há múltiplas dimensões nos desdobramentos de sua aposentadoria. Em larga medida, a profunda tristeza, que se faz presente por longos anos no discurso sobre o passado, é signo do trauma da saída involuntária do centro no qual vicejavam suas expectativas. Por isso, ainda que a dimensão psíquica desses processos não seja a prioridade desse trabalho convém reconhecê-la. Mesmo porque, a subseqüente condição de estrangeiro tornaria a experiência paradoxalmente mais dramática. Como assinala Heloísa Fernandes, em reflexão sobre o exílio, elaborada a partir de material epistolar de seus pais, o exílio é substancialmente distinto da emigração, por conta da relação estabelecida entre o sujeito e os espaços de abandono e adoção - "o emigrante viaja nos braços de um desejo em relação ao seu lugar de destino. O exilado carrega uma sentença de expulsão, forçada ou voluntária, da sua terra" 114 - e os tempos a que se referem tais espaços - "o emigrante quer ser aceito e reconhecido, ele é movido por um desejo de futuro. O exilado é o

\footnotetext{
${ }^{112}$ Eunice Ribeiro Durham, O livro negro da USP, p. 39-49.

113 Bárbara Freitag, "Florestan Fernandes por ele mesmo”, p. 146-147.

${ }^{114}$ Heloísa Fernandes. "Chaves do exílio e portas da esperança". São Paulo: s.n., 2005, p. 5. (Gentilmente cedido pela autora).
} 
desterrado, o retirante imerso no trabalho do luto da sua querência, condenado a carregar, nas cores da saudade, um passado que recusa abandonar."115 Com efeito, não fincaria raízes na terra para a qual se dirigia. Ademais, o sentimento de desterro em sua própria terra, traço que bem caracteriza o intelectual brasileiro ${ }^{116}$, se toma o coração de Florestan Fernandes através dos desencontros entre seu projeto e as possibilidades históricas de realizá-lo, não é equacionado satisfatoriamente por uma adesão ao cosmopolitismo ou pela contraposição de uma "visão negativista da situação nacional à consideração positiva das condições de vida e de trabalho no circuito dos países centrais da civilização moderna". ${ }^{117}$

No tocante à centralidade desse trabalho - o perscrutínio das vicissitudes que atravessam a reflexão sobre os papéis do intelectual na obra de Florestan Fernandes - o intérprete não pode obnubilar a evidência de que, se o percurso formativo do autor, inclusive no âmbito da constituição de si mesmo e de sua identidade social, é indissociável da formação da própria institucionalização de sua disciplina, a saída desse nicho institucional terá significação equivalente, no que se refira à reconstituição de si mesmo, ao estabelecimento de uma nova relação com a disciplina e de uma nova equação do sentido social e político de sua própria atividade.

Há, entretanto, sensível lacuna de material para reconstituição do período em que leciona no Canadá. ${ }^{118}$ Lacuna que contrasta, contudo, com as muitas discussões acerca das imbricações entre trajetória, obra e posições políticas de Florestan Fernandes e o golpe militar de 1964. Este trabalho deverá enfrentar as sutis nuanças que caracterizam esse debate, e elas emergirão de diversos ângulos ao longo dele. Por isso, é preciso que se trace o terreno no qual ele se finca, bem como o perfil intelectual que a visão dessa relação fomenta entre os comentadores.

Quando Bárbara Freitag, em 1986, dividiu sua trajetória em uma "fase acadêmicoreformista" e outra, "político-revolucionária", apontando como divisor de águas para ambas, a aposentadoria compulsória, estabeleceu um debate - saliente no fato de que, durante o próprio

\footnotetext{
115 Idem.

${ }^{116}$ Como gosta de nos lembrar em aula a professora Maria Arminda do Nascimento Arruda.

${ }^{117}$ Sylvia Gemignani Garcia, Destino impar, p. 21.

${ }^{118}$ A dificuldade, no que se refere à reconstituição factual de sua estadia no Canadá, deve-se à exigüidade de documentos disponíveis. Conta-se apenas com suas notas explicativas, prefácios, o material epistolar publicado por Bárbara Freitag, as poucas referências que faz ao período em seus depoimentos, e com as mínimas referências que se extrai da fortuna crítica. Seu arquivo pessoal completo se encontra nas Coleções Especiais da Biblioteca Comunitária da Universidade Federal de São Carlos (UFSCar). Até a conclusão desse texto, a parte do acervo que poderia sanar essa lacuna, não pôde ser consultada. A despeito disso, o encaminhamento do tipo de reflexão aqui proposta pode ser realizado.
} 
evento, inúmeros outros palestrantes se remetessem à sua periodização. A autora entende que, atuando na Universidade, o papel da Sociologia era o de um instrumental analítico que possibilitasse o controle da mudança social; após o golpe, aponta o abandono do paradigma científico anterior, dos problemas teórico-metodológicos da Antropologia e das minorias étnicas; a adoção do paradigma marxista, dos estudos políticos e da crítica à realidade brasileira, em textos com teor de manifesto. ${ }^{119}$ Opondo-se, reafirmando-a, ou tomando-a como ponto de partida, os autores a ela se remetem, sedimentando mesmo uma marca com a qual todo intérprete depara-se no percurso de seu estudo. Ter sido uma das primeiras a se colocar em relação à inescapável questão de denominar perfis intelectuais significativos como o de Florestan Fernandes parece ter contribuído para isso. Também concorre para tal o fato de que o evento consista num primeiro esforço de balanço sobre vida e obra do autor - contando, portanto como o mínimo de reflexão acumulada nesse momento. Deve-se ainda considerar o contexto dessa afirmação - vésperas da filiação do autor ao PT - pois, a despeito dos posicionamentos críticos do autor e de sua entrada muito refletida e crítica no PT, forja-se socialmente a identificação, e não a crítica, de sua figura à do Partido.

A complexidade envolvida na resposta a uma colocação em termos dicotômicos, como é o caso, joga papel decisivo no debate por ela instaurado. Buscam-se outros "marcos", através de outros ângulos, na tentativa de, pela "flexibilização" destes, escapar à dicotomia do esquema, e, decerto, nesse movimento dos interlocutores a questão das linhas divisórias e da relação com o golpe militar de 1964 enquanto eixo para ruptura ou continuidade num determinado perfil de intelectual, são repostos. Outrossim, o debate faz multiplicar os epítetos identificadores do perfil intelectual de Florestan Fernandes, o que nem sempre colabora para a efetiva compreensão da trajetória do autor, revelando antes, as distintas compreensões do que seja atuação política, marxismo, engajamento, comprometimento social, etc. Além disso, não raramente, a defesa de um ou outro perfil está alicerçada em citações descontextualizadas da problemática em que se origina no interior da obra do autor - procedimento equivocado quando se tem por intuito precípuo compreendê-la.

O enfrentamento está posto a todo intérprete da obra em questão. Os encaminhamentos divergem. Para a problemática que nos propomos a desenvolver, contudo, seria estéril se deter na questão do termo mais adequado ou da periodização mais precisa que dê conta do perfil intelectual do sociólogo - pois, inegavelmente há evidências de toda natureza para que se defenda as inúmeras identidades a ele atribuídas. Seria também

\footnotetext{
119 “Democratização, universidade, revolução". In.: Maria A. D’Incao (org.). O saber militante, p. 164-169.
} 
imprudente e de mau gosto contrapor às interpretações, trechos distintos de citações, estabelecendo um duelo infindável entre elas. Sobretudo, seria desaconselhável para um historiador, não primar pela especificidade de seu métier no empenho por sua contribuição.

Nesse sentido, temos o dever de sinalizar algumas imbricações latentes. Dentre os inúmeros procedimentos para se opor à perspectiva de Bárbara Freitag, é possível identificar a eliminação mesma da linha divisória que a origina, apagando o golpe militar do horizonte de compreensão da trajetória. Com isso, fica estabelecida uma memória que se forja pelo esquecimento de um fato reconhecidamente indelével no percurso do autor. Elabora-se mesmo um mito de origem, pelo qual ele seja sempre o mesmo e, através do tempo, a historicidade não se manifeste, mas se reproduza um padrão de pensamento e ação. Por sua vez, localizar na aposentadoria compulsória o marco de uma suposta radicalização à esquerda de Florestan Fernandes instaura inegavelmente um mito de ruptura, celando a trajetória em "antes" e "depois". ${ }^{120}$ Tanto um quanto outro procedimento, ao instaurarem os respectivos mitos, opõe-se ao trabalho historiográfico, cuja preocupação se dirige à historicidade na raiz tanto de um, quanto de outro. Por isso, é preciso encontrar uma alternativa, tanto à mencionada dicotomia cujo eixo instaura um mito, quanto à eliminação do evento político, que instaura outro.

Essa problemática envolve também a questão da memória intelectual. E, embora não possamos explorar o problema a fundo, acená-lo é relevante para indicar nossa perspectiva. É certo que História e Memória estão numa zona fronteiriça de difícil delimitação. Mas é certo também que a mínima distinção entre ambas, faz-se mister no trabalho historiográfico. De fato, há pelo menos duas tarefas do historiador relacionadas a essa questão: no dizer conhecido de Eric Hobsbawm, "lembrar o que os outros esquecem""121; e no de David Lowenthal, "produzir uma memória diferenciada". ${ }^{122}$ Ao realçar um momento pouco áureo do percurso do autor; e ao embasar os argumentos numa apreensão contextualizada interna e externamente à obra, respectivamente, a recomendação de Hobsbawm e a idéia de memória diferenciada orientam a análise. Em suma, por estas razões, o escopo desse trabalho busca uma dimensão capital na qual a aposentadoria compulsória se faz presente, sem que instaure o mencionado mito de ruptura, e na qual a continuidade se faz sentir sem que se apague o

\footnotetext{
${ }^{120}$ Agradeço ao professor Marcos Napolitano a observação desses dois "mitos".

${ }^{121}$ Eric Hobsbawm. A era dos extremos. São Paulo: Companhia das Letras, 1995, p. 13.

${ }^{122}$ David Lowenthal. "Como conhecemos o passado". Projeto História. Trabalhos da Memória. Revista do Programa de Estudos Pós-Graduados em História e do Departamento de História. PUC-SP. São Paulo, n. 17, novembro de 1998, p. 146.
} 
evento político, como no mito de origem. É certo que a assinalada multiplicidade de perfis intelectuais se deva à trajetória em tela, mas a multiplicação indefinida deles, não.

Além da centralidade de sua aposentadoria, as relações entre a obra e condições institucionais de sua produção parecem orientar as preocupações de seus comentadores e também marcar a convergência da discussão para o tema de seu perfil intelectual. Por isso, ao perscrutarmos o exercício de reflexão sobre o próprio papel enquanto intelectual, temos em vista a historicidade da reflexão do autor, a partir do terreno delineado para as tarefas dos intelectuais modernos em sociedades periféricas, cerne de seu projeto acadêmico político. Nossa proposta salienta a mesma problemática enfrentada com vigor pelos comentadores, procurando colocar em evidência os impasses do próprio autor, em seu empenho por equacionar sua identidade intelectual e política. Ao longo desses anos, a historicidade das condutas intelectuais idealizadas pelo autor é indissociável das nuanças em sua interpretação do Brasil, de sua relação com a ciência e com o meio acadêmico, e da relação com seu próprio passado. Com isso, a produção intelectual e as condições institucionais de sua produção são enquadradas duplamente: ao tomarmos um período no qual o autor se mantém afastado das instituições, e ao colocar em juízo sua própria teorização acerca dos limites e possibilidades do intelectual ligada à instituição, universitária ou partidária.

O movimento de autoquestionamento identitário é próprio daquele espectro da esquerda político-cultural, no interior da qual esta seção localizou o autor. Para os que estiveram envolvidos em movimentos políticos e sociais, ou partidos e instituições, às vésperas do golpe militar, os dilemas teóricos e políticos eram atravessados pela derradeira indagação: "por que fomos derrotados?" Questão que não seria respondida sem uma autocrítica pungente e o questionamento daí decorrente quanto ao próprio papel no contexto político. Não serão escassas as acusações mútuas, entre as vertentes derrotadas, e é certo que o momento imediatamente pós-1964, é marcado pela desorientação típica de tempos em que à urgência de respostas não correspondem as oportunidades de sua elaboração. ${ }^{123}$

Em Florestan Fernandes, a reflexão acerca do próprio papel é dimensão permanente do trabalho intelectual - traço que não escapa aos observadores, e que leva Carlos Guilherme Mota a afirmar que não há "outro cientista social ou escritor tenha refletido tanto e tão compulsivamente sobre seu próprio papel institucional e político e sobre a significância de

\footnotetext{
${ }^{123}$ Ver Daniel Pécaut, Os intelectuais e a política no Brasil. Entre o povo e a nação. São Paulo: Ática, 1990, p. 200-201.
} 
sua disciplina". ${ }^{124}$ Contudo, se é fácil entrever que "Florestan é, desde os seus primeiros livros, um autor reflexivo" 125 , a persistência talvez se deva, como quer Octavio Ianni, ao fato de que essa não seja mais uma entre tantas, mas a dimensão constituinte de seu pensamento. Pois, se "o pensamento se pensa o tempo todo" $" 126$, é porque é próprio de sua dinâmica "a reflexão crítica sobre as condições e implicações da produção intelectual". ${ }^{127}$ No entanto, essa constância se amalgama com inédita intensidade, concentrada nos anos de nossa predileção nos quais, "à medida que vai perdendo o gosto ou ficando desencantado com a possibilidade de, como sociólogo, utilizar a engenharia social para transformar a realidade" ${ }^{128}$, a identificação à Sociologia vem a ser questionada pelo próprio Florestan. ${ }^{129}$ Com efeito, o aborto das vias democráticas era o malogro também do seu projeto de inserção da Sociologia na sociedade. A decorrente necessidade de reelaboração do constructo lhe consumirá os anos seguintes, os quais nos propomos a acompanhar.

Tudo se passa como se a perda da condição institucional se elevasse a um nível reflexivo, demarcando, em suas formulações, o rompimento, que política e institucionalmente, o regime militar havia promovido. Assim, a intensificação desse auto questionamento, que acompanha a crise ligada à aposentadoria compulsória e ao exílio, é marcada pela afirmação e reafirmação da ruptura com a instituição e a desilusão com relação à ciência - não sem alguma contradição, posto que o processo é detonado no interior da universidade canadense que o abriga, e valendo-se do instrumental analítico da própria Sociologia, guiado sempre por sua adesão inquebrantável à racionalidade moderna. A reflexão leva o pensamento a diversas searas, repondo a ruptura e a desilusão sempre em novas bases, como ficará evidente nos capítulos que seguem. Decerto, "Florestan estava imerso no que foi a maior crise de sua vida", pois foi atingido "em especial, seu entendimento da função revolucionária da ciência" no mundo moderno, "colocando-o frente ao desafio de uma profunda rearticulação do quadro fundamental de referência de sua posição teórica e política e de sua atuação profissional". ${ }^{130}$ As vicissitudes desse desafio nos ocupa agora.

\footnotetext{
124 "Florestan: memória e utopia". In.: Paulo H. Martinez (org.). Florestan ou o sentido das coisas, p. 12.

125 Boaventura de Souza Santos. "Florestan: um sociólogo comprometido com seu tempo". Estudos Avançados, n.26, v. 10. São Paulo, janeiro/abril, 1996, p. 19.

${ }^{126}$ Octavio Ianni, "Introdução", p. 9.

${ }^{127}$ Idem, p. 30.

${ }^{128}$ Boaventura de Souza Santos. "Florestan: um sociólogo comprometido com seu tempo", p. 19.

${ }^{129}$ Cláudio Vouga. "Evocações na contramão". Revista USP, n. 29. São Paulo, março/maio, 1996, p. 24.

${ }^{130}$ Sylvia Gemignani Garcia, Destino impar, p. 22.
} 


\section{The latin american in residence lectures: primeiras fissuras no scholar.}

A penosa mágoa que marca os escritos de Florestan Fernandes no atinente à traumática saída da universidade se faria sentir no período de exílio, quando o autor se propusesse $\mathrm{o}$ tema da condição intelectual. Nesse momento, sua atenção se dirige à problemática dos vínculos entre intelectuais e os regimes militares. Em função dela, estabelece cisões no interior da categoria intelectual e propõe à intelligentsia ${ }^{131}$ uma prática sociológica de resistência, que denomina como "sociologia da revolução". O processo de sua concepção é o objeto da apresentação seguinte.

$$
* *
$$

Ao tratar "A ditadura militar e os papéis políticos dos intelectuais na América Latina" 132 - em texto cujo título denota o enfrentamento sem tergiversação do problema que o mobiliza - Florestan Fernandes tinha por destinatário imediato o público acadêmico canadense. ${ }^{133}$ A compreensão esboçada acerca dos regimes militares é aspecto relevante para que o autor conceba os intelectuais que os apóiam; bem como para delimitação dos contornos de uma conduta científica oposicionista.

Tais regimes são compreendidos como um aborto do processo de inserção nacional na modernidade, de modo que os "valores de integração nacional - mesmo sob o capitalismo, e essenciais para uma revolução burguesa autônoma - foram esquecidos e abandonados." A necessidade de "democratização da renda, do prestígio social e do poder", bem como a integração de "milhões de pessoas excluídas ou semimarginalizadas em relação ao mercado, à ordem social vigente e à Nação foi completamente ignorada". Por isso, a "revolução" "nasceu como uma contra-revolução, um assalto ao poder organizado pelos e para os privilegiados, em sociedades nas quais os miseráveis constituem a maioria." 134

Assim, as primeiras formulações acerca do regime militar consistem num xeque-mate às expectativas de institucionalização do conflito social, já que "privatização do poder" indica que parte mínima do conjunto social se apropria do poder político. É sensível, no questionamento do tipo de modernização que se encampa politicamente, um esforço por precisar a diferença entre o que supunha por processo de modernização em curso e aquilo que

\footnotetext{
${ }^{131} \mathrm{O}$ autor usa o termo especificamente para se referir ao conjunto de intelectuais que se opôs aos regimes militares.

${ }^{132}$ In.: Circuito fechado. Quatro ensaios sobre o "poder institucional”. São Paulo: Hucitec, 1976.

133 Também os demais textos analisados nessa seção, com exceção da "Introdução" a Lênin, tinham por finalidade a discussão pública na Universidade de Toronto.

134 “A ditadura militar e os papéis políticos dos intelectuais na América Latina”, p. 110.
} 
historicamente se realiza, desafiando seus esquemas teóricos e interpretativos. Como setores da classe dominante, "alcançaram o monopólio de orientação política da sociedade, impondo seus próprios interesses" ${ }^{135}$ - a percepção de que a modernidade democrática foi eliminada pela ação contra-revolucionária de teor classista, conduz a reflexão a ter menos em vista os ideais modernos nacionais, e vincular-se às "forças de mudança", "grupos, classes e categorias sociais" e seus respectivos interesses em jogo na modernização. ${ }^{136}$ Em suma, o teor classista do regime militar e o aborto da modernidade colocam em dúvida a unidade social possível em torno da modernização como sentido histórico no qual se empenha o conjunto social nacional, revelam-na fissurada em torno dos interesses particularistas, que segmentam a instância estatal do poder político.

É evidente que os conflitos de classes já figuravam entre seus temas. Miriam Limoeiro Cardoso mostra que, nas análises do sistema de poder no capitalismo dependente, "classe" inclusive subordina "nação". ${ }^{137}$ Contudo, tal subordinação no plano analítico não faz dos conflitos de classes a base sobre a qual se fundamenta o projeto nacional moderno - cuja concretização superaria debilidades do capitalismo dependente, uma vez que o esquema vincula autonomização e democratização. ${ }^{138}$ No que concerne à questão aqui tratada, interessa ressaltar que os conflitos de classe não eram até então fator decisivo na delimitação da identidade e do papel social do cientista - apostava mesmo o autor na competência alicerçada na razão e na experiência da mobilidade social que os colocasse acima das divisões de classe, em prol do estabelecimento de uma ordem institucional na qual todas pudessem se colocar politicamente. Também o observa Miriam Limoeiro, para quem, se "Florestan leva muito a sério o condicionamento da produção de idéias pela inserção social de quem as formula", entende que os cientistas de "países dependentes tendem a ter mais sensibilidade para as questões envolvidas pela dependência." Ora, nessa espécie de identificação o condicionamento da visão do cientista se coloca num eixo nacional. Portanto, "ainda não qualifica sua diferença em função do regime de classes". ${ }^{139}$ Em suma, e decisivo para este trabalho, nesse aspecto, "classe" não subordina "nação".

\footnotetext{
${ }^{135}$ Idem.

136 "Sociólogos: os novos mandarins?". In.: A Sociologia no Brasil, p. 268.

137 Capitalismo dependente, autocracia burguesa e revolução social em Florestan Fernandes. Coleção Documentos n. 18, Série História Cultural 6, Instituto de Estudos Avançados, USP, julho de 1997, p. 2.

138 "Florestan: a criação de uma problemática". Estudos Avançados, n.26, v. 10. São Paulo, Janeiro/Abril, 1996, p.124.

${ }^{139}$ Idem, p. 120.
} 
Com efeito, dentro de uma orientação científica racionalista, a identidade intelectual só poderia ser apanhada pela perspectiva classista, vindo a colocar em dúvida a postura segundo a qual os intelectuais estariam acima de "particularismos", em face de um problema como o de estabelecer as "conexões estruturais e dinâmicas existentes entre o regime autoritário e os intelectuais". ${ }^{140}$ Questão que o leva a ver os intelectuais cindidos em uma "grande maioria" - que apoiou a militarização do poder político - e uma "minoria", que "se opôs à militarização do poder em nome de orientações de valor intelectuais". ${ }^{141}$ Assim, a maioria dos cientistas teriam violado os valores de liberdade e autonomia intelectual, preterindo-os aos vínculos de classe, sinal de sua traição de conjunto aos padrões modernos relativos à sua atividade. Tal compreensão torna insustentável a aposta numa concepção de intelectual acima dos interesses particulares e egoísticos dos grupos sociais. Daí afirmar que "os intelectuais não representam uma força cultural de toda a sociedade". ${ }^{142}$

Um ponto decisivo do constructo dizia respeito à localização dos cientistas sociais "acima" de "interesses particularistas" - sendo, aliás, a eles atribuída a iniciativa para solucionar o problema dos "critérios irracionais, ditados por interesses sociais egoísticos, por inclinações conservantistas" ${ }^{143}$ no trato político da sociedade. Contudo, essa asserção se orientava por uma irrisão patente, diante do novo encaminhamento: a suposição de que a "civilização baseada na ciência e na tecnologia", podia ser um processo do interesse social global, e garantida pela delegação de tarefas aos cientistas sociais, arautos dessa modernidade. A fratura evidente no projeto acadêmico político se liga à incompatibilidade do registro mannheimiano - especificamente no que tange à relativa superação das diferenças originárias de classe - em face das novas elaborações. Em Karl Mannheim, a constituição social diversificada da camada intelectual é o fundamento social para que a "complementaridade recíproca dos diferentes pontos de vista parciais - vinculados a posições distintas" possa servir de base para se "atingir uma visão de conjunto pela síntese dinâmica destas perspectivas unilaterais". ${ }^{144} \mathrm{O}$ membro da intelligentsia poderia "encarar os problemas de sua época a partir de mais de uma única perspectiva", pois, por ser "capaz de experimentar concomitantemente várias abordagens conflitantes da mesma coisa" ele é "menos engajado num lado do conflito". ${ }^{145}$ Entretanto, não é possível sustentar essa perspectiva, ao imbricar a

\footnotetext{
140 “A ditadura militar e os papéis políticos dos intelectuais na América Latina”, p. 123.

${ }^{141}$ Idem.

${ }^{142}$ Idem.

${ }^{143}$ A sociologia numa era de revolução social, p. 63

${ }^{144}$ Michael Lowy, As aventuras de Karl Marx contra o Barão de Münchhausen, p. 84-85.

${ }^{145}$ Karl Mannheim. Sociologia da Cultura. São Paulo: Edusp, Perspectiva, 1974, p. 81.
} 
diversidade social, a fragmentação interna e a desorientação política da intelligentsia, como o faz Florestan Fernandes diante de seus novos problemas: “devido à sua composição social, padrões culturais e identificações políticas, a emergente intelligentsia latino-americana constitui mais uma congérie, que um todo articulado e diferenciado". Isso porque, ela é "produto de interesses de classe e de ideologias divergentes: os intelectuais ilustrados, de origem 'burguesa' ou 'pequeno burguesa', a moral radical, de extração católica ou de outras raízes religiosas e humanitárias; o jovem rebelde, em sintonização com diferentes movimentos modernos de protestos de geração; os intelectuais definitivamente comprometidos com atividades e ideologias de esquerda, do anarco-sindicalismo e do socialismo às várias correntes atuais do comunismo; os tecnocratas politizados, fascinados pela revolução da ordem social.",146

Ainda assim, essa angulação sem precedentes, de teor classista, não é tomada como base para delimitação de novos papéis, indicando menos as orientações imediatas a que chega o autor que o tipo de problematização que passará enfrentar no trato da condição intelectual. É primordial que se avente, contudo, esse encaminhamento, pois sinaliza elementos na raiz de desenvolvimentos posteriores. De qualquer forma, a esta altura, o autor considera que os envolvimentos classistas produzam intelectuais que "desempenham seus papéis específicos de conformidade com 'as regras do jogo', estabelecida fora do mundo intelectual, por vezes até em termos extra-intelectuais" 147 - denotando, através da preocupação com a autonomia científica e a conduta intelectual, a ela correlata e com ela comprometida, a proximidade da reflexão àquele projeto acadêmico científico, que ainda o orienta fundamentalmente.

A cisão no conjunto da intelectualidade, tendo por linha divisória o apoio e a oposição aos regimes militares, não deve obnubilar o problema de fundo: já que as particularidades que segregam politicamente os cientistas são as mesmas que impedem a unidade do conjunto social nacional em torno da modernização, a posição relativa aos regimes militares interessa na medida em que expressa uma certa posição com relação à própria modernidade caminhando os deslocamentos do enfoque junto às nuanças quanto às alternativas vislumbradas para realizá-la.

Uma vez que a modernidade da qual era agente privilegiado se revela atravessada por interesses particulares, que subordinam os interesses "gerais", torna-se indefensável a idéia de que o "sociólogo aparece, assim, como uma espécie de elemento de vanguarda na consciência

\footnotetext{
146 “A ditadura militar e os papéis políticos dos intelectuais na América Latina”, p. 129.

${ }^{147}$ Idem, p. 133.
} 
dos problemas sociais". ${ }^{148}$ A fissura da expectativa na base do projeto acadêmico científico se faz sentir na afirmação de que o "comportamento crítico dos intelectuais", não é determinado "por qualquer virtude inerente aos intelectuais como um todo" ${ }^{149}$, capaz de definir sua orientação política, pois esta é, efetivamente, "uma função de suas polarizações de classe", sendo sua "reação política" a um regime autoritário "primordialmente uma questão de interesses de classe". ${ }^{150}$ Dessa maneira, o apoio que a ditadura militar encontra no interior das instituições universitárias indica o descaso com a própria autonomia, signo de seu descompromisso com a modernidade. Delineia-se, indubitavelmente, uma condição ambígua para seu projeto acadêmico político: pois se o apoio dos intelectuais aos regimes militares, através de sua subordinação à instância de poder externa o descredita, ele é ratificado, contudo, pela intelligentsia, que se opõe a ele através dos princípios da moderna produção científica.

Evidentemente, o escopo do trabalho não contempla o tentador exercício de se encontrar a profunda aderência dessas formulações à experiência recém vivida - e é certo que entre elas há inúmeras mediações. Contudo, parece mínimo o grau de elaboração da experiência, expresso num minucioso apego aos detalhes e na dificuldade da reflexão em abrir mão de infindáveis especificações e abstraí-las em nível teórico. A própria linha divisória entre aqueles que apoiaram e se opuseram aos regimes militares é aqui adotada como grande eixo que organiza o raciocínio do autor. Contudo, em sua argumentação, dentro desses dois grupos, há "tipos" que se multiplicam - em função de pequenas nuanças quanto à sua adoção ou refutação aos militares - conotando que, para cada um deles possa haver uma referência factual-pessoal na experiência recente, de tão rente que a formulação se encontra dela. $\mathrm{O}$ mesmo é saliente no trato das possibilidades de resistência do meio intelectual, em que cada uma, dada a minúcia e o detalhe parece remeter a um caso pessoalmente conhecido. ${ }^{151} \mathrm{De}$ maneira muito forte, vem à tona também, a combinação observada nas perseguições no interior da Universidade, entre posições políticas e concepções de trabalho intelectual sugerindo, inclusive que tenha sido associado a "esquerdismos", por sua orientação modernizadora. ${ }^{152}$ Infelizmente, a impossibilidade do intérprete de Florestan Fernandes trazer a seu texto a dinâmica do pensamento que plasma as imagens esboçadas, obriga-o a deixar aspectos dessa natureza apenas indicados.

\footnotetext{
${ }^{148}$ A Sociologia numa era de revolução social, p. 87.

149 “A ditadura militar e os papéis políticos dos intelectuais na América Latina”, p. 133.

${ }^{150}$ Idem.

${ }^{151}$ Idem, p. 132.

${ }^{152}$ Idem, p. 123.
} 
A proposta da camada intelectual como um grupo de síntese das perspectivas é, então, repensada. Contudo, a ambivalência com relação ao projeto originário se faz presente em fissuras e manutenções que sofre a partir de então. Se especificamente o aspecto flutuante do intelectual mannheimiano deve ser abandonado, especificamente o compromisso com a autonomia deve ser mantido e erguido como pilar de uma prática científica de resistência dado que, propor uma prática científica de oposição ao regime passa pela oposição ao tipo de prática daqueles que o apoiaram. O abandono expressa o declínio da concepção de um papel titânico do cientista e da ciência, do qual não se poderia aguardar outra posição, senão a de que a "Sociologia, como a ciência em geral, não é uma força sociocultural por si mesma", pois a "idéia de que a ciência e a tecnologia científica sejam, em si mesmas, um fator de

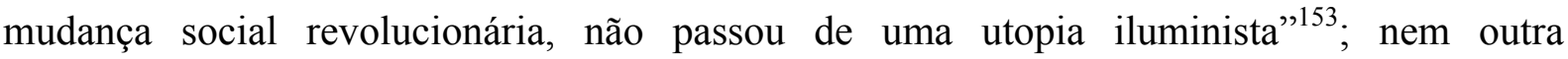
indagação, senão, com algum tom de ironia, no título de um de seus textos: "Sociólogos: os novos mandarins?" Por sua vez, a manutenção deixa patente a permanente adesão ao racionalismo da ciência, retomando inclusive, a orientação oferecida por seu constructo no episódio da Autodefesa, em que o pilar da autonomia coincidia com a oposição à ordem das coisas instaurada.

Entre as implicações daí oriundas, ganha destaque a elaboração de uma prática científica que, se terá por orientação precípua a manutenção da autonomia, não poderá descuidar do comprometimento com forças externas ao seu próprio campo. É evidente que na condição de catedrático, Florestan Fernandes também não associava isolamento e neutralidade à autonomia científica, tendo na origem mesma de seu projeto a contraposição a tal perspectiva. Tal dissociação, entretanto, não recomendava o vínculo entre intelligentsia e frações de classe ou posições políticas específicas - senão o compromisso com a instauração de um espaço político em que as diversas classes e interesses tivessem seu espaço de manifestação - exigência, que, em contextos sociais como o nosso, de bárbaro tratamento das questões políticas como questões policiais, já indicava o vínculo com a imensa maioria da população que não possui voz na política. Talvez por isso, considere o isolamento dos intelectuais na América Latina, uma espécie de "situação estrutural", na base de seus “comportamentos e orientações de valor" - à qual estão propositalmente sujeitos, com o fim de eliminá-los enquanto força histórica e mantê-los como defensores passivos da ordem social, na "torre de marfim", que os acomoda "às expectativas de papéis sociais e aos

\footnotetext{
153 "Sociologia, modernização autônoma e revolução social". In.: Capitalismo dependente e classes sociais na América Latina. Rio de Janeiro: Zahar, 2a ed., 1975, p. 150-151.
} 
controles societários externos." ${ }^{154}$ Ao negar essa forma típica de vínculo estabelecida entre os intelectuais e a ordem, as novas formulações para o compromisso intelectual não violam a autonomia científica, ao contrário, cumprem o papel de pressuposto para a defesa dela.

Forjar uma prática científica de resistência com base na autonomia da ciência, estabelecer vínculos com grupos de interesses sociais "particulares", opor-se ao isolamento social que articula cientistas à reprodução da ordem: trata-se de equacionar esses fatores numa proposta de prática sociológica de resistência. Florestan Fernandes não se furta a discriminar os elementos de uma "matriz intelectual de conhecimentos potencialmente revolucionários"155 - composta por objetos, problemáticas, perspectivas analíticas, um certa relação com os grupos sociais dissidentes, e pela adoção de uma orientação política - denominada "sociologia da revolução social". 156

No que se refere aos objetos, é preciso privilegiar "as atividades especificamente revolucionárias dos grupos humanos no centro das investigações sociológicas." ${ }^{157}$ A problemática definidora dessa Sociologia se apreende a partir de indagações retóricas como: "a quem beneficia a modernização?"; como "ela se organiza a partir das nações que incorporam as outras em seus espaços econômicos, socioculturais e políticos?" - nas quais o propósito evidenciar a dissociação entre desenvolvimento, autonomia nacional e democracia é patente -distinção, que, aliás, já era aspecto específico e diferenciador de sua crítica ao desenvolvimentismo, segundo Miriam Limoeiro. ${ }^{158}$ Para ele, tais "questões são fundamentais para o sociólogo" que quer "conhecer, para eliminá-los, os nexos negativos e os processos históricos-sociais que escravizam umas nações a outras." ${ }^{159}$ Quanto à perspectiva a ser adotada, indica a tomada da polarização entre "transformação e crise", como direções históricas abertas no presente. Por oposição à perspectiva sociológica que pretende compreender tão somente a formação, constituição e equilíbrio da ordem, o autor propõe uma outra, cujo núcleo definidor seja as opções históricas alternativas à ordem - os sociólogos ocupam-se do desenvolvimento "como um 'produto final' da evolução histórica", ignorando que ele garante somente "a continuidade da ordem existente"; contudo, quando "transformação e crise são elementos polares da criação teórica", a sociologia se torna "uma

\footnotetext{
154 “A ditadura militar e os papéis políticos dos intelectuais na América Latina”, p. 125.

155 "Sociologia, modernização autônoma e revolução social”, p. 126.

${ }^{156}$ Idem, p. 154.

${ }^{157}$ Idem.

158 "Florestan: a criação de uma problemática", p. 110.

${ }^{159}$ Idem, p.141-142.
} 
sociologia da revolução social, queiram ou não os detentores do poder e a repressão organizada da pesquisa sociológica”. 160

Há, é saliente, alguma afinidade com os propósitos finais de seu projeto acadêmico, pois permanece a expectativa de alçar autonomamente o Brasil no compasso da modernidade originária. Contudo, inviabilizado seu papel como arauto do processo que o regime se ocupa de protagonizar, resta-lhe questionar seus meios. Trata-se, então, de esgarçar os limites colocados pelas imbricações entre o tipo de conhecimento produzido pela ciência e a dinâmica da própria ordem social - o que leva à questão da limitação da imaginação sociológica no que tange a elaboração de alternativas à ordem. É certo que as "ciências da natureza não ficaram presas" às "concepções dominantes no meio social", contudo, da Sociologia foi feita "uma ciência 'natural' de processos sociais transcorridos e mortos", pois "mesmo quando a mudança se colocou como um aspecto central" a tendência foi "fazer da 'ordem existente' uma baliza mais ou menos circunscrita." 161

Nessas recomendações, encontra-se ainda a dimensão prospectiva - que torna impossível o esquivo do parentesco entre a "sociologia da revolução" a "Sociologia Aplicada”. Em ambas, é central a necessidade de rigor e precisão científicos para melhor orientação do agir, ao tributar a exatidão das análises à previsão das possibilidades no horizonte histórico - perspectiva explícita ao sentenciar: os que "pretendem uma alternativa socialista para o capitalismo, ou apenas suprimir o caráter dependente do capitalismo, precisam conhecê-la com precisão. ${ }^{162}$

Vale ressaltar que "socialismo" passa a ocupar, gradativamente, lugar análogo ao de “civilização moderna ocidental” no esquema anterior - a "única revolução, que poderia gerar o ambiente externo e o clima de valores requeridos pela ciência, é a que poderia resultar do socialismo igualitário e democrático." ${ }^{163}$ A ciência é compatibilizada com o socialismo porque vista como incompatível com o capitalismo. Talvez por isso, os elos sejam estabelecidos através de valores associados à ciência e em oposição ao capitalismo - os potenciais revolucionários do conhecimento "foram e são sufocadas no contexto capitalista, ou porque a ciência e a tecnologia científica são apêndices do processo de acumulação de capital, ou porque o uso social do talento é regulado de forma competitiva e exclusivista." 164

\footnotetext{
160 “Sociologia, modernização autônoma e revolução social”, p. 154.

${ }^{161}$ Idem, p. 155-156.

162 “A Sociologia Aplicada: seu campo, objeto e principais problemas”, p. 131.

163 "Sociologia, modernização autônoma e revolução social”, p. 124.

${ }^{164}$ Idem, p. 137-138.
} 
Daí uma tendente crítica à civilização moderna ocidental, que passa a ser tratada do ângulo não mais de sua racionalidade, mas em sua dimensão "não racional", típica de sua realização no modelo capitalista - "já não se pode alimentar as ilusões iluministas", pois a "utopia da 'revolução através da e pela ciência' perdeu consistência", ainda que aí estivesse a "matriz de um conhecimento racional", ela "não teve potencialidades para destruir o contexto irracional dentro do qual se fomentou sua expansão" resultando numa "libertação parcial do homem". ${ }^{165}$ Descrédito que não impede assegurar que aqueles que não conhecerem as alternativas mencionadas com a devida precisão, "em vez de trabalharem por um objetivo ou por outro, irão ajudar a fortalecer a recomposição" do capitalismo dependente. ${ }^{166}$

Indubitavelmente, a demarcação estabelece uma intervenção na realidade, "como sociólogo"167 - sobre a qual é possível pensar que esteja ligada a seu antigo projeto de construção dos contornos de uma especialidade da sociologia, a Sociologia Aplicada. Com efeito, a crise instaurada pela aposentadoria compulsória não eliminaria a bagagem da formação do autor, ganhando saliência a vertente mais pragmática de seu constructo, quando se debruçasse sobre os papéis dos cientistas sociais. Reflexão ímpar, na qual tal bagagem se coloca com força inesperada, faz desse o momento oportuno para que se referencie a "Introdução" a Lênin, fruto de famosa leitura, empreendida durante seu exílio.

Ao que tudo indica, entre 1969 e 1972, esteve dedicado aos estudos relacionados às revoluções chinesa, cubana e russa. ${ }^{168}$ Dentre esses estudos, a aproximação com o universo cultural da esquerda de orientação marxista e revolucionária seria coroada com a conclusão da introdução para o "Livro de Leituras sobre o Lenine". ${ }^{169} \mathrm{Na}$ apresentação, sobressaem marcas indeléveis de sua formação sociológica, sendo mesmo possível encontrar no tipo de conhecimento produzido por Lênin, um representante exemplar de seu próprio ideal de produção científica, mesclando o paradigma da "Sociologia Aplicada" às finalidades da "sociologia da revolução". É evidente que a aproximação entre a tradição da sociologia clássica e o marxismo clássico deva-se também a uma identidade de base entre ambas "que emergiram alinhadas à concepção racionalista da ciência característica da modernidade

\footnotetext{
${ }^{165}$ Idem, p. 124.

${ }^{166}$ Idem, p. 131.

${ }^{167}$ Gabriel Cohn, "Padrões e dilemas; o pensamento de Florestan Fernandes", p. 126.

168 "Em busca de uma sociologia crítica e militante". In.: A Sociologia no Brasil, p. 204.

169 Bárbara Freitag, "Florestan Fernandes por ele mesmo", p. 158; "Introdução". In.: Lênin: Politica. São Paulo: Ática, 1978.
} 
clássica, afirmando convictamente o poder do saber científico para o controle racional do mundo" ${ }^{170}$ - aspecto facilitador, inclusive, da apropriação que apresentamos.

Aplicação, instrumentalidade, previsibilidade são traços definidores da produção leniniana e determinantes de sua eficácia política revolucionária, para Florestan Fernandes. A figura de Lênin delineada, em nada deixa a desejar os propósitos da Sociologia Aplicada e aos objetivos da "sociologia da revolução": através de uma exata análise apreende racionalmente os sentidos possíveis de sua própria intervenção - pedagógica, política, publicista, e por aí alça o patamar almejado por aquela vertente: o trato, no corpo teórico, dos desdobramentos da própria intervenção. Eis a afinidade básica entre o alvo de "introduzir na explicação sociológica critérios de análise prospectiva"171 e aquilo que se tributa a Lênin.

Aproximação nada incolumemente, aliás. Pois seu argumento tem a força de se esmerar numa trajetória em que o compromisso interventor da produção teórica é indiscutível, tal qual o desfecho bem sucedido do processo histórico no qual intervém. O historiador não pode deixar de observar que joga papel decisivo nas concepções em tela a circunstância de conhecimento do desfecho dos eventos. Estando - condição inexorável - o desfecho histórico bem sucedido da revolução sob o crivo de uma análise elaborada na posteridade, esta, se ganha por conhecê-lo, perde por transformar a contingência em destinação. O ganho permite a elaboração de um sentido para os acontecimentos, imprimindo racionalidade ao passado; mas, perde, com isso, ao eliminar as inúmeras outras possibilidades de desfecho e a dimensão de acaso que tão lapidarmente caracteriza o curso das coisas. Quando o propósito é a reconstituição do passado, bem sabemos, não são poucos os problemas e como contorná-los está na origem das controvérsias mais interessantes na discussão historiográfica. Contudo, estabelece-se um qüiproquó na teorização da teoria, quando se pretende atribuir a racionalidade elaborada a posteriori a um dos agentes coevos aos acontecimentos e erigi-lo em exemplar de previsibilidade sociológica. E, ao que parece exatamente esse é o propósito de Florestan Fernandes. Daí oscilações inevitáveis, intransponíveis ao texto do intérprete, senão ao custo de deselegantes transcrições, que tributam o sucesso da revolução socialista por vezes à mobilização da massa, por vezes à vanguarda profissional, mas, sobretudo ao suposto "modelo de ciência" de Lênin. Daí também que, ao estabelecer uma relação causal entre precisão da análise e o sucesso da revolução, o autor pareça projetar sua ambição irrealizada na vertente da Sociologia Aplicada. Com efeito, tendo em vista que se trata de uma

\footnotetext{
${ }^{170}$ Sylvia Gemignani Garcia, Destino impar, p. 123.

171 “A Sociologia Aplicada: seu campo, objeto e principais problemas”, p. 125.
} 
trajetória bem sucedida no que tange à intervenção, tudo se passa como ela desse vida àquela que era a pretensão do próprio autor.

Entre a "sociologia da revolução", a Sociologia Aplicada, e a produção teórica de Lênin podem ser encontradas problemáticas paralelas e questões que a tradição marxista coloca à sociologia. É interessante observar que, se, no que tange ao "controle da mudança social", a Sociologia Aplicada pressupunha um processo de mudança social em curso, mínimo necessário; também Lênin será valorizado pela teorização de uma espécie de racionalização máxima do mínimo existente, o que em jargão marxista se traduz pela dimensão do "marxismo leninismo", que não se intimida com as adversidades das "condições objetivas", mas explora as "condições subjetivas", das quais procura extrair o máximo do rendimento político - assinalando a capacidade de Lênin em extrair do "atraso" russo exatamente as condições vantajosas para insuflar movimentos revolucionários. Dentre outros aspectos, esse sugere uma equivalência entre a obra - política e teórica - de Lênin e a consideração das relações da "sociologia da revolução" com os grupos sociais a que se deve vincular, na medida em que o autor postula como sua finalidade: "iluminar criticamente a percepção do homem comum e suas reações societárias de autodefesa coletiva". ${ }^{172}$ A atualização da vocação iluminista, traduzida na noção de vanguarda leninista, se embate e se amalgama com o declínio do papel vultuoso do cientista social, antiga vanguarda de Florestan Fernandes. Afinal, na "sociologia da revolução", “o sociólogo politicamente responsável” deve acompanhar "em suas teorias as orientações de comportamento dos grupos e classes sociais que atuam revolucionariamente", operando a relação com a sociedade como um freio à elucubração - para "evitar a fabulação e um revolucionarismo intelectualista" é necessário manter as formulações rentes "ao nível da percepção, das atividades práticas e das aspirações" dos grupos com os quais se vincula a prática sociológica. ${ }^{173}$ Declínio que tem contrapartida em Lênin, pois em seu entendimento, o decisivo para o russo era: "naturalmente, o proletariado, como sujeito da ação revolucionária em escala coletiva" ${ }^{174}$ Entretanto, há um impasse, pois a prioridade lógica da classe revolucionária para a revolução não eliminava a presença política de "revolucionários profissionais", cuja tarefa era "contribuir para a expansão da consciência de classe do proletariado de fora para dentro" $" 175$ - tensão que no

\footnotetext{
172 “Sociologia, modernização autônoma e revolução social”, p. 142-143.

${ }^{173}$ Idem, p.154-155.

174 “Introdução", p. 19.

175 Idem.
} 
jargão marxista se coloca como relação entre vanguarda e massas, e para o sociólogo, foi equacionada com felicidade por Lênin, de que dá ratificação histórica, a própria revolução.

É evidente que reconhecemos o quão problemática é tal concepção. Entretanto, sem o propósito de esgotar a polêmica que ela origina, é preciso aventar o sentido desse posicionamento na reflexão de Florestan Fernandes. O impasse de fundo - afinal, o acento da decisão histórica está na vanguarda ou na massa, no controle racional ou no curso histórico parece em suspenso. E a desilusão com relação à "utopia iluminista" tem o valor de constatação, não é substrato a partir do qual se erga outra proposta de prática intelectual. Mas isso não impede certa inversão na dinâmica de seu pensamento. As lamentações, antes tão determinantes para a delimitação das tarefas intelectuais - "o horizonte cultural é sufocante não contendo um mínimo de noções que permitam estabelecer um intercâmbio ativo entre o leigo e o cientista" e o "grau de secularização das concepções dominantes se revela incapaz sequer para harmonizar os dois universos" $" 176$ - distam e divergem do apelo para que "novos grupos estimulem ou forcem os intelectuais a fazer uma revolução em sua ótica intelectualista" e possam forjar "novos usos alternativos da ciência e da tecnologia científica". ${ }^{177}$ Nesse aspecto, como em outros, Lênin desempenha um papel modelar, representando a solução historicamente bem sucedida para problemas que o sociólogo esboça, por exemplo, aquela "situação estrutural" de isolamento da intelligentsia latino americana. ${ }^{178}$ Não por acaso, Florestan Fernandes destaca a "disciplinarização dos revolucionários" e a eliminação de traços burgueses de seu estilo de vida, impeditivos de um cumprimento de dever satisfatório - elogio a Lênin, que, cotejado com seu incômodo crescente quanto aos vínculos de toda espécie dos intelectuais com os benefícios da ordem, sugere novamente a projeção de sua própria insatisfação. Estas, inúmeras passagens e mais o tipo de apropriação de Lênin assinalada atestam que o valor da conduta sobrepõe-se, em 1972 à própria incorporação teórica de Lênin, que se dará efetivamente apenas com a retomada e conclusão da obra sobre a revolução burguesa no Brasil. Não seria exagero dizer que, enunciar sua identidade política socialista - "Eu sou, ao mesmo tempo, sociólogo e socialista" ${ }^{179}$ consista numa auto-afirmação política, pois esse assumir não se transforma em base a partir do qual se erige suas propostas, havendo, através do plano ético, uma associação entre a posição política e a conduta científica.

\footnotetext{
${ }^{176}$ A sociologia numa era de revolução social, p.60-61.

177 "Sociologia, modernização autônoma e revolução social”, p. 141.

178 "Introdução", p. 12.

179 “Sociólogos: os novos mandarins?”, p. 268.
} 
Há que se destacar, nesse sentido, como a identificação socialista, na base da "sociologia" de Lênin, é articulada com o conjunto de sua reflexão, a respeito de opções político-partidárias. Em seu compromisso, deve a intelligentsia estar a serviço dos grupos que atuam na direção da constituição daquele padrão moderno, aqui identificados com o largo espectro de posicionamentos, que vai da revolução "dentro da" à revolução "contra a ordem", sendo o sociólogo útil "aos diferentes grupos e classes sociais emprenhados" 180 tanto em uma como em outra. Isso porque, se não há "uma revolução social", "para todos os países da América Latina", há, porém, apenas "um meio de projetar a Sociologia como ciência nas eclosões revolucionárias nesses países": "alimentar os processos de revolução social com conhecimentos sociológicos objetivos e críticos" que garantam a "eficácia política dos grupos e classes sociais empenhados na transformação revolucionária das sociedades latinoamericanas." 181 Assim, é possível notar também que, a despeito do que a elogiosa apresentação de Lênin e a eloqüente enunciação de sua identidade política socialista podem sugerir, o comprometimento intelectual subordina a posição política pessoal, pois não é ela que justifica a prática científica de resistência. Em uma fórmula simples e congruente com sua preocupação, poderia se afirmar que a adoção da perspectiva pessoal na militância transformaria o dever do esclarecimento em impalatável persuasão. Por isso, se, "pessoalmente", o autor é “cético a respeito da revolução dentro da ordem”, obriga-se a não omitir sua existência e suas potencialidades. ${ }^{182} \mathrm{O}$ socialismo é entendido como única civilização compatível com a ciência, entretanto é incompatível com a prática científica que sua defesa exclusiva impeça o esclarecimento daqueles que a ele não aderem.

Permeia as recomendações - e esse é o perigo subreptício de uma proposta de conhecimento compromissado politicamente, mas que não se permita a vulgaridade - o risco da partidarização e o panfletarismo. $\mathrm{O}$ autor não foge dele. Tanto o vínculo com a ordem quanto o vínculo com a política de negação da ordem, em seu entendimento, podem conduzir a ciência ao empobrecimento - perspectiva afinada com o que assinalamos: a oposição à conduta dos intelectuais que sustentaram os golpes militares, passa necessariamente pelo compromisso com a oposição política e com a insubordinação da autonomia do campo ao compromisso político. Daí afirmar que o cientista deva "vencer-se a si mesmo, para resguardar sua integridade intelectual, tanto contra as forças incontroláveis de opressão quanto contra as tentações do dogmatismo partidário". Pois se "a militância política do

\footnotetext{
180 "Sociologia, modernização autônoma e revolução social”, p. 153.

${ }^{181}$ Idem, p. 157.

${ }^{182}$ Idem, p. 153-154
} 
sociólogo como e enquanto cientista" não exclui sua militância política "como ativista de um movimento político-social ou de um partido" - essa compatibilidade entre "cientista" e "ativista" está condicionada à não submissão de uma atuação a outra, de modo que, nem a política submeta a ciência e nem a ciência subjugue a política. Dessa maneira, para que sejam duas atuações, que se alimentem reciprocamente, é necessário que sejam mantidas sua autonomia e distinção, pois a submissão de uma a outra tem por conseqüência a eliminação de uma delas: o sociólogo, para "manter a Sociologia como uma influência ativa" deve ultrapassar “pressões que tentam destruí-lo em nome da 'defesa da ordem', ao mesmo tempo que precisa encontrar uma harmonização construtiva entre os dois tipos de militância com que se depara". ${ }^{183}$ Com efeito, tendo em vista a oposição às concessões político-classistas na gênese dessas proposições, não seria a esta altura que se abriria mão da autonomia, passando de sua impossibilidade numa instituição (Universidade), para sua desobrigação em outra (Partido). Impossível, contudo, não se surpreender com esse amálgama entre o elogio de Lênin enquanto intelectual e a refuta veemente do intelectual em geral como partidário. Apenas a ambigüidade da experiência social, na base das formulações, impede que se veja nisso uma aberração.

Por isso é importante também sinalizar as diferenças entre as elaborações. Não se pode escamotear que a "sociologia da revolução" seja enfaticamente apresentada com um caráter instrumental, que a aproxima da Sociologia Aplicada. Contudo, esta era uma, entre diversas vertentes, nas quais a Sociologia era dividida, dentro dos propósitos últimos de institucionalização do conhecimento sociológico. ${ }^{184}$ Já sua "equivalente”, carece do respaldo de conjunto disciplinar, mantendo o caráter instrumental. $\mathrm{O}$ intérprete não deve se eximir de assinalar a tensão. É imperativo indagar, como o autor enfrenta o possível o conflito entre os dois compromissos firmados na gênese da "sociologia da revolução" - com os "grupos sociais empenhados na transformação social" e com a autonomia da ciência - que implica em, ao mesmo tempo, ter de produzir uma ciência autônoma e instrumental a grupos específicos.

Mutatis mutandis, é a esta indagação que, autodefensivamente, o autor procura responder, ao supor a acusação de a "sociologia da revolução" trazer "uma carga política e ideológica" - ao que opõe: "O mesmo não sucede com a outra, com sua falsa neutralidade?"185 Para ele, tal acusação à "sociologia da revolução", consistiria também numa

\footnotetext{
${ }^{183}$ Idem, p. 157.

184 A divisão consistia em: Sociologia Sistemática, Descritiva, Comparada, Diferencial, Aplicada, Geral ou Teórica, e Sociologias Especiais. Maria Arminda do Nascimento Arruda, Metrópole e cultura, p. 244.

185 “Sociologia, modernização autônoma e revolução social”, p. 143.
} 
"adesão de caráter político e ideológico", porém "às alternativas que favorecem as nações modernizadoras"; pois, a "ciência é instrumental nos dois níveis". ${ }^{186}$

É válido destacar, como expressivo desse compromisso - com a autonomia e a intrumentalização - o encaminhamento dado ao problema da relação entre "teoria e realidade" na história in flux. Para ele, "as teorias sempre transcendem a realidade"187. Dessa maneira, se concebe que seria intrínseco e constitutivo da ciência, ultrapassar as limitações do movimento social, sem sofrer de sua debilidade; como explicar, que também considere: "Pode ser que, no final das contas, a contribuição do sociólogo fique aquém de suas intenções", e então, a teoria, a reboque da história vivida, ganhe "muito com o envolvimento político do sociólogo."? ${ }^{188}$ O argumento inverte a relação entre teoria e realidade, com o fim de defender a mesma conduta científica compromissada. Não é o caso de se contrapor o autor às próprias palavras, mas apreender o fundamental nessa oscilação - tanto ao afirmar o avanço quanto ao reconhecer o atraso da teoria com relação aos processos históricos, as considerações se prestam à defesa do vínculo entre a ciência e os movimentos sociais. Isso é indicativo de que mesmo o rigor da construção lógica sucumbe nesse momento à premissa do compromisso com os movimentos sociais dissidentes.

Como não atinar novamente para a dinâmica entre as duas éticas? Pois, não é o esforço pelo equilíbrio entre o aspecto instrumental e o compromisso com a autonomia uma remetência dramática aos conflitos, aproximações e distanciamentos entre a ética da responsabilidade e a ética da convicção? Se a astúcia diante da prisão proporcionou a intersecção entre ambas; aqui o dilaceramento oriundo delas é preponderante. A convicção na razão e na ciência faz com que o argumento jamais abandone o pilar da autonomia, ao passo que a responsabilidade e o compromisso social, mirando as conseqüências e o sentido da produção científica isolada socialmente, conduzem à defesa rigorosa de uma prática científica que tenha por fim sua instrumentalização. A ética da convicção sustenta o valor da autonomia da ciência e a ética da responsabilidade imprime sentido à instrumentalização - remetendo ao problema dos meios e dos fins no campo da ética, porque é o fim "bom" que orienta a responsabilidade, mas ela é colocada em xeque pelos "meios", aqui figurados na instrumentalização necessária para realização desse fim.

\footnotetext{
${ }^{186}$ Idem.

187 “Sociologia, modernização autônoma e revolução social”, p. 155.

${ }^{188}$ Idem.
} 
Delicada problemática de fundo teórico também não pode ser ignorada. É sensível que o deslocamento, ainda que com todas as nuanças assinaladas e as cores mais simbólicas que teóricas de que ainda se reveste, da "civilização moderna" para o "socialismo", no esquema apresentado, implicaria também no deslocamento dos sujeitos privilegiados de sua realização histórica. Assim, o que permanece suspenso e na origem desses impasses diz respeito à superioridade do esclarecimento baseado na ciência, que tem afinidade com a "vanguarda leninista"; contraposto à crescente redução do protagonismo da Sociologia, do cientista social e a dúvida quanto à suficiência e quanto ao potencial da esfera científica para intervenção, que parecem caminhar rente ao adensamento da subjetividade histórica do objeto desta Sociologia, a classe revolucionária. Desenha-se um terreno de relações complexas, pois são contemporâneos o cientista e o sujeito/objeto da investigação - ambos em busca do sentido histórico e do papel que desempenham na transformação revolucionária. Não sendo a "massa" apenas objeto de estudo e "consumidora de conhecimentos", ela "se define como único agente que pode decidir em termos finais, se haverá a vitória de uma revolução" ${ }^{189}$; mas essa vitória encontra-se entre as pretensões de apreensão do edifício teórico - problema que será esgarçado pela reflexão ao longo dos anos que nos ocupa.

Evidentemente, a indagação acerca da imbricação entre autonomia e instrumentalização, não supõe a neutralidade como oposição à proposta de Florestan Fernandes. Quer, porém, colocar em relevo a objetividade ambivalente em jogo, pois há um tipo de avaliação divergente dos princípios da ciência ao lançar a um parâmetro socialmente externo a validade de seus resultados, no interior de um esforço que, contudo, procura assegurar a autonomia, em seus parâmetros próprios de validação. Entretanto, não é a essa questão que o autor responde. Ao devolver a pergunta a uma suposta acusação - "O mesmo não sucede com a outra, com sua falsa neutralidade?"190 - tudo se passa como se a constatação de que o conhecimento tenha inexoravelmente uma significação política propicie o entendimento da instrumentalidade como igualmente inescapável. Tal suposição conduz a uma equivalência entre o comprometimento passivo, através da neutralidade e do isolamento, e o comprometimento assumido, que ele defende. Equivalência esta superada através do estabelecimento de um critério que diferencie ambos - a ética: "Há uma ética inerente à responsabilidade científica e ela impõe um mínimo político que compele o sociólogo à confrontação." ${ }^{191}$ Entretanto, a preocupação em tomar a ética como elemento intrínseco à

\footnotetext{
189 "Introdução", p. 35.

190 “Sociologia, modernização autônoma e revolução social”, p. 143.

${ }^{191}$ Idem, p. 153.
} 
ciência, não oculta o fato de que ela está no campo do que se faz com a ciência e não dela mesma, de modo que atribuir à ciência uma "ética intrínseca" nada mais é que propor uma certa ética e uma certa ciência - não sendo portanto, a ética, fundamento científico do papel delimitado para o cientista.

Não seria apropriado ignorar evidente afinidade entre pontos aqui destacados e as clássicas formulações de Max Weber sobre a objetividade científica e a responsabilidade do cientista, tais como a impossibilidade de se determinar cientificamente a finalidade da ciência - aspecto que em Florestan Fernandes parece decisivo para o abandono da perspectiva segundo a qual a própria ciência oferecia os caminhos a serem trilhados por ela, para a elaboração de uma "ética científica". Além disso, a responsabilidade ética da ciência conferida por sua capacidade de indicar com maior clareza o sentido das ações humanas, que implica em apontar, com base no pensamento racional, as diversas hipóteses de saída e possibilidades disponíveis aos homens. A reflexão, longe da delimitação weberiana dos papéis intelectuais, parece próxima de dilemas que a ela deram origem. Equacionar o papel intelectual em tempos de profunda transformação e com poucas margens de ação histórica talvez faça ambos convergirem no reconhecimento dos limites colocados às produções do espírito, o que não exime a ciência de responsabilidade, mas a impede de propor a finalidade de seu próprio uso, e, por conseguinte de contornar cientificamente as tarefas sociais do cientista. ${ }^{192}$ A arbitrariedade em última instância, da perspectiva e do uso social da ciência, se ratifica a concepção de que ela sirva ao esclarecimento, duvida de sua capacidade para orientar seu próprio uso, cedendo esse papel para a ética.

Se concordarmos com Jean-François Sirinelli, o problema dos vínculos com a sociedade não é ético, mas histórico - ainda que freqüentemente seja "colocado, inclusive pelo próprio intelectual em termos éticos" ${ }^{193}$ - podemos entender que a eleição da ética como fundamento de legitimação e o esforço por afirmá-la como intrínseca à ciência são verdadeiramente índices de impasses de fundo nas formulações. Impasses estes que retomam a dúbia condição em que se encontra o projeto acadêmico político, assinalada no início dessa seção.

Novamente, seus comentários sobre Lênin são inestimáveis. Neles, esses impasses se manifestam caracteristicamente. Não fosse já motivo de reflexão que a apresentação de uma trajetória revolucionária propiciasse tão fortemente a emergência do traço universitário, o

\footnotetext{
${ }^{192}$ Ver: Fritz K. Ringer, O declínio dos mandarins alemães, p. 324 e segs.

193 Jean-François Sirinelli. “Os intelectuais”. In. René Rémond (org). Por uma história política, p. 261.
} 
fenômeno seria especialmente interessante ao notarmos os critérios de valorização do perfil intelectual e político que orientam a apresentação. A despeito do notório esforço em forjar uma marginalidade com relação ao universo acadêmico científico, Florestan Fernandes leva a tradição marxista clássica revolucionária para o centro de uma "fascinação" tipicamente acadêmica, aliás, confessa: "havia me acostumado tanto à imagem dominantemente política, que encontro grande sedução em alargar as vias de compreensão do homem e do seu talento", na verdade, em Lênin o "mundo perdeu um scholar completo e apaixonado". 194 A "Introdução" de Florestan Fernandes faz jus ao título da coleção. Como um "Grande Cientista Social", a todo momento, Lênin tem seus méritos repostos segundo aspectos em tudo afinados com o perfil de trabalho do próprio Florestan Fernandes, quando chefe de Cadeira na Universidade: rigor, precisão, amplitude de conhecimento teórico, procedimentos empíricos. 195 Assim, há um dilema entre a valorização da produção de Lênin segundo uma demanda e uma eficácia política, e a valorização de uma legitimidade haurida no campo da ciência, tornando-se patente a incongruência entre os dois parâmetros. Pois a ciência, autoreferenciada e com seu próprio paradigma de validade assertiva, não pode conferir à política ainda que em amplo sentido, desde os movimentos que a "absorvem" até o sucesso da revolução por ela orientada - o poder de validá-la. Questão insolúvel a esta altura e deixada sem encaminhamento pelo próprio autor, saliente-se que a aproximação com o campo cultural da esquerda marxista, através do deslocamento da tradição sociológica para a tradição do marxismo clássico, não implica em virada nos critérios de avaliação da produção intelectual, ainda bebidos em parâmetros afinados com os princípios de Florestan Fernandes universitário. 196

É claro que há nuança salutar nessa passagem da Sociologia Aplicada à "sociologia da revolução". Não estabelecem a mesma relação com a ordem social vigente. A Sociologia Aplicada permitia que Florestan Fernandes detectasse os problemas de uma ordem social, elaborando um programa de intervenção que os resolvesse segundo a dinâmica dessa mesma ordem. ${ }^{197}$ Já a "sociologia da revolução", está comprometida com diversas "gradações" revolucionárias, contemplando, inclusive, a "revolução contra a ordem”. Esse deslize tem seus

\footnotetext{
${ }^{194}$ Apud. Eliane V. Soares, Florestan Fernandes: o militante solitário, p. 78 - carta não publicada por Bárbara Freitag em "Florestan Fernandes por ele mesmo".

195 Vale conferir os critérios que justificam a seleção dos textos da coletânea ("Introdução", p. 46-48); e a definição de "ortodoxia" leninista (Idem, p. 15).

${ }^{196}$ É indefensável, portanto, em posse de uma análise mais minuciosa de sua produção, a idéia de que a crise com relação à instituição universitária se traduza numa valorização imediata da esfera política, como fica sugerido na interpretação de Eliane Veras Soares, Florestan Fernandes: o militante solitário, p. 78-83.

${ }^{197}$ Gabriel Cohn, "Padrões e dilemas; o pensamento de Florestan Fernandes”, p. 134-136.
} 
desdobramentos. Vimos acima, como a necessária coerência com relação às conclusões a que o autor chega, sobre as imbricações entre intelectuais e regimes militares, resulta numa ambivalência do próprio projeto acadêmico. Encontram-se aqui as conseqüências últimas dessa condição, na medida em que, do ângulo de sua ratificação, temos a permanente defesa da autonomia; ao passo que, do ângulo de seu questionamento, a demanda por vínculos com os grupos sociais, acaba por deslocar a instituição enquanto fonte de prestígio e parâmetro de validação científica.

Esse deslocamento é sensível no esforço do autor não apenas em dissociar o mérito científico da inserção institucional, mas em tomar a dissidência institucional fonte de mérito científico - dois movimentos prodigamente encontrados na apresentação de Lênin, em que o desajuste com relação às instituições é signo privilegiado da conduta revolucionária. Tudo se passa como se a instituição operasse como referencial negativo, cuja contraposição realça o mérito. $\mathrm{O}$ autor delineia um contraste entre o valor de suas competências pessoais e seu não reconhecimento, devido sua atividade revolucionária. Assim, pululam no texto termos ligados à valorização do desempenho intelectual - como "êxito", "brilhantismo" - no mesmo passo em que se assinala seu não enquadramento institucional, uma vez que a "atividade política revolucionária" é "causa para o não exercício da atividade profissional". ${ }^{198} \mathrm{Na}$ dissociação entre genialidade do talento e próspera carreira que poderia alçar, a gênese da produção que o "fascina" - "Lenin nunca procurou afirmar-se como cientista social (e tampouco, em sentido mais amplo, como scholar)", contudo, "não só possuía excelente formação universitária, vocação de investigador e erudição histórica", como também "aprendeu com maestria a complexa tradição científico filosófica inerente ao movimento socialista europeu e russo, nos vários domínios do conhecimento e em particular no estudo histórico-sociológico do homem em sociedade". 199

E ainda, a enfática atenção dedicada a alguns aspectos da trajetória de Lênin remete a delicadas questões para o próprio autor, como a problemática inserção na vida escolar e universitária, ganhando destaque os vínculos entre as "expulsões" e as "atividades políticas revolucionárias" de Lênin. Avulta, no trato desse aspecto, a experiência histórica de seu passado recente. $\mathrm{Na}$ auto-imagem ali elaborada, a origem social humilde, a sofrida socialização escolar da infância e juventude, e a ruptura traumática com uma inserção

\footnotetext{
198 “Introdução", p. 9.

${ }^{199}$ Idem, p. 22.
} 
institucional até então bem sucedida transformam-se em signo de sua própria identidade política dissidente.

Paulo Silveira foi quem primeiro observou que essa "Introdução" possui aspectos em que comentarista e comentado se assemelham. Contudo, a sugestão que elabora, adotada adiante, inclusive, liga-se ao momento da publicação do texto. $\mathrm{O}$ "publicista revolucionário"200, inspirado em Lênin tem expressão pública salutar em 1978. Porém, elabora seu texto marcado indelevelmente por sua formação sociológica e pelo afastamento da Universidade. A consideração da trajetória de Lênin, menos que sinalizar uma imediata incorporação de natureza teórica, menos que promover uma imediata adesão à atividade de publicista, parece lhe oferecer a possibilidade de romper com a centralidade da instituição enquanto fonte de valor, sem que rompa com as bases do projeto que ela abrigava, dissociando a inserção prestigiosa institucional do mérito científico. O que encontra em Lênin lhe convoca o esforço por compatibilizar duas dinâmicas distintas de avaliação - a estritamente científica e a política - ao atribuir relativamente a uma, a eficácia da outra. Ainda que, quando tente formular essa unidade, enquanto "sociologia da revolução", não encontre nem o paradigma científico que antes alicerçava o projeto de intervenção, e deva defendê-la tomando por fundamento a ética, nem o substrato revolucionário que deu corpo histórico às análises "precisas" de Lênin.

Portanto, a despeito da "crise" assinalada - no repensar a relação com a ciência, no crescente desencanto com a atividade científica - na Sociologia ainda são hauridos o paradigma da resistência e o instrumental que permite a própria reflexão sobre a crise intelectual. A manutenção do arcabouço da vertente aplicada do projeto original, adentrada por novas finalidades, compõe um quadro de tensões que se equacionam deixando problemas em suspenso - mormente o conflito entre os dois compromissos firmados, a intrumentalização e a autonomia científicas - e sinalizando rupturas moleculares acaba por postergar a reordenação de conjunto. Deve-se reconhecer, com Heloísa Fernandes, que nesse momento, "a Sociologia seja o verdadeiro centro de referência do seu discurso". 201 A reordenação se processa nos anos a que este trabalho se dedica, sendo mantido, não sem um oscilante descrédito crítico - o critério da ética para contornar a mencionada tensão, enquanto a reflexão e a história se mostrarem incapazes de oferecer outra referência. A redefinição dos termos em novo constructo se consolida num contexto histórico marcadamente distinto, no

\footnotetext{
${ }^{200}$ Paulo Silveira, "Um publicista revolucionário”. In.: Maria A. D’Incao (org.). O saber militante, p. 287.

201 "Chaves do exílio e portas da esperança", p. 13.
} 
que diz respeito à atuação dos intelectuais na vida pública, e com uma volumosa autocrítica acumulada pelos exercícios de depoimentos autobiográficos do autor - nos quais a cisão entre ciência e instituição científica é esgarçada ao máximo, drama de que nos ocupamos no capítulo seguinte. 
Capítulo II

Perda: Entre o não ainda e o já não mais (1973-1978) 
O passado não é meu amigo, Eu desconfio do meu passado.

Mario de Andrade.

\section{Sentado assim Entre o ainda não e o já não mais Não acredito no que penso!} Só pode ser um engano, que se esclarecerá Amanhã! Então por que falar hoje? De que Serve construir o barco se o rio está seco?

Bertolt Brecht

Não está ao meu alcance criar uma sociedade ideal. Contudo, está no meu alcance descrever o que, na sociedade existente não é ideal para nenhuma espécie de existência humana em sociedade... trata-se de equacionar, sociologicamente a negação de um presente indesejável. 
A concepção segundo a qual o passado seja uma construção do presente é corriqueira entre aqueles cujo métier tem centralidade na relação humana com o tempo. É nessa construção, aliás, que estabelecemos a devida diferenciação e o necessário vínculo entre presente e passado, delineando a fisionomia de ambos. Indubitavelmente, conceber o passado é estabelecer uma unidade inteligível numa fração de tempo, que existe em função dos acontecimentos que a compõem, e a faz distinta de outra, a do tempo presente. O passado se constitui como tal quando entendido como "diferente o bastante" do presente "para saber que se trata de uma outra época" e, contudo, "semelhante o bastante para nos tornar cientes de nossa continuidade com ele". ${ }^{202}$

Há duas experiências suficientemente intensas para que o tempo vivido por Florestan Fernandes não seja mais o mesmo: a modernização em ritmo aceleradao, empreendida pelo regime militar, e o afastamento da instituição universitária, fruto do autoritarismo desse mesmo regime. A primeira impõe o reconhecimento da realização da modernidade econômica sem a superação dos arcaísmos seculares em outros âmbitos. A segunda é parte determinante de uma crise com relação a seus papéis diante disso. Nenhuma das duas circunstâncias encontra acomodação no interior das formulações teóricas de seu projeto acadêmico político, nem mesmo nas proposições esboçadas nos anos de sua estadia no Canadá.

Em suas recordações, os homens buscam ligar o "passado pessoal à memória coletiva e à história pública" ${ }^{203}$, por isso, entrelaçam-nas ao percurso de sua geração e às imbricações desta com o "passado coletivamente relembrado", de modo a poder compartilhar delas e mesmo validá-las, pois "acontecimentos que somente nós conhecemos são evocados com menos segurança e mais dificuldade. ${ }^{204}$ Nas longas entrevistas concedidas e nas inúmeras reconstituições autobiográficas elaboradas por Florestan Fernandes, de meados a fins dos anos setenta, o passado coletivo e individual é construído pelo presente, atravessado pelas duas experiências mencionadas, que, no cerne da diferenciação e do vínculo entre ambos, encerram o sentido de uma fração de tempo pretérita.

A enunciação em primeira pessoa, proeminente nesses depoimentos, recebe o alinhave sociológico de sua interpretação do Brasil recém concluída. Se o "passado só se coloca diante de nós se adquirir uma unidade suficiente para ser tomado enquanto tal" 205 - para Florestan

\footnotetext{
202 David Lowenthal, "Como conhecemos o passado", p. 90.

${ }^{203}$ Idem, p. 82.

${ }^{204}$ Idem, p. 81.

${ }^{205}$ Idem, p. 98.
} 
Fernandes, a revolução burguesa ilumina o sentido da história recente, inclusive o da sua. $A$ revolução burguesa no Brasil, colocando em xeque a forma anteriormente concebida de realização do projeto de modernidade, orienta o olhar sobre sua trajetória enquanto sociólogo, questionando sua própria proposta de inserção pública, elaborada em ligação íntima com aquela forma. Dessa maneira, a identidade intelectual é desconstruída e remodelada pari passu à reconfiguração das expectativas quanto à nossa modernidade, e se processa primordialmente através do exercício da reconstituição autobiográfica.

O amálgama entre a memória coletiva e pessoal e a força do presente na construção do passado se faria sentir na problemática que vincula e diferencia passado e presente - de que dá testemunho, a publicação que concentra esses depoimentos, A Sociologia no Brasil. Dividida em duas partes, "Os quadros de formação" e "Os quadros de ruptura", concentra na primeira, artigos dedicados às condições para implantação e consolidação das Ciências Sociais no Brasil, abordando da resistência cultural à racionalização aos recursos requeridos pela instituição para viabilizar a pesquisa. Na segunda, reúne fundamentalmente as memórias aqui analisadas. A obra parece materializar a ambivalência entre presente e passado, pois os distingue substancialmente e os unifica inevitavelmente. Publicar A Sociologia no Brasil é como organizar seu presente, construindo seu passado. ${ }^{206}$ Já em um dos textos mais conhecidos entre esses relatos, "A geração perdida”, fica saliente é a demanda que o presente confere à reflexão - através das seções que o compõem: "O que pretendíamos"; "Por que falhamos"; "Lições para o futuro". ${ }^{207}$ É flagrante o propósito de avaliação de erros do passado, que se presta ao diagnóstico do presente, como meios de uma finalidade última proposições para o futuro. Com efeito, o que é mais decisivo para os que se opõem ao regime, que a interpretação de sua derrota política; e o que é mais determinante para um intelectual à procura de sua identidade que a avaliação do seu projeto de intervenção no interior daquela derrota?

Eis o problema - pungentemente colocado pela década de setenta, na base dos marcos que balizam $A$ revolução burguesa no Brasil e suas memórias. Em seu encaminhamento, o autor demarca passado e presente, assumindo posições que o localiza nos debates sobre a democratização e a militância intelectual. O duplo movimento de retorno ao passado - na reelaboração de concepções em relação à modernidade nacional e na avaliação de seu projeto

\footnotetext{
${ }^{206}$ Haroldo C. Sereza também comenta o sentido da divisão da obra, mas com outra ênfase, p. 155.

207 “A geração perdida”. In.: A Sociologia no Brasil.
} 
de intervenção nela - tomado em sua dimensão autocrítica, é a matéria precípua do capítulo que iniciamos.

\section{$\underline{\text { 1. } A \text { revolução burguesa no pensamento de Florestan Fernandes. }}$}

Entre os quase dez anos que separam a idéia de uma obra sobre a revolução burguesa de sua conclusão, pode-se observar que o tema da modernidade, da sociedade de classes e do desenvolvimento do capitalismo no Brasil e na América Latina mobilizou grande parte de sua obra. Há, entretanto, um fator que distingue $A$ revolução burguesa no Brasil no conjunto dessa produção, e a torna central no pensamento do autor: a urdidura cerrada de elementos que até então se colocavam como cissuras esparsas no ideário acerca da modernidade na periferia que constava em seu projeto acadêmico político.

Urdidura possível por tratar das questões numa perspectiva histórica, cujo sentido é constituído no eixo da revolução burguesa, em sua acepção, um longo processo que vai do início do século XIX aos desdobramentos do golpe militar, caracterizado por três etapas do desenvolvimento capitalista - expansão do mercado capitalista, expansão do capitalismo competitivo e expansão do capitalismo monopolista. "Arremate" 208 este passível de apreensão pela noção de "modelo autocrático-burguês de transformação capitalista", que preside a transição e o desenvolvimento das três etapas definidoras da revolução burguesa. Com a mínima pretensão de apresentar a matriz das posições políticas que se desdobram desse tema-diagnóstico, a seguir esboçamos alguns dos sentidos impressos em seu percurso pelas conclusões a que chega a partir dessa noção.

Segundo Florestan Fernandes, há, no Brasil, entre transformação capitalista e dominação burguesa, uma dissociação entre desenvolvimento capitalista e democracia, resultante da forma típica de acumulação de capital nos quadros do capitalismo periférico e dependente. ${ }^{209}$ Essa (des)articulação no centro do conceito de "modelo autocrático burguês de desenvolvimento capitalista" indica que o desenvolvimento capitalista concilia "formas econômicas" "modernas", "antigas", e "arcaicas" - o que define seu tipo de "acumulação originária de capital", pois daí é extraída "parte do excedente econômico que financia a modernização econômica, tecnológica e institucional”. ${ }^{210}$ Mantendo assim, o passado vivo no

\footnotetext{
${ }^{208}$ Em feliz batismo de Maria Arminda do Nascimento Arruda. "Arremate de uma reflexão: $A$ revolução burguesa no Brasil de Florestan Fernandes”. Revista USP, n. 29. São Paulo, março/maio, 1996.

${ }^{209}$ A revolução burguesa no Brasil, p. 292.

${ }^{210}$ Idem, p. 269-270.
} 
presente, acorrentando a "expansão do capitalismo a um privatismo tosco, rigidamente particularista"211, a burguesia correspondente não universaliza a igualdade, mas a estabelece entre os privilegiados; segregando os tempos da modernidade social, econômica e política, privatizando o poder político. Conciliação proveitosa do mais novo com o mais arcaico que se repõe incessantemente - tudo se passa "como se o burguês moderno renascesse das cinzas do senhor antigo". 212

Estamos diante de formulações que não rompem com aspectos do projeto acadêmico político, mas detonam os as bases da interpretação da modernidade que o alicerçava. Por conta disso, esse esquema se tornará uma referência interpretativa totalizante: conjuntura política, Universidade, autoritarismo e processo de abertura democrática, intelectualidade engajada, todos serão vinculados ao referido esquema. A típica realização e concretização da revolução burguesa em países periféricos se faz presente na consideração de questões particulares como estas. São lapidares, inclusive, além dos textos de intervenção política escritos posteriormente à publicação dessa obra, os exaustivos prefácios e notas explicativas aos livros concebidos em momento anterior à concepção de revolução burguesa e republicados em fins dos anos setenta. Menos por suas informações factuais e mais pela metalinguagem preponderante, que, ao apresentarem suas elaborações pretéritas já num eixo auto-crítico, passam a subordinar a significação da obra à perspectiva então adotada em relação à modernidade. $\mathrm{O}$ uso dos prefácios como apresentação crítica e ressignificação das obras pretéritas se torna assíduo, especialmente após o "ensaio global introdutório" que a segunda edição de Mudanças sociais no Brasil recebe em 1974, e A Sociologia numa era de revolução social, em $1976 .{ }^{213}$

Definida a natureza do desenvolvimento capitalista como "autocrática", a sociedade aberta e democrática idealizada em seu projeto de modernidade cede lugar à constatação de que ela é aberta para a minoria que goza do privilégio de participar da modernidade; e fechada para a maioria eliminada das benesses trazidas por ela. Podemos arriscar, com autorização da mescla "bem temperada" do sociólogo-socialista, enunciar o desdobramento político da obra, deslocando os termos weberianos para os marxistas: a ordem social moderna no Brasil não é

\footnotetext{
${ }^{211}$ Idem, p. 167.

212 Idem, p. 168.

${ }^{213}$ Mudanças sociais no Brasil. Aspectos do desenvolvimento da sociedade brasileira. São Paulo: Difel, 1974, $2^{\mathrm{a}}$ ed; A Sociologia numa era de revolução social. Seus prefácios à $1^{\mathrm{a}}$ ed. são de 1960 e de 1962.
} 
democrática e aberta, senão para alguns; ou seja, a burguesia não realiza a revolução burguesa, não universaliza a igualdade. ${ }^{214}$

Em face das novas considerações, as alternativas até então visadas sociologicamente pelo autor, "revolução dentro da ordem" e "revolução contra a ordem", são rearticuladas. Com efeito, a obra tem lugar no interior do amplo movimento bibliográfico que, após o golpe militar, dedica-se à revisão de teses que apostavam num desfecho democrático para a querela entre o "Brasil moderno" e o "Brasil arcaico", e "vai procurar demonstrar que a revolução burguesa teria assumido uma forma conservadora, a partir de uma coalizão entre as elites modernas e as tradicionais, a qual teria conduzido o trânsito para a modernização". ${ }^{215}$ A conciliação vantajosa entre arcaico e moderno rouba a cena da dicotomia, que no constructo anterior se resolveria através da eliminação do primeiro pelo segundo. Torna-se indefensável a ação das esferas racionais na vanguarda da modernização, enquanto linhas de força capazes de eliminar a distância entre o país do futuro e o do passado, uma vez que entre eles, a inexorável combinação reproduz e sedimenta o modelo esquadrinhado.

$\mathrm{O}$ contraponto mais sutil ao projeto acadêmico político, face às novas conclusões, já sinaliza a areia movediça em sua base. A irrisão básica retoma mesmo ruptura já verificada para o período antecedente: supor que as deficiências de nossa modernidade peculiar pudessem ser eliminadas tendo por vanguarda a esfera científica. A base da suposição intelectuais, fundamento social para a síntese dos interesses distintos e particulares - está eliminada na medida em que uma classe particulariza a esfera pública da universalização e da igualdade, impede a moderna institucionalização dos conflitos, sinalizando com isso o necessário deslocamento do fundamento social da síntese. Se o espectro de preocupações que permeiam o projeto acadêmico, e as questões tratadas em seu exílio, estão presentes n' $A$ revolução burguesa no Brasil, quando tomadas nessa angulação, elas se vêem atravessadas por uma cisão essencial que não constava no antigo projeto: a noção de luta de classes no interior de uma revolução - perspectiva que preside a análise. Não é outra a razão pela qual no mesmo passo em que conceitue a revolução burguesa, delimite também a natureza e o imperativo da revolução socialista. Se a burguesia nacional não realizará a democracia

\footnotetext{
${ }^{214}$ A diversidade instrumental de Florestan Fernandes na construção de seu escopo teórico foi batizada por Gabriel Cohn, de "ecletismo bem temperado" - em texto de mesmo nome (In.: Maria A. D’Incao (org.). O saber militante). Maria Arminda do Nascimento Arruda chama a atenção para a "necessidade" da mescla entre a tradição marxista e weberiana na obra que nos ocupa; e o mesmo faz José de Souza Martins, ao prefaciá-la em sua $5^{\text {a }}$ edição. (Metrópole e cultura, p. 290; "Prefácio". In. A revolução burguesa no Brasil. São Paulo: Globo, 2006, $5^{\text {a }}$ ed., p. 21)

${ }^{215}$ Luiz Werneck Vianna, "A institucionalização das ciências sociais e a reforma social; do pensamento social à agenda americana de pesquisa", p. 204.
} 
moderna, uma vez que a dissociação entre desenvolvimento capitalista e democracia é intrínseca à natureza de sua revolução, e da ordem capitalista na periferia - passa a ser do proletariado a tarefa histórica de realização efetiva da democracia, e com ela a superação do próprio capitalismo. ${ }^{216}$ A transformação da igualdade universal num privilégio dos "mais iguais" leva à convicção de que a abertura desta ordem passa a ser tarefa revolucionária daqueles que se "classificam negativamente em relação a ela" 217.

Gabriel Cohn observa que Florestan Fernandes, em suas obras anteriores, estava preocupado com os "dilemas" da "democracia numa sociedade capitalista, numa sociedade burguesa em constituição, sem, em termos de sua preocupação científica, questionar a fundo essa sociedade enquanto capitalista, enquanto burguesa." ${ }^{218}$ Esse aspecto deve ser detido, pois será enquanto capitalista e enquanto burguesa que a sociedade brasileira será questionada e equacionada sociologicamente de forma negativa na obra em questão. Nesse sentido, A revolução burguesa no Brasil não consiste em sociologia por um lado e socialismo por outro. Trata-se de sociologia e socialismo num mesmo universo de sentido e concepção de obra. Amálgama, aliás, confesso: "trata-se de equacionar, sociologicamente a negação de um presente indesejável”. ${ }^{219}$ De maneira que, o socialismo, opção política subjetiva e individual ganha corporificação teórica na obra em que a compreensão da revolução burguesa típica dos países capitalistas dependentes dá a chave de compreensão para a revolução socialista possível e necessária nesses contextos.

Por conseguinte, o equacionamento sociológico da negação da ordem capitalista promove uma espécie de autorização sociológica ao socialista, conferindo estatuto diferenciado à posição política do autor, até então alçada no plano da escolha política estritamente pessoal. Está em jogo uma dimensão que diz respeito ao distanciamento de posturas como aquelas que cindiam as análises do sociólogo das convicções do socialista como em momentos nos quais a ética dita o dever de esclarecimento a ser prestado a todos os grupos de contestação, contraposta a seus posicionamentos políticos individuais, e mesmo contrariando-os. Assim, não são poucas as declarações do tipo - como "adepto do socialismo,

\footnotetext{
216 Para uma análise da problemática do conceito de "contra-revolução" na obra, conta-se com o terceiro capítulo da leitura de fôlego de Carlos Águedo Nagel Paiva, Capitalismo dependente e (contra)revolução burguesa no Brasil: um estudo sobre a obra de Florestan Fernandes. Campinas: Unicamp, Instituto de Economia, dissertação de mestrado, 1991.

${ }^{217}$ A revolução burguesa no Brasil, p. 331. A relação entre a delimitação da natureza da revolução burguesa e a compreensão da revolução socialista, fica patente na reincidente contraposição entre revolução democrática/ revolução socialista e conciliação autocrática, vínculo sinalizado por Octavio Ianni, "Introdução", p. 29.

${ }^{218}$ Gabriel Cohn, "Padrões e dilemas: o pensamento de Florestan Fernandes", p. 135- 136.

${ }^{219}$ A revolução burguesa no Brasil, p. 10.
} 
todas as minhas preferências pessoais encaminham-se no sentido de destruir a ordem social que engendra, perpetua e revigora essa modalidade monstruosa de poder conservador", contudo, "limitei-me a travar os debates" em torno de como a questão "se coloca na ordem social existente e como ela poderia ser solucionada dentro dela." 220 O dever de esclarecimento dos grupos de contestação que se ativessem à ordem é deslocado pelo dever de denúncia dos limites da contestação dentro da ordem - movimento mais intenso no período final a de que se ocupa esse estudo.

Florestan Fernandes ancora-se crescentemente, num esquema cerrado de interpretação em que socialista e sociólogo se tornam um só, e suas análises correspondem a essa síntese, sem que, contudo, a combinação o satisfaça. Ao contrário, evidencia suas inquietações quanto a ela. A eliminação da cisão entre ambos se dá pela conjugação de problemáticas de um e outro, pensando juntos A revolução burguesa no Brasil, bem como pelas frustrações do socialista, que encontram revérbero no que passa a ser considerado equívoco do sociólogo, experiência na base de uma afirmação como: "Trata-se de um ensaio livre, que não poderia escrever, se não fosse sociólogo. Mas que põe em primeiro plano as frustrações e as esperanças de um socialista militante". 221

Porém, a mescla entre frustração e equívoco não se compreende sem que se apreenda as duas tradições teóricas em jogo - sociologia clássica e marxismo clássico - com as quais estabeleceu vínculos igualmente indeléveis em momentos distintos de sua trajetória: a primeira, oriunda de sua formação universitária e a segunda, do exílio a que se viu legado quando foi desabrigado do seio da instituição que presidiu tal formação. Não se esgotam as dimensões d'A revolução burguesa no Brasil sem que se apreenda o significado dessa dupla presença - signo da ambivalente abertura dialógica da obra - que se remete tanto ao meio intelectual quanto ao meio político, vindo à lume em momento que diz muito a ambos. Nesse duplo diálogo, os dois âmbitos cindem e agregam passado e presente - nas expectativas frustradas do sociólogo, nas veleidades sufocadas do socialista. Vale ressaltar que, a esse aspecto não passa incólume o próprio Florestan Fernandes, já à época da publicação.

É certo que, atualmente, A revolução burguesa no Brasil é apresentada com freqüência, como sua opus magnum. Também é indiscutível que a obra o recoloca no debate intelectual e político - sendo mesmo exemplar o colóquio, organizado em Austin, por Carlos Guilherme

\footnotetext{
${ }^{220}$ A universidade brasileira: reforma ou revolução?, p. 9. Ver também: "Sociologia, modernização autônoma e revolução social”, p. 153-154; e A condição de sociólogo. São Paulo: Hucitec, 1978, p. 154.

${ }^{221}$ A revolução burguesa no Brasil, p. 3-4.
} 
Mota e Fred P. Ellison, da Universidade do Texas - em que estiveram debruçados sobre a problemática da obra, Emília Viotti da Costa, Paulo Silveira, Juarez Rubem Brandão Lopes, entre outros, e para os quais o autor elabora uma "Resposta às intervenções: um ensaio de interpretação sociológica crítica". ${ }^{222}$ Contudo, ao tempo de sua concepção, o retorno triunfante ao debate público não compensava com reconhecimento que lhe abrilhantasse, a sensação de isolamento intelectual e político. Ao contrário, as controvérsias promovidas pela obra - tão tocantes no prefácio à segunda edição - estão no cerne de uma incompreensão desoladora para o autor. É válido tomar suas palavras, que denotam em alguma medida a consciência precisa, ainda que não necessariamente uma estratégia consciente, da dupla abertura dialógica que assinalamos. Em carta, confessa que uma de suas ocupações consiste em "descobrir o que acham do último livro. Os comentários verbais têm sido decepcionadores; e o que sai em jornais e revistas vai pelo mesmo teor". A razão para tal é cogitada: “já não existe uma boa cultura geral. Poucos leram os clássicos do socialismo e entre esses, acho que ninguém possui treino sociológico. É uma pena", precisa "de muita paciência para suportar, ao lado da marginalização, uma incompreensão generalizada". ${ }^{223}$ Tem realce a insatisfação do autor quanto à recusa por não entendimento, possivelmente por parte dos dois meios a que, paradoxalmente se dirigem suas formulações.

Mais aspectos devem ter destaque para que vínculos e distanciamentos entre passado e presente, bem como essa dupla abertura, sejam aventados. A historicidade interna ao desenvolvimento da obra, permite compreender A revolução burguesa no Brasil como desdobramento de velhas preocupações do autor. É saliente o parentesco entre a reflexão que se "arremata" na obra sobre a revolução burguesa e a problemática que se elabora em $A$ integração do negro na sociedade de classes. ${ }^{224}$ José de Souza Martins, atentando à adoção da perspectiva social dos "de baixo" nessa obra, assegura que "no modo dramático e subalterno como se dá a integração do negro no novo regime decorrente da abolição da escravatura", ele “ encontra a referência social adequada para a leitura sociológica do desenvolvimento do capitalismo no Brasil." 225

Com efeito, a problemática da constituição da modernidade no Brasil se faz muito presente na primeira e na segunda partes de A revolução burguesa no Brasil, tendo ênfase os

\footnotetext{
${ }^{222}$ As comunicações estão reunidas em Encontros com a civilização Brasileira, n. 4. Rio de Janeiro, Outubro 1978.

${ }^{223}$ Bárbara Freitag, "Florestan Fernandes por ele mesmo", p. 159.

${ }^{224}$ A integração do negro na sociedade de classes. São Paulo: Dominus/Edusp, 1965, 2v.

${ }^{225}$ Florestan, Sociologia e consciência social no Brasil. São Paulo, Edusp, 1998, p. 27.
} 
obstáculos para sua realização. ${ }^{226}$ Gabriel Cohn sintetizou as vicissitudes que enfrenta o autor, como "padrões e dilemas", que se manifestam analiticamente na detecção da ausência de determinados agentes e na emergência de outros, para os quais a expectativa sociológica de conjugação racional entre atores e oportunidades nem sempre encontra respostas. Programaticamente, elas se colocam na preocupação quanto à criação do suporte de uma ordem social moderna e da intervenção racional orientada no sentido de "modificar as condições de emergência de determinados tipos de homem". ${ }^{227}$ A análise sociológica que identifica dificuldades e debilidades na formação da ordem social moderna aberta e democrática se presta à elaboração de um programa de intervenção social que se dirija concomitantemente à alteração da ordem que não origina seus agentes ideais, e à formação e educação dos agentes para aquela ordem. Preocupações definidoras do estudo do tipo de integração que o egresso da escravidão teve na emergente sociedade de classes - pois ela "não transformou o negro em cidadão", delegando a ele "recanto escuro da sociedade, os lugares de ajustamento precário e anômico" 228 - que ratificam sua perspectiva de intervenção sociológica e educacional para a formação do sujeito moderno propriamente dito, contra o drama dessa história ímpar, que não desenvolve as possibilidades inscritas em sua transformação. O tom da obra revela, contudo, certo "ceticismo quanto à superação da marginalidade social dos egressos da escravidão, questão decisiva à constituição da sociedade moderna." 229

A revolução burguesa no Brasil é, indubitavelmente, fruto de sua perseguição obstinada à peculiaridade brasileira. Essa característica permite compreendê-la no interior da tradição de nosso pensamento social, pela afinidade que estabelece com que uma de suas clássicas questões, a "gênese da sociedade brasileira". ${ }^{230}$ Esse adentrar do autor em questão que dá ritmo ao "pensamento das diferentes gerações de pensadores brasileiros" ${ }^{231}$, se tem como eixo a revolução burguesa, desdobra-se certamente de $A$ integração do negro na sociedade de classes, cuja questão central, o agente e a ordem social, leva a pensar o modelo de formação da ordem moderna típicos de sociedades como a nossa. Contudo, como é certo

\footnotetext{
${ }^{226}$ Para uma exploração da relação entre as partes da obra, ver a reflexão de Maria Arminda do Nascimento Arruda (Metrópole e cultura, p. 266-298); e o prefácio de José de Souza Martins.

${ }^{227}$ Gabriel Cohn, "Padrões e dilemas: o pensamento de Florestan Fernandes", p. 147-148.

${ }^{228}$ Florestan, Sociologia e consciência social no Brasil. São Paulo, Edusp, 1998, p. 27.

${ }^{229} \mathrm{Idem}$, p. 265-266. Acerca das imbricações assinaladas, ver também as reflexões de Élide Rugai Bastos e João Batista Borges Pereira, "A questão racial e a revolução burguesa" e "Raça e classe social no Brasil". In.: Maria A. D'Incao (org.). O saber militante.

${ }^{230}$ Maria Arminda do Nascimento Arruda, Metrópole e cultura, p. 266.

${ }^{231}$ Fernando Novais e Maria Arminda do Nascimento Arruda, "Revisitando os intérpretes do Brasil". In.: Fernando Novais. Aproximações: ensaios de história e historiografia. São Paulo: Cosac Naify, 2005, p. 266.
} 
que "em momentos cruciais há uma tendência a reinterpretar o Brasil" ${ }^{232}$, a peculiaridade da formação é requerida enquanto "revolução burguesa", e num estilo em alguma medida alheio àquele no qual se empenhou por instaurar e rotinizar em nossa vida intelectual. Para Maria Arminda do Nascimento Arruda, as investidas de Florestan Fernandes "contra o ensaísmo", uma "contraface da adesão aos pressupostos da ciência empírica - abrandaram-se no decorrer dos anos" - sendo o subtítulo de A revolução burguesa no Brasil, Ensaio de Interpretação Sociológica, "revelador do recuo crítico frente ao ensaio" e testemunho da "admissão da forma ensaística ao lado da sociologia", indicando também "a natureza pouco sistemática da reflexão". 233

Eis o esboço do caminho reflexivo, que, entre os anos 1964 e 1974, da defesa d'A integração como tese de cátedra à conclusão d'A revolução, transforma aquele ceticismo em base de uma convicção sociológica acerca da impossibilidade de abertura universal da ordem no interior dela mesma. Dessa maneira, "no ambiente intelectual do debate brasileiro sobre o tipo de sociedade capitalista que estava se desenvolvendo no Brasil" ${ }^{234}$ - o livro ganha voz e faz "um acerto de contas com alguns aspectos das grandes interpretações do próprio grupo de Florestan e do próprio Florestan, e também das esquerdas brasileiras."235

É nesse sentido que se delineia a dupla abertura da obra, ao meio político e intelectual, figurada na mescla entre sociólogo e socialista. Com o enquadramento de sua problemática sociológica numa perspectiva histórica que define a natureza da revolução burguesa e da burguesia que presidem a modernidade em questão, Florestan Fernandes adentra um terreno especificamente político do debate intelectual em meados dos anos setenta - que diz respeito às teses centrais de uma esquerda derrotada, em busca de sua reconstituição. ${ }^{236}$ Para Marcos Del Roio, a concepção do livro é marcada "pelo influxo da revolução cubana e da derrota de 1964", bem como pelas "circunstâncias da crítica da teoria da revolução nacional democrático-burguesa subjacente à ação política do PCB”. Convergindo, com o conjunto das críticas "para a negação da hipótese de um passado feudal" e "da existência de uma facção burguesa que servisse de protagonista da revolução nacional e democrática". ${ }^{237}$ Assim, se a

\footnotetext{
${ }^{232}$ Fernando Novais, Aproximações, p. 390.

${ }^{233}$ Maria Arminda do Nascimento Arruda, Metrópole e cultura, p. 315.

${ }^{234}$ José de Souza Martins, "Prefácio", p. 10.

${ }^{235}$ Idem, p. 16.

${ }^{236}$ O que se verifica no depoimento de Jacob Gorender: “A revolução burguesa e os comunistas.” In.: Maria A. D'Incao (org.). O saber militante.

237 “A teoria da revolução brasileira: tentativa de particularização de uma revolução burguesa em processo". In.: João Quartim Moraes e Marcos Del Roio. História do marxismo no Brasil. Visões do Brasil, v. IV. Campinas: Unicamp, 2000, p. 108.
} 
gênese da reflexão retoma $A$ integração do negro na sociedade de classes, e o diálogo com os pares do meio acadêmico, os fatores externos que a convocam estabelecem diálogo com o espectro de esquerda então derrotado, ao propor uma definição da própria revolução burguesa - discordando sensivelmente de noções que orientaram as práticas dessa esquerda no passado. Nesse sentido, a obra se aproxima mesmo de uma síntese entre o passado do scholar comprometido e o presente do intelectual em redefinição - o que se pode apreender ao ter em mira, além da linhagem sociológica já assinalada, a emergência do marxismo clássico no constructo da obra magna. Com efeito, uma das dimensões de A revolução burguesa no Brasil no pensamento de Florestan Fernandes consiste na efetiva incorporação de Lênin, no interior do raciocínio teórico. Convém por isso, sinalizar aspectos dessa imbricação complexa, com o intuito de salientar o diálogo estabelecido no campo do político.

A terceira parte, redigida após seu retorno do Canadá, é característica dessa incorporação. ${ }^{238} \mathrm{O}$ modelo de desenvolvimento capitalista é pensando segundo um padrão de acumulação vinculado à problemática do imperialismo. ${ }^{239}$ Por isso, menos "Marx e mais Lênin" ${ }^{240}$ dirige a análise, principalmente, na medida em que os impasses da formação moderna são esquadrinhados enquanto peculiar revolução burguesa, cuja conseguinte política é o deslocamento das tarefas revolucionárias da burguesia para o novo proletariado, agente que consta entre as virtualidades da história in flux. Dissociação entre classe e natureza da revolução que remete à delimitação de tarefas revolucionárias em registro leninista, aspecto que se mescla ao do equacionamento especificamente sociológico, da relação entre socialismo e democracia, tanto em seu aspecto social, no sujeito histórico de sua realização; quanto em seu aspecto político, tendo no socialismo $a$ alternativa para realização da democracia. Assim, fica encaminhada ainda, a difícil questão nacional, pois a saída encontrada à autocracia burguesa, "é a retomada da revolução nacional e democrática, que, como sujeito histórico, tem a grande massa de despossuídos e marginalizados, aglutinada em torno da classe operária" - revolução essa que, dentro das "condições da autocracia burguesa vigente no capitalismo monopolista dependente" confronta-se, "desde o início" com "a burguesia e o imperialismo", identificando-se à "marcha da revolução socialista."241

\footnotetext{
${ }^{238}$ Encontra-se esse relato em Bárbara Freitag, "Florestan Fernandes por ele mesmo", p. 158.

${ }^{239}$ Maria Arminda do Nascimento Arruda, Metrópole e cultura, p. 272.

240 José de Souza Martins, "Prefácio", p. 21.

${ }^{241}$ Marcos Del Roio, "A teoria da revolução brasileira: tentativa de particularização de uma revolução burguesa em processo", p. 114.
} 
Entre sua compreensão do perfil e da contribuição teórica de Lênin, apresentada anteriormente, e a concepção da obra em questão há inúmeras aproximações - e elas não dizem respeito apenas às categorias teóricas que conformam a problemática e os dilemas das "revoluções de caso não clássico". Se concorre para a retomada da obra, os incentivos que recebeu de amigos e familiares ${ }^{242}$, não se pode desprezar a inspiração promovida pela figura de Lênin. Diversos aspectos a sinalizam.

Não por acaso, para José de Souza Martins, A revolução burguesa no Brasil é equivalente a $O$ desenvolvimento do capitalismo na Rússia, "um marco nos estudos sobre o desenvolvimento do capitalismo em sociedades diferentes das sociedades da Europa Ocidental." ${ }^{243}$ No entendimento de Florestan Fernandes, essa obra dava a Lênin a chave interpretativa do desenvolvimento histórico de seu país, condição sine qua non de um entendimento preciso da conjuntura política que conferisse eficácia à ação política. É possível que, tal como Lênin, buscasse Florestan Fernandes uma reflexão dessa natureza.

Da mesma maneira, o destaque para a consideração luta de classes, enquanto problema político central da sociedade de classes remete à sua própria definição de marxismo-leninismo, como vertente que deslocou "o âmago do marxismo para a reflexão política", enquadrando "as relações de classe como relações de poder". 244 A "luta de classes", enquanto relação especificamente politica, delimita revolução burguesa - uma vez que é a articulação entre dominação burguesa, no âmbito político, e modelo de transformação capitalista, no âmbito econômico, que define a sua singularidade - da qual, aliás, são extraídas as tarefas históricas do proletariado, de acordo com o que representa para ruptura do modelo autocrático de desenvolvimento capitalista. ${ }^{245}$

Outrossim, assinala-se, indubitavelmente, no interior do livro, e a partir de então, na problemática desenvolvida pelas análises do autor em geral, a passagem de um eixo central de sentido a outro: de modernidade à revolução. Se deslocamentos e hesitações no que tange à adoção de termos, modernização ou (contra) revolução, podiam ser observados já nas considerações acerca das relações entre intelectuais e regimes militares elaboradas no Canadá,

\footnotetext{
${ }^{242}$ A revolução burguesa no Brasil, p. 3.

243 "Prefácio", p. 17-18.

244 "Introdução", p. 13-17.

${ }^{245}$ Do ângulo da Sociologia é possível se pensar num enquadramento do tipo "sociológico e político", conforme Brasílio Sallum Jr. "Notas sobre o surgimento da Sociologia Política em São Paulo". Política \& sociedade. Revista de sociologia política, n. 01. Florianópolis: Cidade futura, 2002; ou sócio-político, conforme Gabriel Cohn "Florestan Fernandes - A Revolução Burguesa no Brasil". In.: MOTA, Lourenço Dantas (org.). Introdução ao Brasil. Um banquete no trópico, v.I. São Paulo: Senac, 1999.
} 
a partir de então, parece definitiva a incorporação de "revolução" enquanto problemática definidora de uma perspectiva. Essa clivagem se expressa teoricamente através do trânsito de Mannheim a Lênin, e tematicamente através da busca por um agente ausente a outro conforme arguta menção de Gabriel Cohn. Eis o drama: tudo se passa como se a peculiaridade da floração burguesa delegasse tarefas adicionais à revolução socialista, mas também não originasse o agente histórico para tal tarefa. $\mathrm{O}$ sociólogo que não encontrava "o agente social capaz de impulsionar o capitalismo, quer dizer, a burguesia", depara-se com a correspondente debilidade no que tange à formação política alternativa ao capitalismo, "o partido revolucionário". ${ }^{246}$ Sociólogo e socialista não encontram os agentes de sua obstinada procura. Encontram, contudo, nas debilidades crônicas da formação da ordem que não forja seu próprio agente protagonista, a força selvagem de sua perpétua vigência através do aborto das forças sociais e políticas alternativas a esta ordem. Dupla frustração, pois sociólogo e socialista pensam juntos A revolução burguesa no Brasil.

Quando o sociólogo adentrasse o terreno especificamente político do debate sobre o desenvolvimento do capitalismo e as possibilidades de uma ruptura revolucionária, seria ele também invadido por esse terreno. A ambivalência instaura uma nítida dualidade de parâmetros - o científico e o político - que se manifesta no deslocamento teórico e temático assinalados. Por conseguinte, ocorrem alterações na vertente intervencionista de seu projeto acadêmico político. Entretanto, antes transferi-la da "educação para a política"247, é no âmbito de sua autoavaliação que essa ambivalência se faz significativamente presente, pois, se as formulações, nos anos cinqüenta e sessenta, tinham por referência o meio científico, têm agora também o meio político, e sofrem, por conta disso, um crivo de avaliação a que não estiveram sujeitas, oriundo de um terreno a que eram relativamente alheias no passado. A mescla entre confíssão pessoal e consciência histórica - numa declaração como: "não consegui superpor os dois papéis que gostaria de preencher", pois "gostaria de ser um cientista social ao mesmo tempo vinculado com a universidade e com o socialismo. Todas as tentativas que fiz para combinar as duas coisas falharam"248 - deixa entrever que nas considerações acerca de seus papéis de socialista e sociólogo, encontramos a proeminência mais significativa disso. Vejamos.

Pelo que já foi exposto, fica patente que há um complexo e bem sucedido amálgama entre socialismo e sociologia, socialista e sociólogo, na concepção d'A revolução burguesa no

\footnotetext{
246 "Padrões e dilemas: o pensamento de Florestan Fernandes", p. 144.

${ }^{247}$ José de Souza Martins, "Prefácio", p. 15.

${ }^{248}$ A condição de sociólogo, p. 77.
} 
Brasil. Por isso, é válido supor que a insatisfação quanto à "superposição de papéis" se encontre em outro plano que não o teórico: "aparece por causa da minha tentativa persistente de enlaçar a sociologia como ciência, ao socialismo como movimento político revolucionário". ${ }^{249}$ Simples e precisamente, o autor sinaliza $o$ quê do socialismo e $o$ quê da Sociologia tem em vista. O problema não está exatamente na difícil síntese entre socialismo e sociologia, mas numa impossível combinação entre sociólogo e militante político, entendendo-a como vinculação capaz de estabeler uma intervenção especificamente socialista na sociedade. Não é casual que já se tenha afirmado sobre o autor: "uma crítica que não se pode fazer", é "que se contente com palavras". 250

Para o autor seria necessário "que o próprio movimento socialista adquirisse maior força e outra lucidez na compreensão dos papéis dos intelectuais e na vinculação de suas atividades específicas ao fomento do pensamento socialista revolucionário". ${ }^{251}$ Chega mesmo a esboçar como seria esse movimento socialista, através da comparação com a Rússia em décadas anteriores à revolução - quando os movimentos socialista, anarquista e sindicalista "criavam papéis intelectuais específicos", e os intelectuais constituíam "um forte movimento de elaboração criadora da imaginação política revolucionária." ${ }^{252}$ Esse ideal se dirige às possibilidades de formação de quadros intelectuais próprios, num movimento socialista vigoroso - aspecto que emerge como mais uma de nossas fragilidades: "apenas a ordem existente logrou formar os seus 'intelectuais orgânicos'., ${ }^{253} \mathrm{E}$ coloca a derradeira questão: “O que significa, para nós, essa debilidade congênita, que converte os sociólogos automática e inevitavelmente, em 'intelectuais orgânicos da ordem'?"254

Condição paradoxal esta, em que as debilidades de formação da modernidade lega papéis adicionais a seus agentes, mas os constitui frágeis demais para a realização de suas tarefas históricas mínimas. A concepção de uma modernidade precária conferia ao intelectual uma sobrecarga de tarefas - cujo fim seria sanar as debilidades da formação social, expressa cabalmente em A Sociologia numa era de revolução social, cujas recomendações impunham aos cientistas sociais que substituíssem a própria experiência histórica que generalizou e

\footnotetext{
${ }^{249}$ A natureza sociológica da Sociologia. São Paulo: Ática, 1980, p. 15.

${ }^{250}$ Gérard Lebrun. "O Brasil de Florestan Fernandes". In.: Maria A. D’Incao (org.). O saber militante, p. 263.

251 "Em busca de uma sociologia crítica e militante", p. 208.

${ }^{252}$ A condição de sociólogo, p. 153.

253 "Em busca de uma sociologia crítica e militante", p. 207. O distanciamento de Florestan Fernandes em relação às elaborações de Antonio Gramsci impede a associação que o uso de "intelectual orgânico" pode sugerir, e é empregado aqui no sentido de "produção de quadros próprios" em oposição aos "de fora" do movimento socialista.

254 “Em busca de uma sociologia crítica e militante", p. 204.
} 
rotinizou a racionalização e a secularização nas sociedades da "modernidade originária". ${ }^{255}$ Contudo, se as debilidades da formação social creditam um excesso de funções aos cientistas, o subaproveitamento dos mesmos é tributado também a essas mesmas debilidades - e, portanto, "concretamente", em se tratando "de uma sociedade de classes, nenhuma geração pode compensar por si mesma, as debilidades dos conflitos de classes". ${ }^{256}$ A despeito da vida intelectual ser tomada do ângulo da natureza dessa revolução burguesa, a intelligentsia, que desempenhava no constructo de inspiração mannheimiana o papel de uma "garantia estrutural da validade ${ }^{, 257}$, não recebe seu decorrente substituto lógico - ausente que este se encontra politicamente. Substituição em suspenso, verificada na perda do protagonismo intelectual e na convocação à perspectiva socialista marcadas pela ausência de um novo suporte social para a síntese. Daí que a crítica seja impiedosa, mas não forneça a base para um outro perfil de produção de conhecimento ou intervenção intelectual. O passado ainda não é morto e o futuro ainda não é vivo. A passagem de Mannheim a Lênin é significativa, no entanto, não permite a adoção de um novo perfil intelectual, nem oferece nova base para a síntese, sem que o autor retorne a Marx - que lhe oferecerá teoricamente aquele substituto, e não sem que este se manifeste no curso da história in flux, como veremos.

O distanciamento com relação a afirmações típicas em suas obras desde os anos sessenta deve ser demarcado. O autor entende que seu antigo envolvimento, "no que concerne ao movimento trotskista" e às várias tendências da Campanha pela Escola Pública foram-lhe "produtivas e fecundas". ${ }^{258}$ Contudo, esse "rendimento" para a ciência, que até então justificava a adesão à agenda política da sociedade, torna-se insuficiente. A questão não é mais o salto científico dado em razão do envolvimento, mas o "que o movimento socialista poderia e deveria fazer, para consolidar-se, expandir-se e gerar quadros intelectuais próprios, essa é a questão." ${ }^{259}$ A problemática diz respeito primordialmente a uma ordem que não engendra movimentos "contra a ordem" com intelectuais próprios, e, por não comportar forças contrárias, converte todas as possíveis subversões em forças de sua manutenção.

Assim, a "debilidade de formação", que responde pela inexistente criação de quadros próprios do movimento socialista, é contrapartida da força da ordem que impede a

\footnotetext{
${ }^{255}$ A Sociologia numa era de revolução social, p. 76-77.

256 “A geração perdida", p. 239.

${ }^{257}$ Michael Lowy. As aventuras de Karl Marx contra o Barão de Müchhausen, p. 86.

258 "Em busca de uma sociologia crítica e militante", p. 208.

${ }^{259}$ Idem.
} 
instrumentalização do intelectual formado por outra instância social. Para o autor, a debilidade congênita da formação está na base, tanto de uma não intrumentalização dos intelectuais; quanto da não formação de seus intelectuais contra a ordem a partir dos movimentos contestatórios. Por isso, lamenta tanto sua "não instrumentalização", quanto o abandono do movimento trotskista de que participou nos anos quarenta, pois não tinha “como ser sociólogo através e dentro do movimento". ${ }^{260}$ E chega a considerar que se algo similar ao quadro russo pré-revolucionário houvesse no Brasil, dele teria sido exigido, pelo movimento socialista, que na Universidade, explorasse a "imaginação política revolucionária"261 - ainda que assegure, concomitantemente, "que uma atividade militante intensa é incompatível com a vida acadêmica"262, em flagrante oscilação, típica de reflexões em curso, mas também de sua dificuldade em definir a ideal de relação entre intelectuais, sociedade e política.

Ancorada nessa noção de debilidade, e em inúmeras outras contradições, a lamentação não o leva a adotar uma das propostas em jogo para a constituição do pensamento revolucionário - intrumentalização, tal como prescrito no Canadá, ou produção de quadros próprios. Nos depoimentos, a ausência de ambos em sua experiência propicia que pense na validade das duas hipóteses. A fraqueza do movimento socialista realça a força de uma débil ordem burguesa, pois parece exclusividade dela, o uso social dos intelectuais - tanto a partir da produção de seus quadros próprios, quanto a partir da apropriação dos de instâncias diversas, inclusive, dos dissidentes, "usados, mesmo quando cumprem zelosamente as suas tarefas". ${ }^{263}$ Ainda em tela, as frustrações do socialista e do sociólogo.

Mas a concomitância dessas frustrações não responde à questão subterrânea: o que representa diante disso um projeto acadêmico político que tem por nervura central o intelectual moderno e por utopia última a constituição de uma modernidade plena? Pois entre as debilidades da ordem moderna, destaca-se a inviabilidade dessa típica personagem. Fazer emergir essa questão é argüir acerca da congruência entre a adoção da ruptura com a ordem no plano político e a elaboração de uma proposta de atividade intelectual que se afine com tal rompimento. Respondê-la é necessariamente empreender uma autocrítica. Florestan Fernandes não se furta a ela. Eis o tema da próxima seção.

\footnotetext{
${ }^{260}$ Idem.

${ }^{261}$ A condição de sociólogo, p. 153-154.

${ }^{262}$ Idem, p. 68.

263 “A geração perdida”, p. 219.
} 


\section{O passado revisitado: entre o não ser mais e o vir a ser.}

Há várias dimensões que os depoimentos de Florestan Fernandes podem tomar enquanto fontes para análise de sua trajetória. Numa proposta que queira apreender os nexos entre sua interpretação global da sociedade e a delimitação de um perfil intelectual, ressaltando a historicidade da imbricação entre esses termos, o aspecto de elaboração da memória consiste em eixo heurístico de análise. Pois, "o passado relembrado diverge substancialmente da experiência original" ${ }^{, 64}$ e a narrativa da memória "transmuta experiência, destila o passado em vez de simplesmente refleti-lo" ${ }^{, 265}$. Signo melhor desse processo não haveria, senão a proliferação dos textos com teor memorialista na obra de Florestan Fernandes.

Estabelecer a fisionomia do passado é também desenhar a própria fisionomia no presente. Por isso, seus depoimentos podem ser entendidos como uma forma de reestabelecer os referenciais de sua identidade intelectual. Afinal, retomar o "passado é crucial para nosso sentido de identidade: saber o que fomos confirma o que somos", e a recordação "nos liga a nossos selves anteriores, por mais diferentes que tenhamos nos tornado". ${ }^{266}$ Assim, é central na configuração da identidade, a versão pessoal acerca do próprio passado ${ }^{267}$ - razão pela qual, a de Florestan Fernandes é nossa matéria-prima nesta e na próxima seção.

É factível que, dentro de seu esquema interpretativo, a inviabilidade de realização plena da modernidade desdobre-se na irrealização da intelligentsia. Como fruto de uma ordem agenciada por uma burguesia que "solta à sua sorte" não "tem como ser democrática, mas sempre estará sob o encanto da solução autocrática"268, "a intelligentsia, por mais crítica e militante que seja, ou submerge no movimento socialista revolucionário, se este existir, ou se condena a viver como farsa a tragédia da burguesia nacional" ${ }^{269}$ Os impulsos de formação do intelectual moderno parecem enforcados pelos desajustes com relação às promessas da revolução burguesa clássica. Resulta daí, uma intelligentsia sujeita a condições igualmente singulares de constituição - concepção evidente em aparente defesa do cientista social: “(os que) criticam o intelectual e esperam demais dele", ignoram que "ele próprio, possui as

\footnotetext{
${ }^{264}$ David Lowenthal, "Como conhecemos o passado", p. 101.

${ }^{265}$ Idem, p. 94.

${ }^{266}$ Idem, p. 83.

${ }^{267}$ Propósito que anuncia na apresentação de “A geração perdida”, p. 216.

${ }^{268}$ Gabriel Cohn, "Florestan Fernandes - A revolução burguesa no Brasil”, p. 412.

269 “A geração perdida”, p. 232.
} 
mesmas limitações". ${ }^{270}$ Defesa apenas aparente, pois, para o autor, o "que está em jogo" é "explicar por que uma ordem social burguesa, na periferia do mundo capitalista, enfrenta na esfera cultural as mesmas impossibilidades que se concretizam na esfera econômica". ${ }^{271}$ Nessa esteira, estabelece-se uma precariedade recíproca, entre intelectuais e forças de contestação à ordem, através dos interditos que lhes são impostos. O problema de base remete àquela adição de tarefas à intelligentsia, em razão de uma modernidade precária, ainda que destinada a se realizar. O aborto dessa promessa lança os intelectuais na condição de precariedade idêntica à da ordem social, e, portanto, a das classes sociais. Daí resulta ainda, alguma identidade entre a derrota política dos "de baixo" e a dos intelectuais - ratificada nos desdobramentos do golpe militar em 1964, pelos quais não foram tolerados seus respectivos ideais e reivindicações. ${ }^{272}$

Eis seu problema, em suma: por que "as burguesias conquistadoras", "conseguiram usar a intelligentsia crítica e militante de suas sociedades em processos de revolução democrática?" - esse processo seria uma "necessidade histórica em algumas sociedades" e uma "aberração ou mesmo um ponto final ao próprio capitalismo em outras"? ${ }^{273}$ Não por acaso, o enquadramento da experiência intelectual no esquema interpretativo d'A revolução burguesa no Brasil, ocorre prodigamente na demarcação da gênese, desenvolvimento e destinação histórica do grupo identificado como "geração perdida" ${ }^{274}$, núcleo através do qual o autor se relaciona com a instituição universitária e com a sociedade, e que atravessa toda a avaliação do passado, remetendo-o a seus pares pretéritos e presentes. Por esta razão, "a geração perdida" está no centro dessa apresentação.

A formação do grupo responde a um duplo deslocamento: um descompasso com relação à sociedade, e um isolamento com relação ao conjunto da instituição. Trata-se de uma dupla relação negativa, diante da qual se vê a pretensão à formação de uma intelligentsia, e de um desencontro típico da proposição do moderno num meio hostil a ele. Assim, a afirmação do grupo, pela via da instituição universitária e dos valores que encampava, "não deitava

\footnotetext{
${ }^{270}$ A condição de sociólogo, p. 153.

271 "A geração perdida", p. 230.

${ }^{272}$ Essa identidade da "derrota" fomenta, ulteriormente, no interior da intelligentsia como um todo, a busca por uma correlata identidade na luta política. Excelente reflexão acerca desse problema encontra-se em Edgar de Decca, 1930. O silêncio dos vencidos. São Paulo: Brasiliense, $7^{\mathrm{a}}$ ed., 1997 (o texto é de 1979).

273 "A geração perdida", p. 231.

${ }^{274}$ Essa identificação refere-se ao que no Canadá era denominado por "intelligentsia". Diversos nomes, contudo, são utilizados para se dirigir ao perfil da "geração perdida": "fração radical de uma geração" (Idem, p.124); intelligentsia militante (Idem, p. 229); intelectual militante (Idem, p. 230); intelligentsia crítica e militante (Idem, p. 230); intelectual divergente (Idem, p. 231); radicalismo intelectual utópico (Idem, p. 233); intelectual crítico (Idem, p. 242). A proliferação de epítetos parece indicar a dificuldade de nomear, oriunda da difícil identidade a ser elaborada.
} 
raízes e não se apoiava sobre um terreno verdadeiramente firme" ${ }^{275}$ E do ângulo da sociedade, "não contava" com "enlace e fortalecimento". ${ }^{276}$ Dessa forma, "esvaziada e enfraquecida de dentro para fora e de fora para dentro", tal geração "tinha de gravitar sobre si mesma, de buscar dentro dos seus muros e de si própria a força para existir, crescer e multiplicar-se", caracterizando-se por sua "segregação espacial, o isolamento cultural global e uma idéia inteiramente abstrata de missão, de relação com a sociedade e de colaboração entre gerações sucessivas". ${ }^{277}$

O duplo estranhamento confere físionomia própria ao grupo. Contudo, não elimina a necessária relação com a sociedade, mediada pela instituição, e com a instituição, mediada pela sociedade. Se o isolamento no interior da instituição e o abandono social estão na gênese do grupo ilhado, para que elaborem e realizem seu projeto, dependem fundamentalmente de uma interação com ambos, embora, deles se segregue para poder se constituir. Florescendo como resposta ao isolamento social e institucional, seria, contudo, da sociedade que buscaria o sentido de seus propósitos e na instituição que encontraria as condições para desenvolvê-los. Paradoxalmente, nos extremos da dupla relação negativa, teve que buscar as fontes de sua própria constituição, e as mesmas fontes de "limitações intransponíveis" foram suas únicas fontes de possibilidades. Assim, declara que o crescimento institucional do grupo dependia de “iniciativas que só podíamos tomar procurando aliados fora e além dos muros acadêmicos não só entre os estudantes, mas nos jornais, entre pessoas ou círculos influentes", transformando-os em "grupo de pressão, que atuava a partir de dentro, mas utilizando meios externos de apoio e de consecução de fins". ${ }^{278}$ De forma que, a auto-afirmação institucional demanda apoio externo, que será tanto mais forte quanto mais o for também o vínculo com a instituição.

Considera o autor, por isso, que os intelectuais poderiam passar da inovação à intervenção efetiva, na medida em que se vinculassem à "irrupção e à violência construtiva dos conflitos de classe". ${ }^{279}$ Contudo, como fazê-lo numa ordem que "restringe o campo histórico" no qual se desenrolam se "intensificam os conflitos de classes"? ${ }^{280}$ Nesse contexto, a intelligentsia, ao sair de sua esfera estritamente institucional não universaliza os parâmetros modernos de sua constituição ideal, mas reproduz a dinâmica da igualdade de privilégios

\footnotetext{
275 “A geração perdida”, p. 219.

${ }^{276}$ Idem.

${ }^{277}$ Idem, p. 220.

${ }^{278}$ Idem, p. 227.

${ }^{279}$ Idem, p. 239.

${ }^{280}$ Idem.
} 
entre os mais iguais, pois seu radicalismo lhe confere prestigio: "ao que levava essa convergência, no fundo tão cômoda, que permitia conciliar, 'espírito crítico' e 'privilégio', as vantagens da posição de classe com as vantagens do radicalismo intelectual" ${ }^{281}$ Trata-se de uma combinação que toma, indesejavelmente, a forma de mais uma das conciliações da ordem autocrática, segundo a qual se reproduz a dinâmica típica de uma sociedade cuja modernidade é restrita. É válido ressaltar a tonalidade sócio-política da análise e o manuseio teórico de orientação weberiana e marxista. $\mathrm{O}$ autor localiza o intelectual dentro da estrutura de classes da sociedade moderna - classe média - e apreende o status a ele associado, típico das tradicionais. E ainda, lança mão de um paralelo histórico entre a condição dos intelectuais universitários e as classes médias que surgiam no final do Império e no início da República, que foram, "bachelarescamente" introduzidas no ambiente da elite - destacando que esse elemento de contestação não ia contra o privilégio enquanto princípio de estratificação social, mas buscava tão somente o acesso a ele.

Essa combinação "não impedia o intelectual crítico de converter-se no porta-voz deste radicalismo, atuando contra a corrente dentro de um extremo puritanismo intelectual”, porém também não permitia ultrapassar os limites de um vínculo fortuito e inorgânico com a sociedade. ${ }^{282}$ Os intelectuais se tornavam mais ligados à ordem que criticavam, através dessa inserção prestigiosa, fomentada por seu radicalismo. A convergência entre radicalismo e prestígio transformava "a base institucional na cidadela de um inconformismo intelectual que não pretendia agredir a sociedade", que "não soltava nem poderia soltar um grito de guerra", emitindo, contudo, "um apelo" aos "que quisessem ouvir a conclamação de uma "nova era das luzes', pela qual o Brasil entraria no reino da civilização industrial e da convivência democrática."283 Florestan Fernandes delineia assim os contornos da segregação, dos intelectuais ilhados falando entre si, idealizando utopicamente a ordem moderna, sem talvez se darem conta de que, a despeito de a projetarem para toda a sociedade, ela era válida, quando muito, apenas para si mesmos, pois limitada à liberdade que lhes fora concedida institucionalmente.

\footnotetext{
${ }^{281}$ Idem, p. 241.

${ }^{282}$ Idem, p. 241.

${ }^{283}$ Idem, p. 241 . Seria bem vindo um estudo que se debruçasse sobre diversas versões para a mesma experiência de formação de um grupo apartado do restante da sociedade e bem circunscrito no interior da instituição. Oliveiros S. Ferreira, por exemplo, pensará a partir da oposição entre comunidade e sociedade, a relação entre o universo acadêmico e a sociedade nacional - não sem lírico saudosismo. A própria obra em que se encontra seu depoimento seria a principal matéria de tal estudo: "Maria Antônia começou na praça". In.: Maria Cecília L. Santos, Maria Antônia: uma rua na contramão, p. 23.
} 
A "proteção institucional" da intelligentsia se torna, em face do desencontro com o meio, a condição de sua existência, como se, ancorada e isolada na instituição, à intelligentsia fosse possível a negação do conservadorismo - e como não lembrar de uma "Plataforma da nova geração", que afirmava a luta precípua contra "todas as formas de pensamento conservador"? ${ }^{284}$ Entretanto, para Florestan Fernandes, essa solução é indício de seu próprio limite, pois a atuação intelectual assim engendrada não atingia o centro da mudança, reformista ou revolucionária. Voltado para o ofício, no interior da dinâmica institucional, o espírito crítico, fonte de privilégio, não apenas foi inócuo para os movimentos de transformação da ordem, mas se tornou instrumental para a manutenção dela, pois, a um só tempo, impediu o vínculo com a sociedade, e não salvaguardou o pensamento do conservantismo, quando este se fez sentir no interior da instituição, cuja autonomia desafiava a abertura democrática da ordem possível nesse capitalismo.

Há um aspecto a ser ressaltado. É evidente que uma das dimensões da memória consiste em construir o passado no presente, através, entre outros recursos, da reconstituição autobiográfica. Se, de acordo com a perspectiva adotada nesse trabalho, seria inadequado pensar a trajetória de Florestan Fernandes em "um antes e um depois", cindidos por 1969, não se pode ignorar que justamente aí se encontre a pedra de toque da narrativa do sociólogo. De alguma maneira, ele se pensa num antes e num depois, crivado pela aposentadoria compulsória, referência que ordena a narrativa. Tendo o traumático desfecho do projeto acadêmico político no horizonte, nele se esmera para vincular e diferenciar passado e presente. $\mathrm{O}$ procedimento pode ser verificado de diversas maneiras, e em várias passagens, mas se evidencia, especialmente, pelo encerramento cronológico dos relatos autobiográficos: tudo se passa como se sua história de vida se esgotasse em 1969, com sua "radicalização", aposentadoria e partida para o Canadá - traço característico, mesmo de entrevistas já no início dos anos oitenta. As experiências posteriores parecem não alçar relevância suficiente para compor o depoimento - ou, talvez, ainda não tenham se tornado passado. Não apenas quando explicitamente "1969" é evocado como divisor de águas, mas na própria concepção da "geração perdida", e de suas relações com a sociedade e a instituição universitária, o episódio é definidor. ${ }^{285}$ Portanto, os cuidados do intérprete devem ser redobrados - as balizas em sua trajetória devem ser matizadas, tanto mais suas elaborações autobiográficas sedimentem a marca da aposentadoria compulsória.

\footnotetext{
284 “A geração perdida", p. 240.

${ }^{285}$ Ver especialmente $A$ natureza sociológica da Sociologia, p. 13; "A geração perdida”, p. 216; A condição de sociólogo, p. 40.
} 
A bagagem de sua formação sociológica é também perceptível nesses relatos. A "coincidência" entre prestígio, isolamento e radicalismo, "que permite compreender o avanço", encontra-se "na origem das impossibilidades"; pois uma "geração intelectual que desabrocha e floresce" sob a proteção do elitismo "fica irremediavelmente condenada a interagir com os conflitos de classes ou pelo pensamento abstrato ou pelas limitadas oportunidades de participação das classes médias nos 'movimentos de opinião' radicalburgueses" - tornando-se "prisioneira de uma instituição que a protege e sob a qual adquire uma base para sobreviver e produzir". ${ }^{286}$ Para ser útil à revolução dentro ou fora da ordem, "seria necessário que o intelectual crítico absorvesse regularmente, em seus papéis culturais institucionalizados e não institucionalizados, o teor reformista e revolucionário dos conflitos de classe"287 - o que considera impossível, pois nem os movimentos sociais e políticos instrumentalizam o conhecimento, nem este, no interior da dinâmica na qual é produzido, pode se vincular aos movimentos. Estes são impedidos de produzir intelectuais próprios ou instrumentalizar os existentes, e a intelligentsia está amarrada a uma dinâmica que inviabiliza qualquer aproveitamento social, senão aquele que mantenha o status quo. O problema da relação entre o intelectual e os movimentos está tanto na fraqueza de um quanto de outro, e vem a ser o mesmo daquela modernidade precária - pois tanto a interação com a sociedade quanto a inserção institucional estão sob o crivo de uma crítica, que as toma no eixo da revolução burguesa, em que, os "dois focos irredutíveis de fraqueza" constituem um único: aquele próprio à ordem social burguesa da periferia, que se reproduz em suas esferas. Por se amalgamarem, sociedade e instituição, nesse único eixo, o que se torna central e distinto da reflexão elaborada no Canadá é que o intelectual não será mais criticado por sua origem de classe, e nem a instituição por seu isolamento, o que será problematizado é o teor de classe do conhecimento produzido pela instituição. É o que faz quando esgarça os vínculos de classe entre a liberdade e autonomia dos intelectuais e a dominação burguesa: a "liberdade de divergência existia e era tolerada porque ele (o intelectual) era parte da elite, não se esperando dele, por conseguinte, que se convertesse em fator de conflito contra a ordem". ${ }^{288}$ Assim, não basta detectar a "contaminação burguesa" ou as "limitações burguesas dos intelectuais". 289 Sua prioridade é destrinchar relações e conflitos de classes que permitam explicar a condição limitada do intelectual nessa modernidade, extraindo daí aspectos sociológicos desse "fracasso" da "geração perdida".

\footnotetext{
286 “A geração perdida”, p. 240.

${ }^{287}$ Idem, p. 242.

${ }^{288}$ A condição de sociólogo, p. 44.

289 "A geração perdida", p. 231.
} 
Dessa maneira, retoma constatação já assinalada: o isolamento, como "situação estrututural", a que o intelectual é programaticamente lançado, para inoculação de sua verve crítica. A liberdade no interior das instituições não se deixa confundir com a autonomia científica propriamente dita. Pois a suposta autonomia não nascia do movimento de constituição interna do meio intelectual em sua diferenciação das demais esferas da vida social, mas de um consentimento externo, cujo fundamento é a aderência a certo grupo social. Nas suas palavras, "a consciência conservadora conferiu ao intelectual uma autonomia que não era intrínseca", porém "extrínseca", que decorre "da posição social, do estilo de vida das classes dominantes e do padrão de dominação conservadora de suas elites" ${ }^{290}$ - padrão este evidente no tipo de instituição idealizada para agasalhar a produção do pensamento. Assim, a liberdade se revela controlada e a autonomia, consentida. A centralidade da Universidade para a formação, encontra sua contra-face negativa na natureza geral das instituições que constituem essa ordem, ou seja: "uma rede institucional de poder, construída, mantida e dinamizada para neutralizar e destruir o pensamento crítico" e qualquer "atuação intelectual militante". ${ }^{291}$ O florescimento de uma intelligentsia nessa rede consiste numa emergência natimorta, fatalidade a que estão sujeitos os elementos modernos no interior dessa revolução burguesa.

A suposição de que a ordem moderna se desenvolvia, alicerce do projeto acadêmico político, e que o empenho por esta direção histórica garantiria o resguardo da morada do saber em sua autonomia compromissada, uma vez colocada em xeque, também descreditaria seus correspondentes contornos institucionais. Os "intelectuais divergentes descobrem" que não "contavam com aquele espaço cultural e que existia uma funda contradição entre os requisitos culturais da ordem social competitiva e o seu funcionamento sob o talão conservador" - sem que os esforços para uma reorientação no sentido de um "alargamento da ordem", abrindo-a às "suas funções e papéis sociais" e "protegendo-os do controle conservador e da pressão reacionária" fosse bem sucedida. ${ }^{292}$ Trata-se indubitavelmente, de uma crítica à própria estratégia de interação com a instituição e a sociedade. Pois se é certo que a "alteração de eixo político”, que passa a ser defendida, desvincula a intelligentsia da dinâmica autocrática da ordem, ela o faz através de uma ruptura com aquela estratégia de centralidade institucional, por conta da necessária ruptura com os vínculos de classe oriundos dela. Para ele, não "foi um erro confiar na democracia ou lutar pela revolução nacional. O erro

\footnotetext{
${ }^{290}$ A condição de sociólogo, p. 45.

291 "Em busca de uma sociologia crítica e militante", p. 141-142.

${ }^{292}$ A condição de sociólogo, p. 48.
} 
foi outro - o de supor que se poderiam atingir esses fins percorrendo a estrada real dos privilégios na companhia dos privilegiados". ${ }^{293}$ Daí, o empenho do autor, tanto em demarcar o que a centralidade institucional significava para a atuação da intelligentsia - a inexorável reprodução da ordem - quanto a busca pela ruptura com dela.

Dispensável, mas importante, sinalizar que o teor da crítica não se presta à defesa da transformação da "cátedra em tribuna", mas pensa na distância em relação a um modelo de modernidade em que a divergência fosse constitutiva da própria ordem. Em que se pesem as condições distintas de produção de um e de outro texto, há sensíveis nuanças com relação à tomada da autonomia como argumento para se opor à intervenção ao regime militar, num raciocínio diverso àquele observado em sua "Autodefesa". Pois a "ética universitária" não é apenas o interdito à transformação do "ensino em fonte de pregação político ideológica"294 inclusive porque, "as opções ideológicas conservadoras, liberais, e radical-liberais" eram veiculadas e submetiam "os estudantes a uma irradiação sistemática de ideologias compatíveis com o controle conservador do poder e com a chamada neutralidade ética", ainda que incompatíveis com o "espírito científico". 295 Então, Universidade "verdadeiramente livre e autônoma" passa a ser aquela em que não há porque se desculpar de posições políticas sob o manto inviolável da "ética" - uma vez que sua autonomia comporta a própria adoção delas. ${ }^{296}$

Encontram-se, ademais, em juízo, pontos nodais do constructo acadêmico. Outrora, a atuação via institucional garantia o vínculo com as causas universais e sustentava a autonomia tendo por fim a modernidade. Contudo, a estratégia institucional se revela atravessada pela "ilusão" daquele tempo, que impedia tomar sua própria "liberdade crítica" na conta de uma liberdade controlada. A crítica à centralidade institucional para a inserção pública atinge o coração de seu projeto acadêmico político: a "tendência a restringir o alcance e o significado histórico dos papéis culturais a compromissos mais ou menos 'profissionais' com a órbita institucional" levou ao equívoco "de que se poderia lutar pela democracia, pelo desenvolvimento e pela igualdade social em um plano, ignorando-se os outros, e a uma subestimação fatal do espírito conservador e reacionário", por isso, o "conflito jamais deveria ser 'contido' na esfera institucional.,297

\footnotetext{
293 “A geração perdida”, p. 245.

294 “Autodefesa”, p. 210.

295 “A geração perdida", p. 229.

${ }^{296}$ Ver: A condição de sociólogo, p. 156-157.

297 “A geração perdida”, p. 243.
} 
Se a aderência aos "valores intrínsecos da ciência" e a atuação a partir da esfera científica institucionalizada eram o pré-requisito e a solução para o problema da intervenção intelectual, agora, a equação respeitosa dos limites das esferas institucionais é tomada em seu ângulo propriamente político. Está em jogo, novamente, a dualidade de referenciais assinalada para a concepção d'A revolução burguesa no Brasil. Se, a seu tempo de formação, a "geração perdida" teve por referencial o próprio meio intelectual universitário e científico; recebe, nos anos setenta, um crivo de avaliação que não se remete exclusivamente ao meio científico, mas procura a significação especificamente política deste meio. Por conta disso, o equacionamento do problema é distinto: um "radicalismo intelectual que se volta para o ofício e só ao acaso opera como um fermento social explosivo não pode ser um fator histórico da transformação reformista ou revolucionária" - pois este acaso é marcado pela fortuidade inelutável de vínculos estabelecidos a partir da instituição que segregam os papéis intelectuais, que restringem a luta política ao plano estritamente cultural e retém o conflito às soluções no interior da ordem. ${ }^{298}$

No interior de uma modernidade realizada por uma contra-revolução burguesa, o moderno está submetido continuamente à absorção de ambigüidades e às oscilações típicas da constituição peculiar da ordem na qual emerge. Não poderia ser diferente, no caso do florescimento do intelectual moderno. Por isso, Florestan Fernandes não titubeia, o intelectual, ao "vacilar diante de uma ordem burguesa impotente", "absorveu as debilidades ou as mistificações que ele condenava." ${ }^{299}$ Paradoxo que sinaliza seu próprio fracasso, pois se absorve as oscilações da realização da modernidade, torna-se vítima da irrealização dos ideais que defende, e "em vez de impor-se como o paladino da atitude política que projetava e encarnava ao nível institucional e na cena histórica, tornou-se a sua principal vítima" ${ }^{300}$ - ou seja, defendendo ideais racionais e modernos, acaba por reproduzir a dinâmica autocrática que preside sua própria perseguição. Desencontro típico do esquema interpretativo da revolução burguesa, "a vanguarda" da modernidade emerge, mas não encontra correspondentes axiomáticos ou institucionais. Assim, a "atitude política inerente à sua posição e às suas orientações intelectuais se esvazia ou se esgota antes ou sem realizar-se, dentro dos limites dos históricos possíveis."301

\footnotetext{
${ }^{298}$ Idem, p. 242.

299 “A geração perdida”, p. 233.

300 Idem.

${ }^{301}$ Idem.
} 
Dessa maneira, em seus projetos de inserção pública e política, o intelectual figura como fiel escudeiro da ordem, tal como ela se apresenta na periferia, autocrática - pois, ao absorver a debilidade da formação moderna, absorve também a força selvagem de manutenção do modelo pelo qual ele se realiza. Por conta disso, o autor procura negar não apenas o limite de "fechamento" da ordem, mas os fundamentos que fazem dessa ordem um espaço perpetuamente fechado. Está em questão uma espécie de insuficiência de grau no questionamento da ordem, que poderia ter levado sua geração a uma diferença substantiva de questionamento da própria ordem. Daí, chegar à “conclusão irretorquível”: a despeito de "todos os seus méritos e realizações positivas, o fragmento de geração intelectual a que pertenço comportou-se, naquilo que seria crucial não imitar os outros e não fazer concessões, como os demais setores da mesma geração. Distinguiu-se destes mais em grau do que em substância", pois "não teve a virtude" de levar sua "lucidez às conclusões práticas necessárias, de repúdio irredutível ao privilegiamento do poder burguês, nacional e estrangeiro, e à ordem estabelecida". ${ }^{302} \mathrm{O}$ esforço na base da crítica é o de buscar uma forma de romper com aquilo que o campo cultural reproduz da dinâmica da própria ordem.

Entretanto, é preciso atentar que a crítica à estratégia centralmente institucional da "geração perdida", é tecida no interior de uma validade fundamental de seu projeto acadêmico político. O descrédito institucional está substancialmente dissociado de um descrédito com relação à ciência. Florestan Fernandes se manterá fiel ao ideal de ciência universalista, estando o sentido de suas críticas intimamente ligado ao tipo de instituição que preside a produção científica no interior de sua interpretação do Brasil. Se a "geração perdida" consiste num "conjunto de intelectuais que enfrentou os seus papéis e, em sentido concreto, cumpriu suas tarefas. Mas, nem por isso, chegou a atingir os seus objetivos e a ver o seu talento aproveitado pela sociedade" ${ }^{303}$ - esse desencontro seria o fundamento da validade de seus propósitos, signo do dilema entre o moderno que a ordem não comporta e a necessária ruptura com a ordem para a realização dessa mesma modernidade. Dramaticamente, essa validade se expressa numa indagação indignada: "que deve fazer o fragmento radical de uma geração quando descobre que perdeu sua oportunidade porque teve fé na razão e confiança no homem? Diante da obra esboroada, os agentes devem ruir com os andaimes ou cumpre indagar por que as 'tarefas perdidas' não são 'tarefas condenadas'?”, 304

\footnotetext{
302 “A geração perdida”, p. 244.

303 Idem, p. 213.

${ }^{304}$ Idem, p. 245.
} 
O objetivo central, "uma diferenciação estrutural", na qual "o intelectual tivesse o grau de liberdade efetiva para desempenhar os papéis inerentes à sua atividade" tinha fundamentação “intelectual, não nascia de um movimento político. ${ }^{305}$ Entretanto, ao colocarem "à prova o seu papel de intelectual" e enfrentarem "aquele papel dentro de exigências máximas" e com uma "intransigência específica, inerente à responsabilidade”, “o intelectual como cientista, o intelectual como professor, e por aí a fora"306, a moderna adesão da intervenção à esfera da competência tomava proporções políticas imprevistas, pois em sua modalidade autocrática, qualquer empenho por autonomia e liberdade intelectuais adquire sentido político - que, aliás é empregado numa concepção alargada em relação àquela que presidia a constituição da "geração perdida", quando "político" era mormente associado àqueles que "exerciam diretamente o comando das decisões ou detinham alguma parcela do poder político estatal". ${ }^{307}$ Possivelmente, a ampliação de sentido não se deva apenas ao exercício de reflexão sobre o passado. Também o contexto autoritário concorre para tanto, pois amplia o espectro de atitudes consideradas "políticas", contemplando desde a assinatura de um abaixo-assinado até a presença em uma missa ecumênica. ${ }^{308}$

A "perda" da "fração de geração" se dá, portanto, por conta do desencontro entre a "modernidade" do procedimento e a "modernidade" do meio social. O "equívoco" não estava em seus propósitos, fadados a não encontrarem no meio social o revérbero e a interação necessários para que vingassem. Na verdade, “os conflitos destrutivos não teriam surgido se a sociedade brasileira fosse efetivamente uma sociedade democrática" ${ }^{309}$, pois se assim fosse, os conflitos seriam absorvidos, e a ordem se flexibilizaria e se fortaleceria ao absorvê-los.

Por isso, no cerne da impossibilidade de sua realização, encontra-se também a validade dos ideais por que lutou. Esse desencontro entre projeto e a possibilidade de realização histórica, força bifronte que move a reflexão está no cerne de nova ambivalência à qual se vê lançado seu projeto acadêmico político. ${ }^{310}$ Vimos que no Canadá, sua validade era proeminente ao estabelecer os contornos formais de uma proposta de prática científica de resistência. Mas aqui, são justamente os impeditivos para sua realização que dão testemunho

\footnotetext{
${ }^{305}$ A condição de sociólogo, p. 56.

${ }^{306}$ Idem, p. 57.

307 “A geração perdida”, p. 218.

${ }^{308}$ Maria Hermínia Tavares de Almeida e Luiz Weiz, "Carro-zero e pau-de-arara”, p. 338.

${ }^{309}$ A condição de sociólogo, p. 56.

${ }^{310} \mathrm{Na}$ costumeira força expressiva do autor - que justapõe termos coloquiais, dando sentido preciso a suas idéias, como "circuito fechado" - esse desencontro entre a modernidade da intenção e as condições gerais que convertem o resultado em seu avesso, é denominado como uma "breve história da sociologia no Brasil", "uma extravagante curiosidade". "A Sociologia como contestação”. In.: A Sociologia no Brasil, p. 128.
} 
da validade do projeto. Daí afirmar, uma "geração perdida não é uma geração derrotada e, muito menos, inútil". 311

Permanecendo em seu horizonte a "utopia da racionalização da convivência humana" ${ }^{, 312}$, uma nova ambivalência se coloca para seu projeto acadêmico político, cuja realização se vincula então à constituição de outra ordem social. Por isso, embora suas expectativas e "palavras sejam as mesmas"; como as "realidades históricas emergentes são e devem ser diametralmente opostas"; para que a intelligentsia defenda a liberdade, a nação e a democracia - é necessário que rompa com seu "aprisionamento pelas malhas conservadoras da ordem existente". ${ }^{313}$ Tudo se passa como se a coincidência que existia entre os ideais da modernidade, a Nação e o intelectual moderno, agora fossem estabelecida entre esses termos no interior de uma ordem socialista. Está seguro o autor de que a periferia do capitalismo, não pode "restaurar o passado morto das nações hegemônicas" ${ }^{314}$, não sendo possível propor, portanto "as idéias de Nação e Democracia ao estilo da Europa e dos Estados Unidos do século XIX". "Ilusão" parece definir para o autor suas formulações anteriores. Afirma que, na verdade, "a democracia e a revolução nacional só podem existir como mitos, não como realidades históricas", o que exige "uma resposta, fora e acima das velhas ilusões e das antigas acomodações". ${ }^{315}$ Em prefácio à segunda edição d'A Sociologia numa era de revolução social, em 1976, tais convicções dão o tom com que se apresenta a aposta pretérita. Para ele, tratam-se de "ensaios se abriam para um presente histórico que entrou em crise. Essa crise, porém, atingiu a revolução democrática e a viabilidade dos objetivos" neles traçados. ${ }^{316}$ Portanto, o "que era no começo", apenas, "índice de "vocação socialista', agora se impõe como a única saída possível”, o intelectual deve se empenhar "no fortalecimento e na difusão do movimento socialista, ou ele voltará a ser um joguete nas mãos das forças culturais de conservação da ordem"317, pois o "impasse atual é claro": “capitalismo dependente (...) ou

\footnotetext{
311 “A geração perdida”, p. 214-215.

312 Sylvia Gemignani Garcia, Destino impar, p. 173.

313 “A geração perdida", p. 247.

314 Idem.

315 Idem, p. 246

316 A Sociologia numa era de revolução social, p. 10-11. Para uma comparação entre os prefácios de 1962 e 1976, com nuanças em relação ao que aqui apresento, ver: Élide Rugai Bastos, "Florestan Fernandes e a construção das ciências sociais". In.: Paulo. H. Martinez, Florestan ou o sentido das coisas.

317 “A geração perdida", p. 252.
} 
'revolução contra a ordem' pela via socialista." 318 E como não se lembrar diante dessa pergunta, de Fernando Henrique Cardoso, e seu "subcapitalismo ou socialismo"? 319

Se o projeto foi defendido em função de expectativas não realizadas historicamente, pensar aqueles "objetivos" passa a ser uma problemática do que deve ser a autonomia científica, a modernidade e a democracia, na ordem socialista. Daí, a compreensão de que "não há como conciliar a sociedade capitalista com semelhantes funções da ciência e do planejamento democrático", pois "o capitalismo cria conflitos insanáveis entre a intervenção racional, baseada na ciência, e os propósitos intrínsecos aos meios privados de dominação e de organização do poder estatal." ${ }^{320}$ Como bem assinala Sylvia Gemignani Garcia, o desencanto, na raiz das críticas, não coloca em questão "a potencialidade do pensamento cientifico enquanto tal, em função de suas próprias características" - seu ponto central é o exame das "possibilidades de constituição e desenvolvimento em uma certa ordem sociohistórica. A idéia do que a ciência deve e pode ser não é o foco do questionamento, por outro lado, uma reviravolta atinge a análise das condições sociais necessárias à implantação efetiva desse tipo de conhecimento." ${ }^{321}$ A reviravolta, evidentemente, reverbera a virada ocorrida na própria concepção de modernidade possível na periferia do capitalismo, cuja viabilidade é condicionada a uma sociedade socialista.

Essas nuanças o conduzem, inclusive, a crescente associação entre as concepções em torno da "Sociologia Aplicada" e as demandas e possibilidades cogitadas para uma sociedade socialista. $\mathrm{O}$ autor considera que naquele constructo pensava antes nos "requisitos ideais da ciência e da intervenção racional do que com as limitações práticas de uma sociedade capitalista dependente. Em uma sociedade planificada e uma sociedade planificada em escala nacional deve ser necessariamente socialista - é provável que a ciência adquira as funções que eu presumia." Ao que parece, há um reconhecimento melancólico de que em suas formulações pressupunha aquilo que pretendia instaurar, relações sociais tendentes à secularização e racionalização - pois confessa: "constato que, se por um lado explorei possibilidades de grande significação, de outro lado superestimei as condições do ambiente para a pesquisa sociológica aplicada". ${ }^{322}$

\footnotetext{
${ }^{318}$ A Sociologia no Brasil, p.124.

${ }^{319}$ Fernando Henrique Cardoso. Empresário industrial e desenvolvimento econômico no Brasil. São Paulo: Difel, 1972, $2^{\mathrm{a}}$ ed.

${ }^{320}$ A condição de sociólogo, p. 132.

${ }^{321}$ Destino ímpar, p. 164.

${ }^{322}$ A condição de sociólogo, p. 83.
} 
Ora, ter as limitações da realização da modernidade em vista implica em reconfigurar as possibilidades e os parâmetros de realização de seu próprio projeto de intervenção intelectual - pois o enquadramento interpretativo da experiência intelectual pretérita expõe a insuficiência de sua formulação para o problema da inserção política do intelectual. Trata-se indubitavelmente de um exercício de extração dos conseguintes políticos, no âmbito intelectual, das conclusões a que chegou em A revolução burguesa no Brasil, em congruência com a validade fundamental da ciência que, em seu sentido iluminista e universalista, passa a encontrar condições sociais de realização, somente numa ordem social planificada.

Entretanto, se a "adesão de Florestan Fernandes à ciência caminha pari passu com a forte ligação à universidade",323, as críticas em relação às condições sociais que conferem à instituição um caráter cerceador à autonomia científica teria desdobramentos, não apenas em nível analítico, como fica patente, mas em âmbito programático - acerca do que deva encetar, como atividade, a intelligentsia. Um aspecto central do constructo dizia respeito à aderência da intervenção à esfera da competência, tendo por eixo ideal o estabelecimento de uma relação com a sociedade mediada pela instituição da ciência. Como uma nova proposta seria equacionada diante das novas conclusões, se nelas a ruptura com a ordem é pré-condição para a racionalização da vida social, e, concomitantemente, a ruptura com a instituição se torna pré-condição para autonomia? Esse problema persiste nos escritos do autor.

Lançar mão de nossas "peculiaridades" com relação a "casos clássicos" é lugar comum na bibliografia. Contudo, a trajetória de Florestan Fernandes parece encontrar algum abrigo nesse esquema. Não será tributária dessa peculiaridade, a singular circunstância de que um mesmo sujeito seja arauto paradigmático da modernidade e da ciência no Brasil, e também o crítico radical das mesmas? Maria Arminda do Nascimento Arruda, seguindo apontamento de Fernando Novais, sugere que se a emergência da Sociologia, nos países centrais, vincula-se a uma modernidade efetivamente realizada; no Brasil, ela é fruto de uma modernidade bloqueada. Por conta disso, os traços de sua irrealização favorecem o surgimento de posturas sociológicas críticas já com relação à própria modernidade que a origina - o que seria condicionante inclusive da absorção do marxismo na Sociologia paulista, evidente no famoso "Seminário de Marx". ${ }^{324}$ Nessa chave, também pode ser interessante pensar a absorção de Max Weber, posto que sua obra é apropriada para compreender não as

\footnotetext{
${ }^{323}$ Metrópole e cultura, p. 326.

${ }^{324}$ Idem, p. 300.
} 
"patologias da modernidade", mas as "patologias de acesso à modernidade". ${ }^{325}$ Por esse viés, talvez não seja demasiado inferir que nossa particularidade, manifesta na emergência de uma Sociologia crítica em relação à modernidade de que é originária, resulte também numa sociologia autocrítica, que evidencia o padecer de limitações insanáveis compartilhadas com o contexto de que é oriunda - vertente que encontraria em Florestan Fernandes representante exemplar. ${ }^{326}$

Não se pode passar insensivelmente a dois aspectos especialmente delicados desses relatos. Em primeiro lugar, a proximidade entre o trato de biografias já desenvolvido no início de sua carreira e o que empreende nesses textos - é certo que, com "extrema sensibilidade humana e sociológica, Florestan faz a própria história de vida." ${ }^{327}$ E, se em suas análises sociológicas das histórias de vida, "toma o desencontro do homem com sua obra" como "seu objeto central de estudo" ${ }^{\text {328 }}$, também em sua reconstituição autobiográfica, os desencontros são o conflito motor de sua narrativa. Demos, pela pertinência à problemática tratada, destaque àqueles que se referiam ao descompasso entre seu projeto acadêmico político e as condições históricas de sua (não) realização. Contudo, é certo que ele se relaciona, tanto com a busca pela descoberta das "alternativas que a sociedade abre para seus membros (e também as alternativas que fecha)"; quanto com a afeição "pelas biografias que 'contrariam' a História, como é o caso da sua própria". ${ }^{329}$ Não terá sido a utopia de que contrariar a História pudesse se tornar lei sociológica - podendo então aqueles que deixou "para trás" em seu percurso de ascensão social, para os quais sua história é exceção e não regra, também contrariarem sua destinação - um dos fundamentos de sua "profunda identificação com os ideais de civilização moderna"? ${ }^{330}$ Com efeito, ao estudo da "história de vida dos que se insurgem contra o destino traçado" e da configuração de uma ordem social que abra tal possibilidade, Florestan Fernandes dedicou seu poderoso instrumental sociológico.

Em segundo lugar, vale ressaltar o sentido que Sylvia Gemignani Garcia atribui às oscilações de perspectivas que figura nos depoimentos analisados. Para a autora, é possível identificar uma "versão realista", caracterizada por "diagnósticos cortantes dos fatores sociais

\footnotetext{
${ }^{325}$ Luiz Werneck Vianna. "Weber e a Interpretação do Brasil”. In.: Novos Estudos CEBRAP, n. 53. São Paulo: março 1999.

${ }^{326}$ E na comemoração dos cinqüenta anos da USP, especial saliência. Ver: A Questão da USP.

${ }^{327}$ Sylvia Gemignani Garcia, Destino impar, p. 17.

328 José de Souza Martins, "Vida e história na sociologia de Florestan Fernandes". Revista USP, n. 29. São Paulo, março/maio, 1996, p. 19.

${ }^{329}$ Idem, p. 15.

${ }^{330}$ Maria Arminda do Nascimento Arruda e Sylvia Gemignani Garcia, Florestan Fernandes, mestre da sociologia moderna. Brasília: Paralelo 15/Capes, 2003, p. 23.
} 
condicionantes da própria posição intelectual e trajetória institucional”; e uma mais compreensiva com relação aos " ideais, valores e diretrizes que davam sentido geral àquelas posições" - sendo, ambas, "dimensões do mesmo fenômeno",331. Dentro da análise aqui esboçada, é possível entender que essas duas versões se colocam como dois olhares sobre o passado: a versão idealista apreende o passado por suas intenções coevas, ao passo que a versão realista apreende o passado no interior de seu esquema interpretativo presente - daí o "diagnóstico cortante", e contraditório, pois anacrônico - na medida em que o passado e o projeto acadêmico são avaliados segundo elaborações que não existiam quando foram projetados. ${ }^{332}$ Com efeito, os laços entre intelligentsia e revolução burguesa, tal como se colocam então, não eram concebidos no momento em que eram vividos, pois se o fossem, o projeto acadêmico político não teria sido pensado sobre as bases em que o foi.

Evidentemente, o conhecimento do desfecho da história afasta os homens de seu próprio passado, na medida em que, como sujeitos dessa dimensão temporal quando ela era presente, desconheciam os rumos que tomariam os eventos - que, uma vez conhecidos parecem dotados de racionalidade intrínseca. Se essa condição é inexorável, o "perigo do anacronismo" é, contudo, "mais violento na autobiografia", por ser "muito difícil você contar sua vida sem ser anacrônico. A tentação é contar a vida que você queria que tivesse tido", conforme Fernando Novais, afirma a propósito do próprio Florestan Fernandes. ${ }^{333}$

A coloquialidade desse entendimento entre historiadores de proa não elimina do horizonte, contudo, a sofreguidão ímpar que se extrai de um sujeito elaborando seu passado, oscilando entre uma autocrítica anacrônica e um lamento compreensivo. Aliás, quando é tecida uma crítica aos aspectos da cultura política dos quais pretende se dissociar no presente, ainda que tenha deles compartilhado no passado, essa ambigüidade se manifesta com contundência. A reconstituição autobiográfica elabora um "outro" do "mesmo", na medida em que forja uma fisionomia política, que consiste numa ruptura consigo próprio. Deslocando o referencial especificamente cientifico na origem dos posicionamentos pretéritos, para a apreensão de seu significado especificamente político, que passa a interessálo no presente, considera suas relações com a política nos anos cinqüenta e sessenta. Em

\footnotetext{
${ }^{331}$ Destino impar, p. 165-171.

332 É o que se observa na incongruência dessas passagens: "por mais que se contenha a severidade da análise, a correlação entre geração, classe e atividade intelectual gerou contradições que a intelligentsia crítica não tentou equacionar e resolver". (“A geração perdida”, p. 243). Como sustentar então que o "dado paradoxal dessa situação nunca deixou de (...) atormentar e (...) vinha constantemente à tona e à (...) consciência."? (Idem, p.217).

${ }^{333}$ Aproximações, p. 398-399.
} 
insistentes acusações, dirigidas aos equívocos da esquerda, com os quais não "compartilhou", ganha relevância sua adesão à "revolução contra a ordem"334, apresentada, paradoxalmente, junto à lamentações por ter aderido a esses mesmos pontos, destacando-se sua adesão à "revolução dentro da ordem". ${ }^{335}$ Ora, quando perguntamos, como Alfredo Bosi, "o que fazia a inteligência universitária de São Paulo", posto que ela não adere ao "projeto nacionalpopulista" e é ciosa de sua "distância em relação ao trabalhismo" ${ }^{336}$, reconhecemos, a despeito disso, traços da cultura política dos anos 1950-1964 que se fazem presentes na Universidade. Pois, "seu desenvolvimentismo vai ater-se ao plano educacional; as suas bandeiras serão o aperfeiçoamento do ensino superior" e a "defesa da escola pública." ${ }^{337}$ Assim, o projeto de modernidade do sociólogo o distingue fundamentalmente do espectro da cultura política "nacional-popular" - que abrange do nacional desenvolvimentismo isebiano ao etapismo comunista. ${ }^{338}$ Contudo, sua ambição de emparelhar o país com os países de modernidade originária o ligava às esperanças de futuro frustradas em 1964. E é evidente que o elo entre a produção do sociólogo e algumas expectativas sociais referia-se às condições de realização do projeto de modernidade, naquele momento tomado como possível nos quadros de uma ordem capitalista.

Destacando os sentidos, para o presente, das críticas à experiência pretérita, a relação entre a elaboração da memória e a constituição da identidade não pode ser oculta. A configuração da personalidade intelectual através da retomada do passado vem acompanhada das vicissitudes de apreensão do tempo pretérito, razão pela qual Florestan Fernandes oscila, incessantemente, entre a autoconsciência anacrônica e a confissão melancólica. Com efeito, o traço melancólico é oriundo das condições presentes. $\mathrm{O}$ entusiasmo quanto às possibilidades de superação do passado e a expectativa de um futuro promissor são vibrantes nos textos daquele período ${ }^{339}$ - tomados, nos setenta, como "ilusórios". A mais superficial consideração de sua atuação pública, nos anos cinqüenta e sessenta, não corrobora afirmações como:

\footnotetext{
${ }^{334}$ Ver longo trecho d'A condição de sociólogo, p. 155; e "A geração perdida", p. 244-245

${ }^{335}$ Confessa cabalmente na apresentação do percurso, de "perda de ilusões" e superação de "hesitações" que o leva às conclusões d'A revolução burguesa no Brasil, encontrada em "Em busca de uma sociologia crítica e militante", p. 199-202; e nas comparações que faz entre A Sociologia numa era de revolução social e suas expectativas após o mencionado percurso, em "Democracia e desenvolvimento". In. A Sociologia no Brasil, p. 256

${ }^{336}$ Alfredo Bosi. "Um testemunho do presente". In.: Carlos Guilherme Mota. Ideologia da cultura brasileira (1933-1974). Pontos de partida para uma revisão histórica. São Paulo, Ática, 1977, p. V.

${ }^{337}$ Idem.

${ }^{338}$ Bibliografia usual trabalha nessa direção, contrapondo a vida intelectual paulista e a carioca, por exemplo Maria Hermínia Almeida. "Dilemas da institucionalização das Ciências Sociais no Rio de Janeiro"; e Sérgio Miceli. "Condicionantes do desenvolvimento das Ciências Sociais" - ambos In.: Sérgio Miceli (org.). História das Ciências Sociais no Brasil, v. 1. São Paulo: Sumaré, 2001.

${ }^{339}$ Idem, p. 17.
} 
"minha contribuição sociológica se definia no plano mais baixo possível" e "minhas veleidades socialistas eram pura e simplesmente sufocadas". ${ }^{340}$ Entretanto, o fechamento das vias de atuação e as difíceis condições de militância nos anos da ditadura, impõem definições no "plano mais baixo possível" - circunstância que a um só tempo demanda e impede ultrapassar o obstáculo entre o diagnóstico dos "equívocos" passados e torná-lo fundamento de uma nova proposta de intervenção política.

Seriam inúmeras as passagens que dão testemunho dessas ambigüidades. ${ }^{341}$ Não convém arrolá-las excessivamente. É imperioso, contudo, assinalar: especialmente no que diz respeito à adesão à revolução "dentro da" ou "contra a" ordem, o autor se veria em face das vicissitudes típicas que a história in flux coloca àqueles que aderem ao socialismo. $\mathrm{O}$ enfrentamento dessa problemática, numa conjuntura política instável, marcada por possibilidades múltiplas de rumo histórico - entre os fluxos e refluxos da distensão e a emergência dos de abajo tão característica de fins de setenta e início dos oitenta - se processa numa teia complexa de fatores que conduzem o intelectual à redefinição de sua identidade.

Nesses depoimentos, as limitações do passado atravessam toda a reflexão, focada nos impedimentos do capitalismo à autonomia intelectual. Talvez por isso, socialismo e racionalidade científica sejam continuamente associados a partir de então, e ciência e revolução, como outrora modernidade e ciência, teçam relações profícuas nos textos dedicados à temática da identidade intelectual. Contudo, para que esse caminho fosse trilhado, seria necessário que o autor transitasse do foco das "limitações do capitalismo", para a elaboração de uma proposta de intelectual e de trabalho científico negadora da ordem capitalista periférica, especificamente socialista, e forjada no interior dessa mesma ordem, ainda vigente. $\mathrm{O}$ autor permanece, contudo, ao cabo de seus intentos através dessas memórias, amarrado às cordas de uma bifurcação sem saída - na qual o componente melancólico dá o tom. No retorno ao passado, a busca pelo sentido do presente quer desafiar as condições de dubiedade quanto aos rumos futuros - sempre com o objetivo de encontrar a subjetividade histórica do intelectual. Porém, ainda que pretenda "ir ao fundo do poço e sair dele não com a amargura da frustração e do derrotismo, mas com uma explicação que repõe as coisas em seus devidos lugares"342, ainda que reafirme "as lições do passado esclarecem o presente,

\footnotetext{
${ }^{340}$ A condição de sociólogo, p. 155.

${ }^{341}$ Entre as quais, não se pode deixar de assinalar o esforço pelo do epíteto de "marxista", também notado por Fernando Novais (Aproximações, p. 398). Aspecto que em nosso perscrutínio ficou evidente, tanto através de sua autodefesa com relação à não utilização teórica de Marx, quanto na reivindicação pelo parentesco teórico ideológico com o marxismo. Ver $A$ condição de sociólogo, p. 83-91.

342 "A geração perdida”, p. 214-215.
} 
ensinando o que se deve fazer para que o pensamento conservador e a contra-revolução sejam derrotados"343 - não escapa à desconcertante condição de tentar fugir de uma sina e desembocar precisamente nela. O esclarecimento não responde "o que fazer" - permanecendo suspenso - é "algo que devemos descobrir"344, conforme afirma no final de suas linhas.

O deslocamento sugerido requer que autonomia científica, democracia e modernidade não apenas sejam tomadas como possivveis em outra ordem, planificada e socialista - mas tenham precisamente delimitado o seu significado numa ordem na qual não são viáveis; e exige que sejam equacionadas no processo de revolução in flux, que leva à sociedade na qual cumprem sua promessa de emancipação humana. A história conduziria a reflexão a esse rumo - tema da próxima fase, em que o intelectual, cuja crise de referenciais leva a uma perda irrecuperável da aposta na instituição, efetivamente se reconstitui.

\footnotetext{
343 Idem, p. 245.
}

${ }^{344}$ Idem, p. 251. 


\section{Militância solitária e "nova esquerda".}

É indubitável que qualquer reflexão sobre o próprio métier tem por interlocutores precípuos os próprios pares. Essa circunstância já tornaria imperioso um breve olhar sobre o "núcleo estratégico" da "geração perdida", ao qual dedica A revolução burguesa no Brasil, bem como o destino presente da "aventura comum", em que consistiu o esforço, com ele partilhado, em "vincular a investigação sociológica à transformação da sociedade brasileira". ${ }^{345}$ Nesse diálogo se encontra a razão de ser da crítica do autor, confessa em intenção assumida: “já é tempo de se salientar, através de um de nós, o que tínhamos em comum - não o típico dos extremos, mas o típico do que era compartilhado, com maior ou menor intensidade". ${ }^{346}$ Tempo que repõe outros tempos, como é típico dos momentos de recordação, liga esta a outra intenção - menos "prestar um depoimento" que "travar um combate",347 - que retoma o "ato de construção intelectual", como "um ato político",348 - ardil de que se valeu em sua "Autodefesa".

Intelectuais historicamente ligados a esse núcleo estão no centro de dois fenômenos sem precedentes na história brasileira, localizados de meados a final dos anos setenta: o movimento de intelectuais em massa para a esfera política, e o debate mobilizado em torno do tema da democracia. Tratam-se de dois fenômenos em íntima correlação, cuja compreensão requer a consideração da militância profissional e intelectual, das instituições que lhe dão suporte, e das vicissitudes da conjuntura política. ${ }^{349} \mathrm{Na}$ imbricação desses aspectos também se delimita o terreno no qual germinam, solitariamente, as posições de Florestan Fernandes.

A imagem do "militante solitário" é sugerida por Antonio Candido na primeira grande homenagem coletiva prestada a Florestan Fernandes no campus da Unesp de Marília, e fica consagrada ao intitular o trabalho de Eliane Veras Soares. ${ }^{350}$ Qualificação que não deve ser confundida com um isolamento quixotesco e radical - imagem forjada, contudo, por declarações do próprio Florestan Fernandes, como aquela na qual se explica, acerca do aceite

\footnotetext{
345 "Núcleo estratégico" denomina o seguinte grupo: Fernando Henrique Cardoso, Octávio Ianni, Luiz Pereira, Maria Sylvia de Carvalho Franco, Leôncio Martins Rodrigues Netto, José de Souza Martins, Gabriel Cohn, José Cesar A. Gnaccarini, José Carlos Pereira. (A condição de sociólogo, p. 24; e dedicatória d'A revolução burguesa no Brasil.)

346 “A geração perdida", p. 216-217.

${ }^{347}$ Idem, p. 214.

348 Tomo emprestada a formulação de Antonio Candido em 1987. “Amizade com Florestan”. In. Maria A. D'Incao (org.). O saber militante, p. 34.

${ }^{349}$ Daniel Pécaut, Os intelectuais e a politica no Brasil, p. 192.

350 “Amizade com Florestan”, p. 35; Florestan Fernandes: o militante solitário, respectivamente.
} 
ao convite para colaborar periodicamente na Folha de S. Paulo: foi necessário que superasse o sectarismo do "guerrilheiro político isolado". 351

Compreender tal isolamento é delinear os contornos de sua inserção particular no meio intelectual e político: sem contrapô-lo, e perder a dimensão de sua pertinência; nem inseri-lo superficialmente, e ignorar suas posições próprias. Para tanto, as reflexões a que se dedica esse trabalho são lapidares, pois em suas críticas referentes aos contornos da identidade política intelectual, especialmente relacionadas à imbricação entre profissão e democracia na militância de seus pares, fica saliente a solidão e a pertinência ao meio. Por isso, a presente seção quer estabelecer os termos de sua inserção solitária no interior do espectro político cultural oposicionista, que fica conhecido como "nova esquerda".

As origens da "nova esquerda" na tradição política são conhecidas. No ano de 1956 seria detonado o mais expressivo movimento de crítica interna da esquerda identificada com o marxismo e a revolução - o XX Congresso do PCUS, as revoltas na Hungria e na Polônia, que expunham de forma dramática as veleidades do stalinismo, concorrem para desencadear o auto-questionamento numa velha esquerda, marcada pela centralidade de seus partidos comunistas, pretensos fiadores da correta interpretação da história. A novidade na "nova esquerda" daí oriunda está em ser "menos dogmática em sua perspectiva e menos exclusivamente política em seu compromisso". 352

Evidentemente, não se pode dizer, desde pelo menos a vitória da revolução cubana, que os meios culturais à esquerda no Brasil, tivessem predileção pela referência soviética. ${ }^{353}$ Contudo, o oposicionismo que ganha expressão social e política sob o epíteto de "nova esquerda”, guarda afinidades com a agenda e perspectiva política daquela vertente, em seu humanismo, igualitarismo, em seu interesse por problemas como educação, vida cultural e pelas "relações sociais nas questões do dia-a-dia da vizinhança e do local de trabalho"354 mesclando aí, a oposição à sua "velha esquerda" e à sua direita.

Essa mescla é possível pela identificação, em ambas, do autoritarismo, tema central da nossa "nova esquerda". É compreensível que "democracia e autoritarismo", mais que

\footnotetext{
${ }^{351}$ Que tipo de República? São Paulo: Brasiliense, 1986, p. 13.

352 Tom Bottomore. Críticos da sociedade. Rio de Janeiro: Zahar, 1970, p. 68-69.

${ }^{353}$ Carlos Alberto Barão. "A influência da revolução cubana sobre a esquerda brasileira nos anos 60". João Quartim de Moraes e Daniel Araão Reis Filho (orgs.). História do marxismo no Brasil. O impacto das revoluções, v.I. Campinas: Unicamp, 2003.

${ }^{354}$ Tom Bottomore. Críticos da sociedade, p. 68-69.
} 
"capitalismo e socialismo", polarizem o debate, pois esse se constitui numa dupla oposição: à sua antecedente política derrotada e ao regime autoritário que a derrotou. Se à direita, ele se presentifica no regime a ser enfrentado, é também identificado no interior da própria esquerda, sendo associado, em alguma medida, às traumáticas derrotas - de 1964, e da década de setenta, com a dizimação dos ensaios de luta armada. A "nova esquerda", ao estabelecer com a tradição política nacional um profícuo diálogo crítico, esgarça seus melindres. Não por acaso, um trabalho como ISEB: fábrica de ideologias, de Caio Navarro de Toledo é contemporâneo a 1930. O silêncio dos vencidos, de Edgar de Decca, ao mesmo tempo em que A revolução de 1930 é revista por Boris Fausto e a histórica crítica uspiana ao populismo tem em Francisco Weffort um de seus arautos. Do pensamento político da Primeira República e suas relações com a "Revolução de 30" à cultura política "nacional-popular", "nacionaldesenvolvimentista" - o teor autoritário que figurou em diversos momentos históricos não terá passado incólume ao crivo da "nova esquerda".

Expoentes dessa perspectiva estão historicamente ligados à crítica da cultura política do nacional-popular, elaborada em âmbito acadêmico, nos anos sessenta, sob a batuta de Florestan Fernandes. Seus desdobramentos ganham agora sentido especificamente político e permitem, simultaneamente, apreender os termos básicos do debate acerca da democracia nos anos da distensão do regime militar e algo de sua herança uspiana. A ambigüidade dos parâmetros anteriormente assinalada - o intelectual e o especificamente político - está em jogo não apenas nos posicionamentos de Florestan Fernandes, porém são decisivos na delimitação do debate travado na "nova esquerda". A retomada, em novos tempos, de um debate sociológico de décadas anteriores, é índice da inserção de Florestan Fernandes nos dilemas enfrentados pelos protagonistas da "nova esquerda" - sendo a mais bem acabada expressão de sua participação nesse debate, a concepção de revolução burguesa na periferia que elabora. Nem tudo identifica, entretanto, Florestan Fernandes à "nova esquerda". Há distinções a se acenar, elas estão na base de sua inserção solitária.

Considerar o prestigiado núcleo intelectual, protagonista do enquadramento dos anos setenta que nos concerne, esboçando as imbricações entre a militância profissional e intelectual, suas instituições e a conjuntura política, implica em considerar as transformações por que passaram o meio cultural durante os anos do regime militar. Já há algum consenso na bibliografia, acerca do tipo de censura promovida pelos militares não incidir sobre as artes e a cultura, mas sobre obras específicas, havendo mesmo um inegável fomento financeiro do regime às áreas culturais. Segundo Renato Ortiz, a década de setenta "conhece uma 
formidável expansão do mercado de bens simbólicos; cinema, televisão discos”, crescimento que "traduz a reorganização do panorama cultural numa sociedade na qual o capitalismo avançado se consolida. ${ }^{355}$

No que se refere ao campo científico, graças à "modernização, expansão e centralização de recursos pelo governo militar" assiste-se a um crescimento sem precedentes das Ciências Sociais, pelo qual se forma uma elite intelectual profissionalizada. ${ }^{356}$ De forma que, o "número de sociólogos também se multiplica, novas carreiras são abertas junto às fundações de pesquisa, às Secretarias de Estado, às empresas privadas (indústria cultural, publicidade)." 357 A profissionalização em massa e a especialização acelerada são decorrências patentes das transformações que ocorrem "no contexto de um regime autoritário cujas políticas educacionais favoreceram a expansão do ensino superior enquanto espaço prioritário de atendimento às reivindicações de melhoria formuladas pelos setores médios que viviam se batendo, desde fins dos anos 50, com a questão dos chamados excedentes", segundo Sérgio Miceli. ${ }^{358}$

Renato Ortiz ressalta o paralelismo entre a modernização da sociedade e o desenvolvimento das Ciências Sociais, tributando o tipo de profissionalização à forma política autoritária que fomenta sua expansão. ${ }^{359}$ A singular circunstância desse fomento ser ativado por um regime ditatorial fez com que "o braço repressor, ao lado da racionalização da sociedade" acelerasse o "hiato geracional, legitimando uma nova prática científica" e a "produção em Ciências Sociais" se tornasse "simples reprodutora da razão organizacional". 360 O reconhecimento em jogo nos esforços pela regulamentação da profissão, por exemplo, é por um profissional "que realiza pesquisas e interpreta dados sócio-econômicos e culturais"; em oposição à "forma 'tradicional' de se pensar a Sociologia como saber universal e crítico."361 Questionando a espécie de Sociologia que passa a ser produzida nesse contexto, a conclusão do autor é que, comprometida ou não com questões sociais, envolta em intenções humanistas

\footnotetext{
${ }^{355}$ Renato Ortiz, "Notas sobre as ciências sociais no Brasil", p. 169-170.

${ }^{356}$ Bernardo Sorj. "Estratégias, crises e desafios das ciências sociais". In.: Sérgio Miceli (org.). História das Ciências Sociais no Brasil, v.2. São Paulo: Sumaré, 1995, p. 323.

${ }^{357}$ Renato Ortiz, "Notas sobre as ciências sociais no Brasil", p. 170.

${ }^{358}$ Sérgio Miceli. "O cenário institucional das ciências sociais no Brasil". In.: Sérgio Miceli (org.). História das Ciências Sociais no Brasil, v.2. São Paulo: Sumaré, 1995, p. 10.

${ }^{359}$ Alguns dos vultosos números, índices de crescimento e diferenciação das áreas, são mencionados por Renato Ortiz, "Notas sobre as ciências sociais no Brasil", p. 169; Luiz Werneck Vianna. "A institucionalização das ciências sociais e a reforma social; do pensamento social à agenda americana de pesquisa", p. 207; Octávio Guilherme Velho, "Processos sociais no Brasil pós-64: as ciências sociais". In.: Bernardo Sorj e Maria Hermínia Tavares de Almeida. Sociedade e política no Brasil pós-64. São Paulo: Brasiliense, 1984, p. 247.

${ }^{360}$ Renato Ortiz, "Notas sobre as ciências sociais no Brasil", p. 173.

${ }^{361}$ Idem, p. 169-170.
} 
ou não, ela se encontra sob égide da exigência da competência, da especialização e dos papers em larga escala.

Assim, as demandas profissionais vão pari passu às transformações que caracterizam o processo de modernização acelerada típico do regime militar, expresso na produção científica através da figura exemplar do profissional e do tipo de trabalho que passa a definilo. A decorrência evidente é a redução do trabalho à técnica e a adesão geral e irrefletida a uma concepção Sociologia que "se vincula à idéia de planejamento, coleta de dados para a realização de diagnósticos gerais e problemas específicos a serem enfrentados pelas empresas e pelo Estado"362 - o que elimina do horizonte tanto a perspectiva humanista e universalista, quanto as generalizações teóricas.

Do interior de um meio científico sujeito a esse processo emergiriam os intelectuais mais ilustres de nossa "nova esquerda". Os desdobramentos dessa modernização se fazem sentir no tipo de oposicionismo que elaboram, e por isso, sua compreensão requer que se esquadrinhe as condições das instituições de pesquisa e de resistência na década de setenta. Isso nos leva ao grupo de pesquisadores formados na Faculdade de Filosofia, Ciências e Letras, da Universidade de São Paulo, vinculado à mítica Maria Antonia, cujas atividades orbitavam em torno da Cadeira de Sociologia I, denominado genericamente como "escola paulista de sociologia" ${ }^{363}$, e que foi aposentado compulsoriamente em 1969 pelo regime militar. Parcela significativa dessa comunidade acadêmica forja seu próprio abrigo no Centro Brasileiro de Análise e Planejamento (Cebrap) - instituição idealizada anteriormente a essa data, e que, contudo, apressa sua constituição, em face da nova conjuntura política, para o que é primordial a liderança de Fernando Henrique Cardoso. ${ }^{364}$

O núcleo duro do Cebrap é revérbero de uma iniciativa que ficou consagrada, pela relevância alçada pelos pesquisadores que dela participaram. Trata-se do conhecido "Seminário de Marx": um grupo de estudos, formado em 1958, sob orientação de José Arthur Gianotti, cuja proposta de "leitura estrutural" dirigiria o grupo em sua procura por uma "lógica interna" d'O Capital de Karl Marx - procedimento que lhes renderia o epíteto de

\footnotetext{
${ }^{362}$ Idem.

${ }^{363}$ A questão da pertinência ou não do termo "Escola", seria tratada por Maria Arminda do Nascimento Arruda. "Trajetória singular: o acadêmico Florestan Fernandes". In.: Paulo H. Martinez (org.). Florestan ou o sentido das coisas; e José de Souza Martins. “A morte de Florestan e a morte da memória”. Estudos Avançados, n.26, v. 10. São Paulo, janeiro/abril, 1996.

${ }^{364}$ Bernardo Sorj. A construção intelectual do Brasil contemporâneo. Da resistência à ditadura ao governo FHC. Rio de Janeiro: Jorge Zahar, 2001, p. 35.
} 
marxólogos. ${ }^{365}$ Num momento em que o monopólio dessa leitura pertencia ao Partido Comunista, os jovens assistentes aclopavam o material de origem política ao tratamento acadêmico e inauguravam o chamado "marxismo universitário". Participando de sua fundação, aderindo posteriormente ao grupo, ou ainda estando em seu significativo raio de influência, originaram-se desse núcleo notáveis protagonistas do oposicionismo à ditadura militar, que viveram o desdobramento da modernização e o descompasso das incertezas do regime em sua atividade profissional, ao longo dos anos setenta. Entre outros nomes de destaque, poderiam ser lembrados, Fernando Henrique Cardoso, Francisco Weffort, Marilena Chauí, Paul Singer, Francisco de Oliveira, José Álvaro Moisés, José Serra, Maria da Conceição Tavares, Bolívar Lamounier.

O grupo passa por um período de maior isolamento, entre 1969-1974. Abre-se à atuação pública através da imprensa alternativa, especialmente em Opinião, a partir de 1973, participação esta que rotiniza a intervenção dos intelectuais em assuntos políticos, transformando o periódico num "eficaz veículo de aproximação entre o campo político e o território intelectual". 366 Determinante na constituição dessa intelligentsia, Opinião é considerado uma "experiência jornalística e intelectual inédita no Brasil", "espécie de órgão não-oficial de um campo oposicionista hegemonizado pela esquerda". ${ }^{367}$ Recorde-se ainda, a participação de muitos tanto no jornalismo alternativo, em que se mencione também Movimento, quanto no jornalismo comercial, como o provam Folha de S. Paulo, Senhor, Isto É. Na avaliação de Milton Lahuerta, a inserção em instituições como a Pontifícia Universidade Católica de São Paulo (PUC-SP) e a Sociedade Brasileira para o Progresso da Ciência (SBPC), especialmente após 1973, concorre para que os temas centrais se desloquem, da "retórica antiimperialista" para a "democratização, a organização dos trabalhadores e a distribuição de renda", perdendo a revolução "o lugar mítico que ocupava no léxico à esquerda, substituída por uma inusitada valorização da democracia". 368

A vitória eleitoral do MDB em 1974 assinala uma guinada: é a partir dela que a via eleitoral passa a canalizar muitas das forças oposicionistas ao regime militar. O MDB se estabelece como "um canal de expressão do sentimento oposicionista difuso, traduzindo-o através da contraposição entre autoritarismo e democracia." 369 Além disso, ela propicia,

\footnotetext{
${ }^{365}$ Roberto Schwarz. "Um seminário de Marx”. Novos estudos, n. 50. São Paulo, março 1998.

366 Intelectuais e transição, p. 183; Maria Hermínia Tavares de Almeida. Tomando partido, formando opinião: cientistas sociais, imprensa e política. São Paulo: Sumaré, 1992, p. 38.

${ }^{367}$ Intelectuais e transição, p. 183.

${ }^{368}$ Idem, p. 192.

${ }^{369}$ Idem, p. 204.
} 
inclusive entre os mais céticos, um sentimento de "mudança", que fomenta tanto a nascente concepção de "sociedade civil" em oposição ao Estado, quanto a reflexão acerca da representação política. Por conta disso, pode ser considerada um marco de ruptura na cultura política de esquerda, tonrnando-se decisiva para a centralidade que ganhará, no debate, a "questão democrática". 370

Em que se considere o papel do campo intelectual na conjuntura política, ressalte-se que, para tais eleições, o MDB, por conta de iniciativa de Ulisses Guimarães junto ao Cebrap, conta com a colaboração de alguns intelectuais para a elaboração do "Manual da Campanha de 1974". A partir dessa vitória, conforme Milton Lahuerta, "reforçam-se os vínculos entre os intelectuais e o partido, abrindo espaço para uma participação dos 'intelectuais enquanto massa'. Aos poucos, advogados, cientistas puros, filósofos, cineastas, dramaturgos, artistas plásticos, atores, economistas, estudantes" envolviam-se "numa luta de resistência democrática" 371 - sendo considerável a presença pública de diversas categorias de intelectuais, através de suas organizações profissionais, como por exemplo, a Ordem dos Advogados do Brasil (OAB) e a Associação Brasileira de Imprensa (ABI). Tudo se passa como se fosse garantido o espaço para os intelectuais na resistência ao autoritarismo e eles se afirmassem na luta pela democracia. Esse processo aumenta seu prestígio junto à opinião pública, na medida em que os vínculos com a esfera política, estabelecidos de diversas formas projetavam sua imagem de intelectuais públicos, intérpretes das transformações em curso. Formava-se assim um "partido informal, através do qual se fazia uma política diferente da tradicional"372, batizado pela célebre expressão, "partido intelectual" - designando o intelectual como "ator político coletivo", que reúne "uma faixa considerável das camadas cultas, é portador de crenças comuns, define estratégias conjunturais, tem seus líderes e adquire um caráter semi-organizado". ${ }^{373}$ Esse oposicionismo genérico, que permite a aproximação entre MDB e Cebrap, estreita-se a partir de 1974, e é intensificado pela candidatura ao senado, de Fernando Henrique Cardoso, em 1978.

Para Daniel Pécaut, a confluência de três fatores responde pela aproximação dos intelectuais à política e a centralidade do tema da democracia em seus debates: as estratégias de "racionalidade limitada", aprendidas na condição de oposicionistas de um regime ambíguo em sua abertura; a via eleitoral para a manifestação do oposicionismo; e o crescimento do

\footnotetext{
${ }^{370}$ Idem, p. 189.

${ }^{371}$ Idem, p. 149.

372 Idem, p. 149.

${ }^{373}$ Daniel Pécaut, Os intelectuais e a politica no Brasil, p. 260.
} 
próprio meio intelectual. Assim, passado “o período subseqüente ao AI- 5" os intelectuais são "protagonistas na luta pela liberalização. Proclamam sua competência, sua ‘profissionalização', seus interesses." ${ }^{374}$ Constituem-se como um ator político, para o qual a defesa da liberdade da profíssão coincide com a necessidade de eliminação de um regime que cerceia a seu métier - é a própria profissão que justifica a militância pela democracia.

Outrossim, ao engendrar um processo no qual "profissionalismo" se torna fonte de prestígio e legitimidade necessários para a intervenção pública o regime militar acaba por aproximar os intelectuais da sociedade, propiciando que a opinião pública reconheça os intelectuais como portadores de um "mandato" - reforçando os traços mannheimianos cultivados em sua auto-definição identitária. ${ }^{375}$ Daniel Pécaut chega a denominar a estratagema de "ideologia profissional”, que "substitui a ideologia demiúrgica. Impera o 'discurso competente'., 376 Junto à cidadania ilustrada, a profissionalização se torna um valor. No meio intelectual, "estabelece um princípio de classificação baseado em títulos universitários e uma separação entre produtores legítimos e amadores ou público",377 _ distinção que empresta sentido político oposicionista à militância intelectual pela autonomia, uma vez que, diante do regime, justifica a defesa de interesses, defende o controle dos "competentes" com relação a seu espaço profissional, toma como responsabilidade do próprio meio a delimitação dos requisitos da criação científica, e pode questionar a orientação governamental nesse campo. Dessa maneira, "a referência profissional constitui uma forma de os intelectuais se organizarem como um ator político capaz de, em nome de sua função na produção do conhecimento, remeter-se a uma racionalidade própria contra as opções de uma tecno-burocracia que pretende confiscar o uso da ciência em proveito de seus próprios projetos". 378

Portanto, não se pode dissociar essa militância da problemática institucional. A aderência dos intelectuais às respectivas instituições - sejam elas centros de pesquisa ou universidades - está no cerne desse profissionalismo que, portador de interesses legítimos, justifica-se como pilar de um oposicionismo ao regime que limita sua liberdade. No entanto, há uma crítica contundente à "ideologia profissional" e aos contornos que passam a delimitar “democracia". Não por acaso, viria, coevamente, de um intelectual cujo percurso parece então

\footnotetext{
${ }^{374}$ Idem, p. 195-196.

${ }^{375}$ Milton Lahuerta, Intelectuais e transição, p. 152.

${ }^{376}$ Idem, p. 280.

${ }^{377}$ Daniel Pécaut, Os intelectuais e a política no Brasil, p. 271.

${ }^{378}$ Idem, p. 271.
} 
marcado pelo signo da marginalidade institucional - que implica numa condição à margem daquele processo pelo qual a modernização autoritária atinge o coração do trabalho científico, Florestan Fernandes.

Diferentemente do grupo apresentado, ele não volta a travar relação orgânica com instituição alguma nesse período. A passagem pela Universidade de Toronto é marcada por um desconforto que resulta em seu pedido de demissão, e sua docência na PUC-SP é especialmente interessante por ressaltar sua adesão problemática à instituição. Além disso, no que se refere às relações do autor com aquele que foi o eixo da "militância intelectual", é válido lembrar que nem todos os intelectuais aposentados compulsoriamente se dirigiram ao nicho de resistência forjado no Cebrap. Florestan Fernandes não participa da fundação do centro e Octavio Ianni hesita, aderindo apenas um ano depois, sendo um dos primeiros, contudo, a se retirar da formação original. Ele alega que o centro não cumpre mais sua função de resistência, justificando assim sua saída. Já Florestan Fernandes, explica seu declínio por não aceitar o recurso ao capital estrangeiro para o financiamento do Cebrap, que, como se sabe, contou inicialmente com a Fundação Ford, para viabilizar suas atividades. ${ }^{379}$

Há, contudo, controvérsias. Com matizes distintos, Wagner de Melo Romão e Milton Lahuerta, entendem que Florestan Fernandes vivia um "descenso" de prestígio, enquanto Fernando Henrique Cardoso, uma "ascensão"; e por isso, o primeiro teria se esquivado do Cebrap, para não subordinar-se ao projeto do segundo. Seria, porém interessante questionar se o critério das disputas no interior do campo institucional pode ser, nesse momento, tão condicionante. Afinal os agentes encontram-se lançados fora de seu berço institucional, o sucesso da tentativa é incerto, e a crise desencadeada pela aposentadoria é equacionada segundo perspectivas individuais muito distintas - fatores que não podem ser desconsiderados. Além disso, é preciso ressaltar que, deflagrados os acontecimentos de 1969, Florestan Fernandes intensifica o processo de reflexão sobre a identidade política do intelectual - e é possível que a recente experiência do Cesit e seus projetos de pesquisa ligados ao financiamento privado tenham propiciado certo ceticismo com relação a ele. Se com o capital privado, só puderam desenvolver estudos para uma sociologia que explorasse os potenciais no interior da ordem existente, tal perspectiva revelaria uma incompatibilidade básica com a reflexão sobre a identidade intelectual imbricada com a problemática da revolução - eixo direcionador do percurso teórico e político no qual ingressa. Outrossim, essa recusa parece dar início a uma série de outras - a demissão voluntária no Canadá, a recusa

\footnotetext{
${ }^{379}$ Bernardo Sorj, A construção intelectual do Brasil contemporâneo, p. 32-36.
} 
proposta da Fundação Volkswagen, do convite da Universidade de Yale - que serão tratadas adiante. De qualquer maneira, para a problemática aqui desenvolvida, é preferível focar o ângulo crítico que essa marginalidade institucional lhe oferece para discutir as delicadas razões de sua recusa em participar do Cebrap.

Relativamente livre de coerções institucionais em stricto sensu, Florestan Fernandes produz sua obra segundo a dinâmica de sua própria reflexão crítica, mantendo-se isolado, ainda que não alheio, ao debate político travado no interior do esquema institucionalizado. Elimine-se do horizonte a relação entre obra e condições institucionais de produção imbricação na qual se processa esse "isolamento não alheio" - e não se compreende os seus posicionamentos. A militância do "partido intelectual" conjuga o ethos profissional, a instituição e a democracia. No caso de Florestan Fernandes, também são indissociáveis, a marginalidade institucional, a crítica à profissionalização do cientista tal como ela se processa, e a elaboração de uma concepção de democracia para a qual a "revolução contra a ordem” é um pré-requisito. Vejamos como se amarram esses elementos.

Grandes sínteses interpretativas não encontram condições propícias no interior da dinâmica profissionalizante descrita. É compreensível que os intelectuais tenham abdicado da elaboração de "grandes mitos unificadores para garantir a consolidação da nação", tão característica de seus antecessores. ${ }^{380}$ Sujeitos à dinâmica da fragmentação e do discurso competente da especialização, não elaborarão grandes ensaios interpretativos, empreendimento fora do alcance material e dos critérios de valorização profissional. Dessa perspectiva, é tardiamente que Florestan Fernandes traz à lume sua obra sobre a revolução burguesa. Entre seus pares, não encontramos interpretações do Brasil que conformem uma visão global, que confira significado a seus estudos particulares, circunstância que faz com que $A$ revolução burguesa no Brasil figure como última grande obra que procura apreender a história nacional, do século XIX até fins do século XX num eixo interpretativo. ${ }^{381}$ Enquanto na "nova esquerda", a "revalorização da democracia vinha de par com o abandono, mais ou

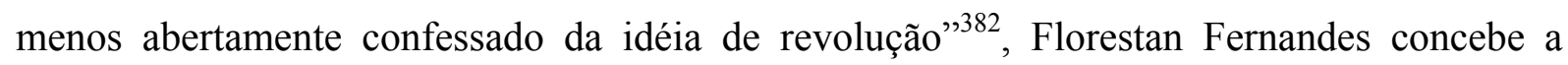
democracia como "revolução democrática" contra o modelo autocrático de desenvolvimento capitalista, pois em sua interpretação do Brasil, a questão atravessa a história nacional, no

\footnotetext{
${ }^{380}$ Daniel Pécaut, Os intelectuais e a política no Brasil, p. 196.

${ }^{381}$ Ver: José de Souza Martins, "A morte de Florestan e a morte da memória", p. 35-36.

${ }^{382}$ Maria Hermínia Tavares de Almeida. Tomando partido, formando opinião, p. 42; Caio Navarro de Toledo. "A modernidade democrática da esquerda: adeus à revolução?". Crítica marxista, vol. 1, n. 1. São Paulo: Brasiliense, 1994.
} 
campo social, político e econômico, e se coloca no presente enquanto uma escolha pela continuidade da contra-revolução burguesa ou pela revolução socialista. Daí, o esforço do sociólogo em se opor e apontar os limites do que considera ser "tão somente" uma resistência à ditadura.

Em Florestan Fernandes, democracia e revolução se articulam como condições recíprocas. Sua interpretação é um diagnóstico, e, portanto, definidora de seus posicionamentos, incluindo suas críticas atinentes à profissionalização. O autor, por estar relativamente fora do processo avassalador de modernização das instituições de produção científica, e ter se formado e estabelecido seu prestígio intelectual em fase distinta do desenvolvimento científico institucionalizado, sofre de estranhamento análogo ao de um nativo que, uma vez exilado, visse seu tempo e lugar de origem como um estrangeiro. Tal experiência se encontra na base de sua assídua crítica das condições de produção do trabalho científico às quais o "engajamento profissional" que tanto empolgou seus pares estava inexoravelmente submetido. De qualquer maneira, a "margem" parece ser uma posição favorável para observação das transformações abruptas pelas quais passa a produção científica, e, por isso, da mesma forma que seu isolamento não é alheio, sua marginalidade não é incólume.

Contrapor, aliás, a produção de Florestan Fernandes à do Cebrap salienta pelo menos três aspectos relativos às diferentes perspectivas resultantes da dinâmica que as preside: os temas, o tipo de trabalho, a relação com a política. Se no Cebrap havia acordo na denúncia às "tendências excludentes e socialmente injustas", havia temas-tabu, como "a questão do nacionalismo e das empresas públicas, as relações entre democracia, capitalismo e socialismo" - pois as divergências em torno deles fatalmente cindiriam a instituição num momento em que sua união era primordial. São, porém, temas que se tornaram os mais diletos de Florestan Fernandes. Quanto ao tipo de trabalho, se a excelente qualidade é característica da produção cebrapiana, no conjunto, verifica-se "a quase inexistência de esforços de síntese, de perspectivas globais”. E, no que tange às relações com a política, o Cebrap primou pela concepção do "campo intelectual como área diferenciada", no qual, por conta do compromisso com o espírito cientítico, "o argumento político-ideológico não podia ser apresentado como critério de validação", sendo seu o mérito de introduzir no manejo do marxismo um talhe profissional. ${ }^{383}$ Do ângulo de Florestan Fernandes, contudo, pensar as relações entre ciência e ordem capitalista, torna-se requisito do compromisso com a ciência

\footnotetext{
${ }^{383}$ Bernardo Sorj, "Estratégias, crises e desafios das Ciências Sociais", p. 318-325.
} 
social. É óbvio que não adota o critério ideológico para avaliação das produções intelectuais. Em sua reflexão, contudo, o "estritamente profissional” se torna tão político e nocivo quanto aquele "ideológico" refutado em nome do rigor científico, na medida em que reproduz uma ordem incompatível com a racionalidade científica. Essas diferenças convergem para uma divergência de base - o permanente autoquestionamento de um e a resolução $a b$ ovo do outro, uma vez que para o Centro as questões aí em jogo estavam institucionalmente resolvidas. Deslocamentos nessa solução ocorreriam apenas em meados dos setenta.

Isso porque, a produção intelectual, marcada pela crescente especialização, circunscreve os cientistas sociais em suas áreas: antropólogos, economistas, sociólogos, cientistas políticos. Concomitantemente, a modernização social e econômica propicia a multiplicação de problemas e seu tratamento específico, afeito às respectivas áreas em constituição, o que explica temáticas como: modelo econômico, inflação, carestia, moradia, desigualdade social, representação política. As cisões teóricas oriundas desse processo emergem em nível institucional, na medida em que reconhecem a possibilidade de se tornarem práticas políticas, ou seja, em função da conjuntura da distensão do regime. Dessa maneira, no Cebrap, as divergências teóricas não se manifestavam senão no plano estritamente intelectual, assim mantidas estrategicamente, priorizando a unidade institucional. Mas tomam dimensão institucional em 1975 e 1976, com a cisão do grupo, marcada pela saída de Lamounier e de Weffort - artífices, respectivamente, do Instituto de Estudos Econômicos Sociais e Políticos (Idesp) e do Centro de Estudos de Cultura Contemporânea (Cedec).

Se essas “diferenças de concepções não têm impacto político imediato", são decisivas “com o processo de reestruturação partidária de 1979" ${ }^{384}$ - quando personalidades como Fernando Henrique Cardoso e Francisco Weffort e Florestan Fernandes passam de suas orientações interpretativas distintas, e inserções institucionais diferenciadas, para tomadas de posições políticas em nível partidário, também distintas. Encontra-se em jogo, nessas escolhas, três concepções de democracia. No primeiro, "a perspectiva de uma ampla frente para consolidar a democracia, com a proposição do partido ônibus e com a recusa do ângulo classista, aderindo ao realismo"; no segundo, a aposta no "partido de classe, com a ênfase na identidade desse novo ator coletivo expressivo dos movimentos sociais"; já no terceiro, "a adesão à idéia de uma 'revolução contra a ordem' a partir dos excluídos." ${ }^{385}$ Como se sabe,

\footnotetext{
${ }^{384}$ Daniel Pécaut, Os intelectuais e a política no Brasil, p. 219.

${ }^{385}$ Milton Lahuerta, Intelectuais e transição, p. 236.
} 
Fernando Henrique Cardoso opta pelo PMDB, Francisco Weffort pelo recém nascido PT e Florestan Fernandes não adere a partido algum, não encontrando na reorganização partidária grupo que o atraísse. A mesma tradição intelectual uspiana de origem parece se fragmentar em diversas direções, pari passu a diferenciação do meio intelectual e os diferentes caminhos que os sujeitos seguem.

Entretanto, não se pode ocultar, ao contrário, é imperativo que se exponha o dilema no fundo dessa diferenciação, indagando, no âmbito afeito ao desse trabalho, ou seja, na historicidade das propostas de perfil intelectual desenvolvidas por Florestan Fernandes: como se coloca um intelectual que teve no centro de seu empenho profissional e político exatamente a conquista de condições de trabalho que, do ponto de vista material, são dadas por um regime ditatorial? A perspectiva segundo a qual a ética científica não é "contraditória com a mudança social" 386 nada tem de inédita e o acompanha mesmo desde o início de suas primeiras formulações acerca da intervenção sociológica. No entanto, se, crescentemente "é invocando normas e objetivos científicos que muitos docentes universitários, principalmente em São Paulo, se esforçarão para constituir uma frente coletiva de resistência à ditadura" ${ }^{387}$, tudo se passa como se as condições para que os intelectuais efetivamente exercessem seu papel numa sociedade moderna fossem engendradas por uma ditadura militar. É dramático, para Florestan Fernandes, ver as condições pelas quais se empenhava em 1962, presentes em 1974, sem que, contudo possa mais apostar naquele tipo de inserção programática, pois a forma pela qual elas se constituíram impossibilita que sejam tais intelectuais considerados agentes modernos senão, também eles, frutos da massificação. Trata-se, com efeito, de sonhos realizados de maneira perversa. ${ }^{388}$ Portanto, o autor não poderia se definir ou legitimar sua militância pela profissão - a questão da militância intelectual seria elaborada dentro de outra problemática. Não se trata de articular ética profissional com a atuação pública do intelectual no contexto de uma sociedade moderna, mas escandir as conseqüências, para a produção intelectual, de uma profissionalização alcançada através de um regime autoritário e de uma via massificadora.

Não parece casual que em seus depoimentos, o autor seja retroativo no tempo e prescritivo nas asserções, e, confessando o que supõe que deveriam ter feito, indique o que pretende que façam: “os intelectuais críticos deveriam ter forjado um intelectualismo radical, capaz de romper com os condicionamentos e os controles conservadores ao nível institucional e ao nível da sociedade nacional". O oposicionismo na gênese da "geração perdida" - ao

\footnotetext{
${ }^{386}$ Daniel Pécaut, Os intelectuais e a política no Brasil, p. 213.

${ }^{387}$ Idem.

${ }^{388}$ Renato Ortiz, "Notas sobre as ciências sociais no Brasil”, p. 172.
} 
conservadorismo interno e externo à instituição - parece insuficiente, na medida em que o desafio a uma força social não garante por si mesmo o vínculo com outra, que dê suporte efetivo à articulação entre "o ofício intelectual, a condição de cidadão e as polarizações ideológicas que impregnavam as correntes sociais em conflito". Tal insuficiência enunciada como equívoco pretérito, parece querer revelar ao presente limitações já constatadas, pois considera que não "era suficiente bater às portas dos 'setores mais esclarecidos' ou 'mais abertos à manipulação demagógico-populista' das classes dominantes; dos estudantes, dos diretórios acadêmicos o dos movimentos estudantis; dos sindicatos e das organizações operárias; dos partidos radical-liberais e socialistas; da imprensa liberal democrática." 389 Como não ver aí a presente "cidadania ilustrada" condicionando o olhar sobre o passado? A urgência por um radicalismo orientado ao socialismo, a recusa ao radicalismo meramente desafiador - em tudo é pertinente ao tipo de militância que convoca em meados dos anos setenta: não uma oposição à ditadura, através da adesão institucional à ordem; mas a negação da ordem através da subversão institucional.

É certo que o potencial emancipador da ciência na modernidade, na base de seu projeto inicial, não é colocado em dúvida. Seu problema é outro, e diz respeito à modernização conservadora, que fere e os valores modernos capazes de por "freios ao funcionamento desregulado e socialmente destrutivo do capitalismo",390 - manifesto no tipo de trabalho intelectual fomentado por ela. Por isso, três aspectos a que se opõe Florestan Fernandes devem ser destacados.

Em primeiro lugar, a perspectiva já apresentada, segundo a qual inserção institucional e vínculos de classe estão imbricados. A “ideologia profissional”, em seu dizer, lança o intelectual inexoravelmente num horizonte "mesquinho", de "classe média", e a ruptura com as "teias que o encerram na profissionalização" 391 se transforma em passo inicial de um envolvimento político conseqüente. É evidente que para nosso meio intelectual, cujo desconforto com relação à pertinência à classe média é conhecido ${ }^{392}$, as críticas de Florestan Fernandes são, no mínimo, constrangedoras. ${ }^{393}$ E, efetivamente, o estilo de vida dos intelectuais é beneficiado pelo "milagre"que propicia altos níveis salariais universitários,

\footnotetext{
389 “A geração perdida", p. 243.

390 João Manuel Cardoso de Mello e Fernando Novais. "Capitalismo tardio e sociabilidade moderna”, p. 607.

${ }^{391}$ A condição de sociólogo, p. 61.

${ }^{392}$ Daniel Pécaut, Os intelectuais e a política no Brasil, p. 196.

${ }^{393}$ Sylvia Gemignani Garcia, Destino impar, p.19.
} 
chegando em 1975, à inédita aproximação com o padrão norte americano. ${ }^{394}$ São conhecidas também as ambigüidades que atravessam o setor oposicionista de classe média, "sob o chicote e o afago" da "combinação de autoritarismo e crescimento econômico", saboreando um "amargo caviar no exílio". 395 Contudo, menos que a provocação de um eventual constrangimento moral, a preocupação de fundo nas advertências ferinas do autor dizem respeito às condições para o exercício autônomo do conhecimento, pois, para ele, "parece claro que se quer comprometer o intelectual com o nível de vida das minorias poderosas e com o espírito conservador, para neutralizá-lo." 396 Ademais, esse aspecto, que viria a se tornar um importante capítulo nos estudos sobre a modernização em âmbito cultural, se já era assinalado pelo autor em 1970, ainda era tangencial e marcada por um certo nacionalismo, que se opunha a qualquer identificação com padrões americanos de profissionalização ${ }^{397}$, não estando, em suma, no centro de sua reflexão. Entretanto, paulatinamente a "conexão" entre regime militar e modernização, e em particular no âmbito da produção científica e intelectual, seria levada ao cerne do esforço por forjar uma intervenção intelectual de resistência ao regime e de oposição à ordem, deslocamento reflexivo, em curso no corpus analisado nesse capítulo.

Em segundo lugar, a crítica a uma militância legitimada pelo prestígio está no cerne da contestação - pois ela lhe parece ser a própria reprodução, no plano da instituição, do modelo periférico de revolução burguesa, tornando a universidade, paladina da dinâmica autocrática. O prestígio do "discurso competente" estabelece uma visível distinção dos interlocutores na esfera do debate público, ilegítima de uma perspectiva que veja nessa diferenciação uma vertente classista, tributária da inserção intelectual naquela produção e consumo de massa. ${ }^{398}$ O debate sobre a voz política dos silenciados e a problemática da inserção do intelectual junto a eles - cujo discurso pode se aproximar daquele da "elite", em razão sua competência específica, diferenciada e hierarquizadora dos saberes - será dos mais complexos e matizados no período, figurando como paradigmática a reflexão de Marilena Chauí. ${ }^{399}$ Grosso modo, a problematização do "discurso competente", nesse sentido, aproxima-se das críticas que Florestan Fernandes faz ao "partido intelectual", centrado na bandeira da "profissionalização", fincada no cerne do que Florestan Fernandes parece querer abolir - a

\footnotetext{
${ }^{394}$ Daniel Pécaut, Os intelectuais e a política no Brasil, p. 274.

395 Maria Hermínia Tavares de Almeida e Luiz Weiz. "Carro-zero e pau-de-arara”, p. 333 - a ironia sobre o "caviar" é de Fernando Henrique Cardoso.

${ }^{396}$ A condição de sociólogo, p. 164.

${ }^{397}$ Idem, p. 160.

${ }^{398}$ Idem, p. 159.

${ }^{399}$ Cultura e democracia. O discurso competente e outras falas. São Paulo: Moderna, 1981.
} 
diferenciação, a especificidade que tributa legitimidade ao especialista do saber, no mesmo passo em que a elimina dos não especialistas. Por esse viés, encontra-se teoricamente mais afeito à vertente que se segrega do Cebrap e se reúne em torno do Cedec - ainda que não tenha com ela uma identidade de perspectiva suficiente que o leve ao PT em sua fundação.

Em terceiro lugar, a ciência social, tributária desse tipo de modernização, torna-se reprodutora da fragmentação social, através da especialização e da profissionalização. $O$ resultado é a perda da totalidade no horizonte dos intelectuais - algo em tudo divergente de suas expectativas. Como profissionais-intelectuais, mais uma entre tantas "categorias profissionais dos amplos setores médios criados pelo milagre”, a intelligentsia defende seus interesses, e se coloca "como parte interessada na grande redistribuição de condições materiais e imateriais, realizada no período 70-80". ${ }^{400}$ Assim, como contrapartida da impossível elaboração de sínteses interpretativas, tem-se a impossibilidade daquele fundamento social da síntese de perspectivas, a intelligentsia mannheimiana.

A problemática de Florestan Fernandes - como pode ocorrer e quais são as conseqüências da intervenção política do intelectual, sendo que as condições para sua atuação foram dadas por um regime autoritário - se movimenta no interior do esquema segundo o qual a modernidade periférica se realiza em sua irrealização. Dadas as condições materiais de formação de uma intelligentsia moderna, a especialização, a massificação e a profissionalização, aniquilam a perspectiva universalista e emancipadora, no seio da experiência histórica originária da modernidade. Gradativamente, o sociólogo se desloca da concepção na qual a instituição era requisito da autonomia científica, para outra, na qual o requisito para a autonomia é a própria ruptura com a instituição - em função de sua dinâmica reprodutora do poder autocrático, submetida à modernização massificadora, bem como dos vínculos de classe envolvidos numa adesão a ela. Essas contraposições aguerridas do sociólogo expressam sua pertinência solitária à "nova esquerda", na medida em que, se é desse terreno que germina a problemática sobre a qual se debruça, a reflexão é marcada por uma dissonância cuja insistência parece caracterizar a própria militância, que discorda e adverte os pares. O destaque do trecho seguinte serve para ilustrar o tom arredio de impossível demonstração, senão através de suas próprias palavras: "Onde o movimento socialista é fraco, ou ambíguo, o sociólogo fica livre, apesar do novo jargão 'crítico', 'militante' e 'participante', para dar pleno curso a novas modalidades de ritualização da investigação sociológica", assim, "continua a ser funcional para os interesses da ordem

\footnotetext{
${ }^{400}$ Daniel Pécaut, Os intelectuais e a política no Brasil, p. 280.
} 
estabelecida e converte-se no fiador de um sucedâneo pobre do antigo 'socialismo de cátedra', fomentando a corrupção burguesa em nome de Marx."

As preocupações de Florestan Fernandes dizem respeito ao fenômeno conhecido como "morte do intelectual". Entre nós, conhecido livro de Russel Jacoby é boa referência dos termos da discussão, afinada à desse trabalho, por esquadrinhar razões e conseqüências da profissionalização acadêmica, e do ocaso do intelectual como figura pública, a la Charles Wright Mills. ${ }^{402}$ Entretanto, a associação entre a "departamentalização" dos profissionais e a saída da vida pública não é consensual. Milton Lahuerta, por exemplo, defende a inadequação dela para o caso brasileiro, entendendo que aqui os intelectuais teriam atuado enquanto tal, justamente no momento culminante de sua profissionalização, no fim dos anos setenta. ${ }^{403} \mathrm{~A}$ constatação que faz da militância intelectual é verossímel, mas não parece suficiente para que se invalide alguns aspectos do que aponta Russel Jacoby: nem sempre a prosperidade da vida profissional leva ao enriquecimento da cultura pública, é freqüente os "profissionais constituam seu próprio universo" ${ }^{, 404}$, e a defesa de seus interesses numa esfera exterior à sua própria é o bastante para considerá-los militantes? Eis o que questiona, incansavelmente, Florestan Fernandes. Ademais, a coincidência entre o ápice da especialização e a intensa expressão pública dos intelectuais universitários no Brasil deve ser considerada também à luz do contexto político, como se procurou fazer nessa seção - do contrário, as considerações do autor em tela, que tem a constatação da militância profissional no início e não no final de sua crítica, tornam-se ininteligíveis.

Florestan Fernandes entende, em suma, que o cientista social se vê diante de uma opção entre capitalismo e socialismo, que redefine "o significado da objetividade e da neutralidade", e subordina, portanto, o sentido de uma "militância profissional" - termo que aparece uma única vez nos textos analisados, definido por tarefa que consiste em "resguardar a imaginação sociológica" de "qualquer forma sistemática de corrupção espontânea ou institucionalizada." $405 \mathrm{O}$ sentido dessa corrupção se coloca no interior da virada que projeta a realização do ideal de racionalização social para a sociedade socialista e se reverbera na figura de um profissional que adere ao socialismo para sua realização enquanto cientista - duas faces oriundas de um mesmo diagnóstico: o capitalismo monopolista e a contra-revolução burguesa

\footnotetext{
401 "Sociologia e socialismo". In.: A Sociologia no Brasil, p. 255.

402 Os últimos intelectuais: a cultura americana na era da academia. São Paulo: Trajetória Cultural/Edusp, 1990.

${ }^{403}$ Intelectuais e transição, p. 239.

${ }^{404}$ Os últimos intelectuais: a cultura americana na era da academia, p. 20-21.

405 "Sociologia e Socialismo", p. 257-258.
} 
são incompatíveis com a razão emancipadora. A "autêntica vocação sociológica crítica", capaz de romper "com uma visão do mundo intrinsecamente contra-revolucionária", só pode ser haurida da perspectiva socialista. ${ }^{406}$ A identificação entre o "profissionalismo" proposto e a adesão ao socialismo é o caminho que toma sua reflexão ${ }^{407}$, indicando a adesão a um tipo de conhecimento possível pela interação social, mas incompatível com a via institucional de produção científica - o que se torna matéria de muita reflexão pelos dilemas que essa escolha implica. Nosso último capítulo se dedica ao esforço do autor para solucioná-los.

\footnotetext{
${ }^{406}$ Idem, p. 256.

407 “Em busca de uma sociologia crítica e militante", p. 206.
} 
Capítulo III

Redefinição: Ciência e revolução (1979-1983) 
Prego a subversão da ordem poética, me pagam. Prego a subversão da ordem política, me enforcam.

Ferreira Gullar

Não estamos sozinhos e o trabalho intelectual também pode assumir as feições de uma guerrilha.

Florestan Fernandes 
“O que nos cabe fazer?” ${ }^{408}$ é a indagação obstinada de Florestan Fernandes ainda nos últimos anos que compõem o período a que nos dedicamos. A pergunta encerra confissão sincera de quem - tendo perscrutado através de seu vasto domínio teórico e de sua dramática experiência, os possíveis rumos a serem tomados - não encontra resposta. Com efeito, é assim que ele se dirige àqueles presentes na $31^{\text {a }}$ Reunião Anual da SBPC, em mesa redonda organizada por José Albertino Rodrigues, cujo tema era "os intelectuais e a repressão nos anos setenta". Consiste em matéria prima desse capítulo, a difícil resposta àquela indagação diante das vicissitudes desses anos.

A aposta política na ruptura com a ordem exige que elabore uma intervenção intelectual congruente a ela. Entretanto, a obstinação dessa busca não é suficiente para seu sucesso. Vimos que, dado o enquadramento do autor para a trajetória de sua geração, a intelligentsia se vê diante de uma bifurcação sem saída: a centralidade de sua atuação institucional a condena a ver inócuos os seus empreendimentos, e, por outro lado, a sociedade também não oferece sustentáculos suficientemente fortes nos quais ela possa se ancorar. Como se fossem abortados, impedidos de vicejar, intelectuais - modernos, como quis o sociólogo; revolucionários, como vislumbra o socialista - parecem, tal como a "burguesia conquistadora" e o "proletariado revolucionário", não serem frutos da modernidade periférica. No período que se abre, a habitual impetuosidade teórica não se contentaria com isso. Expandiria suas conclusões para o capitalismo monopolista contemporâneo - abarcando no esquema dessas o conjunto das nações capitalistas e seus respectivos intelectuais profissionais.

Sem saída, a reflexão não orbitaria nos impossíveis, contudo. Através das possibilidades que lhe apresenta, a história convoca rumos nela já inscritos. Nesses anos, Florestan Fernandes atuará como docente da PUC, editor da Hucitec e da Ática, intensificará suas incursões no jornalismo alternativo - e sofrerá o impacto da emergência dos de abajo no cenário político. “O que nos cabe fazer?” cala profundamente nos corações e mentes daqueles cuja trajetória se viu entre a bifurcação sem saída e a adoção da perspectiva de ruptura revolucionária com a ordem. Se o "subaproveitamento" social e institucional legava ao autor um "gravitar no vazio", o reconhecimento da "virtualidade histórica"409, obstinadamente procurada ao longo de décadas, não o leva à situação mais confortável. Florestan Fernandes

\footnotetext{
408 “Tarefas dos intelectuais na revolução democrática”. In.: Brasil: em compasso de espera, p. 50.

${ }^{409}$ Expressão de Gabriel Cohn, "Padrões e dilemas: o pensamento de Florestan Fernandes", p. 148.
} 
enfrentará os impasses típicos da tradição do marxismo clássico ${ }^{410}$ - oriundos da difícil e imperativa tarefa de distinguir entre o revolucionarismo que não aproveita as oportunidades e o cômodo reformismo, que, amarrado a elas, esvazia a si mesmo do propósito revolucionário. O caminho que vai da concepção do duplo abandono do sociólogo à que delimita papéis para o militante socialista marca a redefinição da identidade intelectual, acompanhada nesse trabalho. Como se entrevê em suas sinceras palavras -"alguns dos que estão me ouvindo estão certamente pensando que esta proposta encerra um puro delírio político"411 - o sentimento de quixotesco lhe acompanha em ambas.

\section{Desobediência civil: violação da lei institucional de autonomia.}

Indubitavelmente, os diversos perfis de intelectual atribuídos a Florestan Fernandes encontram lastro histórico nos inúmeros vínculos institucionais e políticos que estabeleceu. Especialmente no período a que nos dedicamos, contudo, suas refutas à inserção institucional são significantes, no mínimo do mesmo quilate, que tais vínculos - o conjunto delas ilumina suas tomadas de posição e sua adesão crítica a atividades, através das quais se insere e se diferencia no interior do meio intelectual e político. É momento oportuno para se escandir a complexa teia aí envolvida. Por essa razão, uma adesão e uma recusa institucional estarão no horizonte dessa seção: sua docência na PUC-SP e a sofreguidão de não retornar à USP, por ocasião da Anistia política em 1979. Ambas estão no cerne da noção de desobediência civil e marcam novos passos da reflexão sobre a condição intelectual.

Quando, em 1969, Florestan Fernandes não aderiu ao Cebrap, talvez não soubesse como os rumos que tomariam suas reflexões estariam marcados por isso. Tendo já os assinalado, interessa agora ligar essa recusa a uma série de outras, cujas justificativas compõem um quadro significativo. É possível se encontrar relato íntimo de suas escolhas e renúncias nas cartas de Bárbara Freitag. Em 22/04/1970, o sociólogo lhe confessa, acerca da oferta recebida pela Fundação Volkswagen: "as cicatrizes" "me tornam um tanto relutante em aproveitar as vantagens que minha posição me proporciona", por isso, no "caso da dotação oferecida pela Fundação Volkswagen”, vou “fazer o mesmo que já fiz com ofertas análogas

\footnotetext{
${ }^{410} \mathrm{Na}$ acepção conferida ao termo por Perry Anderson em Considerações sobre o marxismo ocidental. Nas trilhas do materialismo histórico. São Paulo: Boitempo, 2004.

411 “Tarefas dos intelectuais na revolução democrática”, p. 53.
} 
da Fundação Ford”. O paradoxo: "tentar ser 'racional' por vias irracionais." ${ }^{412}$ Decerto, numa dinâmica dentro da qual "as criaturas se valorizam através do mercado", não passa de "uma aberração" ${ }^{413}$, a razão que atenda a outros fins - daí o autor concluir por sua irracionalidade.

No declínio dos convites há um ímpeto para a refuta de atividades incompatíveis com uma concepção de trabalho intelectual que não se enverga diante da racionalidade capitalista. Outros fins, adversos aos do mercado, reincidem ao decidir pela não permanência no Canadá. Apesar de reconhecer as ótimas condições de trabalho oferecidas, demite-se voluntariamente em 1972 do cargo de professor-titular na Universidade de Toronto, para retornar ao Brasil. É evidente que as condições de vida e pesquisa científica propiciadas pela Universidade de Toronto encerram o problema moral vivido pelo autor, na base da experiência pessoal que fomenta o tipo de crítica que vem sendo apresentada. Não por acaso, são poucos os relatos sobre suas atividades no Canadá, e, quando vem à tona, o desconforto em relação aos benefícios oferecidos pelo capital estrangeiro e pelo circuito universitário internacional são contrapostos à conduta defendida pelo autor, em cortantes asserções, dentre as quais, a mais forte talvez se encontre no final da entrevista $A$ condição de sociólogo - em que não deixa de comparecer algum resquício da disciplina austera que procurava imprimir ao trabalho acadêmico: para a classe média "sobra pouco tempo para a atividade intelectual", pois comprimida "entre outras exigências, nascidas das atividades mundanas, do consumo conspícuo e dos fins de semana sedutores", envolvido nisso, o intelectual torna-se "um pobre diabo." ${ }^{414}$ É evidente que também tem seu lugar na elaboração dessa conduta, a trajetória de ascensão econômica e social de Florestan Fernandes, aspecto que se não é contemplado pelo escopo desse trabalho, fica saliente no percurso das fontes visitadas, pela reincidência de suas declarações acerca de seu dilema moral. ${ }^{415}$ Ressalte-se ainda, que, como fruto desse incômodo, é certo que seu retorno não é gratuito; e, no entanto, também não é calculado, estando marcado pela incerteza quanto ao sentido político de sua atitude. ${ }^{416}$

Outra recusa viria se somar às assinaladas. No primeiro semestre de 1977, Florestan Fernandes lecionou na Universidade de Yale. Na ocasião, recebeu "um convite para assinar um contrato, por três anos". Novamente, relata: “escrevi para casa para sondar as reações da

\footnotetext{
412 "Florestan Fernandes por ele mesmo", p. 149.

${ }^{413}$ Idem.

${ }^{414}$ A condição de sociólogo, p. 164-165.

${ }^{415}$ Ver, especialmente, "Florestan Fernandes por ele mesmo", p. 148-149, p. 169.

${ }^{416}$ A natureza sociológica da Sociologia, p. 14; “A pessoa e o político”. In.: Nova Escrita Ensaio. Ano IV. N. 8. 1981, p. 22.
} 
família", mas mesmo antes de obtê-las, "resolvi não aceitar." ${ }^{417}$ A recusa ao convite para trabalhar em Yale encontra, então, justificativa em reflexão localizada pelo autor nos depoimentos presentes em A Sociologia no Brasil: cuja leitura testemunha "que não tenho liberdade para agir de outra forma. Não posso dizer uma coisa e fazer outra". ${ }^{418}$ A razão para não permanecer na universidade liga-se ao compromisso com a coerência, conferindo sentido e dever à desvinculação institucional. Conclui o autor: "meu ciclo institucional está encerrado. Poderei fazer algo aqui ou ali, mas retomar o trabalho acadêmico, intensivo cerrado não me atrai mais."

Não se deve supor que Florestan Fernandes, como Charles Wright Mills entoasse uma "ode ao fracasso enquanto garantia de integridade". ${ }^{420}$ Entretanto, uma desconfiança crescente e sistemática com relação ao prestígio como signo da qualidade do trabalho intelectual - que, oriundo menos de uma dinâmica científica de produção e mais da ingerência e invasão de parâmetros capitalistas de produção, é associado à condição de classe média, assumida pelos intelectuais - parece figurar na disposição para esses esquivos, ainda que sob diversas justificativas e em diversos níveis de elaboração teórica. Ela se encontra na recusa, tanto dos financiamentos da Fundação Ford e Volkswagen, quanto das cômodas condições oferecidas aos pesquisadores de renome pelas instituições internacionais - como a Universidade de Toronto e a Universidade de Yale.

Essas recusas indicam, ademais, que Florestan Fernandes se vê diante de sua própria condição de dissidente intelectual, marginalizado, contudo, de prestígio inconteste - que goza de reconhecimento, e tem aí uma fonte de privilégios. Autoconsciência no fundo de sua indignação: "O que poderia eu fazer? Aceitar uma posição que consolidava meu 'nível internacional' e pela qual me acomodaria à autodefesa internacional da ordem capitalista? $\mathrm{Ou}$ conduzir-me como uma espécie de 'cruzado sem uma ordem monástica'?" ${ }^{421}$ - e que exige equacionamento, num nível prático, evidente nas recusas, e num nível teórico, saliente nessa indagação. O dilema é assinalado: as benesses do prestígio ou a militância inócua. No primeiro lhe falta sentido político, no segundo lhe falta abrigo institucional. Os limites do capitalismo, alçados na reflexão pela crítica, que se dirige à instituição como a própria representação do limite da ordem, compreende a autonomia científica que nele se configura

\footnotetext{
417 "Florestan Fernandes por ele mesmo", p. 162.

${ }^{418}$ Idem, p. 162.

${ }^{419}$ Idem.

${ }^{420}$ Russell Jacoby, Os últimos intelectuais: a cultura americana na era da academia, p. 108.

${ }^{421}$ A natureza sociológica da Sociologia, p. 13.
} 
como ilusão, na medida em que é tutelada pelo que a ordem comporte de negatividade que não a destrua.

Seria no dramático episódio da Anistia política de 1979, que essa perspectiva se realizaria cabalmente, com o requinte típico do autor, de sintetizar na própria conduta os dilemas gerais e as manifestações particulares do capitalismo na periferia. Num trabalho como esse, em que a problemática principal aglutina a interpretação do autor para os processos globais às considerações da conjuntura, é proveitoso que, a partir de sua posição com relação à Anistia, fique sinalizada também sua perspectiva quanto à abertura política. Para ele, a Anistia, se está relacionada a um contexto geral de luta política, é "alguma coisa que a ditadura é obrigada a fazer exatamente para se conservar". ${ }^{422}$ Por isso, não poderia aceitá-la "As razões que levaram a ditadura a nos expulsar da universidade subsistiam, a ditadura não estava abatida", além disso, "a ditadura que nos expulsou da universidade" assumia, "ela própria, a iniciativa de nos recolocar lá" - a abertura lhe parecia "um processo falso", e voltar, "um problema político". ${ }^{423}$ Nesse sentido, a anuência da ditadura militar aos intelectuais dissidentes na Universidade não passaria de uma estratégia entre tantas assinaladas no longo processo de distensão e abertura, pelas quais ela legitima a si mesma, no mesmo passo em que pretende normalizar suas funções na institucionalidade democrática. ${ }^{424}$ Não há dúvidas acerca da resposta à indagação: "O que (o retorno à USP) resolvia ? O nosso problema, o problema da universidade ou o problema da própria ditadura?" ${ }^{425}$ Nos termos do autor, a Anistia resolve os problemas do próprio sistema político. Ademais, é válido pontuar que o reconhecimento de delicadas relações pessoais que esse e outros episódios envolvem não as torna objeto de análise. A opção desse trabalho é primar pelas orientações políticas envolvidas, considerando também o cuidado do autor em destacar a proeminência delas em relação às questões pessoais. $^{426}$

Dessa maneira, por reconhecer traços em sua própria condição daquilo que refuta como condição para o trabalho científico legítimo, o autor calcula sua conduta dentro de um espaço que possa recusar seu próprio prestígio, opor-se à ordem, e particularmente à sua concretização no modelo político que representa a ditadura militar. Se essa problemática está

\footnotetext{
422 "Entrevista concedida a José Albertino Rodrigues, UFSCar". Publicada em setembro / outubro de 1983. In.: Cientistas do Brasil. Depoimentos. Edição comemorativa dos 50 anos da SBPC, 1998, p. 73.

${ }^{423}$ Idem.

${ }^{424}$ Segundo as longas prospecções sociológicas que concluem A revolução burguesa no Brasil, a distensão expressa o propósito de permanência e incorporação do "modelo autocrático" à estrutura de funcionamento normal do Estado. Ver especialmente, p. 350 e segs.

425 "Entrevista concedida a José Albertino Rodrigues, UFSCar", p. 73.

${ }^{426}$ Idem.
} 
no cerne da recusa em retornar à USP, a adesão aos quadros da PUC-SP em 1977 também é marcada por ela. Com efeito, é esmerado naquela segunda parte d'A Sociologia no Brasil, de que lançou mão para explicar sua recusa a Yale, que o autor justificaria o aceite do convite: “comecei a lecionar na PUC, tentando pôr em prática a linha de trabalho que recomendo". 427

É indubitável que nesse livro pululam indicações para uma "linha de trabalho" - e nelas se encontrem diretrizes da inserção de Florestan Fernandes na PUC-SP. Considere-se para tanto, também a circunstância de que o próprio convite ocorra paralelamente à produção desses depoimentos: sendo convidado a lecionar na PUC-SP quase simultaneamente ao momento em que faz afirmações nada canônicas acerca da instituição universitária, o vínculo estabelecido não poderia recuperar seu padrão pretérito de adesão institucional, senão $a b$ ovo, definir-se crítico e anti-canônico. Esse aspecto deve ser contemplado junto à produção do autor como docente da PUC-SP e ao sentido conferido à desobediência civil - designação com a qual sintetiza sua atuação - para que se compreenda o papel dessa atividade nos rumos da reflexão sobre a condição do intelectual. ${ }^{428}$ Vejamos.

A primeira questão que poderia se colocar diz respeito à coerência entre as recusas institucionais de Florestan Fernandes, as sugestões deixadas por seus depoimentos quanto à necessidade de ruptura com as instituições, e a adesão aos quadros da PUC-SP. Não se pode deixar de assinalar que a instituição era um dos redutos de agrupamento dos setores intelectualizados, que, sob o escudo de D. Paulo Evaristo Arns, opunha-se à ditadura militar. Esse aspecto salienta que o ambiente e os propósitos da vida universitária em nada se assemelhavam ao modelo de universidade e ciência em constituição que caracterizava a USP e o projeto acadêmico político de Florestan Fernandes. Não ilumina, entretanto, a razão de sua adesão, uma vez que o mesmo propósito definia outros espaços, como o Cebrap, ou a Folha de S. Paulo ${ }^{429}$, aos quais não aderiu nesse momento. As razões se manifestam em outro âmbito.

A singular inserção institucional de Florestan Fernandes se expressa lapidarmente no estranhamento confesso com relação à prática que ele mesmo enseja. No que se refere à condição de docente, afirma: "Poderia parecer que deveria ficar contente. Não fiquei. A minha reação é melancolia. Perdida a identidade profissional, o ensino não traz aquelas

\footnotetext{
427 "Florestan Fernandes por ele mesmo", p. 164.

${ }^{428}$ Aproveito o ensejo para registrar meu agradecimento à entrevista que Miguel Chaia, artífice desse abrigo institucional, gentilmente me concedeu.

${ }^{429}$ Conforme análise de Carlos Alberto Furtado de Mello: Imprensa e democracia: a transformação da Folha de S. Paulo e a criação do Partido dos Trabalhadores. São Paulo: PUC-SP, Departamento de Ciências Sociais, dissertação de mestrado, 1996.
} 
compensações tão maravilhosas" - pensa que seu "momento já passou" e a "magia se quebrou há tempo". ${ }^{430}$ A seus alunos confessaria em aula inaugural: "Não pretendia voltar nem à condição de professor, nem aos temas acadêmicos". 431 O desencanto é passo que leva à crítica, e também se mescla ao desarranjo da identidade, como faces de um mesmo processo doloroso - e talvez por isso, ela seja ressaltada na apresentação pessoal que abre o curso. Trata-se de perda de referências da vida intelectual, profissional e política - âmbitos que de alguma forma eram tangenciados, em diferentes níveis, por sua vinculação com a instituição. $^{432}$

À desilusão em relação à atividade profissional do sociólogo, que preside as declarações com relação ao papel docente, soma-se o desconforto com relação ao trato dos temas, marcado pela não especialização. As ressalvas são uma constante nas publicações oriundas dos cursos lecionados. Em Apontamentos sobre a "teoria do autoritarismo" afirma: "Na verdade, não sou cientista político nem tenho credenciais" para "um curso sobre matéria tão complexa." ${ }^{, 43}$ Reserva da mesma espécie encontra-se na abertura de seu famoso curso sobre a revolução cubana. Segundo ele: “o assunto transcendia minhas qualificações" "434, e, por isso, “devo justificar-me. Não sou especialista em Cuba e uma revolução tão complexa quanto a revolução cubana exige mais que uma improvisação" "435, portanto, "saliento que este curso possui um caráter elementar e introdutório" e insistirá nos "limites que decorrem de uma sondagem exploratória”. ${ }^{436}$ Entretanto, a relevância e o propósito políticos colocam o tema em pauta, e, portanto, justifica o enfrentamento, "pelo menos até que se consiga abrir um espaço adequado para o estudo do socialismo no mundo moderno, em geral, e de Cuba socialista, em particular, dentro das atividades de ensino e de pesquisa na universidade brasileira". ${ }^{437}$ Assinale-se de passagem que as aulas sobre a revolução cubana também foram ministradas como curso livre, no próprio prédio do Departamento de Ciências Sociais da USP, no segundo semestre de 1979, atendendo ao convite do centro acadêmico - o que sugere

\footnotetext{
430 "Florestan Fernandes por ele mesmo", p. 164.

${ }^{431}$ A natureza sociológica da Sociologia, p. 13.

${ }^{432}$ Notar que essa perda é presente, a despeito de quase dez anos passados, como o deslize do tempo verbal no sublinhado sugere: "se fui alguma coisa em minha vida, fui um universitário", e "no sentido pleno da palavra. A tal ponto que quando deixei de ser universitário, fiquei desarvorado. Eu não sei para onde vou. Estou numa crise que é psicológica, é moral, é política. Em grande parte porque, na medida em que não tenho grande interesse em ser professor de sociologia no exterior, e não podendo sê-lo aqui, perdi um ponto de referência e de identidade". A condição de sociólogo, p. 70.

${ }^{433}$ Apontamentos sobre a "teoria do autoritarismo", p. XIX.

${ }^{434}$ Da guerrilha ao socialismo: a revolução cubana. São Paulo: T. A. Queiroz Editor, 1979, p. 3.

${ }^{435}$ Idem, p. 4.

436 Idem.

${ }^{437}$ Idem, p. 3.
} 
um retorno não oficial à célula mater, especialmente, se tivermos em vista que um pseudoaluno, agente da polícia política, assistiu a todo o curso, e o registrou detalhadamente. ${ }^{438}$

O estranhamento saliente nesse cuidado constante se liga a uma prática inédita e avessa àquela que define seu percurso inicial. Se em sua primeira inserção institucional esteve ligado à tendência mais adiantada da modernização e institucionalização das ciências sociais em curso; aqui se coloca na contramão do processo corrente, na medida em que sua não especialização consiste numa subversão dos parâmetros valorativos, definidos em torno da figura do especialista profissional. Além disso, a dúvida persistente parece indicativa de tempos de crise em que o sentido da própria atividade escapa ao sujeito e, exatamente por isso, este o elabora persistentemente. Não há prefácio dessas publicações no qual não conste a derradeira indagação - "por que publicar tais reflexões?" 439

Não se esgota o prisma de significações dessa prática sem considerar a mescla de estilos que também subverte os ditames da especialização em voga. Reincidem as ressalvas e as justificativas, indicativas de que o autor não está incólume às metamorfoses no estilo de sua reflexão. No atinente a esse aspecto, sobressai, contudo, uma ambígua conclusão, acerca da necessidade do esforço e da defíciência do resultado: "Nunca tentara (...) combinar a necessidade de dar aulas com a vontade de escrever um livro", e "depois de feita a experiência", ela "me parece errada de uma perspectiva pedagógica. Um texto demasiado enxuto para livro, e demasiado extenso como roteiro de aula, acaba sendo mau para a eficácia didática do professor". ${ }^{440}$ Entretanto, a falha do âmbito pedagógico se coloca ao lado de uma compensação: “A aspiração de escrever um ensaio", acerca d'A natureza sociológica da Sociologia "vem de longe". Contudo, "somente agora - e combinando livro com aula - posso levar a cabo a tarefa. Se tudo fica relativamente ambíguo (não temos um livro nem um conjunto de aulas, estritamente falando), o fato de voltar a idéias tão essenciais para mim, com a obrigação fundamental do diálogo, tem uma importância psicológica e política marcante. ${ }^{.441}$ A mescla entre livro e aulas se liga ao imperativo primeiro que subordina a adoção do estilo. Tal "obrigação" exige a mescla, que propicia ao autor o "diálogo" político possível nas condições em que se encontra.

\footnotetext{
${ }^{438}$ Esse material pode, atualmente, ser encontrado o Arquivo do Estado de São Paulo e consiste em parcela considerável da documentação reunida no prontuário de Florestan Fernandes.

${ }^{439}$ Apontamentos sobre a "teoria do autoritarismo", p. XX; A natureza sociológica da Sociologia, p. 10; Da guerrilha ao socialismo: a revolução cubana, p. 1.

${ }^{440}$ A natureza sociológica da Sociologia, p. 11.

${ }^{441}$ Idem, p. 10.
} 
No tom de "prestação de contas" de suas observações, o passado parece emergir como interlocutor, expressando uma comparação implícita com a atividade acadêmica, desempenhada entre os anos quarenta e meados dos sessenta na USP, tendo sob seu comando a Cadeira de Sociologia I. Os sensíveis incômodos - com relação ao papel docente, à não especialização e à mixagem de gêneros que preside a reflexão - convergem para a delimitação da noção de "desobediência civil" com a qual o autor confere sentido à atividade na PUC-SP. Tudo se passa como se aí se elaborasse uma violação da autonomia institucional, representada modelarmente pelo próprio autor no passado, ao esquadrinhar seu modelo de formação do pesquisador e do professor na universidade, bem como a profisssionalização e a institucionalização das ciências sociais, cerradas pela precisão da linguagem especificamente científica.

Considerando a crítica que vem sendo objeto de exposição, a adesão aos parâmetros de prestígio profissionais, ou qualquer outra espécie de vínculo com a instituição universitária seriam improváveis. Primando pela coerência na qual se declara empenhado, a atividade no interior da instituição é legítima justamente por promover a violação assinalada, entendida enquanto subversão de uma autonomia institucional pautada nos valores correntes expressos na figura do profissional-especialista - dando forma possível à negação da ordem, a partir da instituição. ${ }^{442}$ Por isso, é a ela que se dirige precipuamente a noção de "desobediência civil", expressão de suas concepções políticas, traduzidas na inserção na PUC-SP. Pode-se ressaltar novo parentesco com o episódio da "Autodefesa". Ambos negam a ordem das coisas e forjam uma resistência a partir de uma prática intelectual e de um abrigo institucional compatível com ela. Entretanto, a "Autodefesa" se alicerçava numa perspectiva de instauração da ordem moderna com base na autonomia institucional, pautada num ascetismo político para o abrigo da ciência e para a defesa de sua integridade em face da intervenção militar. Como se fosse invertido o sentido de autonomia, a "desobediência civil" alude à violação dela como subversão da ordem a partir da instituição, uma vez que o asceticismo político como fundamento da autonomia na instituição se revelou uma irrisão. ${ }^{443}$ A suposição da instituição como morada do conhecimento autônomo, imperativa, portanto, daquela respeitosa conduta com relação à estrita esfera competente cede a cena à idéia de que autonomia e liberdade

\footnotetext{
${ }^{442}$ É latente uma questão quando se fala da inserção de Florestan Fernandes na PUC-SP: sua histórica querela com as escolas confessionais e privadas nos anos cinqüenta, por ocasião da Campanha pela Escola Pública. (José de Souza Martins, "A morte de Florestan e a morte da memória", p. 41). Para o próprio sociólogo, a questão confessional é menos relevante que a possibilidade de "mostrar que nós podíamos sobreviver trabalhando, e aceitando as condições que nos eram generosamente oferecidas pela PUC". ("Entrevista concedida a José Albertino Rodrigues, UFSCar", p. 73-74).

443 "A geração perdida", p. 229.
} 
intelectual implicam numa instituição que comporte seu próprio questionamento e a explicitação das posturas políticas a que inexoravelmente expõe os estudantes, posto que a "neutralidade institucional" é "neutra do ponto de vista das ideologias consagradas pelas estruturas de dominação vigentes." 444 Talvez por isso, a PUC-SP represente um espaço institucional que lhe pareça realizar a verdadeira liberdade na universidade, na qual nunca houve interditos teóricos, como, "Não use Marx, não use Lênin" ou "não trate de conflito de classes, de luta de classes", na verdade, "Eu dei o ensino mais militante possível, às vezes até parece ensino de escola de partido" 445 - o que não implica em: "estabelecer uma relação direta entre ideologia, ciência e atividade didática", mas oferecer ao estudante "diversos tipos de cursos com impregnação ideológica muito variável". ${ }^{446}$

Qual seria o significado dessa nova atividade institucional, no atinente à reflexão sobre o intelectual? Pode-se afirmar, sinteticamente, que essa nova espécie de inserção institucional media a mudança de relação com a própria teoria, pois a modalidade de autoquestionamento que emerge na produção do sociólogo na PUC-SP é uma espécie de crítica teórica. Heloísa Fernandes apreende essa transformação, ao prefaciar Apontamentos sobre a "teoria do autoritarismo", entendendo que ele começa "pela crítica contundente e definitiva não só à própria teoria que empresta realidade ao conceito", como "denuncia as forças sociais subjacentes a esta teoria, forças através das quais a defesa da ordem se instaura no horizonte intelectual do cientista político." Trata-se de um tipo de abordagem cuja problemática se dirige não apenas à extração das conseqüências políticas das posturas teóricas, mas procura o fundamento social e político no qual se sustenta a teoria. Por isso, "denuncia a problemática do adversário", cuja elaboração conceitual exprime o comprometimento com "a crítica liberal burguesa e cujo verdadeiro oponente não é, de fato, a ditadura fascista, mas a revolução proletária e a democracia popular". ${ }^{447}$

Com efeito, seus trabalhos passam a tomar a própria teoria por objeto. Em detrimento do procedimento básico do sociólogo, da "aplicação" da teoria; a crítica teórica, a busca por sua natureza política, torna-se o princípio do exame da mesma. Se do ângulo de sua relação com a teoria sociológica, capítulo a parte poderia ser desenvolvido, é válido mencioná-lo. São constantes as confissões: de certa menoridade do autor com relação a seu texto; de uma crise com relação à produção escrita; do caráter menos cerrado das elaborações em comparação

\footnotetext{
${ }^{444}$ A natureza sociológica da Sociologia, p. 10.

445 “Entrevista concedida a José Albertino Rodrigues, UFSCar", p. 74.

${ }^{446}$ A natureza sociológica da Sociologia, p. 10.

${ }^{447}$ Heloísa Fernandes. "Prefácio". In.: Apontamentos sobre a "teoria do autoritarismo", p. XII.
} 
com as do início de sua carreira. ${ }^{448}$ Ao que parece, o "recuo crítico com relação ao ensaio" de que fala Maria Arminda do Nascimento Arruda parece se estender a outros livros, além de $A$ revolução burguesa no Brasil, denotando, ao mesmo tempo, o distanciamento do autor em relação ao "modelo de exposição das idéias"449 pautado pelo controle rigoroso do texto e da teoria, a crise com relação à instituição que o abriga e o questionamento de sua validade.

A crise com relação aos parâmetros institucionais e a subversão dos mesmos em sua "desobediência civil" se expressam nesse novo trato da teoria - conformando os traços de sua crítica teórica. A não especialização oferece outra perspectiva de apropriação que não o uso teórico dos conceitos em stricto sensu, a mixagem do estilo é favorável à exploração dos sentidos da teoria, menos fechado que sua "aplicação", e aquele desencanto na base da experiência propicia a condição básica de redução da teoria a objeto de análise. A passagem pela PUC-SP é fundamental, portanto, não como um retorno "menos intenso" à universidade. Mas por promover a condição de negação da ordem no âmbito da esfera institucional, na qual o autor liga o questionamento da instituição à crítica do processo de produção teórica pari passu à sua própria produção metateórica. Trata-se de passo decisivo para a elaboração de uma nova proposta de intelectual alicerçada em outro processo de produção de conhecimento.

Dentre os cursos que leciona, aquele no qual o princípio da crítica teórica orienta o trato dos conceitos, apreendidos em sua historicidade, atravessada pela luta de classes resulta na publicação A natureza sociológica da Sociologia, e foi ministrado no primeiro semestre de 1978. Nele, a crítica delimita o terreno em que germina a redefinição da identidade intelectual em curso. É imperativo, por isso, que nos detenhamos.

A denominação original da disciplina, "A Sociologia numa era de crise da civilização" evoca, no interior de sua produção, A Sociologia numa era de revolução social e no interior de sua bagagem sociológica, o clássico de Mannheim, A Sociologia numa era de reconstrução social. Contudo, não repõe as áureas expectativas na base da produção dessas obras. ${ }^{450} \mathrm{O}$ bosquejo das condições que propiciam o conhecimento e a concepção do social orienta a reflexão acerca da crise de civilização - noção corrente em seus escritos para

\footnotetext{
448 "Introdução" (Lênin), p. 49; "Em busca de uma Sociologia crítica e militante", p. 124; "A geração perdida", p. 216; "Florestan Fernandes por ele mesmo", p. 159; A Sociologia no Brasil, p. 7; A natureza sociológica da Sociologia, p. 9; Brasil: em compasso de espera, p. 2.

${ }^{449}$ Metrópole e cultura, p. 213.

${ }^{450}$ À auto-referência no interior de sua obra, poderia ser dedicado um estudo à parte - o procedimento é intenso no período, e se vincula à reposição "em um contexto histórico novo" de "velhas preocupações" (A Sociologia no Brasil, p. 123). A comparação entre "Sociologia como afirmação", de 1962, de A Sociologia numa era de revolução social, e "Sociologia como contestação", de 1976 - textos que guardam uma analogia com relação à sua própria organização e paradigmáticos da publicação que integram - seria um dos pontos altos dessa análise.
} 
sinalizar o acirramento da luta de classes e de "conflito de vida e morte entre capitalismo e socialismo". ${ }^{451}$ A epígrafe da publicação não é de menor significação: "Os economistas nos explicam como se produz nestas relações dadas, mas o que eles não nos explicam é como estas relações se produzem, isto é, o movimento histórico que as faz nascer". ${ }^{452} \mathrm{O}$ conhecido jargão de Miséria da filosofia aqui se prestaria a confessar a ambição do autor: apreender na raiz, portanto, radical e historicamente, a existência do conhecimento sociológico.

Para Maria Arminda do Nascimento Arruda, n'A natureza sociológica da Sociologia, o que se observa é a "revisão das suas posturas", destacando-se "sua dificuldade em reconciliar-se com as aspirações e crenças do passado." ${ }^{453}$ Com efeito, há aí um modus operandi distinto e oposto, se comparado ao d'A Sociologia numa era de revolução social. É em definitivo invertida a perspectiva que a preside, na qual, partindo dos problemas e dos impasses da inserção do intelectual, chega às suas responsabilidades para solucioná-las. Em $A$ natureza sociológica da Sociologia, ele parte das responsabilidades da sociologia crítica e militante e chega aos seus próprios limites. Se há, em ambos, elementos analíticos e elementos normativos, em A Sociologia numa era de revolução social, a força da análise se presta à finalidade da normatividade, ao passo que em A natureza sociológica da Sociologia é a análise que subordina toda prescrição, que a desencanta e a inviabiliza, cerrando-se no apontamento dos limites. Tudo se passa como se o ponto de chegada A natureza sociológica da Sociologia, a problematização, fosse o ponto de partida em A Sociologia numa era de revolução social - pois os problemas eram vislumbrados como passíveis de solução.

Acordando-se com Octavio Ianni, que exista "uma sociologia do cientista social no conjunto da obra de Florestan Fernandes"454, pode-se afirmar nessa obra tais reflexões se cristalizem como tal, na medida em que o cientista social e a Sociologia se tornam efetivamente objetos da análise. O pressuposto em jogo numa análise sociológica da Sociologia é que ela perca o protagonismo enquanto sujeito das transformações e ganhe

\footnotetext{
${ }^{451}$ A natureza sociológica da Sociologia, p. 66.

${ }^{452} \mathrm{O}$ escopo desse trabalho não contempla a discussão com relação à natureza histórica ou sociológica do tipo de tratamento recebido pela Sociologia. Vale ressaltar, contudo, que as aproximações e distanciamentos de Florestan Fernandes à História e à Sociologia consistem em matéria fértil para estudo dedicado às difíceis zonas fronteiriças disciplinares, que, insatisfeito com o âmbito exclusivamente teórico do assunto, pudesse escandir as imbricações entre elas, as transformações dos equacionamentos e a dinâmica imposta pela conjuntura política, pois não parece casual que a aproximação à História, incida num contexto em que urge a apreensão dos sentidos múltiplos possíveis ao presente, em que a aposta política seja menos nas estruturas que tão bem a sociologia explica. Carlos Águedo Nagel Paiva, seria talvez bom ponto de partida para o desenvolvimento desse estudo pois discute esse aspecto, chegando mesmo a afirmar que o título ideal da obra seria: A (contra)-revolução burguesa no Brasil: um ensaio de interpretação histórica.

${ }^{453}$ Metrópole e cultura, p. 251.

454 "Introdução", p. 30.
} 
relevo enquanto objeto para o sujeito que a analisa. Se esse declínio já foi enunciado em 1970, é, contudo, nessa reflexão que se torna definidor do modo de conceber sociológica e historicamente a Sociologia. Por essa razão - e não apenas por generalizar conclusões do âmbito pessoal e nacional em termos de uma contra-revolução burguesa, para o plano do capitalismo monopolista - A natureza sociológica da Sociologia é texto tributário do exercício de revisitação crítica do passado. Nele encontram-se duas condições básicas para a redução do métier a objeto: a dessacralização do intelectual, pois foi "quando o intelectual começou a descer de seu trono que sua história pôde se tornar uma história sem majestade" 455; e a segregação do analista com relação à sua identidade como cientista, pois tomar a própria prática como objeto implica em transformar parte de si em objeto também - ambas intensificadas pela desobediência civil na instituição. A costumeira complexidade, grande extensão de texto e domínio de referenciais teóricos habitam seus apontamentos de aula. Por conta disso, nossa exposição não pode ser mais que uma aproximação breve, orientada pela pertinência a desenvolvimentos futuros da reflexão.

Ao conceber os rumos históricos inscritos na revolução burguesa em oposição à revolução socialista, Florestan Fernandes delineia a situação da ciência nos quadros do capitalismo monopolista e do "socialismo de acumulação". ${ }^{456}$ A precípua diferença entre revolução burguesa e socialista consiste nas progressivas vinculações políticas definidoras da relação entre a classe social e a ordem que ela instaura. Enquanto a burguesia passa de revolucionária a reacionária, conduzindo sua revolução à contra-revolução; o proletariado seguiria um caminho inverso, pois "o desaparecimento da apropriação privada dos meios de produção" elimina "a coalescência de estratos privilegiados" e com ela, o motivo que leva “uma classe a ser 'revolucionária', em uma época histórica; 'dominante', em outra; e 'contrarevolucionária', em seguida." ${ }^{457}$ Por ser um processo permanentemente revolucionário, inclusive com relação a si mesmo - na medida em que deve se superar para chegar ao objetivo final, o comunismo - a ciência, no percurso socialista, não estagna, mas acompanha o movimento de permanente superação com relação à ordem inicialmente instaurada. Inúmeras seriam as conseqüências da adoção dessa oposição entre as revoluções - orientação que

\footnotetext{
${ }^{455}$ Jean-François Sirinelli, “Os intelectuais”, p. 240.

${ }^{456}$ Como é habitual, Florestan Fernandes, ciente dos riscos que corre, faz questão de pontuá-los. Apreender a historicidade que conforma as elaborações teóricas e a própria natureza de uma ciência, no ângulo da luta de classes, poderia sugerir vulgaridade indesejada. Daí as inúmeras advertências, como: "é cômodo falar em uma "ciência burguesa' e ceder-se a essa linguagem" que descarta os problemas efetivos. (A natureza sociológica da Sociologia, p. 20). Com efeito, "ciência proletária" e "ciência burguesa" não delimitam a problemática, pois não são as classes, mas as respectivas ordens que instauram, a referência primeira, para delimitar as condições sóciohistóricas de constituição da síntese universalizante no horizonte da ciência, tal como a concebe.

${ }^{457}$ Idem, p. 87.
} 
delimita o terreno da discussão nesse curso. Na impossibilidade de apresentá-las, cabe indicar alguns dos complexos aspectos que o autor deve enfrentar.

A autonomização da ciência no interior do processo histórico de consolidação da burguesia como classe dominante não se identifica com o processo de constituição da ciência sociológica no desenvolvimento do socialismo. Em função disso, as relações entre ciência, ideologia e utopia, das quais já havia tratado n'A Condição de Sociólogo ${ }^{458}$, em controversa mescla teórica, são retomadas. Não se pense, obviamente, numa indistinção entre esses âmbitos. A delimitação precisa, no que tange à função social, à relação com a dimensão temporal e ao contraponto com o que os mesmos elementos desempenham numa perspectiva não-socialista é matéria de longa exposição em A natureza sociológica da Sociologia. ${ }^{459}$ Mas destaque-se passo sem o qual não se compreende os desdobramentos ulteriores: o impasse entre avanço ou atraso da teoria com relação à dinâmica histórica encetada pelo movimento político - assinalada quando da exposição das reflexões no Canadá - é encaminhado pela identificação de ambos no que tange à necessária ruptura com a ordem, identificação que consiste numa via para se elaborar a identidade, na luta política, entre a intelligentsia e os movimentos de contestação da ordem. Afinal, são as transformações na natureza política da revolução que designa o que pode ser a ciência social no contexto do capitalismo e do socialismo. Há, no bojo da revolução socialista, uma redefinição da relação entre ciência $e$ civilização, pois ela não conta com a necessidade de contenção da ciência, liberta então das coerções históricas, típicas da progressiva centralização do poder no capitalismo.

O autor quer então "examinar como a alteração do status da burguesia repercute no íntimo do pensamento burguês" ${ }^{460}$ - eixo a partir do qual esquadrinha o tipo de pensamento produzido no capitalismo monopolista. A tenebrosa condição a que se vê legado o pensamento sociológico está vinculada à tendência crescentemente autoritária inscrita nas mutações desse status. Aliás, a questão da "concentração do poder" é decisiva para o autor e o insere na discussão acerca da natureza fascista do poder burguês. Para ele, o "elemento autoritário" consiste em "componente estrutural e dinâmico da preservação, do fortalecimento e da expansão do "sistema democrático capitalista'." - e é mais intenso "com a passagem para a fase de crise e de possível desmoronamento". ${ }^{461}$ Assim, a relação de dominação é normalmente, e não excepcionalmente, autoritária, na sociedade capitalista, após a burguesia

\footnotetext{
${ }^{458}$ A condição de sociólogo, p. 116-129.

${ }^{459}$ A natureza sociológica da Sociologia, p. 76-110; p. 137-145.

${ }^{460}$ Idem, p. 20.

${ }^{461}$ Apontamentos sobre a "teoria do autoritarismo", p. 8-13.
} 
ter deixado de ser revolucionária. ${ }^{462}$ Por isso, o capitalismo monopolista dispensa as clássicas funções tributadas pela tradição marxista à ciência burguesa como "ideologia", pois dispõe, ele próprio de sua "tecnologia social extracientífica" para a qual é desnecessária a explicação de mundo segundo um paradigma burguês. Não é, portanto, "na 'fetichização dos conceitos' nem na mistificação do real que reside o engajamento pró-ordem existente no pensamento sociológico liberal ou conservador ${ }^{\circledR 43}$, mas na emergência da ordem na própria forma de se produzir a ciência social.

Ela se processa através da especialização, que cumpre um papel marcadamente distinto ao da "predisposição pura para a prática de um idealismo científico" dos clássicos. A profissionalização seria a "última etapa da domesticação da ciência (no caso, a sociologia) pela tecnologia social do capitalismo monopolista e do seu sistema de poder". ${ }^{464}$ Isso porque, na produção do cientista profissional, a adesão à ordem "aparece no modelo de ordem social que vem proposto por esse pensamento". ${ }^{465}$ Tudo se passa como se o sistema adentrasse a prática científica ao tornar paradigma desta um modelo de ordem estática, sujeito a mudanças que se operam sempre no interior dessa própria ordem. Impedir a transformação - de qualquer natureza que se dirija contra a ordem - e garantir a existência ad infinitum do capitalismo parece ser a função da burguesia e do modelo de sociedade oferecido pela "nova sociologia da ordem".

Por conseqüência, elimina-se da concepção de ordem que preside o pensamento sociológico, a História - a sociologia "sob o capitalismo monopolista maduro, repele todo historicismo, extirpa a historicidade na interpretação do concreto e ignora as relações recíprocas entre estrutura e história" - e com ela a própria luta de classes como problema político, uma vez que na "sociedade de classes do capitalismo monopolista madura, a dominação e o poder da burguesia perderam sua visibilidade como e enquanto tais". ${ }^{466}$ A

\footnotetext{
${ }^{462}$ Seria bem-vindo um estudo que se propusesse a investigar as nuanças dos conceitos de "autoritarismo e fascismo". Ele daria conta de assunto controverso: a "ausência" de Antonio Gramsci em Florestan Fernandes. Até onde é possível acenar aqui, além do evidente elemento "modista" na adoção teórica do italiano em fins dos anos setenta (Ver Lincoln Ferreira Secco, A recepção das idéias de Gramsci no Brasil), essa ausência se vincula ao entendimento de que a dominação burguesa seja tendencialmente fascista, e, portanto, a hegemonia prescinda de "convergências negociadas", tornando a "noção de bloco histórico tão obsoleta quanto a noção de democracia liberal", sendo o consenso "parafascista em sua forma e funcionalmente fascista em seus resultados." ( $A$ natureza sociológica da Sociologia, p. 72). Inúmeras seriam as menções de passagem, nas quais o domínio teórico de Gramsci, e a investigação de suas contribuições fazem-se presentes, traço típico de um autor cuja refuta a modas teóricas, não impede o conhecimento dos textos (evidente nas anotações que se encontram nos livros de Gramsci em sua biblioteca) e se posiciona com precisão com relação a eles.

${ }^{463}$ Idem, p. 73.

${ }^{464}$ Idem, p. 58-61.

${ }^{465}$ Idem, p. 73.

${ }^{466}$ Idem, p. 69-71.
} 
eliminação do conflito, da História e o apagamento da ordem burguesa enquanto tal conformam o quadro do capitalismo monopolista, no qual o impasse do intelectual vem a ser o mesmo da sociedade de classes - o enfrentamento de uma ordem cujo "aparato repressivo pulveriza", "deliberada e organizadamente", o "conflito de classes, a base política para a existência de qualquer oposição revolucionária consistente", e cujo ardil é fazer a contestação girar num vazio histórico. No caso do intelectual dissidente, sua inocuidade é tanto profissional, quanto política: "sua produção não repercute, naturalmente, sobre as linhas de trabalho e de florescimento da sociologia profissional", e sua "crítica não logra repercussão eficaz ao nível dos movimentos políticos" - o que faz com que nesse jogo de forças em que nada é isento, ele faça menos do que gostaria contra a ordem e muito mais do que gostaria a favor dela, desempenhando "seu papel de 'efeito demonstração', revelando o quanto uma sociedade democrática respeita a liberdade abastrata do radicalismo sociológico abstrato."

Em sua exposição, são muito evidentes os "objetos" que alimentam a reflexão sobre a natureza sociológica do pensamento. Contudo, nem sempre a sustentação teórica da própria reflexão se faz explícita. E se bosquejá-las ultrapassa nossos limites, por outro lado, o parentesco das formulações com a perspectiva de Georg Lukács em História e consciência de classe impõe uma mínima menção. A relação hierárquica estabelecida entre "sociologia da revolução" e "da dominação", bem como entre as "soluções dentro da" e as "soluções contra a ordem", parecem tributárias da noção lukaciana de limite da consciência burguesa. A "sociologia da dominação", uma vez que não precisa chegar ao fundo das explicações, desenvolve-se no interior do "paradigma da eficácia de uma dada civilização". E, por operar dentro da ordem, o limite da consciência burguesa espelha seu avanço limitado e sua perspectiva sociológica empobrecida: “o 'limite burguês' não vai ao fundo da realidade. Entretanto, isso seria necessário quando o alvo central é a dominação" e "a mudança dentro da ordem estabelecida?" outro lado da moeda, fazê-la emergir novamente, por isso, a "sociologia da revolução" tem tarefas adicionais junto à classe e à ordem que representa. Dessa maneira, a problemática que se movimenta no interior da ordem é tomada como hierarquicamente inferior também do ponto de vista da ciência, pois é indício da limitação da crítica que não ultrapassa o limite da adesão à ordem. ${ }^{469}$ Daí entender que, na "nova sociologia da ordem", o componente

\footnotetext{
${ }^{467}$ Idem, p. 62-63.

${ }^{468}$ Idem, p. 30-31.

${ }^{469}$ Ponto alto da exposição em que essa perspectiva define a abordagem é a crítica ao intelectualismo de Wright Mills e Gouldner. (Idem, p. 64 e segs.)
} 
revolucionário "intrínseco à ciência” é eliminado, e, "como o cirurgião, o sociólogo limita-se às condições imediatas que possam garantir o seu êxito 'operacional'. " ${ }^{470}$ Imagem forte que adensa o sentido de neutralidade comprometida com a ordem. A saúde do organismo para o médico equivale ao funcionamento "normal" da ordem para o sociólogo "neutro". E nenhum dos dois se empenharia em combinações diversas entre os elementos do organismo/ordem.

Ademais, a ciência não encontra em si mesma sua força motora e perdeu o controle sobre suas próprias atividades, de modo que "o sistema institucional da ciência não se autodetermina nem se auto-regula"471, mas se encontra inexoravelmente submetido ao "uso racional por forças irracionais da sociedade". ${ }^{472}$ Dessa maneira, as condições de irrealização dos intelectuais modernos e do pensamento revolucionário no capitalismo monopolista apresentam limitações e impossibilidades homólogas àquelas apresentadas em seus depoimentos, com relação à sujeição de seu grupo à dinâmica da contra-revolução burguesa.

Colocam-se em tela formulações que revelam a erosão definitiva dos ideais cristalizados na concepção de uma Sociologia Aplicada, cuja função prevista the parece então dispensável, e mesmo impossível, pois o mais genuíno esforço racional "não alimenta processos específicos de constituição, crescimento e aplicação em larga escala de uma tecnologia central ou tendencialmente científica." ${ }^{473}$ Não por acaso, a noção de que a modernidade se realize no socialismo não diz mais respeito apenas à periferia do capitalismo, mas se generaliza. Tendo em vista as condições de institucionalização, profissionalização e mercantilização do trabalho, mesmo nas sociedades "mais democráticas" do capitalismo monopolista, a ciência e os cientistas sociais estão sujeitos à cooptação e à limitação semelhantes às impostas pela (contra)revolução burguesa na periferia - sendo ainda mais profunda a "rede de aspirações" da classe média de que fazem parte. ${ }^{474}$

Passa a ser seu problema, afinar, efetivamente, a racionalidade da ciência à de uma ordem social substancialmente racional: a "impregnação burguesa da explicação científica na sociologia desembocou nesse impasse, que só pode ser superado pela ruptura total com a ordem e através da liberação do pensamento científico pelo socialismo." "775 Portanto, é “o advento de uma civilização na qual os sociólogos deixem de ser servos do poder" ${ }^{\text {"47 }}$ que

\footnotetext{
${ }^{470}$ Idem, p. 61.

${ }^{471}$ Idem, p.52-56.

472 Idem, p. 67.

${ }^{473}$ Idem, p. 25.

${ }^{474}$ A condição de sociólogo, p. 162-163.

${ }^{475}$ A natureza sociológica da Sociologia, p. 75.

${ }^{476}$ Idem, p. 44.
} 
guarda as condições de realização das promessas da modernidade, segundo as quais "seria possível conhecer, prever e agir racionalmente graças às potencialidades ilimitadas de democratização abertas pela civilização moderna". ${ }^{477}$ Nessa ordem, socialista e planificada, a dinâmica social e a científica convergem para uma racionalidade equivalente - universalista e de progressiva abertura - em oposição à mercantilização, à ausência de autonomia e aos fins extra-científicos e irracionais que, característicos do capitalismo monopolista, emergem no seio da ciência e inviabilizam a racionalidade originária, que a define na concepção de Florestan Fernandes.

Daí, que legue o ressurgimento vigoroso da sociologia clássica à expectativa futura, esteio no qual ela se emanciparia da destinação melancólica que o desenvolvimento capitalista lhe impôs - afinal, o socialismo não deve dispensar a Sociologia, por sua origem histórica burguesa. Ao contrário, se considera que "é só sob o socialismo que a revolução pela ciência alcança plenitude e pode completar-se - porque ele elimina o controle irracional de sua racionalidade" ${ }^{\text {"47 }}$, a autonomia e o compromisso intelectuais formulados paradigmaticamente em um livro como A Sociologia numa era de revolução social encontrariam condições de realização numa ordem socialista planificada, na qual, "o querer algo socialmente" adentraria o "ver algo socialmente", como "padrão pedagógico normal". A crítica social seria “componente estrutural e dinâmico da reação societária às propostas de mudança e à orientação da mudança", de modo a cobrar da ciência a expansão de sua "imaginação sociológica". 479

No interior das concepções apresentadas, vistas na esteira da reflexão encetada nas memórias do autor, pode-se entender que a violação da ordem torna-se o pressuposto para o exercício de uma atividade intelectual legítima. A subversão da ordem pela recusa à autonomia científica ascética politicamente e a violação da estrita divisão institucional das competências, no trabalho do pensamento não especializado - que permitem priorizar a temática política e a crítica da própria teoria - delimitam sua produção na PUC-SP e

\footnotetext{
${ }^{477}$ Idem, p. 36.

${ }^{478}$ Idem, p. 101.

${ }^{479}$ Idem, p. 144. Seria instigante esboçar o papel da reflexão sobre a sociologia, como tomada de posição com relação a acalorados debates em voga, acerca do chamado "socialismo real". A ciência e a liberdade nos países socialistas, o totalitarismo de esquerda que faz de comunismo e socialismo, irmãos siameses; a relação entre Estado, partido e representação num processo revolucionário - são questões que marcam seções do curso, nas quais a reflexão sobre a sociologia parece mero pretexto para tangenciar tais debates. A necessidade proeminente parece ser a de afirmar que a sociologia não terá o mesmo desenvolvimento que teve em seus vínculos com a consolidação da ordem burguesa, e manter sua adesão ao paradigma científico racionalista; no mesmo passo em que defende que o socialismo não desemboca inexoravelmente na impossibilidade de realização do 'socialismo democrático' e do 'comunismo' - perspectiva entendida como ardil do próprio capitalismo monopolista. Ver, especialmente, as últimas aulas do curso, p. 96-145.
} 
encontram revérbero em suas reflexões. A inserção institucional está subordinada à possibilidade de sua própria transgressão.

É imperativo que se retorne a um dos caminhos percorridos pela reflexão, que assinalava os vínculos de classe em jogo na inserção institucional - e se questione: a subversão delineada garante a negação das relações de classe que ali se tecem? É sempre elucidativo que se vislumbre as palavras dirigidas a platéia constituída por uma cidadania ilustrada, envolvida, tal qual a instituição que preside o evento, a SBPC, naquele prestígio intelectual tão característico do contexto, e tão refutado por Florestan Fernandes, que assegura que o intelectual deva "conquistar novos papéis e, muitos deles, só parcialmente são papéis intelectuais" - pois:

"Quanto mais eles se vincularem à realidade pela ótica institucional (dos assim chamados papéis intelectuais legítimos...) pela ótica de classes (dos assim chamados papéis radicais de um setor desenraizado das classes médias...) ou pela ótica da estabilidade da ordem (dos assim chamados papéis sociais que os intelectuais desempenham como membros natos das elites culturais... a posição estratégica que eles ocupam na informação dos policy makers ...), menos eles verão claramente o que lhes compete fazer. Para falar com franqueza, é preciso superar o limite histórico que foi escrupulosamente respeitado nas décadas de 40,50 e 60 (...), 480

Entretanto, essa superação só poderia ser equacionada se a problemática da delimitação dos opostos - ciência sob coerção e em liberação vinculadas às progressões políticas opostas dos processos revolucionários em desenvolvimento - fosse deslocada para a história in flux e se propusesse a equacionar a emergência, não da ordem mas da revolução, na atividade do intelectual. Contudo, isso depende de fatores alheios à disposição inelutável do autor à autocrítica. $\mathrm{O}$ deslocamento à história in flux não ocorreria sem a emergência da própria história no terreno político estático forjado pelo regime militar. Eis o tema da seção seguinte.

\footnotetext{
480 “Tarefas dos intelectuais na revolução democrática”, p. 52.
} 


\section{Da gaiola de ouro à vida pública: aproximação da conjuntura política.}

Em 1968, a repressão às greves de Contagem e Osasco havia estabelecido o silêncio político dos trabalhadores. Um grito estridente, dez anos depois, viria a colocá-los novamente na cena política. O período está marcado pela emergência de movimentos sociais, e como um todo o meio intelectual se vê sacudido por eles. Os diversos episódios que reconstituem esses anos convergem para a problemática central, que absorve Florestan Fernandes: o significado daquele grito para o desafio ao controle pelo alto do processo de abertura e para a realização da modernidade nacional - faces de um mesmo projeto de revolução democrática e socialista. O tom melancólico dos seus escritos cede passo a novo fôlego, no qual aflora o traço aguerrido na defesa das posições tomadas - como expressão do envolvimento incansável do autor, tanto com a contestação social quanto com as oscilações relativas a um regime que toma para si o controle de seu próprio desfecho. À ensurdecedora, desconcertante e determinante voz dos silenciados nos rumos da reflexão do autor, dedica-se essa seção.

Há um componente trágico que conforma a condição da "sociologia crítica" nos quadros do capitalismo monopolista. Os intelectuais "não podem competir" com "os representantes da sociologia profissional, que monopolizam a direção do desenvolvimento da sociologia como ciência”. E sequer podem demolir os muros de seu isolamento, que cerceiam "qualquer aspiração concreta de polarizarem seus papéis como se fossem intelectuais orgânicos da contestação". Celebram, dessa maneira, um "curioso ritual de trocas compensatórias", pois a sociedade "detestada oferece o maior conforto material a seus sociólogos indomáveis. Estes, por sua vez, não conspurcam o templo do saber. Refugiam-se no radicalismo sociológico abstrato e bicam, como vingança, a mão que os alimenta." ${ }^{481}$ Com efeito, essa vingança parece expressar figuradamente a congruência entre a transgressão da ordem, assinalada para a atividade na PUC-SP, e outras atividades do sociólogo, dentre as quais, destaca-se, sua atuação como editor.

Em sua estadia no exterior, a atividade como editor lhe atrai pela possibilidade de complementação da renda; expectativa, contudo, frustrada. ${ }^{482}$ Ao retornar do Canadá, junto com José de Souza Martins e Jaime Pinsky, será artífice de duas revistas, Debate e Crítica e Contexto - cujo alcance editorial não se iguala a congêneres como Opinião e Movimento. Sua

\footnotetext{
${ }^{481}$ A natureza sociológica da Sociologia, p. 63.

482 "Florestan Fernandes por ele mesmo", p. 149.
} 
atuação editorial mais significativa, contudo, será a coordenação da Coleção Grandes Cientistas Sociais da Editora Ática e da Coleção Pensamento Socialista da Editora Hucitec, dividida em três séries, a saber: Clássicos; Linha de Frente; Debate Contemporâneo.

Como quer Paulo Henrique Martinez, as coleções expressam a "preocupação em disponibilizar determinadas obras e autores", relativamente "exteriores ao universo das ciências sociais recorrente em faculdades e universidades brasileiras" ${ }^{483}$ - diletos, contudo, ao universo da cultura de esquerda com filiação marxista. Com efeito, "Grandes Cientistas Sociais", editada entre 1978 e 1990, cujo objetivo são as "salas de aula" e os "professores" do ensino em nível médio e superior conta com nomes como "Bukhárin, Che Guevara, Engels, Fidel Castro, Ho Chi Minh, José Carlos Mariátegui, Lênin, Mao Tsé-tung, Proudhon, Reclus, Stálin e Trotsky" - "notórios ativistas" que compõem aproximadamente um terço dos volumes. ${ }^{484} \mathrm{~A}$ presença significativa desses autores poderia ser tributada à "conexão existente entre teoria e prática, no âmbito do Materialismo Histórico e da Economia Política". 485 Contudo, como assinala Paulo Henrique Martinez essa razão é insuficiente para iluminar a proposta em jogo. Decerto, esse aspecto pode justificar a presença daqueles autores. Não desvela, contudo, a dinâmica intelectual e política no cerne da concepção da Coleção. A possível justificativa não deve se confundir com motivos subterrâneos. Mais que aventar a relação entre "teoria e prática", a seleção traz a lume "a viabilidade de determinado papel dos intelectuais e dos dirigentes políticos, em diferentes contextos sociais e nacionais: Rússia, China, Vietnã, Franca, Cuba, Alemanha, Brasil, Peru", ressaltando a "combinação da 'fermentação teórica' criativa e do ativismo político que os intelectuais encontram e podem alimentar quando inseridos em enfrentamentos sociais e políticos das classes trabalhadoras." 486

A Coleção equivaleria a seus artigos reflexivos produzidos no Canadá e aos depoimentos autobiográficos, na medida em que propõe e repõe a problemática dos vínculos com a luta política e a produção teórica nos quadros de contextos históricos revolucionários, referenciais para o Brasil e seus intelectuais. Assim, é possível cogitar que a "presença de tais autores" quer propor um engajamento "aos intelectuais no Brasil e às atividades que estes deveriam desenvolver nos movimentos sociais e nos partidos políticos reformistas e

\footnotetext{
${ }^{483}$ Paulo H. Martinez. "Prefácio". In.: Florestan Fernandes. Pensamento e ação: o PT e os rumos do socialismo. São Paulo: Globo, 2a ed., 2006, p. 13.

484 Idem.

485 Idem, p. 13-14.

486 Idem.
} 
revolucionários." 487 Evidente que nessa seleção manifesta-se aquele desvio da finalidade institucional oficial, reconhecida e sustentada pela ordem, subordinado aos fins da crítica social, ou seja, a desobediência civil, tal como esboçada anteriormente.

Essa perspectiva pode ser endossada ainda, se atentarmos para o estabelecimento de paralelismos e aproximações de contextos históricos (contra)revolucionários às possibilidades em aberto no processo político nacional, como procedimento recorrente em inúmeros textos. Analogias entre a Rússia czarista da pré-revolução socialista e a América Latina podem ser encontradas pelo menos desde sua estadia no Canadá - sinalizando que seus estudos autônomos e solitários acerca das revoluções chinesa, cubana e russa, concentradas naquele período, prestam-se ao objetivo de apreender a América Latina e o Brasil, em suas possíveis condições revolucionárias, e talvez, à oculta intenção teórica de apreender casos clássicos e não clássicos de revolução contra a ordem. A freqüência, o aprofundamento e a ampliação desses "elucidativos paralelos"488 têm máxima expressão nos textos comemorativos do centenário de Marx, cujo contexto histórico original sofre sensível "abrasileiramento". ${ }^{489}$ Seja para tornar a apresentação de sua tomada de posição mais acessível aos diversos públicos, em que a ilustração histórica pode ser recurso político-pedagógico auxiliar, ou para esboçar uma teorização de revoluções avessas ao "modelo clássico", o paralelismo histórico como fonte de reflexão torna-se constante. Pode, portanto, estar presente na seleção desses "Grandes Cientistas Sociais" de revoluções.

Florestan Fernandes, ele próprio, empenha-se em atuação francamente inspirada num dos perfis apresentados pela coleção: Lênin. Esse publicista, identificado por Paulo Silveira, do qual a dimensão de editor é parte constituinte, para Paulo H. Martinez ${ }^{490}$, pode ser apreendido segundo noções extraídas da "Introdução" do próprio autor - que, se fora concebida em 1972, ganha terreno para expressão histórica a partir de 1978. Esse ano pode, inclusive, ser considerado um marco na expressão pública de sua radicalização e aproximação com o universo da cultura marxista de esquerda. ${ }^{491}$ Sua "orgulhosa" ${ }^{\text {"492 }}$ leitura de Lenin ecoa entre os pares, através de três publicações: os prefácios de Que Fazer? e O Estado e a

\footnotetext{
${ }^{487}$ Idem.

488 "Sociologia, modernização autônoma e revolução social”, p. 156.

${ }^{489}$ Evidente inclusive no parentesco dos termos que emprega para as situações revolucionárias e o contexto nacional. Ver, especialmente, "Marx: revolução e luta de classes". In.: Em busca do socialismo: últimos textos \& outros textos. São Paulo: Xamã, 1995, p. 58.

490 "Um publicista revolucionário"; "Prefácio", p. 11.

${ }^{491}$ Haroldo. C. Sereza, Florestan: a inteligência militante, p. 162.

${ }^{492}$ Em feliz expressão de Haroldo C. Sereza (Idem, p. 161). O "orgulho" vem selado pelo reconhecimento da leitura completa da obra de Lênin na edição francesa - que tive o prazer de manusear quando visitei sua biblioteca, acolhida pela Universidade Federal São Carlos.
} 
Revolução - em "Pensamento Socialista", da Hucitec; e sua Introdução ao volume quinto da Coleção Grandes Cientistas Sociais da Ática, dedicado a Lênin. ${ }^{493}$ Às alusões constantes a Florestan Fernandes como editor de Lênin, fomentadas por essas publicações, adicione-se que ele "costumava dizer e escrever que era marxista-leninista"494 - auto-representação densa de significações, tanto para compreensão de suas posições políticas quanto de suas intervenções como intelectual, cristalizadas na adoção do perfil publicista, papel que, aliás, supõe ser o mais dileto de Lênin. 495

Paulo Silveira traça o retrato desse perfil em três linhas: um "conhecimento históricoestrutural" do modo de inserção nacional no capitalismo mundial; a tomada de posição política marcada pela "intransigência em relação às diversas formas de compromisso, de conciliação e de cooptação"; e ainda, uma "concepção de história que situa a luta de classes" no "campo das possibilidades do devir histórico". ${ }^{496}$ A precisão das indicações permite associá-las, uma a uma, respectivamente, ao que Florestan Fernandes concebe em Lênin, como: interpretação da história; análise da conjuntura política; e marxismo-leninismo. Indissociáveis, esses traços conformam uma prática analítica e uma intervenção pública, cujo sentido político é oferecido pelas novas condições em que se encontra o cenário político nacional.

Florestan Fernandes salienta a imbricação entre o intérprete da História e o condutor da luta política, em Lênin, pois é como "intérprete da história em processo" que apreende o sentido da luta política presente. A precisa interpretação global confere sentido à luta particular na qual se empenha, enquanto sujeito histórico e político, o próprio analista assegurando a difícil combinação entre flexibilidade dos meios e intransigência dos fins. ${ }^{497} \mathrm{~A}$ flexibilidade defende o propósito revolucionário do revolucionarismo cômodo, que o torna equivalente ao reformismo, na medida em que esvazia de sentido a ação política; e, pari passu, a intransigência dos fins defende a flexibilidade do perigo mortal da conciliação, ameaça permanente que converte as intenções revolucionárias em práticas reformistas. A referência global é âncora para a ação política particular - de modo que a análise, em perspectiva interpretativa histórica, demarca o campo de prováveis para o presente em curso,

\footnotetext{
${ }^{493}$ Além disso, "A atualidade de Lênin" é tema para o jornal Leia Livros. Os vínculos com Lênin são ratificados por "Lênin e o Socialismo", para Voz da unidade, em 21/01/1984 - em clara alusão às seis décadas de morte do revolucionário russo. (Reunidos em Brasil: em compasso de espera).

${ }^{494}$ Segundo Antonio Candido "Um militante incansável". In.: Paulo H. Martinez. (org.) Florestan ou o sentido das coisas, p. 44.

495 "Introdução", p. 13-14.

${ }^{496}$ Paulo Silveira, "Um publicista revolucionário", p. 289.

497 "Introdução", p. 15.
} 
esclarecendo os rumos futuros possíveis, segundo o patamar político em que se encontra a luta de classes. E ainda, para o autor, intérprete da História e analista da conjuntura são faces do mesmo homem político, amálgama que se exprime em "Que fazer?, como obra de síntese e de superação das experiências políticas acumuladas durante o período de formação" e consiste na "face política das descobertas históricas e econômicas contidas em $O$ desenvolvimento do capitalismo na Rússia". 498

Dessa maneira, os contornos da físionomia do publicista não são traçados sem a perspectiva que define o retrato: o "marxismo-leninismo" - concebido como apreensão da luta de classes, enquanto relações de poder, ou seja, em seu âmbito especificamente político. Essa angulação da análise conforma a problemática: "sob as condições mais ou menos paralisadoras da democracia burguesa, como dar ao proletariado" a "capacidade de converter seu poder potencial em poder real?" 499 Atuar sobre e pensar a passagem do poder potencial para o poder efetivo da maioria explorada exigia um aproveitamento racionalizado do mínimo espaço político disponível, condicionado e condicionante da flexibilidade dos meios e da intransigência do fim. Por isso, Lênin "ignorou o peso paralisante da existência ou inexistência de condições objetivas que permitissem a revolução proletária", deslocando "em várias direções o aproveitamento revolucionário das condições objetivas existentes" e enfatizando o "controle político das condições subjetivas" - que seriam "mais suscetíveis de tratamento político deliberado, segundo manipulações estratégicas e táticas". ${ }^{500}$ É evidente que o emaranhado político, histórico e teórico a que conduz essa asserção, se não pode ser explorado aqui, deve ser mencionado: remete-se às vicissitudes típicas da relação entre massa e vanguarda - que, uma vez entendidas do ângulo da unidade entre prática e teoria colocam o problema da objetividade do conhecimento, pois esta não é haurida estritamente, nem no campo científico, nem no político, porém na relação entre ambos que se tece no processo histórico em curso. A pedra de toque consiste em conceber a subjetividade histórica da classe, que é a protagonista da revolução encetada, no centro da validade do conhecimento. Vimos como isso é elaborado. Quando se trata de um período pretérito e bem sucedido, é possível afirmar que a previsão do intérprete da história "se for politicamente verdadeira, será, por sua vez confirmada pela aceitação das massas". ${ }^{501}$ Concebê-lo, contudo, no presente em que ele mesmo, analista, é sujeito histórico e que, ademais, não oferece referenciais de

\footnotetext{
${ }^{498}$ Idem.

${ }^{499}$ Idem, p. 17.

${ }^{500}$ Idem, p. 19.

${ }^{501}$ Idem, p. 44.
} 
certeza, é tarefa sem precedentes. É sensível, como observa Gabriel Cohn, que nas conclusões das prospecções sociológicas d'A revolução burguesa no Brasil, o autor esquadrinha os desdobramentos possíveis da modernização acelerada, que parecem antever a própria emergência das greves do $\mathrm{ABC}$ e a formação do próprio PT. ${ }^{502}$ Conseguiria a prospecção sociológica antever as orientações políticas do "novo sindicalismo", contudo? Consistiria essa antevisão em efetiva unidade entre teoria e prática no seio do marxismo?

Diante dessas dificuldades, a reflexão não se esquiva. Ao contrário, a prática analítica, que se empenha pela precisa apreensão da conjuntura política, intimamente imbricada com uma interpretação da História, e tendo por perspectiva a luta de classes como relação de poder - cuja expressão máxima, enquanto intervenção pública consiste numa "forma de atuação deliberada" que não "deixava escapar oportunidades de comunicação"503 _ delineia o publicista Florestan Fernandes. A revolução burguesa no Brasil, ensaio concluído em 1974, à luz do novo contexto, passa a ser tomada como interpretação da história, sem a qual a análise da conjuntura política careceria de sentido. O intérprete da história a concebe nos termos da bifurcação entre duas tendências - revolução e contra-revolução - definidoras da crise de civilização, e cabe ao analista da conjuntura encontrar as tendências de uma e de outra, de modo a oferecer insumos aos "mínimos políticos", que coloquem a maioria explorada no poder. É válido notar que está em jogo uma espécie de dupla historicidade das questões trazidas pela apresentação de Lênin - evidente pelo vínculo com o contexto político e reflexivo fomentado pelo golpe militar de 1964, e pela pertinência de sua abordagem aos problemas do oposicionismo em 1978. Dupla historicidade expressiva do próprio processo político nacional, o qual conjuga problemáticas de um momento e outro e, por conseguinte, dos dilemas enfrentados pela resistência à ditadura militar, com orientação de esquerda. A ênfase para pensar o político, com a urgência de se desvencilhar do limite que a própria esquerda se coloca quando opta pela maturidade das "condições objetivas" para a "revolução" é um apelo ao presente, imbricado com o exame crítico do que passa ser considerado erros pretéritos, com o esfacelamento tanto da luta armada quanto do Partido Comunista, e com as ambigüidades do próprio regime.

Entretanto, se quando "forças antiburguesas ganham saliência, a história prevalece e o elemento democrático se expande, amparado nos interesses e situações de classe da

\footnotetext{
502 "Florestan Fernandes - A revolução burguesa no Brasil”, p. 407.

${ }^{503}$ Paulo H. Martinez, "Prefácio", p. 11.
} 
maioria" ${ }^{504}$, e quando a estrutura se manifesta "o que é mais profundo vem à tona e revela a face burguesa da imposição da autoridade" - o publicista não afloraria, sem que a própria história emergisse no cenário político, rompendo sufocantes estruturas formadoras do contexto nacional. Daí que a ascensão dos movimentos sociais urbanos, com destaque para as greves do $\mathrm{ABC}$, imprima novos sentidos à sua produção pretérita e cobre novos rumos à sua produção presente, constituindo a seiva bruta da qual extrai a matéria-prima para sua atuação pública.

Indubitavelmente, dizer que a história orienta sua reflexão numa determinada direção não significa que o problema trazido por ela já não fizesse parte das preocupações do autor. Ao contrário, e aí reside a significação especial do "novo sindicalismo" no percurso da obra de Florestan Fernandes. Tanto a perseguição obstinada das condições de realização da modernidade, que caracteriza a fração de sua obra produzida no circuito universitário, quanto a virada em busca das forças políticas alternativas à ordem burguesa, característica do período a que nos dedicamos, parecem ter encontrado o agente que buscavam. ${ }^{505}$ Por isso, pode-se afirmar que há um amálgama entre o deslocamento da reflexão para o presente in flux, a convocação da história e antigas preocupações sociológicas de Florestan Fernandes, tomadas agora numa perspectiva preponderantemente política. Daí um entusiasmo crítico tão saliente com a emergência do "novo sindicalismo" - é ele que lhe desafia a analisar as relações de poder nas lutas de classes e a emergência do inédito histórico. Nova angulação, com teor político, notada inclusive por Gabriel Cohn, que, se caracteriza Florestan Fernandes como um pensador que perscruta o "ângulo específico pelo qual uma determinada sociedade possa ser pensada sociologicamente", assegura que nesse momento, “a reflexão sociológica se mistura mais fortemente com a reflexão de caráter mais propriamente político." 506 José de Souza Martins constata a passagem desse enfoque para o tipo de intervenção pública de Florestan

\footnotetext{
${ }^{504}$ Apontamentos sobre a "teoria do autoritarismo", p. 14.

${ }^{505}$ Recorde-se, como capítulo das perseguições sociológicas de Florestan Fernandes, sua preocupação com a formação das classes sociais, também tributária da precariedade definidora da floração moderna na periferia. A relevância desse tema para o oposicionismo intelectual fica paradigmaticamente representada em Seminário realizado em dezembro de 1971, no México - em que, Florestan Fernandes, Nicos Poulantzas, Alain Touraine, Fernando Henrique Cardoso, Francisco Weffort, entre outros, reúnem-se para debater o tema: "As classes sociais na América Latina. Problemas de conceituação". Dentre as várias edições que o evento recebeu, destaca-se a que reproduz sua estrutura com três partes, dedicada a cada autor principal e seus comentaristas: Raul Benitez Zenteno (org.) As classes sociais na América Latina. Problemas de conceituação. Rio de Janeiro: Paz e Terra, 1977. O texto de Florestan Fernandes seria o segundo capítulo do primeiro livro publicado quando de seu retorno ao Brasil: "As classes sociais na América Latina". In.: Capitalismo dependente e classes sociais na América Latina.

506 "Padrões e dilemas: o pensamento de Florestan Fernandes", p. 136-137.
} 
Fernandes, esmerada então na convicção de que "o meio da transformação se deslocara da educação para a política."507

Resulta daí a análise minuciosa do que designa por conciliação. Noção que povoa os escritos, expressão teórica de uma "perseverança política e ideológica, algumas vezes confundida com intransigente idealismo" ${ }^{, 08}$, conciliação aparece no coração dos entrelaçamentos esboçados, entre a interpretação da história e a conjuntura política, entre as preocupações sociológicas de longa data e o entusiasmo crítico no presente.

Florestan Fernandes é um crítico mordaz da ditadura militar, enquanto cristalização do modelo de desenvolvimento capitalista autocrático, típico da periferia do sistema e representativo da concentração de poder na etapa monopolista do capitalismo. Por isso, recusa-se com virulência a pensar e agir "como se o essencial fosse só acabar com a ditadura" - ao contrário, "pela lógica dos fatos, o essencial só pode vir depois" de uma revolução democrática que incorpore "o povo à nação", e desmascare as "conquistas democráticas da ótica burguesa", que "surgem como são, meras panacéias ou pontos de partida de transformações mais profundas." ${ }^{509}$ Abdicar de uma perspectiva que tenha por fim a revolução democrática implica aceitar a reposição do circuito fechado - no qual a igualdade é privilégio dos mais iguais - atualizado sob a forma de "democracia de cooptação", em que os novos setores sociais são absorvidos naquele círculo estreito que segrega o povo da nação: “observando-se esse 'período de transição', que mal se inicia, vemos que ele é típico”, refezse "todas as vezes que as elites dos estamentos ou das classes dominantes se viram postas diante da história viva" e "isolaram o Povo". Por isso, "em vez de entoarmos loas a um suposto 'espírito' de conciliação e de reforma, cabe-nos romper com o egoísmo exorbitante, que nos levou ao beco sem saída do capitalismo dependente". ${ }^{510} \mathrm{O}$ antídoto consiste na ruptura com padrão segundo o qual a segregação se reproduz, e impossibilita a realização da democracia - o que equivale à revolução contra a ordem, uma vez que no Brasil a crise do capitalismo e a necessidade da contra-revolução permanente "grassariam sob o manto de um fenômeno recorrente nas dinâmicas institucionais e nas práticas de dominação e de controle social, a conciliação", através da renovação de "acordos firmados no tope das hierarquias sociais e políticas". 511

\footnotetext{
507 “Prefácio", p. 15.

${ }^{508}$ Idem, p. 18.

${ }^{509}$ Brasil: em compasso de espera, p. 58.

${ }^{510}$ Idem, p. 2

${ }^{511}$ Paulo H. Martinez, "Prefácio”, p. 16.
} 
Na preocupação com a conciliação estão entrelaçados alguns fatores. Incidindo sobre "perigos presentes", retoma preocupações do sociólogo, pois, como se sabe, democracia, com nuances, marcadas pelas transformações de conjunto em seu pensamento, é tema nunca sai de sua mira. ${ }^{512}$ Além disso, remontando a um padrão de dominação e desenvolvimento, sustenta a concepção de democracia defendida num equacionamento sociológico - aspecto que distingue sua elaboração, nos debates em torno da abertura política, de perspectivas mais frágeis teoricamente. ${ }^{513}$ Ademais, exprime, na contramão do reconhecido abandono da centralidade da revolução pela adoção da "questão democrática", que em seu esquema, a revolução é pressuposto da democracia, pois "a sociedade de classes engendrada pelo capitalismo na periferia é incompatível com a universalidade dos direitos humanos". ${ }^{514}$

É preciso reconhecer que, se, por um lado, a análise que tem fulcro nessa noção pode ser tomada como "puro esquerdismo" 515 , não é irrelevante o lastro histórico que lhe dá sustentação. O regime autoritário, em meados dos setenta, define-se por sua ambivalência, que se não é favorável à precisão de diagnósticos, acaba por ratificar o esquema interpretativo segundo o qual a "abertura democrática não é só um armadilha do SISTEMA. Ela contém o avanço que o poder burguês pode realizar aqui e agora sem arriscar-se a um sério e irreparável deslocamento político." ${ }^{516}$ Cabe lembrar que o autor, com a dramática lucidez que lhe é habitual, reconhece que esse posicionamento possa levar a um revolucionarismo, do tipo "tudo ou nada". Por isso, sua insistência em que a conquista democrática, institucional e constitucional, seja encarada como uma luta válida, sem a qual o "revolucionarismo" abriria a porta dos fundos para o "comodismo". Entretanto, que seja válida enquanto momento de partida; jamais, como um ponto de chegada. Essa consciência se expressa na gradação pensada para a democracia enquanto abertura política, econômica e social, cujo ponto máximo coincidiria como o socialismo - são oriundas daí inúmeras expressões como democracia restrita, democracia de participação ampliada, bem como diversos empregos de "democracia burguesa" e "socialismo democrático", que, banhados de ironia, pululam nos textos do publicista. Assim, o reconhecimento de que as "classes trabalhadoras não possuem" as "condições objetivas e subjetivas para provocar uma mobilização revolucionária da massa

\footnotetext{
${ }^{512}$ Gabriel Cohn, “Apresentação”, p. 5; Maria Arminda do Nascimento Arruda, Metrópole e cultura, p. 246.

${ }^{513}$ Como a de Carlos Nelson Coutinho, por exemplo, cujo eixo central é a democracia "como valor". (A democracia como valor universal e outros ensaios. Rio de Janeiro: Salamandra, 1984. O texto aludido é de 1979).

514 "Resposta às intervenções: um ensaio de interpretação sociológica crítica". In.: Encontros com a Civilização Brasileira, n. 4. Rio de Janeiro, outubro, 1978, p. 201-202.

${ }^{515}$ Paulo H. Martinez, "Prefácio", p. 18.

${ }^{516}$ Brasil: em compasso de espera, p. 15.
} 
pobre da população contra a ordem existente", não o impede de postular: "parece evidente que se acham em suas mãos" o "grau de alargamento democrático da ordem burguesa". Em remetência inequívoca a Lênin de Que fazer?, assegura que, em períodos nos quais a própria contra-revolução se encontra em crise, como em 1979, quando, sequer o milagre a legitima mais, é freqüente a pressão por "alianças com a burguesia desmoralizada, egressa da derrota tácita ou contundente da contra-revolução suplantada" - e, por isso, faz-se ainda mais necessário "introduzir conteúdo político socialista a essa pressão radical de massa”, pois ceder àquelas pressões implica em "sufocar os fluxos nascentes da revolução". 517

É dispensável nesse trabalho reconstituir as idas e vindas do famigerado processo político - a oposição emerge em eleições em 1974, o regime responde com o Pacote de Abril em 1977, a oposição ganha e o regime também, com a Anistia de 1979, o regime perde e a oposição também, com o pluripartidarismo - e as controvérsias acerca das perdas e danos, referentes a um lado e a outro da luta política. A dinâmica da própria distensão/abertura, caracterizada pela lentidão e incerteza, cujos avanços e recuos dão mote para a insolúvel questão, ainda hodierna, acerca dos papéis de controle e condução do processo, acaba por ratificar o diagnóstico de Florestan Fernandes.

Coevamente, momento no qual decidir acerca do tema era estabelecer estratégias para a ação política, ele não se furtou a intervir no debate. Desempenhou, inclusive, o difícil papel de levar seus pares a "questionamentos básicos"518 - atuação possível em razão de sua militância solitária e posicionamentos singularmente radicais. Suas intervenções expunham a limitação de outras concepções, colocando problemáticas e desafiando o meio a enriquecer suas perspectivas, pois se via diante do imperativo de respondê-lo - como se evidencia na declaração de Gérard Lebrun: o "o discurso que ele enuncia" não é "sedutor", é "certas vezes até desagradável para a opinião superficialmente esclarecida. - De qual democracia, exatamente, você está falando?, pergunta ele". ${ }^{519}$ De maneira que, aos "olhos de um observador estrangeiro, a análise de Florestan Fernandes" parece "mais convincente do que muitos discursos emolientes e abstratos sobre o nascimento ou renascimento da democracia". ${ }^{520}$ Com efeito, a identificação, na derrota de 1964, de uma prática formulada a partir de paralelismos históricos etapistas e imediatos, que previa a realização da "revolução

\footnotetext{
${ }^{517}$ Idem, p. 10. Mencione-se que essa temática não se esgota sem consideração detida de texto pouco comentado, Partidos políticos e movimento socialista (São Paulo: Hucitec, 1980), no qual procura desenvolver implicações organizacionais, em plano legal e ilegal, de seus posicionamentos.

${ }^{518}$ Octavio Ianni, "Introdução", p. 12.

519 "O Brasil de Florestan Fernandes", p. 263.

${ }^{520}$ Idem, p. 273.
} 
burguesa" na periferia idêntica ao centro, resulta numa acuidade severa, do autor no trato dos temas da democracia e da revolução. Nas palavras de Gérard Lebrun, a "democracia formal, na Europa, certamente teve mais sorte do que pensava Marx", ela "foi mais astuta do que ele previa", contudo, aqui "ela se vê impotente para desempenhar um papel comparável" - e, trágica e ironicamente talvez a história termine "dando razão a Marx" ${ }^{\text {"521 }}$, evidência assegurada, para o francês, nas análises de Florestan Fernandes.

A impotência e o limite da ordem constitucional formal é o fundamento daquele repudio à "luta somente pela liberdade" em oposição à ditadura. ${ }^{522}$ Florestan Fernandes, sem a facilidade teórica oferecida pela eliminação da finalidade revolucionária, precisa articulá-la às formas políticas que a luta de classes deve assumir. Some-se ainda a problemática da institucionalização do conflito, aspecto daquela perseguição pela modernidade possível na periferia, e se terá um quadro dramático de dilemas no limite de uma solução teórica. Como condenar a conquista da democracia formal num contexto em que ela não se realizou historicamente, a ponto de tornar legítima e rotineira a participação de partidos representantes das camadas populares? Contudo, como contentar-se com ela, se “essa participação é responsável por efeitos inibidores na sua contestação radical da ordem social”? ${ }^{523}$ Se há uma estratégia de legitimação do próprio sistema político na condução "lenta gradual e segura" da abertura, também a adesão às soluções dentro da ordem, nesse momento, parecem-lhe produzidas por ela mesma, como forma de cercear o potencial contestador. ${ }^{524}$ A ordem seria reposta e legitimada através da contestação que se ativesse a seus limites. A aposta no possivel dentro da ordem seria signo pródigo da debilidade crônica e da força selvagem dessa ordem: “a 'revolução contra a ordem' vai perdendo impulso, ao passo que a 'revolução dentro da ordem' vai sendo modelada, em nome da manutenção dessa mesma ordem". 525 Ambivalência em plano político que se manifesta também no plano de seus papéis, pois, o propósito de "apanhar história e estrutura no movimento de vir a ser" ${ }^{526}$ coloca em jogo o publicista e o sociólogo. É do métier do segundo a apreensão em plano estrutural das persistências e "padrões", ao passo que o campo do primeiro é a emergência da história, como força negadora da estrutura. Eis um aspecto privilegiado para denotar o papel legado à sua

\footnotetext{
${ }^{521}$ Idem.

${ }^{522}$ Brasil: em compasso de espera, p. 57.

${ }^{523}$ Paulo H. Martinez, "Prefácio", p. 17.

${ }^{524}$ Brasil: em compasso de espera, p. 11.

${ }^{525}$ Paulo H. Martinez, "Prefácio", p. 17.

${ }^{526}$ A natureza sociológica da Sociologia, p. 31.
} 
"formação acadêmica" nesse contexto, que não é simplesmente eliminada, mas será, contudo, mobilizada segundo uma dinâmica distinta àquela institucional.

A saída encontrada teoricamente para o impasse - que em jargão marxista define-se por "reforma ou revolução" - consiste em supor que a conquista da democracia e que a luta contra a ditadura sejam um momento daquele objetivo final de natureza revolucionária. Entretanto, como essa saída se expressa historicamente? A inserção na nova esquerda se faz especialmente problemática nesse contexto, em que as posições teóricas estão sob o imperativo de se tornarem prática política, crescentemente marcada por um vínculo partidário, para o que concorrem especialmente o fim do bipartidarismo e a ascensão de diversos movimentos de contestação populares. Como lembra Daniel Pécaut, "a intervenção política dos intelectuais manifesta-se cada vez mais na inserção de cada um nos partidos políticos" nos quais se distribui a oposição - o (P)MDB, o PT e, em menos proporção, as demais formações partidárias surgidas pós 1982." 527

É indubitável que a "emergência do Povo na história" redireciona a angulação das análises de Florestan Fernandes - expressa em seu "marxismo-leninismo" e em sua atuação enquanto publicista. Contudo, enfrenta, à altura da fundação do PT, um impasse pungente, que o cinde novamente: a fidelidade à sua interpretação da história, articuladora de socialismo e democracia como rupturas revolucionárias com a ordem; ou adesão a um partido que não lhe parece corresponder a ela. A peculiaridade de nosso desenvolvimento capitalista se manifestaria em definitivo na não-emergência de sujeitos revolucionários? Se é certo que o problema não se equaciona mais nos termos daquela bifurcação sem saída, uma vez que a contestação social se faz presente - e as próprias instituições se revigoram com isso - não reconhece no vínculo partidário mais factível no quadro político, a efetiva ruptura com o padrão de reprodução de circuito fechado da ordem capitalista periférica, quando de sua fundação. Então, que papéis "o intelectual pode desempenhar na luta de classes, quando situado ao lado dos trabalhadores?" 528 - é dúvida que continua a torturar Florestan Fernandes. Até porque, ele não quer "repetir" erros. Assim, se no Canadá, considerava que, por conta de sua imprecisa definição social, a contestação intelectual ia da defesa da "consolidação da democracia", da "revolução através do desenvolvimento" até a "revolução contra a ordem", estando marcada por "incongruências insuperáveis" típicas "da ambigüidade

\footnotetext{
${ }^{527}$ Os intelectuais e a política no Brasil, p. 260.

${ }^{528}$ Paulo H. Martinez, "Prefácio", p. 17.
} 
do 'esquerdismo' nas sociedades capitalistas subdesenvolvidas" 529 - nesse momento, essa crítica se atualiza e se manifesta em histórica recusa em entrar no PT, pela ausência de uma precisa orientação socialista - única, para o autor, capaz de romper com a conciliação e com a "democracia" que se forja pela anuência da ditadura. A aproximação política e intelectual com o núcleo da "nova esquerda", através do aceite ao convite de Otávio Frias Filho, para escrever semanalmente na seção "Tendências e debates" do privilegiado espaço de agregação político-cultural de oposição ao regime militar que era a Folha de S. Paulo ${ }^{530}$, já em 1983, terá concorrido para que, em 1986, optasse por aderir ao Partido, ainda que criticamente, e tendo por objetivo precípuo a candidatura a deputado federal, cargo no qual esperava realizar suas expectativas quanto ao aproveitamento político racional dos intelectuais - infelizmente frustradas. ${ }^{531}$ Por outro lado, podem ser identificadas afinidades eletivas entre a atuação do PT na Campanha pelas eleições diretas para Presidência da República e sua recusa em participar do Colégio Eleitoral e a perspectiva geral de Florestan Fernandes em relação à "abertura". Elas talvez tenham atraído o sociólogo, pois ele também optava por "apontar os limites da transição conservadora que se esboçava", ainda que isso lhe custasse certo "isolamento político", tal como o PT, em sua oposição tanto a Paulo Maluf, quanto a Tancredo Neves, e polêmica ausência no Colégio Eleitoral. ${ }^{532}$

Os episódios factuais e a densidade da problemática não devem tirar nosso foco. $\mathrm{O}$ esboço do editor, do publicista e as dificuldades no plano teórico-político entram em consideração, pois concorrem para a redefinição do papel intelectual. Seus desdobramentos encontram-se na base da reflexão que encerra esse estudo. Indicá-los é imperativo.

Em primeiro lugar, é significativo que nesses anos a temática dos papéis intelectuais se manifeste numa heterogênea gama de textos - distinta de certa unidade que caracteriza em conjunto a produção atinente ao período do exílio e o subseqüente. Tanto o curso A natureza sociológica da Sociologia quanto a própria Coleção Grandes Cientistas Sociais propiciam que o autor se expresse acerca dos papéis intelectuais. Considere-se ainda um estilo singular e inédito de elaborar a reflexão acerca deles, denominado Compactos Críticos. Não por acaso, é em Brasil: em compasso de espera, publicação lapidarmente representativa do perfil que aqui se designou de publicista - entre outros motivos, por compilar escritos de densidade

\footnotetext{
529 “A ditadura militar e os papéis políticos dos intelectuais na América Latina”, p. 130-131.

${ }^{530}$ Carlos Alberto Furtado Mello, Imprensa e democracia, p. 162.

${ }^{531}$ Há muitos depoimentos acerca de sua passagem pelo Congresso Nacional. Vale mencionar sua participação no programa Roda Viva, em novembro de 1994, quando, já com a saúde debilitada, não se furtou a retomá-la, e expor suas críticas ao PT.

${ }^{532}$ Rachel Meneguello. PT: a formação de um partido, 1979-1982. Rio de Janeiro: Paz e Terra, 1989, p. 199.
} 
sociológica, de análise de conjuntura, em diversas modalidades, que vão do artigo à entrevista, para a imprensa nanica e para a grande imprensa - que o autor os define. ${ }^{533}$ Os Compactos são entrevistas, nas quais entrevistado e entrevistador se encontram em recíproca cumplicidade quanto ao conteúdo crítico e ao valor político das indagações e das respostas, originando uma "forma" que fica "a meio caminho entre a entrevista comum, o artigo e jornal e a reportagem", são "obras de parceria, de jogo à meia, de colaboração intelectual”. 534 Como pondera, cada momento histórico engendra "formas de comunicação entre dissidentes e públicos insatisfeitos”. Portanto, o Compacto é adotado, não apenas pela liberdade propiciada pelo descompromisso com a formalidade da reflexão, porém como forma possível da crítica em tempos sombrios, e, por isso, atesta "que as tribunas improvisadas são construtivas e levam o debate aos desertos em que deveriam imperar a mudez, a cegueira e a surdez."535

A simplicidade desses textos não deve ocultar a significativa nuança: a parceria intelectual e a assinatura conjunta da crítica elimina parcialmente a distinção entre entrevistado e entrevistador, leitor e cientista. A cumplicidade estabelecida orienta o sentido daquilo que é dito. Da mesma maneira que o diálogo estabelecido nos cursos da PUC-SP, muito menos entre professor-especialista e aluno-receptor, mas marcado por uma compreensão da relação entre sujeitos políticos iguais, tem-se nos Compactos Críticos o testemunho pródigo da reflexão encetada num gênero nada profissional, aberto primordialmente ao diálogo, e mesmo à inserção dos interlocutores como sujeitos ativos na produção de sua própria reflexão. Assim, a problemática condição intelectual, ao atravessar lugares de enunciação diversos define um espaço interdiscursivo de reflexão cuja multiplicidade de interlocutores retira a metalinguagem do tendente ensimesmamento, que a encerra no núcleo mais próximo dos praticantes daquele métier. Essa perspectiva da igualdade entre os interlocutores na esfera da discussão política é formulada em bela avaliação de sua participação na Campanha pela Escola Pública, ao declarar que através dela tenha descoberto "que não se deve incentivar o isolamento do intelectual", ainda que este tenha posições reacionárias, pois “todo o processo de discussão democrática legitima o

\footnotetext{
${ }^{533}$ É de se lamentar que uma seção tenha que apontar tantas ramificações do estudo e não possa desenvolvê-las. Manda a prudência, contudo que assim o seja. Por isso, mencione-se que seria bem vindo trabalho que analisasse sistematicamente as publicações de Florestan Fernandes nos anos setenta, como chamam atenção e mesmo a esboçam, Paulo Silveira e Paulo H. Martinez. Deveria ser objeto de detida reflexão, os temas, a perspectiva analítica sobre eles, os vínculos com sua interpretação do Brasil, com a conjuntura política e suas atividades editoriais. É salutar, em carta de 25/08/1978, a satisfação, peculiar no conjunto da correspondência, com que comenta o sucesso das publicações e, em tom típico, a falta de entusiasmo com a docência ("Florestan Fernandes por ele mesmo", p. 165).

${ }_{534}$ Brasil: em compasso de espera, p. 229-230.

${ }^{535}$ Idem, p. 230.
} 
antagonista"; o que é "importante no meio brasileiro", em que "sempre prevaleceu o monopólio conservador da verdade. E, a partir do momento da ebulição da crítica, da discussão, do diálogo, esse monopólio se esboroa e desaparece." ${ }^{536}$ É válido notar como a defesa da abertura ao debate público se presta à preocupação com o estabelecimento de uma esfera pública protagonizada por iguais - a despeito da "voz qualificada" do cientista social ou qualquer outro especialista. Tudo se passa como se, ao se colocar, e aceitar, portanto, o outro como interlocutor, o intelectual não legitimasse apenas a sua posição, mas a própria esfera pública, cuja razão de ser está no conflito e na igualdade entre as partes.

Por conseguinte, distancia-se o autor daquele código "que definiu tanto as condições de produção, quanto as de recepção de suas obras", "alicerçado no primado do conhecimento científico" 537 - ao menos enquanto código exclusivo. Se desde o início de sua carreira, Florestan Fernandes estabeleceu diálogo com a sociedade em geral, é certo que esse diálogo era irradiado pela centralidade da condição institucional e do estilo de pensamento a ela vinculado. No período em exame, a interlocução não encontra correspondente à instituição no período anterior, parecendo obedecer antes à dinâmica da "desobediência civil", atendendo o primado da multiplicidade de pares e das possibilidades de empreendimento da crítica. Talvez por isso, o tratamento do cientista social segundo um esquema analítico que buscava definir o "intrínseco" à sua atividade, típico dos artigos escritos no Canadá, deslocou-se para a problemática das relações que as atividades intelectuais travam com outras atividades sociais - exemplarmente verificado na análise d'A natureza sociológica da Sociologia acompanhado de uma ampliação de interlocutores na problematização da condição intelectual.

Um segundo aspecto a ser assinalado, diz respeito a expressivo deslocamento no tempo, da questão ciência e da condição intelectual. A produção teórica do publicista cela em definitivo um estilo de apreender os problemas no âmbito político da luta de classes e nos termos da história in flux. Por isso, Florestan Fernandes não se ocupará das oposições entre os papéis desempenhados pela ciência social no capitalismo monopolista e no "socialismo real". Fará, porém, de sua palavra de ordem - "o que os caminhos que levam à preservação e ao fortalecimento do capitalismo ou à transição para o socialismo significam para a ciência peculiar que os sociólogos podem e devem fazer" - um norte para reflexão. ${ }^{538} \mathrm{~A}$ problemática central a ser enfrentada, então, consiste na ciência social e no intelectual,

\footnotetext{
${ }^{536}$ A condição de sociólogo, p. 64.

${ }^{537}$ Maria Arminda do Nascimento Arruda, Metrópole e cultura, p. 316.

${ }^{538}$ A natureza sociológica da Sociologia, p. 18.
} 
enquanto agentes do desencadeamento do processo que faz ingressar a sociedade no curso propriamente revolucionário. A virtualidade revolucionária da emergência de los abajo concorre, evidentemente, para que a reflexão tome tal rumo.

Por fim, a emergência dessa voz, dissonante no cenário político, é ensurdecedora nos escritos de Florestan Fernandes. As tarefas revolucionárias presentes - e isso não deixa incólumes os próprios intelectuais - estão com los de abajo. Eles herdam as tarefas históricas não cumpridas da burguesia periférica, bem como as que não poderiam cumprir os intelectuais modernos oriundos da revolução encetada por ela - dentre as quais tem destaque a própria conquista da autonomia do pensamento. Essa emergência social é determinante, enquanto resposta política precisa, oriunda "dos humildes, dos excluídos e marginalizados", "dos setores sociais" considerados "categoria social amorfa: a plebe analfabeta e ignorante". ${ }^{539}$ Se foram a "vanguarda operária e o movimento sindical" que indicaram "como se deve orquestrar a desobediência civil ao despotismo" e "se a ordem burguesa só pode se alargar por um dilaceramento que nasce fora das classes burguesas", então, "qualquer que seja a situação de classe do universitário e sua condição profissional, ele tem de se aliar ao combate das massas populares, das classes trabalhadoras e da vanguarda sindical do proletariado., ${ }^{540}$

O declínio do protagonismo do intelectual, encetado teoricamente desde 1970, encontra espaço nesse cenário político e histórico para a inversão em definitivo do lugar do intelectual como "elemento de vanguarda na consciência dos problemas sociais",541 Aquela voz se torna desconcertante, desdobra-se mesmo na proposta de uma subordinação intelectual no processo revolucionário, e na identidade entre este e o movimento socialista na realização do par socialismo/modernidade, sinonímia já assinalada, que legitima tal subordinação. Eis a matéria-prima de nossa última seção.

\footnotetext{
${ }^{539}$ Brasil: em compasso de espera, p. 56.

${ }^{540}$ Idem, p. 56-57.

${ }^{541}$ A Sociologia numa era de revolução social, p. 87. (O texto é de 1962).
} 


\section{3. Autonomia intelectual e revolução.}

Em 1983, a celebração do centenário de falecimento de Karl Marx era um imperativo para aqueles que, no Brasil, mergulhados na luta pela famigerada abertura política, identificavam-se com a linhagem da esquerda revolucionária. Não é de se estranhar que além do valor simbólico de que a filiação teórica se revestia, enquanto prova da integridade ideológica de seus adeptos - servissem também essas cerimônias de pretexto para pensar a conjuntura política e a luta de classes na qual se envolvia a oposição ao regime militar, cujo desfecho, há muito iminente, tardava, contudo, a se concretizar. A presença de Florestan Fernandes em inúmeras dessas ocasiões originou textos de singular expressividade. Neles, são salientes: o procedimento do paralelismo histórico com o contexto brasileiro, a modulação da linguagem, o aproveitamento da oportunidade para tratar de diversas temáticas e ampliar sua interlocução. Entre eles, não se pode dizer que haja uma diferença substantiva nas posições defendidas. Nesse conjunto, porém, aquele no qual a problemática de afeição desse trabalho se equaciona lapidarmente encontra-se na "Introdução a Marx/Engels", para a coletânea da Coleção Grandes Cientistas Sociais, em sua seção de História. É sobre ele que nos debruçamos agora.

Já vimos, na apresentação elaborada por Florestan Fernandes para Lênin, que trajetórias intelectuais identificadas com a atuação política revolucionária lançam aquele que a ela se dedica, ao cerne de uma equação básica: autonomia do conhecimento e dever de militância. Dito de outra forma, diante da trajetória de ativistas, são os dilemas do próprio Florestan Fernandes que vêm à tona. Outrossim, considere-se que o marxismo tem como um de seus problemas definidores a questão da unidade entre teoria e práxis. A crescente aproximação do autor às perspectivas definidoras dessa tradição, implicaria inexoravelmente, no enfrentamento da questão em seus termos. E, uma vez colocado o problema da inserção política do intelectual no campo do marxismo, é do debate acerca daquela unidade que germina a compreensão do papel intelectual. Observar como o autor a concebe vem a ser decisivo, portanto.

Duas ressalvas talvez sejam aconselháveis inicialmente. O uso desse texto para o propósito do trabalho pode gerar objeções. Poder-se-ia argumentar que o que encontramos aí não sejam as posições Florestan Fernandes, mas simplesmente as de Marx e Engels. A legitimidade da advertência, contudo, não altera a possibilidade do procedimento. Há trechos 
significativos em que encontramos asserções marcadamente de Florestan Fernandes e de sua interpretação - o que se averigua, inclusive, pelo uso de termos próprios ao seu constructo e ligados ao sentido que tomam em seus escritos, como "ordem", "autocracia burguesa". Em outros, há a prescrição normativa explícita. Outrossim, ficando rente ao procedimento de selecionar a problemática desenvolvida, segundo fatores que se remetem a problemas e impasses da análise da condição intelectual feita pelo autor e destacando como o tratamento das trajetórias de Marx e Engels vem atender a demandas dessa mesma análise, a leitura do texto é proveitosa. Além disso, convém mencionar, consta no escopo da fortuna crítica, evidentemente, a querela: "Florestan Fernandes - marxista?", centrada em torno, especialmente, da concepção d'A revolução burguesa no Brasil. Optar por sua definição como marxista não é o ponto principal dessa apresentação - que tem por objetivo precípuo apreender a equação prática/teoria do ângulo de suas formulações acerca do papel social e político da ciência. ${ }^{542}$

A "Introdução a Marx/Engels" declara como propósito pôr em relevo "as idéias centrais de K. Marx e F. Engels sobre a ciência da história". ${ }^{543} \mathrm{O}$ autor não deixa dúvidas quanto à consideração de que esta ciência possa eventualmente encontrar sua manifestação na história que os autores produziram como historiadores. Contudo, não é o métier do historiador que a define. A "ciência da história" de que fala o autor está fundamentada na perspectiva de "história como síntese", em oposição à fragmentação e especialização - "a universidade e a especialização criaram um processo profundo" de "fragmentação do trabalho de investigação", assim, "o sociólogo, o historiador, o antropólogo, o cientista político, o psicólogo, mesmo quando marxista" estão submetidos a isso. Entretanto, "Marx e Engels trabalharam numa direção oposta, defendendo uma concepção unitária de ciência representando a história como uma ciência de síntese." $" 544$

Dessa maneira, Florestan Fernandes não procura apreender a produção de Marx e Engels do ângulo sociológico, historiográfico, ou de qualquer outra área circunscrita - ao contrário, critica, inclusive, as tentativas de enquadrá-lo nas especializações científicas contemporâneas. Há nesse empreendimento um contraponto evidente com relação às suas primeiras investidas no marxismo, cujo objetivo era extrair as contribuições especificamente

\footnotetext{
542 Não podemos aqui adentrar nesse debate - cujo encaminhamento, contudo, nos parece sensatamente empreendido por Carlos Águedo Paiva em: "Florestan, o obscuro e o liberalismo monárquico". Estudos Avançados, maio, 1997, vol. 11, n. 30.

543 “Introdução a Marx/Engels", p. 9.

${ }^{544}$ Idem, p. 10.
} 
sociológicas - o que então se subordinava à reflexão teórica e metodológica necessária na fase juvenil da institucionalização da Sociologia, como mostra Maria Arminda do Nascimento Arruda. ${ }^{545}$ Esse distanciamento, contudo, não se deve apenas à pertinência de Marx ao campo das discussões políticas. Vimos como Lênin, autor dileto da tradição do marxismo clássico, pôde ser apreendido no interior de parâmetros primordialmente institucionais-científicos, chegando mesmo o sociólogo a postular a legitimidade de suas idéias, segundo suas contribuições às Ciências Sociais. ${ }^{546}$ Assim, se a tradição do marxismo clássico, na figura de Lênin é apreendida segundo sua contribuição à "sociologia como ciência crítica e objetiva" e Marx/Engels, segundo a elaboração da "ciência social histórica", termo com o qual o autor denomina a especificidade da gênese desse pensamento, é porque os parâmetros de avaliação e a finalidade da análise se distinguem, de acordo com as preocupações que o mobilizam.

Menos que haurir no campo institucional científico os parâmetros de valor que legitimam a produção intelectual, a "Introdução a Marx/Engels", através da crítica ao processo social de organização e produção do saber especializado, elabora uma proposta para o exercício da autonomia intelectual que se apresenta como contrapartida daquele posicionamento político “contra a ordem”. Essa crítica terá como alvo básico o caráter fragmentado do saber, tanto no plano de sua organização social, que cinde "produtores" e "consumidores", quanto em sua produção intelectual em franco processo de especialização e racionalização das áreas de conhecimento, apontado como limitador da compreensão global dos grandes processos. Mutatis mutandis, o problema evoca Walter Benjamin, empenhado em pensar a eliminação das fissuras entre especialistas/ artistas e interlocutores/leitores na produção cultural, através de uma proposta de organização da atividade cultural que rompa com tais cisões, convocando o "consumidor" para a "produção". 547 É certo que Benjamim oferece sugestões ímpares para se pensar a questão, embora esteja ausente do rol de autores diletos de Florestan Fernandes. O interessante está em notar que, contextos históricos distintos e autores tão distantes se ocuparam do mesmo problema, o que parece ser sinal de que encaminhá-lo é próprio da agenda intelectual dos que se engajam visceralmente no curso histórico que lhes cabe viver.

\footnotetext{
${ }^{545}$ Metrópole e cultura, p. 318.

546 “Introdução", p. 22-23.

547 “O autor como produtor". In.: Obras escolhidas. Magia e técnica, arte e política. São Paulo: Brasiliense, 1985.
} 
O cerne da "concepção unitária de ciência", da "história como uma ciência de síntese ${ }^{, 548}$, encontra-se na dinâmica que engendrava a produção intelectual de Marx e Engels. Caso o lócus de produção fosse o âmbito institucional, a gênese dela estaria no próprio desenvolvimento da ciência, cuja seriação condiciona que um cientista prossiga e/ou rompa a seu modo a obra dos outros-pares: dinâmica que caracteriza o campo autônomo. Porque Marx e Engels "trabalharam numa direção oposta" à da instituição universitária, puderam elaborar uma ciência de síntese. Para que tal pensamento não se fragmentasse, era necessário que o processo de sua produção não se desse no interior das instituições, que têm nesse procedimento, o fundamento de sua organização e dinâmica produtiva. Precisamente, não é esse o caso da produção fora da instituição: a dinâmica da produção do pensamento é outra, pois a demanda que o engendra é outra.

Nesse passo, o autor poderia facilmente ser acusado de anacronismo. Como afirmar que Marx e Engels tenham mérito e valor por recusarem ser inseridos no sistema universitário de especialização fragmentada, se o processo histórico que dá origem à especialização acadêmica criticada era ainda incipiente? No entanto, é justamente isso que nos indica o valor do aproveitamento desse texto para que se tome em consideração, não Marx e Engels, mas a compreensão de Florestan Fernandes sobre eles nos marcos das transformações pelas quais passa sua reflexão acerca do problema da autonomia intelectual. Neste e em outros textos, como já foi mencionado, é possível se observar uma "atualização" da história a partir de seus problemas coevos. É factível, portanto, que a raiz desse anacronismo se encontre em um dos motores da crítica: a militância do "partido intelectual", centrada na bandeira da "profissionalização".

Contudo, a ausência de vínculo institucional não garantia por si mesma a autonomia intelectual. Colocar-se contra a ordem é desvincular-se dela, pela via do desligamento institucional, para vincular-se à força social que pode destruí-la revolucionariamente. Segundo o autor, "o cientista que se coloca fora da ordem estabelecida por causa de sua vinculação com o proletariado também fica acima das deformações que ela impõe à pesquisa científica". ${ }^{549}$ O fundamento dessa autonomia desvinculada institucionalmente porque vinculada em termos de classe, estaria numa compreensão de teoria e práxis enquanto momentos de uma única unidade, a da luta política. Daí que se rompa com o intervalo técnico-social que cinde "produção" e "aplicação", ou "absorção" do conhecimento. Intervalo

\footnotetext{
548 “Introdução a Marx/Engels", p. 10.

549 “Introdução a Marx/Engels", p. 20.
} 
este na origem dos impasses de Florestan Fernandes, e que Walter Benjamin chamaria de "enfadonha dicotomia": "por um lado devemos exigir que o autor siga a tendência correta, e por outro lado temos o direito de exigir que sua produção seja de boa qualidade." 550 Concebidas enquanto unidade concreta, ou seja, que se faz conjuntamente, e rompido portanto aquele intervalo, o vínculo com o proletariado e a âncora de objetividade fundada na eficácia e na verdade - seriam reconfigurados. ${ }^{551}$

É imperativo que se saliente, especialmente no atinente à crítica ao limitado desafio à ordem a que se restringiu sua geração, como é sensível, nessas afirmações o desdobramento de seus depoimentos. Daí que, ao tratar dos vínculos institucionais, a ênfase se dirija não ao "desafio" à ordem, mas à ruptura com a mesma - promovida não apenas pela produção desligada da instituição, mas ligada à classe social que corporifica historicamente tal ruptura, vínculo este, ausente e impossível nos tempos de sua vicejante geração, dramaticamente perdida. Ademais, pode-se ainda supor que nessa equação do desligamento institucional com o vínculo à classe revolucionária encontrem-se ecos de sua própria recusa em retornar, por ocasião da Anistia em 1979, à Universidade de São Paulo. Afinal, vimos como o sentido conferido pelo autor à sua recusa se articula à luta política, que não quer legitimar a natureza da contra-revolução permanente, expressa na iniciativa do regime, mas deve desvelar a conciliação de classe em jogo naquele processo político.

A redefinição que esse trabalho encontra é tributária da busca pela ruptura com aquele intervalo técnico e social entre produção e absorção. O vínculo com a classe implica na incorporação desta no corpo analítico enquanto sujeito da história - em sua dupla e única dimensão: produzida intelectualmente e vivida politicamente. A "ciência de síntese" é uma história do presente, pois sua matéria-prima é a ação do seu sujeito no presente, ação esta que é a própria negação desse presente. Daí a necessária incorporação também do futuro, através da categoria "revolução", que confere sentido aos fatos daquela matéria - pois, na medida em que, tanto a ação do sujeito histórico, quanto o futuro são a negação do presente, este seria um mero amontoado disforme de fatos sem um eixo que lhe atribuísse significação. Por isso, o

\footnotetext{
550 "O autor como produtor", p. 121.

${ }^{551}$ Note-se, se joga papel decisivo o empenho pela unidade entre teoria e prática nessa concepção de autonomia, esta se fundamenta numa determinada concepção de revolução autocrática burguesa, na qual o tipo de dominação de classe se manifesta na natureza fechada das instituições e da sociedade que a reproduz e mantém a ordem. De forma tal que, está postulada uma identificação entre o vínculo de classe e o vínculo institucional que, por sua, vez implica em que a ruptura com a ordem burguesa seja recíproca à ruptura com a instituição. Trata-se de um esquema substancialmente distinto do de Gramsci, por exemplo, no qual, a questão de classe sobrepuja o espaço institucional - pois distingue a classe social dos organismos institucionais sob sua direção. (Ver essa discussão em: Antonio Carlos Maximo. Os intelectuais e a educação das massas. O retrato de uma tormenta. Campinas: Autores Associados, 2000, p. 106)
} 
empenho da "ciência social histórica" consiste em "desentranhar o futuro que está contido e oculto no presente, descobrir o comunismo e ter de decifrar o que ele representa em uma sociedade na qual não existe lugar para ele". A "história na forma de ciência" incluía "o comunismo não só em seu objeto, mas também em seu ponto de vista explicativo."

Se a classe revolucionária não se reduz a um objeto de análise, por conseguinte, o intelectual não se coloca na esfera compartimentada de produção do saber, lugar que lhe confere a concepção de vanguarda da razão que esclarece os demais, nem se serve dos problemas sociais para fazer avançar sua ciência. É ele que, ao servir, “incorpora-se à vanguarda da classe e não fala em nome dela". Ao contrário, "é ela quem fala através de seus intelectuais de vanguarda, que enunciam, pela ótica do comunismo, as condições objetivas da formação e evolução da classe, as quais são, por sua vez, as condições objetivas da revolução proletária (isto é, da dissolução da sociedade burguesa e da instauração de uma sociedade nova)." ${ }^{553}$ Assim, a "recusa" à segregação entre consumidores e produtores de conhecimento conforma a proposta de uma superação dessa cisão, não mais através da ação pedagógica de vanguarda esclarecida. Nessa concepção, o sujeito revolucionário, para ser historicamente ativo, não pode ser cognitiva e politicamente passivo.

As formulações apresentadas convocam a questão do declínio do protagonismo intelectual paralelamente à aposta nas condições políticas oferecidas pelo protagonismo social dos movimentos de contestação. Com efeito, a equação da relação do protagonismo intelectual com a subjetividade política dos grupos sociais dissidentes encontram formulações distintas em momentos distintos. Vimos que, inicialmente, a remetência de um à política e de outro à ciência, guardados seus espaços institucionais, deixa o sociólogo à mercê das oportunidades de engajamento oferecidas socialmente, deslocando, com relação a seu projeto acadêmico político, a direção vetorial da transformação, que não mais vai da Sociologia à sociedade, mas da sociedade à Sociologia. Já nos depoimentos, ganha proeminência uma subjetividade negativa dos dois lados, como se ambos tivessem seu papel histórico esvaziado na dinâmica da (contra)revolução burguesa e do capitalismo dependente. Assim, ambos, intelligentsia e de los abajo encontram condições de se realizarem historicamente apenas na modernidade plena, marcada pela racionalização das relações sociais, considerada viável apenas no socialismo. Se aí há um passo fundamental na direção da junção de ambos numa unidade política, nessa "Introdução a Marx/Engels" se observa não apenas uma diminuição do

\footnotetext{
552 "Introdução a Marx/Engels", p. 29-32.

${ }^{553}$ Idem, p. 20.
} 
protagonismo do intelectual em relação à sociedade, mas uma proposta de igualdade de subjetividade, que inverte a relação na qual o "Povo", a sociedade, o movimento socialista são objetos do cientista, de modo que os dois lados passam a constituir um "sujeito" historicamente ativo. A proposição da adesão em termos classistas, como garantia para autonomia intelectual se coloca, portanto, como um elemento dessa proposta mais geral de ruptura com a organização e produção do saber especializado, sentido mesmo da concepção sintetizada pela denominação "ciência de síntese".

A prudência prescreve que não se aventure na seara dos parentescos entre essas formulações e questões sociológicas que ocuparam o autor no início de sua carreira, entretanto, a evidência manda que as mencione. Afinal, como "intervir na organização da personalidade e preparar o homem para viver em uma sociedade secularizada e planificada?" 554 era parte constitutiva do escopo de seu projeto acadêmico político. Essas preocupações tomariam forma de indignação diante da "anomia social" - marcando a feição de um estudo como A integração do negro na sociedade de classes. A emergência do "Povo na História" receberia diversas problematizações, mas permaneceria genuinamente em seu horizonte de investigação. Nos escritos de meados dos anos setenta, o papel do intelectual seria tratado desse ângulo, referenciando e refutando aquele "mandato público" que caracterizou os abolicionistas à la Joaquim Nabuco, pois "os que aceitam um mandato que não é expressamente delegado, por mais puros que se revelem no seu desempenho, pertencem certamente ao nível social dos que oprimem e dos que mandam”. ${ }^{555}$ Daí afirmar que não devemos "lutar pelo Povo", mas estarmos a serviço dele, para que adquira "com a maior rapidez e profundidade possíveis, a consciência de si próprio e possa desencadear, por sua conta, a revolução nacional que instaure no Brasil uma ordem social democrática e um Estado fundado na dominação efetiva da maioria." ${ }^{, 556}$ Cabe lembrar também que a preocupação com os desdobramentos sócio-políticos da moderna separação das esferas - na qual a forma de produção do conhecimento, segregada numa categoria de profissionais em âmbito especializado da vida social, propicia a condição de "objeto" e "consumidor" do conhecimento à outra parcela da sociedade - faz parte de preocupações sociológicas de largo espectro e longa data de Florestan Fernandes e acompanha as transformações de suas elaborações. Como vimos, em seu projeto acadêmico encontrava-se a proposta de intervir também no sentido da "racionalização do aproveitamento da inteligência" - em oposição ao

\footnotetext{
554 "A Sociologia Aplicada: seu campo, objeto e principais problemas", p. 147.

${ }^{555}$ A revolução burguesa no Brasil, p. 165.

556 "A geração perdida", p. 246.
} 
"estilo liberal", em que o uso social do conhecimento é visto como um processo regulado espontaneamente pela dinâmica da própria sociedade. ${ }^{557}$

Como o autor não cede à corrente eliminação da revolução para o equacionamento de suas posições, a fragmentação fomentada pela profissionalização e pela especialização, na escala acelerada da forma conservadora que toma a modernização, emerge ao nível epistemológico propriamente dito, porque ela impede a elaboração de uma interpretação global que dê sentido à ação política. A problemática d'A natureza sociológica da Sociologia é evidentemente evocada. Pois há uma atenção cerrada à forma singular que a dominação burguesa assume no capitalismo monopolista, mediando a noção de que nele, "a impregnação burguesa do pensamento sociológico seja profundamente anti-histórica"558 e adentra a ciência ao se propor como o único e imutável modelo de ordem. Esse entendimento alicerça, evidentemente, a noção de que deva também a subversão da ordem emergir na produção mesma do conhecimento, através da negação do presente, introduzida pela perspectiva da revolução enquanto categoria de análise. Introdução esta possível, pois oposta ao pensamento anti-histórico, está em oposição à perspectiva de aproveitamento ou de manutenção da ordem, mas se liga à força social que "equivale ao outro lado do rio" e "se abre diretamente sobre e para a história, já que é ao nível da história que ela se inscreve", através da qual "se atinge o fundo da realidade”. Pois a história, enquanto negação das estruturas, revela a natureza da ordem, e enquanto irrupção social revela ao cenário político que "não é a burguesia, como classe dominante", mas "os trabalhadores como classe revolucionária, que põem em evidência a natureza da sociedade capitalista." ${ }^{559}$ Assim, se a emergência de los abajo faz emergir a história, da mesma maneira, o pensamento contra a ordem deve voltar-se a ela, para negar aquela ciência tecnocratizada, vazia de história.

A evidente ligação entre as formulações teóricas de A natureza sociológica da Sociologia e a "Introdução a Marx/Engels" daria matéria para capítulo à parte. Deve-se assinalar que, por época em que lecionava o curso referente àquela publicação, é provável que a concepção da "Introdução a Marx/Engels" já estivesse em curso. ${ }^{560}$ É inegável que haja entre os textos um contraponto e uma reciprocidade intrínseca. Enquanto $A$ natureza sociológica da Sociologia trata de delinear, precipuamente, a ordem capitalista monopolista gestando um tipo de pensamento orgânico e como seria a ciência social no socialismo; na

\footnotetext{
557 “A Sociologia Aplicada: seu campo, objeto e principais problemas”, p. 128.

${ }^{558}$ A natureza sociológica da Sociologia, p. 72-73.

${ }^{559}$ Idem, p. 31.

${ }^{560}$ Como se deduz de nota explicativa. Idem, p. 78.
} 
"Introdução a Marx/Engels" trata-se de bosquejar como se forja nessa mesma ordem uma ciência que a negue em plano prático e político - faces de uma mesma moeda, nascidas do mesmo processo histórico, que, por sua natureza dialética, origina tanto as "forças da ordem" como as “contra a ordem". Tudo se passa como se n'A natureza sociológica da Sociologia tivéssemos duas ordens sociais, a capitalista monopolista e a socialista, e o tipo de ciência social que originam. Já na "Introdução a Marx/Engels", a ciência não é pensada segundo a ordem sócio-histórica adequada a seu desenvolvimento, mas no processo histórico que destrói a ordem capitalista e constrói a socialista. A preocupação dirige-se não para o que seja a ciência social em uma ou outra ordem, mas o que pode ser no processo revolucionário que leva de uma a outra ordem. Assim, como a subjetividade política e histórica da ciência é inoculada na etapa monopolista do capitalismo, é enquanto força atuante no processo de destruição da ordem capitalista que ela reconquista sua subjetividade histórica. Esses fatores iluminam mesmo o acolhimento do volume Marx/Engels na seção de História da Coleção pois seria numa retomada das relações que o pensamento revolucionário estabeleceu com a História, que poderia se elaborar uma proposta de prática científica antagonista àquela cujo fundamento é o "Fim da História", a chamada "sociologia da ordem".

O tipo de conhecimento apresentado na "Introdução a Marx/Engels" opera a síntese, portanto, no próprio tempo, pela incorporação do futuro, possível em razão da categoria "revolução", e do sujeito dessa tarefa histórica, especificamente como sujeito da história vivida e produzida. A "ciência de síntese" quer opor-se à ordem negando o quê dessa ordem há no interior de sua própria atividade, mirada viável através de uma atividade que elimine a fragmentação dos objetos de estudo e a segregação entre os sujeitos do conhecimento.

Eis o princípio fundamental que orienta a reflexão. É ele que permite um grandioso salto de uma espécie de reação e resposta às adversidades políticas e sociais que inviabilizam seu projeto acadêmico político à elaboração de um programa para a inserção intelectual e produção científica. Por isso, a congruência procurada - entre a aposta na ruptura da ordem no plano político e seu desdobramento no plano intelectual - seria encontrada nessa "Introdução", na qual o posicionamento político básico, revolução contra a ordem, socialista e democrática, estabelece uma unidade de sentido com a reflexão acerca da condição intelectual, eliminando o impasse acenado no início de sua autocrítica, entre a autonomia e a instrumentalização da ciência.

Nesse sentido, não parece casual que dentre inúmeros problemas deixados em suspenso no processo reflexivo de que esse trabalho se ocupa, destaque-se a retomada da 
postulação ética do engajamento, marcante no período em que esteve no Canadá. Naquele momento, o socialismo consiste na civilização típico ideal que compartilha o ethos científico em sua própria organização, por conta da afinidade entre a ciência e seus "valores". É evidente que as rearticulações entre ciência e socialismo, verificadas ao longo do período de nosso interesse, são devedoras das modificações que sofrem as concepções acerca da relação entre capitalismo, ciência e modernidade. Assim, é certo que "a revolução pela ciência" começa "depois e através" 561 de uma revolução política - mas nessa equação, pressuposto e finalidade são idênticos e simultâneos, pois se "a revolução pela ciência" é ulterior à política, como ela pode participar ativamente da revolução? Somente quando a problemática se dirigisse ao que deve ser a ciência enquanto o "depois" não chega e o "através" é o próprio presente, o autor sairia da circularidade em que redunda a asserção. A emergência da revolução no seio do que pretende ser a produção do conhecimento é fruto de significativos deslocamentos impressos à ciência na revolução e na ordem social, por sua reflexão. Efetivamente, o lugar da ciência na revolução se modifica, acompanhando as nuanças mais amplas. O "depois" é indubitavelmente tema privilegiado em A natureza sociológica da Sociologia, especialmente quando estão em tela as questões referentes à URSS. O "antes" consta paralelamente na reflexão, quando paradigmaticamente os EUA servem de parâmetro para esquadrinhar a condição do pensamento sociológico no capitalismo monopolista.

O deslocamento para o "durante" é marcado por um esforço em sair do campo da ética como base de legitimação do engajamento. Indagado, em 1981, sobre o teor ético de seus posicionamentos, responderia: “O que é chocante, aqui, não é a obrigação ética e abstrata que eu teria com meus ideais", pois o problema se coloca "ao nível prático da congruência da opção". Ou seja, devo "sair do conformismo adaptativo. Porque o que caracteriza o nosso socialismo é que ele não rompe com a ordem. Ele convive com a ordem", a "pessoa aceita esta adaptação, esta convivência do indivíduo que considera socialista, mas ao mesmo tempo aceita e deseja tudo o que a sociedade capitalista dá. E não leva a ruptura até o fim.” E, em derradeira indagação: "Você acha que seria possível conciliar a revolução bolchevique com isso?"562

Como assinala Maria Arminda do Nascimento Arruda, a virada do autor se expressa justamente "na conciliação entre pensamento científico e revolução e no desencanto em

\footnotetext{
561 "Sociologia, modernização autônoma e revolução social", p. 151.

562 “A pessoa e o político", p. 22-23. A indagação foi: (seus posicionamentos podem) "até levar a uma ideologia da pobreza (...) não será levar demasiadamente, de forma muito profunda para o plano ético, este dilema?" (Idem, p. 22).
} 
relação aos papéis profissionais do sociólogo". ${ }^{563}$ Com efeito, a identidade especificamente socialista do intelectual é delineada. Florestan Fernandes, adentrando o terreno da dialética no qual o engajamento é pressuposto da qualidade cultural e abandonando o dualismo do "engajamento, mas qualidade cultural" - contorna a dificuldade de tomar por base a posição política socialista para erigir seu programa intelectual, tão evidente no apelo ao critério ético como fundamento da militância, que defendia no início de 1970.

Indubitavelmente, é o amálgama entre a os tortuosos caminhos da história presente e os de sua reflexão que promove essa virada. Vimos, como, em seus depoimentos, a análise da condição intelectual centrava-se em torno do que lhe era negado pela revolução democrática, mas não no que lhe fosse exigido pela revolução socialista. Esta era antes, tão impossível quanto a revolução democrática, abortada por uma modernidade cambiante. A emergência de los abajo, no final dos setenta, desafiaria a reflexão a novos rumos, marcadamente para o problema presente, debruçando-se então o autor sobre as "possibilidades da história em processo." ${ }^{, 564}$ Por outro lado, nesses mesmos depoimentos, a crítica à organização e à produção do saber propicia uma crescente desconfiança com relação aos critérios de instauração e consolidação de valor científico - condição básica para a ruptura assinalada. Uma vez que os critérios de valor qualitativo das obras culturais se produzem no interior do campo de produção dessas obras, estabelecido pela ordem, seria na saída desse campo de valorização e na instauração de outro parâmetro, que se poderia elaborar tal crítica.

A "Introdução a Marx/Engels" evoca a equivalência estabelecida entre a ciência comprometida com a ordem e a ciência comprometida com a contestação da ordem, por volta de 1970, quando o autor postulava uma inexorável condição de apropriação instrumental da ciência pela luta política. A distinção dessa apropriação - à esquerda ou à direita, e a favor ou em oposição aos regimes militares, como então se colocava o problema - era vista em termos éticos, que indicavam com qual facção social se articulavam as contribuições do cientista social. Ora, diante da natureza da crítica proposta em seus depoimentos e nos cursos da PUC$\mathrm{SP}$, supor que os movimentos contra a ordem possam instrumentalizar os elementos da ordem, entre eles a ciência, a seu favor, torna-se uma irrisão. Exatamente a força selvagem da ordem contra-revolucionária do capitalismo monopolista está em que somente seus fins determinam a intrumentalização das coisas -inclusive através da produção de movimentos contestatórios que se limitem à instrumentalizar a própria ordem. É compreensível, portanto,

\footnotetext{
${ }^{563}$ Metrópole e cultura, p. 251.

${ }^{564}$ A natureza sociológica da Sociologia, p. 12.
} 
que Florestan Fernandes deixe o terreno em que se encontrava, no qual a estrita divisão de esferas e pertinência das competências ordenava a dissociação entre produção e absorção do conhecimento - e procure traçar outro espaço para equacionar o comprometimento político e o científico. Por isso, abandona os termos da "enfadonha dicotomia" que equaciona o problema da autonomia, "qualidade e opção política", e com isso implode o terreno político sobre o qual tal perspectiva se erige.

Daí, a saída de uma estratégia defensiva do discurso, que se fazia predominante quando a legitimidade era almejada nos alicerces dos adversários que pretendia combater, ou seja, dentro do estrito respeito à "ordem”. Ao longo desses anos, encontramos Florestan Fernandes propondo a "dupla polarização dos papéis intelectuais" ${ }^{, 565}$, e se defendendo de uma "neutralidade científica" em stricto sensu, sem que a dinâmica da produção do saber que origina a polarização cindida fosse, ela mesma, questionada. Da mesma forma, apontamos como se esforça para que a instrumentalização do saber seja convertida para o lado político de sua afeição. O registro aí é o da exploração da inexorabilidade da ordem para seu fim político. Talvez por isso, o que apontamos como cisuras elementares no projeto acadêmico político não chegassem a compor uma unidade de sentido, mas permanecessem pulverizadas, tendo por opositor precípuo um interlocutor reportado à defesa da neutralidade científica, alicerçando-se na ética para tanto. Contudo, uma vez concebida sociologicamente a negação revolucionária da ordem como única alternativa política à "dominação autocrática da burguesia" - tanto no capitalismo periférico, quanto no capitalismo monopolista central - é estabelecido o limite desta solução e autorizada a transgressão da ordem, inclusive no que diz respeito à organização e produção do saber.

Tudo se passa como se a condição de suspensão institucional fosse equacionada enquanto ruptura com parâmetros institucionais de produção cultural, somente após mais de uma década de experiência fora da instituição acadêmica. Para isso, parece ter concorrido fundamentalmente o esquema interpretativo acerca da revolução burguesa no Brasil, que convoca a ruptura com a ordem e concebe como "conciliação" toda espécie de instrumentalização da ordem, para favorecer aos "de baixo" - modalidades de "ditadura de classe burguesa dissimulada e paternalista". ${ }^{566}$ Destarte, desdobra-se no desvelar do limite da instrumentalização do conhecimento produzido nos quadros da ordem, manifesto no apelo à ruptura desta também no plano da produção e organização do saber.

\footnotetext{
${ }^{565}$ COMISSÃO EDITORIAL. “Apresentação”. Debate e crítica. Revista semestral de ciências sociais, n. 1. São Paulo: Hucitec, julho, 1973, p. 4.

${ }^{566}$ A revolução burguesa no Brasil, p. 342.
} 
A nova proposta é possível ainda, por Florestan Fernandes ter encontrado o fundamento sócio-político da síntese - de que carecia historicamente, desde as aproximações com o universo do marxismo clássico e das primeiras fissuras no constructo acadêmico político. Se em suas reflexões no exílio a idéia de uma intelligentsia era questionada, em função dos vínculos de classe que a atravessavam, lecionando na PUC-SP, a relação entre a sociologia e o antagonismo social da sociedade de classes é matéria de longa reflexão, tendo destaque a problemática das condições que propiciam ou invalidam a síntese científica. Nesse momento, há uma validação de Mannheim pelo autor, no atinente à síntese: "voltássemos a Mannheim e à sua idéia de síntese pelo próprio movimento mais radical, complexo e avançado" e veríamos que "a classe revolucionária contém todas as determinações que vinculam dialeticamente o desmoronamento do capitalismo e a construção do socialista". 567 No entanto, a apreciação do referencial dileto não deve ocultar a substantiva alteração da "garantia estrutural de validade" do conhecimento.

Há um deslocamento do papel ocupado anteriormente pela razão no plano lógico e pela intelligentsia socialmente, para a racionalidade do movimento revolucionário. Além disso, a síntese não se realiza numa sociedade de natureza fragmentada, mas numa sociedade futura em que a síntese teórica e social consista na própria dinâmica histórica - ou seja, no processo que vai da revolução socialista à sociedade comunista -pois, essa civilização "com potencialidades de expansão contínua" oferece "tendências à unificação teórica que não puderam operar por falta de ambiente propício", aliás, "como elas poderiam florescer no estreito solo da especialização profissional e do isolamento acadêmico?" ${ }^{568}$ Há uma recíproca (im)possibilidade em tela: a (im)possível síntese sociológica por complementaridade das perspectivas é análoga à (im)possível "síntese" social, senão através da "revolução contra a ordem". 569

Estas são nuances que se cristalizam na reflexão aqui apresentada, mas reverberam a silenciosa gestação da crítica elaborada ao longo da década de 1970. A diversidade social na constituição da intelligentsia, desde então, menos que oferecer a síntese das perspectivas sociais, foi questionada como congérie política, ineficaz e desprovida de identidade ideológica. Se a pluralidade de perspectivas e a multiplicidade de experiências sociais, bebidas em Mannheim como âncoras da possibilidade de síntese para o meio intelectual, não

\footnotetext{
${ }^{567}$ A natureza sociológica da Sociologia, p. 32.

568 Idem, p. 145.

569 Miriam Limoeiro Cardoso, Para uma história da sociologia no Brasil: a obra sociológica de Florestan Fernandes, p. 36.
} 
servem mais de base, a adoção do referencial leninista acoplada à ausência histórica de agentes que possam representar essa síntese não oferece condições para elaboração de um novo constructo. O retorno a Marx e o reconhecimento dos agentes na virtualidade histórica no interior de uma crítica intelectual encetada ao longo da década de setenta e mergulhada nas vicissitudes da conjuntura política - seriam os fatores que propiciariam o arremate encontrado na "Introdução a Marx/Engels".

Em suma, contra o "modo como o capitalismo tardio apropria-se da racionalidade cognitiva, passando a orientar a produção científica segundo os fins específicos da reprodução da ordem e da dominação" e que castra "de forma violenta a força emancipatória potencial" do "pensamento racional e da atividade intelectual profissionalizada nas universidades e institutos e laboratórios de pesquisa" ${ }^{570}$ - Florestan Fernandes propõe a violação de supostos requisitos do profissionalismo, como a adesão à instituição e a respeitosa aderência da intervenção à competência específica, tornando-a o pressuposto de uma prática comprometida com a efetiva autonomia científica.

A significação dessas posturas é adensada por serem oriundas daquele que foi o artífice da institucionalização da ciência social, defendendo-a como força instauradora da moderna civilização ocidental, sem que para tanto fosse necessário o questionamento de sua realização no interior do capitalismo. O mesmo autor conclui, contudo, pela ruptura com as esferas, necessária não para a impossível autonomia científica no capitalismo, mas para que se torne força política no detonar de um processo revolucionário de destruição deste. E, em decorrência, entende que se a autonomia científica realiza-se apenas na racionalização social, que sua expectativa atribui à revolução socialista/comunista, no interior da ordem capitalista ela só adquire papel histórico se subverter a forma pela qual é socialmente produzida. Se, no plano da biografia intelectual e política, esses deslocamentos espelham a integridade e a coerência de Florestan Fernandes, considerando os desafios históricos que enfrentou e fomentou tais equacionamentos, talvez não haja metamorfose individual mais expressiva de nossa formação complexa e de nossa difícil realização enquanto civilização moderna.

\footnotetext{
${ }^{570}$ Sylvia Gemignani Garcia, Destino impar, p. 164.
} 


\section{Consideracões Finais}

...o ausente está presente, como sempre.

Florestan Fernandes

Como vencer o oceano se é livre a navegação mas proibido fazer barcos? Carlos Drummond de Andrade

Os anos que compreendem o período a que dedicamos esse estudo não são marcados pelo esplendor daqueles em que Florestan Fernandes foi arauto da institucionalização da moderna Sociologia brasileira. Nosso percurso começa precisamente naquele momento em que o arrocho do regime militar, através do AI-5 e das aposentadorias compulsórias, arranca-o do nicho em que concentrava o cerrado empenho na realização de um projeto acadêmico político, elemento constitutivo de seu próprio projeto de vida.

Acompanhar as delicadas nuanças em seu trajeto, após essa cicatriz irreversível em sua identidade, é perscrutar o enfrentamento do fracasso das expectativas individuais e coletivas que pulsavam no coração de seu projeto, cuja aposta nas forças vetoras da modernidade contra o arcaísmo não deixava dúvida quanto à iminente superação do "atraso" em relação à civilização moderna ocidental. Através das metamorfoses que sofre a reflexão acerca da condição do cientista social e das condições de realização do intelectual moderno esse trabalho pôde percorrer o tortuoso caminho que liga a concepção desse projeto à convicção de sua impossível realização, senão através de uma via revolucionária contra a ordem. Vista como um todo, a trajetória de Florestan Fernandes amalgama os períodos históricos de aposta na modernidade e dúvida quanto à sua própria viabilidade, expressa nesses anos, que, se não são áureos, elucidam, contudo, a historicidade de seu projeto de modernidade.

A aposentadoria compulsória - em que se atribua o devido peso a ela -certamente concorreu para que o aspecto reflexivo de seu pensamento se intensificasse. Ao se colocar diante "dos desdobramentos do seu projeto, submetido, a partir de seu afastamento da universidade, à prova das circunstâncias" e dos dilemas de uma história "que escapava à racionalidade de uma ciência forjada na relação com a experiência acabada da modernidade" ${ }^{571}$ - fatalmente, indagar-se acerca do sentido dos seus esforços e reconstruir tal sentido era tarefa urgente. É na condição de estrangeiro, que as primeiras fissuras no projeto acadêmico começariam a se processar. Entre 1969 e 1972, na qualidade de latin american in

\footnotetext{
571 Maria Arminda do Nascimento Arruda e Sylvia Gemignani Garcia, Florestan Fernandes, mestre da Sociologia moderna, p. 10.
} 
residence lectures, não pouparia seus interlocutores - pouco próximos, decerto, daqueles acontecimentos que animava melancolicamente a produção dos artigos - da discussão acerca das relações entre as ditaduras latino-americanas e os intelectuais colaboradores das mesmas, verdadeiro disparate no interior de suas concepções acerca do cientista social.

A idéia de que nos momentos em que não se consegue delimitar os papéis intelectuais tal tarefa seja especialmente necessária, é lapidar nesse momento. Nem sempre o intérprete de Florestan Fernandes pode trazer para seu texto a dinâmica do pensamento do autor, senão custando-lhe extensas citações - por isso, contenta-se em indicar sentidos que se apreende ao longo das sofridas páginas que o autor concebe em meio a seu desesperado esforço por definir, diagnosticar e encontrar a recomendação mais precisa, sem que a ela consiga chegar. Dentre eles, merece destaque o desencontro entre o diagnóstico das situações e prescrição da ação - ligação factível de se esperar num autor como ele. Não raramente se observa que o esboço de asserções propositivas são logo abortados e cedem a novo percurso analítico, sinalizando o impasse de seu avanço e o recuo face ao imperativo de propor um agir, como signo da própria insatisfação do autor quanto à compreensão desenvolvida e da dificuldade de se forjar uma prática eficiente de resistência. Pode-se afirmar, por isso, que suas recomendações em torno de uma "sociologia da revolução", de fundamento ético, não são um desdobramento das potencialidades verificadas na análise da condição intelectual e sua imbricação com os regimes autoritários, mas um “a despeito" das limitações postas, repostas e esgarçadas por ela.

Retornando ao Brasil, sem motivo aparente para tanto, e com razões inúmeras para permanecer no Canadá, amarga solitariamente em sua "gaiola de ouro", na ebulição de suas reformulações teóricas, em confronto com suas elaborações pretéritas. A expressão pública desse enclausuramento não tardaria. Viria sob a forma de um duplo retorno ao passado - no plano teórico, através da retomada e conclusão de A revolução burguesa no Brasil, e em plano autobiográfico, através da elaboração de sua história de vida. Faces de um mesmo processo de reconstituição de sua identidade intelectual, esses escritos mediam os diagnósticos a que chega nesses dois níveis e seus desdobramentos, nas tomadas de posição junto a questões afeitas à conjuntura política e na nova orientação de conduta intelectual que elabora.

A modernidade periférica e a "geração perdida" são seus objetos principais, de modo que a primeira ilumina o sentido dos fracassos da segunda. $\mathrm{O}$ alinhave sociológico com que vinca sua geração aos rumos históricos nacionais é oferecido pela natureza de nossa revolução 
burguesa. De modo que, entende que o meio intelectual, como as forças vetoras da modernidade, absorve e é absorvido pela debilidade da floração da ordem moderna, e se constitui sob a égide da reprodução de seu modelo autocrático burguês. Por isso, não entra em conflito, não se opõe, não exerce plenamente sua modalidade de intervenção pública - a intelligentsia opera como força de manutenção do mesmo status quo que a cerceia. Tributária da ordem social em que nasce e dos vínculos de classe que atravessam as instituições nesse modelo - a intelligentsia não conquista sua autonomia, porém a obtém por consentimento. E, como não é autônoma, não pode universalizar seus valores para a sociedade, ao contrário, é suscetível à invasão da ingerência e desmandos externos no campo institucional, de que supostamente é sua a agência social. Ainda que em forma de depoimentos, há aí uma verve teórica, que enquadra a recente inviabilização de seu próprio projeto acadêmico político de modernidade. Não por acaso, o tema do fracasso é especialmente forte nesses relatos, perdendo proeminência apenas no terceiro período, quando as expectativas estão voltadas para o presente, com a vívida aposta na superação desse fracasso, pela aposta nos movimentos dissidentes.

Fica patente diante disso que se a "adesão de Florestan Fernandes à ciência caminha pari passu com a forte ligação à universidade" ${ }^{, 572}$ - o desligamento e a crítica desconcertante a esta, não eliminam do horizonte a adesão à ciência. A aposta na ciência se mantém, $a$ despeito e não por causa das instituições, crescentemente identificadas com as forças sufocantes da ordem capitalista periférica, que abortam a realização da emancipação prometida pela modernidade originária. Dessa maneira, a convicção racionalista na ciência opõe a sociologia como ciência à sociologia como profissão, resguardando à primeira os valores corrompidos pela segunda. Embora a "sociologia como ciência" tenha se transformado estritamente em "sociologia profissional"573, para Florestan Fernandes, o controle social e político sobre a ciência só ratifica sua concepção, segundo a qual, a Sociologia "enquanto ciência" é intrinsecamente revolucionária - "há uma tentativa desesperada de bloquear esse impacto, sob o temor pânico de que a ciência poderia acelerar a decomposição da 'era burguesa', convertendo o capitalismo monopolista no fim de um ciclo histórico". 574

Não seria sem obstáculos que a reconstituição autobiográfica - marcada por um crivo sociológico, que converte o sujeito em seu próprio objeto de análise, tornando-o afinal, outro

\footnotetext{
${ }^{572}$ Maria Arminda do Nascimento Arruda, Metrópole e cultura, p. 326.

${ }^{573}$ A natureza sociológica da Sociologia, p.59.

${ }^{574}$ Idem, p. 61.
} 
para si mesmo - seria empreendida. Entre o distanciamento necessário e o envolvimento inexorável, desenvolve-se a autocrítica, emergindo um emaranhado de asserções conflituosas - movidas por duas versões precisas: a que retoma compreensivamente o sentido da própria ação, e a que procura explicar sua derrota política à luz das novas conclusões teóricas e posições políticas, e, portanto, não sem tom anacrônico. Mesclada à crise de identidade, a lapidação do próprio passado adensa um estrangeirismo com relação ao próprio tempo e espaço formador. Essa experiência está imbricada com as formulações que orientam a crítica pungente à militância intelectual pautada no credo profissional - inteligível à luz das transformações no interior do meio intelectual, articuladas com as condições políticas, que delimitam a bandeira da democracia como válida dentro de uma coerência com a profissão e com a intervenção pública. Entretanto, para Florestan Fernandes, marginalmente situado do ponto de vista institucional, a articulação dessa coerência, já encetada, no mínimo, há décadas, oferece matéria para crítica.

A categoria que desempenhava no constructo acadêmico político, de inspiração mannheimiana, o papel de uma "garantia estrutural da validade", não encontra substituto lógico, que leve a crítica à elaboração de uma nova proposta de intervenção, nem novo suporte social - papel que, aventado aos movimentos de contestação, esvai os mesmos na dinâmica da reflexão, pois na ausência de sólidas forças políticas revolucionárias, o que se manifesta senão a força sufocante da ordem que não produz sua negação? Não terá sido fácil a constatação de que o tipo de atuação idealizada naquele esquema acadêmico político não garantisse necessária e intrinsecamente a liberdade e a autonomia intelectuais, em seu teor modernizador e democrático. Se a "autonomia", que respeita suas delimitações no plano institucional, pode não apenas conviver, mas atender às demandas políticas do regime autoritário, na figura da modernização acelerada da produção dos bens simbólicos, tomá-la como pilar de uma prática intelectual de resistência implica em dissociá-la da instituição que a abriga. De forma geral, nesse segundo momento, o autor enfrenta o impasse, de quem se vê diante da força da ordem e da ausência da contestação - e, ao mesmo tempo, recusa-se veementemente a aceitar seu ofício como um mero exercício de reprodução dessa mesma ordem.

Contudo, o desdobramento em nível programático da reflexão concentrada em meados dos anos setenta só viria posteriormente. É certo que seus depoimentos ferem mortalmente o coração de seu projeto acadêmico político, mas não encetam a congruência entre a perspectiva da ruptura com a ordem no plano político e um papel intelectual correspondente a ela. 
À crise que fissura seu projeto acadêmico político corresponde, portanto, no movimento de retorno crítico ao próprio passado, a perda definitiva de expectativas que ainda pairavam em seus escritos do período em lecionava na Universidade de Toronto - cristalizada especialmente na adesão à perspectiva de "revolução contra a ordem", cuja contraface é a condenação das soluções dentro da ordem como máscaras da "conciliação", imbricada à crítica institucional que empreende.

O terceiro período estudado é marcado por uma sui generis atividade docente, compreendida como "desobediência civil" - cujo propósito é transformar em prática política e intelectual, a crítica que figura nos depoimentos. Acende-se novamente uma chama que convoca "o combate feito por todos e que aproveita a todos" $" 575$, transformando tudo e todos em guerrilhas e guerrilheiros. A desobediência civil na PUC-SP faz dela uma dessas frentes de luta; tanto quanto a recusa, do alto de seu capital simbólico, ao retorno à USP, através de uma Anistia infame. Assim, entende que "expostos à impotência que manietou a sociedade brasileira, dos estudantes e professores aos operários destituídos, tentamos mostrar que uma pedagogia de contestação, se recusa ao silêncio." 576

A desobediência civil se articularia à crítica teórica, cabalmente cristalizada em seus Apontamentos sobre a "teoria do autoritarismo" e n'A natureza sociológica da Sociologiaobra que consiste em tradução teórica das considerações a que chegou através do relato em primeira pessoa, generalizando as dramáticas e definitivas conclusões d'A revolução burguesa no Brasil e de sua autobiografia intelectual, para o âmbito do pensamento sociológico produzido no capitalismo monopolista. Com isso, a racionalidade da ordem passa a ser apreendida como a própria irracionalidade e é sedimentada a noção de que o papel da atual profissionalização não consiste em garantir aquilo a que é supostamente destinada - a autonomia e a precisão científicas - mas em meio de inserção no e absorção do sistema econômico. A atual "profissionalização" garantiria um isolamento social e interditaria uma autonomia científica - que, erigindo a fragmentação, o pragmatismo e a abstração da história como critérios de elaboração e valoração científica, submete em definitivo o pensamento. Por isso, o que era pré-requisito para autonomia - atuação estrita à esfera de competência à la intelligentsia moderna originária - torna-se sua maior ilusão, na base do que concebeu como "desobediência civil na esfera acadêmica". ${ }^{577}$ A ruptura com a ordem, defendida politicamente, manifesta-se na ruptura com uma de suas fiéis escudeiras, a instituição

\footnotetext{
575 "Tarefas dos intelectuais na revolução democrática", p. 53.

576 Apontamentos sobre a "teoria do autoritarismo", p. XX.

${ }^{577}$ Idem, p. XIX.
} 
universitária. Entretanto, se em seu equacionamento, a realidade histórica não empresta à prática científica a possibilidade de resistência ou oposição, qual seria a pólvora que reacenderia a chama ardente que o manteve vivo até o fim de seus dias?

Não seria a atividade docente. Porém, aquilo que historicamente poderia conferir sentido político a ela: a eclosão de los abajo no cenário político nacional. É certamente o calor dessa chama que se encontra no fundo do publicista que leva aos extremos as vicissitudes e as virtualidades possíveis histórica e politicamente - tanto na direção da realização revolucionária de suas expectativas, quanto, especialmente, na direção da conciliação e da eterna recomposição política por cima, sob o controle das camadas dominantes. Em última análise, Florestan Fernandes enfrenta os impasses entre a certeza e incerteza de uma interpretação da história que se vê diante de um processo histórico em curso; que demanda uma atuação política, a ser elaborada a partir da luta de classes e de uma perspectiva especificamente revolucionária, o que implica em assumir o imprevisível no corpo de um programa que se quer prospectivo, indicativo - desafio tormentoso ao sociólogo afeiçoado ao "controle racional". Publicista, editor, entrevistado, articulista de jornais nanicos e da grande imprensa - aí figuram tudo o possível e todos os papéis que pudesse açambarcar com sua arredia convicção revolucionária - revérbero sim, de uma indomável personalidade, mas sobretudo do empenho pela análise precisa, sem a qual aquela não se sustentaria política e intelectualmente.

As críticas acumuladas à intelligentsia controlada, não autônoma, cooptada pelo capitalismo monopolista transvertido nos louros do prestígio profissional, à instituição e aos centros de pesquisa, somadas à tábula rasa que faz da teoria a partir da crítica teórica parecem encontrar razão de ser no retorno - que se postergou no tempo, muito embora fosse o desdobramento lógico, se não tivesse de ser convocado pela história - a Marx e na conformação de uma prática científica que fosse historicamente ativa no processo que conduz do irracionalismo que a aliena para um racionalismo que a emancipe, expectativa que tem por pressuposto então, a sociedade socialista.

Será a partir do tratamento conferido à trajetória intelectual, teórica e política que origina a ciência social histórica que Florestan Fernandes trataria da questão não do que seja a ciência no capitalismo monopolista ou no socialismo - mas de como ela participa do processo que leva do primeiro ao segundo. Para equacionar em seus termos, a questão passa a 
ser, como constituir um pensamento já "liberado" no interior da sociedade "não liberada". 578 O eixo da reflexão se altera - e passa das oportunidades perdidas e dos equívocos no tempo pretérito, para as oportunidades presentes. A reflexão sobre o passado, focada nas limitações, cede cena ao presente que convoca cerrada atenção às possibilidades - deslocamento que se manifesta tanto nas análises conjunturais em que a história é a negação da estrutura, quanto na problemática da identidade intelectual, manifesta na "Introdução a Marx/Engels".

A passagem de Mannheim a Lênin não se completa, portanto, sem um retorno a Marx - que propõe complexas relações, marcadas pela múltipla contemporaneidade, compartilhada por cientista, sociedade e conhecimento, pela subjetividade histórica de intelectual e movimento revolucionário, por uma modalidade distinta de objetividade científica que elimina o intervalo técnico, social e político entre produção e absorção do conhecimento. No caminho que leva de uma a outra ordem social, a ciência não assume as mesmas funções que tinha em seu projeto primeiro - estas estão mesmo postergadas a uma sociedade que já se encontre em vias de consolidação do socialismo, e superação dele, na direção do comunismo. No processo revolucionário, a ciência se identifica com as forças e sentidos cerceados pela natureza da (contra)revolução burguesa e da dominação do capitalismo monopolista, através de uma contra-irracionalidade, que seria, ela sim, a racionalidade emancipadora originária da modernidade. Por isso, intelligentsia e los de abajo concretizam uma unidade - pois, eliminados, em suas expectativas, pelo capitalismo monopolista, constituem-se como forças cuja realização histórica se vincula à destruição dele e à subseqüente realização da modernidade numa sociedade socialista. Há, indubitavelmente, em suas formulações uma determinante "oposição entre a racionalidade histórica da burguesia" e a "a racionalidade tida como intrínseca à atividade científica". ${ }^{579}$ Oposição esta que permite associar as condições de realização da modernidade à sociedade socialista, especialmente se socialismo for entendido como "a continuidade do esforço de fazer da sociedade uma relação de pessoas nitidamente humana", única saída política para aqueles que "não vêem qualquer motivo para que a produção não seja diretamente regulada (para a) comunidade como um todo". 580

Com efeito, é a junção dos rumos da reflexão com a emergência histórica inédita dos de abajo que viceja nos escritos de Florestan Fernandes no final dos setenta. O reconhecimento - ainda que sofridamente lúcido com relação aos "perigos políticos” em jogo

\footnotetext{
${ }^{578}$ A natureza sociológica da Sociologia, p. 97.

${ }^{579}$ Miriam Limoeiro Cardoso, Para uma história da sociologia no Brasil: a obra sociológica de Florestan Fernandes, p. 32.

${ }^{580}$ Karl Polanyi. A grande transformação: as origens da nossa época. Rio de Janeiro: Campus, 1980, p. 59.
} 
- daquilo por que obstinadamente perseguiu, através de caminhos teóricos, sociológicos e socialistas, atravessados politicamente pelo drama do desencontro, alimenta a "chama interior". A concepção racionalista de ciência, resguardada junto a este calor, afina-se a ele através da utopia de "racionalização da vida social" ${ }^{581}$, projeto último que dá sentido às suas convicções, numa nova proposta de intervenção intelectual, acoplada a um processo histórico especificamente revolucionário, no qual deposita a expectativa da efetiva instauração de uma ordem compatível com a ciência enquanto saber racional. A confissão, num Compacto Crítico, é direta, sincera e lúcida:

“os problemas centrais estão fora das instituições universitárias e estão dentro da sociedade (...) são problemas que dizem respeito à dominação imperialista e à hegemonia burguesa. Portanto, não vejo o problema como o de uma volta à Universidade. Eu nunca abandonei as causas pelas quais lutei. Eu não desertei daquelas causas e não vejo a minha volta como uma retomada da 'normalidade'. Não existe isso (...) não desertei das nossas causas. Não preciso da universidade para ser intelectual e cumprir minhas tarefas como eu as vejo (...) poderia parecer orgulho, empáfia. Porém, quase sempre essas explosões verbais possuem um significado muito profundo. É uma tentativa de mostrar que a minha rebeldia sobreviveu por outros meios, e que tem outro solo histórico. E esse solo não está dentro da Universidade." 582

Sobrevivente rebelde, a autocrítica foi uma das fontes da veemência com que defendia suas posições. Por isso, reconstituía-se, reformulava-se, refazia-se com rigor mais austero, talvez, que o de seus próprios críticos. Esse traço fez com que concepções se transformassem justamente para que as causas não fossem jamais abandonadas - como esse trabalho espera ter mostrado.

Aqueles que se debruçam sobre a trajetória de Florestan Fernandes não podem fugir às questões que o presente ainda lhe coloca - como desdobramento de problemáticas às quais ele se dedicou e nas quais a história presente ainda se vê envolta. Dentre elas, há aspecto indissociável dos deslocamentos que sofre sua obra nos anos setenta e dos rumos que toma no início dos anos oitenta.

Na constatação de uma modernidade precária, a intelligentsia era o agente social que assumia tarefas resultantes dessa debilidade de formação. Florestan Fernandes tributava então às forças de modernidade, nascidas no seio do arcaísmo, o dever de superá-lo, encaminhando o conjunto social na direção da secularização e da racionalização. Contudo, o excesso de tarefas delegadas aos intelectuais revelou-se um equívoco, pois a formação débil da modernidade se refletia na incapacidade de exercerem seus papéis básicos. Diante desse novo equacionamento, as tarefas históricas não cumpridas, nem pela burguesia, nem por sua

\footnotetext{
${ }^{581}$ Sylvia Gemignani Garcia, Destino impar, p. 164-165.

582 “Revolução não se faz na Universidade”. In.: Brasil: em compasso de espera, p. 292-293.
} 
intelligentsia foram delegadas a los de abajo. Eles cumpririam tarefas pendentes da modernidade, numa revolução que seria também a alternativa histórica ao modo de produção capitalista a que ela se liga inicialmente.

Teriam essas tarefas sido realizadas por eles, ou o capitalismo na periferia consiste numa perpétua constituição de agentes históricos fracassados, porque dispensáveis à realização da modernidade possível? Uma ambivalência ainda insolúvel responde essa questão. E nas duas formas de enunciá-la, repõe-se, extemporaneamente, o dilema de Florestan Fernandes. Num registro socialista, a reforma teria amortecido o ímpeto revolucionário de negação da ordem - ratificando os ardis da mesma, através da absorção dos partidos representativos das camadas populares nos dispositivos cerceadores da ordem legal. Entretanto, em registro sociológico, tal absorção à ordem institucional e a rotinização das atividades dos partidos dessa natureza, não expressariam precisamente a realização de aspecto fulcral daquela modernidade almejada - a institucionalização do conflito político? Poderia se supor, que da oscilação inicial em participar da fundação do PT, por duvidar de sua precisa orientação socialista, à adesão ao mesmo, na qualidade de candidato à deputado da Assembléia Nacional Constituinte, Florestan Fernandes tenha recuado daquela radicalidade e retornado às suas expectativas de sociólogo comprometido com a instauração da ordem moderna, para o que a institucionalização dos conflitos políticos era elementar.

E, no entanto - em termos de um fracasso da perspectiva socialista, ou de um sucesso, da perspectiva sociológica - é inconteste o sentimento social generalizado de que a modernidade parece não se realizar plenamente. Os impasses enfrentados por Florestan Fernandes parecem recolocados, fruto da atualização que a história confere à obra do sociólogo. A própria homogeneização - em âmbito cultural, político, social e econômico empreendida pelo capitalismo tardio parece não apagar, mas repor os dilemas da formação, através do trágico percurso que conduziu a sociedade brasileira "diretamente de iletrada e deseducada a massificada, sem percorrer a etapa intermediária de absorção da cultura moderna". ${ }^{583}$ Terá, entre as oportunidades históricas perdidas, também se esvaído a possibilidade de um sólido enraizamento de valores modernos, a despeito da modernidade incrustada na vida material? Um trabalho como esse não poderia ser encerrado senão com uma indagação dessa natureza.

\footnotetext{
${ }^{583}$ João Manuel Cardoso de Mello e Fernando Novais, “Capitalismo tardio e sociabilidade moderna”, p. 640.
} 


\section{Documentação e bibliografia}

\section{Livros, artigos, ensaios e entrevistas de Florestan Fernandes.}

FERNANDES, Florestan. A Etnologia e a sociedade no Brasil. Ensaio sobre aspectos da formação e desenvolvimento das ciências no Brasil. São Paulo: Anhembi, 1958.

Companhia Editora Nacional, 1967.

Fundamentos empíricos da explicação sociológica. São Paulo: . Elementos de Sociologia Teórica. São Paulo: Companhia Editora

Nacional, 1970.

. "A Sociologia Aplicada: seu campo, objeto e principais problemas". In.: Ensaios de Sociologia Geral e Aplicada. São Paulo: Pioneira, 2a ed. 1971.

Dominus/Edusp, 1965, 2v.

A integração do negro na sociedade de classes. São Paulo:

. "Autodefesa". In.: A Sociologia no Brasil. Contribuição para o estudo de sua formação e desenvolvimento. Petrópolis: Vozes, 1977.

. The latin american in residence lectures. Toronto: University of

Toronto, 1969/1970.

- "Sociologia, modernização autônoma e revolução social". In.:

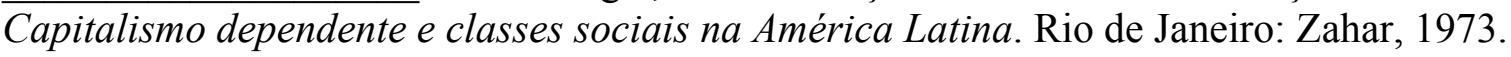

$2^{\mathrm{a}}$ ed., 1974.

. Mudanças sociais no Brasil. São Paulo: Difusão Européia do Livro,

. Sociedade de classes e subdesenvolvimento. Rio de Janeiro: Zahar,

$3^{\mathrm{a}}$ ed., 1975.

. A universidade brasileira: reforma ou revolução? São Paulo: Alfa-

Ômega, 1975.

- A revolução burguesa no Brasil. Ensaio de interpretação

Sociológica. Rio de Janeiro: Zahar, 1975.

. A Sociologia numa era de revolução social. Rio de Janeiro: Zahar,

$2^{\mathrm{a}}$ ed. reorganizada e ampliada, 1976.

- "A ditadura militar e os papéis políticos dos intelectuais na América Latina". In.: Circuito fechado. Quatro ensaios sobre o "poder institucional". São Paulo: Hucitec, 1976.

. "Sociólogos: os novos mandarins?" In.: A Sociologia no Brasil.

Contribuição para o estudo de sua formação e desenvolvimento. Petrópolis: Vozes, 1977. 
. "Sociologia e socialismo". In.: A Sociologia no Brasil. Contribuição para o estudo de sua formação e desenvolvimento. Petrópolis: Vozes, 1977.

. "Em busca de uma sociologia crítica e militante". In.: A Sociologia no Brasil. Contribuição para o estudo de sua formação e desenvolvimento. Petrópolis: Vozes, 1977.

- “A geração perdida". In.: A Sociologia no Brasil. Contribuição para o estudo de sua formação e desenvolvimento. Petrópolis: Vozes, 1977.

. "A Sociologia como contestação". In.: A Sociologia no Brasil. Contribuição para o estudo de sua formação e desenvolvimento. Petrópolis: Vozes, 1977.

. "Democracia e desenvolvimento". In.: A Sociologia no Brasil. Contribuição para o estudo de sua formação e desenvolvimento. Petrópolis: Vozes, 1977.

. "Apresentação". In.: AZEVEDO, Licínio e RODRIGUES, Maria da Paz. Diário da libertação: a Guiné Bissau da nova África. São Paulo: Versus, 1977.

. Circuito fechado. Quatro ensaios sobre o "poder institucional". São Paulo: Hucitec, 1976.

. "Introdução". In.: Lênin: Política. São Paulo: Ática, 1978.

. A condição de sociólogo. São Paulo: Hucitec, 1978.

Queiroz Editor, 1979.

. Da guerrilha ao socialismo: a revolução cubana. São Paulo: T. A.

Hucitec, 1979.

. Apontamentos sobre a "teoria do autoritarismo". São Paulo:

1980.

- Movimento socialista e partidos políticos. São Paulo: Hucitec,

Paulo: Hucitec, 1980.

. Brasil: em compasso de espera. Pequenos escritos políticos. São . A natureza sociológica da Sociologia. São Paulo: Ática, 1980.

. O que é revolução? São Paulo: Brasiliense, 1981.

. Poder e contra-poder na América Latina. Rio de Janeiro: Zahar,

1981.

. A ditadura em questão. São Paulo: T. A. Queiroz Editor, 1982. 
1983.

. "Introdução". In.: K. Marx - F. Engels: História. São Paulo: Ática,

. "Marx: revolução e luta de classes". In.: (org. COGGIOLA, Osvaldo). Em Busca do Socialismo: últimos escritos \& outros textos. São Paulo: Xamã, 1995.

. "Entrevista concedida a José Albertino Rodrigues, UFSCar". (setembro/outubro, 1983). In.: Cientistas do Brasil. Depoimentos. Edição comemorativa dos 50 anos da SBPC, 1998.

. "A pessoa e o político". Entrevista concedida a J. Chasin; Helieth Saffioti, Paulo Douglas Barsotti, Narciso J. Rodrigues Jr., Marilena G.S. Pottes, Ester Vaisman e Paulo Edgar Rezende. In.: Nova Escrita Ensaio, 1981, n. 8.

. Depoimento à Língua e Literatura. Revista dos Departamentos de Letras da Faculdade de Filosofia, Letras e Ciências Humanas da Universidade de São Paulo. São Paulo: Ano X, v. 10-13. 1981-1984.

. A questão da USP. São Paulo: Brasiliense, 1984.

. Nova República? Rio de Janeiro: Zahar, 1986.

. Que tipo de República? São Paulo: Brasiliense, 1986.

. "Florestan Fernandes, história e histórias". Depoimento a Alfredo Bosi, Carlos Guilherme Mota e Gabriel Cohn. In.: Novos Estudos, n. 42. São Paulo, julho 1995.

\section{Entrevistas realizadas para este trabalho.}

Miguel Chaia em 25/05/2006.

Maria Aina Tereza Sadek em 16/06/2006.

\section{Outros. ${ }^{584}$}

FREITAG, Bárbara. "Florestan Fernandes por ele mesmo". (Correspondência com Bárbara Freitag) In.: Estudos Avançados, n. 26, v. 10. São Paulo, janeiro/abril, 1996.

CANDIDO, Antonio. "Plataforma da nova geração". In.: Textos de intervenção. São Paulo: Duas Cidades/Editora 34, 2002.

CARDOSO, Fernando Henrique. Empresário industrial e desenvolvimento econômico no Brasil. São Paulo: Difel, 2ª ed., 1972.

\footnotetext{
${ }^{584}$ Esse trabalho privilegia o contexto da concepção de textos seminais para o meio intelectual paulista. Por isso, são elencados como fontes.
} 
CHAUÍ, Marilena. Cultura e democracia. O discurso competente e outras falas. São Paulo: Moderna, 1981.

COMISSÃO EDITORIAL. "Apresentação". Debate e crítica. Revista semestral de ciências sociais, n. 1. São Paulo: Hucitec, julho, 1973.

COUTINHO, Carlos Nelson. A democracia como valor universal e outros ensaios. Rio de Janeiro: Salamandra, 1984.

DECCA, Edgar de. 1930. O silêncio dos vencidos. São Paulo: Brasiliense, $7^{\mathrm{a}}$ ed., 1997.

DURHAM, Eunice Ribeiro (relatora). O livro negro da USP. O controle ideológico na universidade. São Paulo: ADUSP, 1978.

Encontros com a civilização brasileira, n. 4. Rio de Janeiro, outubro, 1978.

FAUSTO, Boris. A revolução de 30. História e historiografia. São Paulo: Brasiliense, 1978.

LAMBERT, Jacques. Os dois Brasis. Rio de Janeiro: CBPE/INEP/MEC, 1959.

LÊNIN, Vladimir Ilich. Que fazer? São Paulo: Hucitec, 1978. (Prefácio de Florestan Fernandes)

Florestan Fernandes) . O Estado e a revolução. São Paulo: Hucitec, 1978. (Prefácio de

SANTOS, Maria Cecília L. (org.) Maria Antonia: uma rua na contramão. São Paulo: Nobel, 1988.

TOLEDO, Caio Navarro de. ISEB: fábrica de ideologias. São Paulo: Ática, 1978.

WEFFORT, Francisco C. O populismo na política brasileira. Rio de Janeiro: Paz e Terra, 1978.

ZENTENO, Raul Benitez (org.) As classes sociais na América Latina. Problemas de conceituação. Rio de Janeiro: Paz e Terra, 1977.

\section{Bibliografia geral.}

ANDERSON, Perry. Considerações sobre o marxismo ocidental. Nas trilhas do materialismo histórico. São Paulo: Boitempo, 2004. (Tradução de Isa Tavares).

ALMEIDA, Maria Hermínia. Tomando partido, formando opinião. Cientistas sociais, imprensa e política. São Paulo: Sumaré, 1992.

; WEIS, Luiz. "Carro-zero e pau-de-arara: o cotidiano da oposição de classe média ao regime militar". In. SCHWARCZ, Lilia Moritz (org.). História da vida privada no Brasil: contrastes da intimidade contemporânea, v. 4. São Paulo: Companhia das Letras, 1998. 
Paulo: Brasiliense, 1984.

; SORJ, Bernardo. Sociedade e política no Brasil pós-64. São

ALVES, Maria Helena Moreira. Estado e oposição no Brasil 1964/1984. Petrópolis: Vozes, 1984.

ARRUDA, Maria Arminda do Nascimento. Metrópole e cultura. São Paulo no meio do século XX. Bauru: Edusc, 2001.

" "Arremate de uma reflexão: A revolução burguesa

no Brasil de Florestan Fernandes”. Revista USP, n. 29. São Paulo, março/maio, 1996.

; GARCIA, Sylvia Gemignani. Florestan

Fernandes, mestre da sociologia moderna. Brasília: Paralelo 15/Capes, 2003.

BARÃO, Carlos Alberto. "A influência da revolução cubana sobre a esquerda brasileira nos anos 60". MORAES, João Quartim de e REIS FILHO, Daniel Araão (orgs.). História do marxismo no Brasil. O impacto das revoluções, v.I. Campinas: Unicamp, 2003.

BASTOS, Elide Rugai; RIDENTI Marcelo e ROLLAND, Denis (orgs.). Intelectuais: sociedade e política, Brasil-França. São Paulo: Cortez, 2003.

; RÊGO, Walquíria D. Leão (orgs.) Intelectuais e política. A moralidade do compromisso. São Paulo: Olho d'água, 1999.

BENJAMIM, Walter. "O autor como produtor". In.: Obras escolhidas. Magia e técnica, arte e política: ensaios sobre literatura e história da cultura. São Paulo: Brasiliense, 1985. (Tradução de Sérgio Paulo Rouanet).

BOBBIO, Norberto. Os intelectuais e o poder: dúvidas e opções dos homens de cultura na sociedade contemporânea. São Paulo: Unesp, 1997. (Tradução de Marco Aurélio Nogueira).

BOTTOMORE, Tom. Críticos da sociedade. O pensamento radical na América do Norte. Rio de Janeiro: Zahar, 1970.

(Tradução de Waltensir Dutra).

.Dicionário do pensamento marxista. Rio de Janeiro: Zahar, 1988.

BOSI, Alfredo. "Um testemunho do presente". (Prefácio). In.: MOTA, Carlos Guilherme. Ideologia da cultura brasileira (1933-1974). Pontos de partida para uma revisão histórica. São Paulo: Ática, 1977.

BOURDIEU, Pierre. "The role of intellectuals in the modern world". Telos, n. 81. Nova York, 1989.

(Tradução de Sérgio Miceli et al.).

- A economia das trocas simbólicas. São Paulo: Perspectiva, 2003. 
. "O campo científico". In. ORTIZ, R. (org.). Pierre Bourdieu: Sociologia. São Paulo: Ática, 1983. (Tradução de Paula Montero e Alicia Auzmendi).

CANDIDO, Antonio. Lembrando Florestan Fernandes. São Paulo: s.n., 1996.

CASTAÑEDA, Jorge G. Utopia desarmada: intrigas, dilemas e promessas da esquerda latino-americana. São Paulo: Companhia das Letras, 1994. (Tradução de Eric Nepomuceno. Original espanhol)

CARDOSO, Miriam Limoeiro. Para uma história da sociologia no Brasil: a obra sociológica de Florestan Fernandes. Algumas questões preliminares. Coleção documentos, Série Teoria Política 8, Instituto de Estudos Avançados, USP, maio de 1995.

Avançados, n.26, v. 10. São Paulo, janeiro/abril, 1996.

"Florestan: a criação de uma problemática". Estudos

.Capitalismo dependente, autocracia burguesa e revolução social em Florestan Fernandes. Coleção Documentos n. 18, Série História Cultural 6, Instituto de Estudos Avançados, USP, julho, 1997.

. "O pensamento crítico radical de Florestan Fernandes." Revista Margem Esquerda, Ensaios Marxistas, n. 6. São Paulo, setembro, 2005.

CAVALCANTI, Maria Laura Viveiros de Castro; PAIXÃO, Luis Rodolfo da. "Traçando fronteiras: Florestan Fernandes e a marginalização do folclore". Estudos Históricos. Rio de Janeiro, 1990.

CERQUEIRA, Laurez. Florestan Fernandes: vida e obra. São Paulo: Expressão Popular, 2005.

CHARTIER, Roger. "Por uma sociologia histórica das práticas culturais". In.: A história cultural. Entre práticas e representações. Lisboa/Rio de Janeiro: Difel/Bertrand Brasil, 1990. (Tradução de Maria Manuela Galhardo).

COHN, Gabriel. Crítica e resignação. Fundamentos da sociologia de Max Weber. São Paulo: T. A. Queiroz, 1979.

Paulo: Ática, 1979.

"Introdução". In.: COHN, Gabriel (org.). Max Weber: Sociologia. São

"Padrões e dilemas: o pensamento de Florestan Fernandes". In.: ANTUNES, Ricardo; MORAES, Reginaldo; FERRANTE, Vera (orgs.). Inteligência brasileira. São Paulo: Brasiliense, 1986.

. "Apresentação". In.: "Florestan Fernandes, história e histórias". Depoimento a Alfredo Bosi, Carlos Guilherme Mota e Gabriel Cohn. Novos Estudos, n. 42. São Paulo, Julho, 1995. 
"Florestan Fernandes e o radicalismo plebeu em Sociologia". Estudos avançados, n. 55. São Paulo, novembro, 2005.

COSTA, Emilia Viotti da. “A dialética invertida". Revista Brasileira de História, v. 14, n. 27. São Paulo: ANPUH/Marco Zero, 1994.

COUTO, Ronaldo da Costa. História indiscreta da ditadura e da abertura. Rio de Janeiro: Record, 1998.

DEL ROIO, Marcos. "A teoria da revolução brasileira: tentativa de particularização de uma revolução burguesa em processo". In.: MORAES, João Quartim de e DEL ROIO, Marcos. História do marxismo no Brasil. Visões do Brasil, v. IV. Campinas: Unicamp, 2000.

D'INCAO, Maria Ângela (org.). O saber militante. Ensaios sobre Florestan Fernandes. São Paulo: Unesp, 1987.

DÓRIA, Carlos Alberto. "O dual, o feudal e o etapismo na teoria da revolução brasileira". In.: MORAES, João Quartim de. (org.). História do marxismo no Brasil. Teorias e interpretações, v. III. Campinas: Unicamp, 1998.

DREIFUSS, René Armand. 1964: A conquista do Estado. Ação política, poder e golpe de classe. Rio de Janeiro: Vozes, 1987.

FERNANDES, Heloísa (org.). "Mills, o sociólogo-artesão". In.: FERNANDES, Heloísa. Charles Wright Mills: Sociologia. São Paulo: Ática, 1985.

"Prefácio". In.: FERNANDES, Florestan. Apontamentos Sobre a "teoria do Autoritarismo". São Paulo: Hucitec, 1979.

. "Florestan Fernandes, Universidade e MST". In.: Caros Amigos, n. 96. São Paulo: Casa Amarela, março, 2005. . "Chaves do exílio e portas da esperança” São Paulo: S.1., 2005.

GARCIA, Marco Aurélio. "Reforma e revolução/ reforma ou revolução. Discussão de um paradigma". Revista Brasileira de História, v. 10, n. 2. São Paulo: ANPUH/CNPq/FAPESP, 1991.

GARCIA, Sylvia Gemignani. Destino ímpar. Sobre a formação de Florestan Fernandes. São Paulo: Editora 34, 2002.

GRAMSCI, Antonio. Os intelectuais e a organização da cultura. Rio de Janeiro: Civilização Brasileira, 1979.

GORENDER, Jacob. Combate nas trevas. São Paulo: Ática, 1990.

HOBSBAWM, Eric. A era dos extremos. São Paulo: Companhia das Letras, 1995. 
. Revolucionários. Rio de Janeiro: Paz e Terra, $3^{\text {a }}$ ed., 2003. (Tradução de João C. Vitor Garcia e Adelângela Saggioro Garcia).

IANNI, Octavio. "Introdução". In.: Florestan Fernandes: Sociologia. (Coleção Grandes Cientistas Sociais). São Paulo: Ática, 1986. . Sociologia da Sociologia. O pensamento sociológico brasileiro. São Paulo:

Ática, 1989. . A idéia do Brasil moderno. São Paulo: Brasiliense, 1992.

JACOBY, Russel. Os últimos intelectuais: a cultura americana na era da academia. São Paulo: Trajetória Cultural/Edusp, 1990. (Tradução de Magda Lopes)

KECK, Margareth. PT - a lógica da diferença. O Partido dos Trabalhadores na construção da democracia brasileira. São Paulo: Ática, 1991. (Tradução de Maria Lucia Pontes)

KRISCHKE, Paulo (org.). Brasil: do “milagre” à “abertura”. São Paulo: Cortez, 1982.

KUCINSKI, Bernardo. O fim da ditadura militar. São Paulo: Contexto, 2001.

LAHUERTA, Milton. Intelectuais e transição: entre a política e a profissão. São Paulo: USP, Departamento de Ciência Política, tese de doutorado, 1999.

LOPES, Marcos Antônio (org.). Grandes nomes da história intelectual. São Paulo: Contexto, 2003.

LOUREIRO, Isabel Maria, et al. Liberalismo e socialismo: velhos e novos paradigmas. São Paulo: Unesp, 1995.

LOWENTHAL, David. "Como conhecemos o passado". Projeto História. Trabalhos da Memória. Revista do Programa de Estudos Pós-Graduados em História e do Departamento de História. PUC-SP. São Paulo, n. 17, novembro, 1998. (Tradução de Lúcia Haddad).

LÖWY, Michael. Para uma sociologia dos intelectuais revolucionários. A evolução política de Lucács. (1909-1929). São Paulo: Livraria Editora Ciências Humanas, 1979.

. As aventuras de Karl Marx contra o Barão de Münchhausen: Marxismo e positivismo na Sociologia do conhecimento. São Paulo: Cortez, 1994.

. "Pontos de referência para uma história do marxismo na América Latina". In.: LÖWY, Michael. O marxismo na América Latina. Uma antologia de 1909 aos dias atuais. São Paulo: Perseu Abramo, 1999.

LUKÁCS, Georg. História e consciência de classe. Rio de Janeiro: Elfos, 1989. (Tradução de Telma Costa). 
MANNHEIM, Karl. Ideologia e utopia. Rio de Janeiro: Zahar, 1968. (Tradução da edição inglesa de 1960).

de Roberto Gambini).

Sociologia da Cultura. São Paulo: Edusp/Perspectiva, 1974. (Tradução

MARTINEZ, Paulo Henrique (org.). Florestan ou o sentido das coisas. São Paulo: Boitempo Editorial, 1998.

. "Prefácio". FERNANDES, Florestan. Pensamento e ação: o

PT e os rumos do socialismo. São Paulo: Globo, $2^{\mathrm{a}}$ ed., 2006.

MARTINS, José de Souza. Florestan. Sociologia e consciência social no Brasil. São Paulo: Edusp, 1998.

"Vida e história na sociologia de Florestan Fernandes". Revista

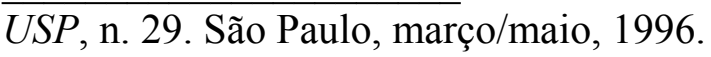

"A morte de Florestan e a morte da memória". Estudos Avançados, n.26, v. 10. São Paulo, janeiro/abril, 1996.

"Prefácio". In.: A revolução burguesa no Brasil. São Paulo:

Globo, $5^{\text {a }}$ ed., 2006.

MARTINS, Tatiana Gomes. Raízes da sociologia brasileira: Florestan Fernandes e a questão do intelectual. Campinas: Unicamp, Instituto de Filosofia e Ciências Humanas, dissertação de mestrado, 2002.

MARTINS FILHO, João Roberto. "Um homem e seu tempo". In.: Florestan Fernandes: a força do argumento. São Paulo: Edufscar, 1997.

MAXIMO, Antonio Carlos. Os intelectuais e a educação das massas. O retrato de uma tormenta. Campinas: Autores Associados, 2000.

MELLO, João Manuel Cardoso, e NOVAIS, Fernando. "Capitalismo tardio e sociabilidade moderna". In. SCHWARCZ, Lilia Moritz (org.). História da vida privada no Brasil: contrastes da intimidade contemporânea, v.4. São Paulo: Companhia das Letras, 1998.

MELO, Carlos Alberto Furtado de. Imprensa e democracia: a transformação da Folha de S. Paulo e a criação do Partido dos Trabalhadores. São Paulo: PUC-SP, Departamento de Ciências Sociais, dissertação de mestrado, 1996.

MENEGUELLO, Rachel. PT: a formação de um partido, 1979-1982. Rio de Janeiro: Paz e Terra, 1989.

MICELI, Sérgio (org.). História das Ciências Sociais no Brasil, v.2. São Paulo: Sumaré, 1995. 
História das Ciências Sociais no Brasil, v. 1. São Paulo: Sumaré,

2001.

MORAES, João Quartim de. "O programa nacional-democrático: fundamentos e permanência". In.: MORAES, João Quartim de e DEL ROIO, Marcos. História do marxismo no Brasil. Visões do Brasil, v. IV. Campinas: Unicamp, 2000.

MOTA, Carlos Guilherme. Ideologia da cultura brasileira (1933-1974). Pontos de partida para uma revisão histórica. São Paulo: Ática, 1977.

MOTA, Lourenço Dantas (org.). Introdução ao Brasil. Um banquete no trópico, v. 1 e v.2. São Paulo: Senac, 1999.

NETTO, José Paulo. "Em busca da contemporaneidade perdida: a esquerda brasileira pós-64". In. MOTA, Carlos Guilherme (org.). Viagem incompleta. A experiência brasileira (1500200). A grande transação. São Paulo, Sesc/Senac, 2000.

NOGUEIRA, Marco Aurélio. "Gramsci, a questão democrática e a esquerda no Brasil". In.: COUTINHO, Carlos Nelson e NOGUEIRA, Marco Aurélio (orgs.). Gramsci e a América Latina. São Paulo; Paz e Terra, 1988.

NOVAIS, Fernando. Aproximações: ensaios de história e historiografia. São Paulo: Cosac Naify, 2005.

OLIVEIRA, Lucia Lippi. A sociologia do Guerreiro. Rio de Janeiro: Ed.da UFRJ, 1995.

ORTIZ, Renato. "Notas sobre as ciências sociais no Brasil". Novos Estudos, n.27. São Paulo, julho, 1990.

. A moderna tradição brasileira. Cultura brasileira e indústria cultural. São Paulo: Brasiliense, $5^{\text {a }}$ ed., 2001.

PAIVA, Carlos Águedo N. Capitalismo dependente e (contra) revolução burguesa no Brasil: um estudo sobre a obra de Florestan Fernandes. Campinas: Unicamp, Instituto de Economia, dissertação de mestrado, 1991.

Avançados, n. 30, v. 11. São Paulo, maio, 1997.

PÉCAUT, Daniel. Os intelectuais e a política no Brasil. Entre o povo e a nação. São Paulo: Ática, 1990. (Tradução de Maria Júlia Goldwasser)

POLANYI, Karl. A grande transformação: as origens da nossa época. Rio de Janeiro: Campus, 1980. (Tradução de Fanny Wrobel)

PULICI, Carolina. De como o sociólogo deve praticar o seu ofício: as cátedras de sociologia da USP entre 1954 e 1969. São Paulo: USP, Departamento de Ciência Política, dissertação de mestrado, 2004. 
REIS FILHO, Daniel Araão. (org.) Intelectuais, história e politica (séculos XIX e XX). Rio de Janeiro: 7 letras, 2000.

"O colapso do colapso do populismo". In.: FERREIRA, Jorge (org.). O populismo e sua história. Debate e crítica. Rio de Janeiro: Civilização Brasileira, 2001.

; RIDENTI, Marcelo e MOTTA, Rodrigo de Sá. $O$ golpe e a ditadura militar 40 anos depois (1964-2004). Bauru: Edusc, 2004.

RÉMOND, René (org.). Por uma história politica. São Paulo: FGV, $2^{\mathrm{a}}$ ed., 2003. (Tradução de Dora Rocha).

RIDENTI, Marcelo. O fantasma da revolução brasileira. São Paulo: Unesp, 1993.

."Os trotskistas brasileiros e suas organizações políticas (1930-1966). In.: REIS FILHO, Daniel Araão e RIDENTI, Marcelo. História do marxismo no Brasil. Partidos e organizações dos anos 20 e 60, v. V. Campinas: Unicamp, 2002.

RINGER, Fritz K. O declínio dos mandarins alemães. São Paulo: Edusp, 2000. (Tradução de Dinah de Abreu Azevedo).

ROMÃO, Wagner de Melo. A experiência do Cesit: sociologia e política acadêmica nos anos 1960. São Paulo: USP, Departamento de Sociologia, dissertação de mestrado, 2003.

ROSANVALLON, Pierre. "Por uma história conceitual do político". Revista Brasileira de História, v.15, n.30. São Paulo, 1995. (Tradução de Paulo Henrique Martinez).

RUBIM, Antônio Albino Canelas. "Marxismo, cultura e intelectuais no Brasil". In.: MORAES, João Quartim de. (org.). História do marxismo no Brasil. Teorias. Interpretações, v. III. Campinas: Unicamp, 1998.

SALLUM JR. Basílio. "Notas sobre o surgimento da Sociologia Política em São Paulo". Política \& sociedade. Revista de sociologia política, n. 01. Florianópolis: Cidade futura, 2002.

SANTOS, Boaventura de Souza. "Florestan: um sociólogo comprometido com seu tempo". Estudos Avançados, n.26, v. 10. São Paulo, janeiro/abril, 1996.

SANTOS, Raimundo. "Crise e pensamento moderno no PCB dos anos 50". In.: MORAES, João Quartim de e REIS FILHO, Daniel Araão. (orgs.). História do marxismo no Brasil. O impacto das revoluções, v.I. Campinas: Unicamp, 2003.

SARTRE, Jean-Paul. Em defesa dos intelectuais. São Paulo: Ática, 1994. (Tradução de Sergio Goes de Paula. Apresentação de Francisco C. Weffort).

SCHWARZ, Roberto. O pai de família e outros estudos. São Paulo: Paz e Terra, 1978.

1998. “Um seminário de Marx”. Novos Estudos, n. 50. São Paulo, março, 
SECCO, Lincoln Ferreira. A recepção das idéias de Gramsci no Brasil. São Paulo: USP, Departamento de História, dissertação de mestrado, 1998.

- "Marxismo e democracia. O debate estratégico de Marx aos austromarxistas". In.: SECCO, Lincoln e SANTIAGO, Carlos. Um olhar que persiste. Ensaios críticos sobre o capitalismo e o socialismo. São Paulo: Anita Garibaldi, 1997.

SEREZA, Haroldo Ceravolo. Florestan: a inteligência militante. São Paulo: Boitempo, 2005.

SIRINELLI, Jean-François. "A geração". In.: FERREIRA, Marieta de Moraes e AMADO, Janaína. Usos e abusos da história oral. Rio de Janeiro: FGV, 1996. (Tradução de Luiz Alberto Monjardim et al.)

SOARES, Eliane Veras. Florestan Fernandes: o militante solitário. São Paulo: Cortez, 1997.

SORJ, Bernardo. A construção intelectual do Brasil contemporâneo. Da resistência à ditadura ao governo FHC. Rio de Janeiro: Jorge Zahar, 2001.

STEPAN, Alfred. Democratizando o Brasil. Rio de Janeiro: Paz Terra, 1988.

TOLEDO, Caio Navarro de. (org.) 1964. Visões críticas do golpe. Campinas: Unicamp, 1997.

."Intelectuais do Iseb, esquerda e marxismo". In.: MORAES, João Quartim de. (org.). História do marxismo no Brasil. Teorias. Interpretações, v. III. Campinas: Unicamp, 1998.

"A modernidade democrática da esquerda: adeus à revolução?".

Crítica marxista, n. 1. São Paulo: Brasiliense, 1994.

VIANNA, Luiz Werneck. "A institucionalização das ciências sociais e a reforma social: do pensamento social à agenda americana de pesquisa". In. A revolução passiva. Iberismo e americanismo no Brasil. Rio de Janeiro: Revan, 1997.

53. São Paulo, março, 1999.

"Weber e a interpretação do Brasil". Novos Estudos CEBRAP, n.

VIEIRA, Evaldo. "Brasil: do golpe de 1964 à redemocratização". In. MOTA, Carlos Guilherme (org.). Viagem Incompleta. A experiência brasileira (1500-200). A grande transação. São Paulo: Sesc/Senac, 2000.

VOUGA, Claudio. "Evocações na contramão". Revista USP, n. 29. São Paulo, março/maio, 1996.

WEBER, Max. Ciência e Política. Duas vocações. São Paulo: Cultrix, 1967. (Tradução de Leônidas Hegenberg e Octany Silveira da Mota).

. "A objetividade do conhecimento em Ciências Sociais". In.: COHN, Gabriel (org.). Max Weber: Sociologia. São Paulo: Ática, 1979. 
WINOCK, Michel. O século dos intelectuais. Rio de Janeiro: Bertrand Brasil, 2000. (Tradução de Eloá Jacobina).

\section{Bibliotecas e arquivos consultados.}

Arquivo Público do Estado de São Paulo

Biblioteca Florestan Fernandes. Faculdade de Filosofia, Letras e Ciências Humanas Universidade de São Paulo (FFLCH-USP).

Seção de Recursos Humanos - Administração da Faculdade de Filosofia, Letras e Ciências Humanas - Universidade de São Paulo (FFLCH-USP).

Biblioteca Comunitária da Universidade Federal de São Carlos (UFSCar) - Coleções Especiais - Florestan Fernandes.

Biblioteca Nadir Gouvêa Kfouri. Pontifícia Universidade Católica de São Paulo (PUC-SP) 